\author{
UNIVERSIDADE DE SÃO PAULO \\ Faculdade de Economia, Administração e Contabilidade \\ Departamento de Administração
}

\title{
GOVERNANÇA CORPORATIVA, DESEMPENHO E VALOR DA EMPRESA NO BRASIL
}

Alexandre Di Miceli da Silveira

Orientador: Prof. Dr. Rubens Famá

São Paulo, Outubro de 2002 


\section{UNIVERSIDADE DE SÃO PAULO \\ Faculdade de Economia, Administração e Contabilidade \\ Departamento de Administração}

\section{GOVERNANÇA CORPORATIVA, DESEMPENHO E VALOR DA EMPRESA NO BRASIL}

Alexandre Di Miceli da Silveira

Orientador: Prof. Dr. Rubens Famá

Dissertação a ser apresentada ao Departamento de Administração da Faculdade de Economia, Administração e Contabilidade da Universidade de São Paulo como requisito parcial para a obtenção do título de Mestre em Administração.

São Paulo, Outubro de 2002 


\section{REITOR DA UNIVERSIDADE DE SÃo PAULO}

Prof. Dr. Adolpho Jose Melfi

\section{DIRETOR DA FACULDADE DE ECONOMIA, ADMINISTRAÇÃo E CONTABILIDADE}

Prof.a. Dra. Maria Tereza Leme Fleury

\section{CHEFE DO D EPARTAMENTO DE ADMINISTRAÇÃO}

Prof. Dr. Eduardo Pinheiro Gondin de Vasconcellos

CoOrdenador do Programa de Pós-GraduaÇão em Administração

Prof. Dr. Isak Kruglianskas 
Ao Prof. Dr. Cléber Aquino, pelo incentivo e orientação,

Ofereço esta dissertação

Ao meu pai,

Prof. Dr. Joaquim Albenísio G. da Silveira, pelo exemplo de vida, pela orientação e por ser a fonte de toda minha motivação,

Dedico 


\section{Agradecimentos}

Ao Prof. Dr. Rubens Famá, com quem tive a honra de aprender nas disciplinas da Pós-Graduação e desenvolver artigos em conjunto, pela orientação durante todo o trabalho e pelo exemplo de dedicação acadêmica, amizade e cavalheirismo.

Ao Prof. Dr. José Roberto Securato, membro da banca, pelas oportunidades oferecidas para meu desenvolvimento desde o início do curso, pelo aprendizado nas suas disciplinas da Pós-Graduação, pelas críticas e sugestões muito valiosas para o aprimoramento desta dissertação e principalmente pelo exemplo de dinamismo e entusiasmo para desenvolver a área de finanças da nossa faculdade.

Ao Prof. Dr. Luiz Nelson Guedes de Carvalho, membro da banca, pela minuciosa revisão desta dissertação e pelas valiosas críticas e contribuições que engrandeceram este trabalho.

Ao Prof. Dr. Almir Ferreira de Sousa, com quem tive a honra de escrever artigos em conjunto, pelo aprendizado nas suas disciplinas da Pós-Graduação, pelas oportunidades oferecidas para meu desenvolvimento acadêmico e profissional desde o início do curso e pelo exemplo de dedicação acadêmica e capacidade de ensino.

Ao Prof. Dr. José Roberto Ferreira Savoia, pelo aprendizado, amizade e oportunidades oferecidas para meu desenvolvimento profissional.

Ao Professor, e em breve Doutor, Lucas Ayres Barros, pelo apoio na definição, aplicação e análise da estatística desta dissertação e pelas revisões e discussões sobre o conteúdo teórico do trabalho, mas principalmente pela forte amizade, pela convivência e pelo exemplo de dedicação acadêmica e filosofia de vida.

Aos professores do Departamento de Administração da FEA-USP, pelo aprendizado. 
Ao amigo e doutorando André Luiz Oda, pelo aprendizado nos projetos desenvolvidos ao longo do curso, pelas oportunidades oferecidas, pela orientação profissional e, especialmente, pelo exemplo de perseverança e conciliação das ativid ades acadêmicas e profissionais.

Ao Grupo Marquise, cujo Programa de Trainees propiciou desenvolver minha formação pessoal, ampliar meus horizontes e fazer amigos duradouros.

À Arthur D Little, cuja possibilidade de desenvolver projetos sobre o tema ampliou meu conhecimento sobre o assunto, especialmente ao colega Celso González, pelo interesse sobre o estudo e pela compreensão, me possibilitando conciliar as atividades.

Aos amigos Josefina Moraes Arraut, Rodrigo Takashi Okimura, Elton Takimoto e Daniel Mbta de Carvalho, pelo apoio durante o curso de mestrado e pelo convívio.

Por fim, à minha família: ao meu pai, pelo amor e incentivo, à minha mãe, pelo amor e pelas orações, e aos meus irmãos Bruno e Thaís, pela motivação, carinho e afeto. 


\section{Resumo}

A governança corporativa visa aumentar a probabilidade dos fornecedores de recursos garantirem para si o retorno sobre seu investimento, por meio de um conjunto de mecanismos no qual se inclui o Conselho de Administração. O tema possui importância crescente, por ser bem difundida a hipótese de que a estrutura de governança afeta o valor da empresa. A questão é descobrir se existe uma estrutura de governança corporativa "melhor" ou "ideal". Vários códigos de governança foram elaborados com este intuito. No Brasil, destacam-se os códigos do Instituto Brasileiro de Governança Corporativa (IBGC) e da Comissão de Valores Mobiliários (CVM). Esta dissertação investiga se a estrutura de governança corporativa foi relevante para as companhias abertas brasileiras de 1998 a 2000 e se as companhias adequadas às recomendações do IBGC e da CVM alcançaram maior valor de mercado ou melhor desempenho. Três variáveis de governança foram consideradas: separação dos cargos de diretor executivo e presidente do conselho (DE), tamanho do conselho (TOT) e independência do conselho (INDEP). Utilizourse uma regressão múltipla do tipo seção transversal entre as variáveis dependentes de valor e desempenho e as variáveis independentes de governança corporativa. A variável diretor executivo como presidente do conselho (DE) apresentou os resultados mais importantes, com forte evidência de que, em média, as empresas que têm pessoas distintas ocupando os cargos de diretor executivo e presidente do conselho são mais valorizadas pelo mercado. A variável tamanho do conselho (TOT) apresentou uma relação certamente não linear, sugerindo que as empresas com um número intermediário de conselheiros alcançam melhor desempenho. A variável independência do conselho (INDEP) não apresentou relação significativa contra as variáveis de valor e desempenho. 


\section{Abstract \\ Corporate Governance, Performance and Firm Value in Brazil}

Corporate governance seeks to increase the probability that suppliers of financial resources will assure themselves the return on their investment through a set of mechanisms including the Board of Directors. The subject has growing importance, because it is well spread the hypothesis that corporate governance affects firm value. The question is to find out if there is a "better" or "ideal" corporate governance structure for the firm. Several corporate governance codes were prepared with this purpose. In Brazil, we highlight the IBGC (Brazilian Institute of Corporate Governance) and the CVM (Brazilian Securities and Exchange Commission) codes. This dissertation investigates if the corporate governance structure was important to Brazilian listed companies from 1998 to 2000 and if the companies more adjusted to the IBGC and CVM recommendations achieved higher market value or superior performance. Three governance variables were considered: the separation of chief executive officer and chairman positions (DE), board size (TOT), and board independence (INDEP). The multiple regression method with cross sectional data was applied between firm value and performance dependent variables and corporate governance independent variables. The variable chief executive officer as chairman (DE) has showed the most important results, with strong evidence that, on average, firms with different people in charge of the chief executive officer and chairman positions have higher market value than the others. The variable board size (TOT) has showed a clear non linear relation, suggesting that firms with an intermediate number of directors achieve superior performance. The variable independence of the board (INDEP) has not showed a significant relation against the variables of value and performance. 


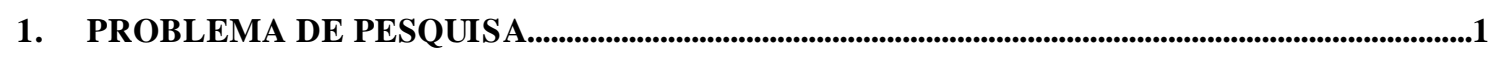

1.1. INTRODUÇ

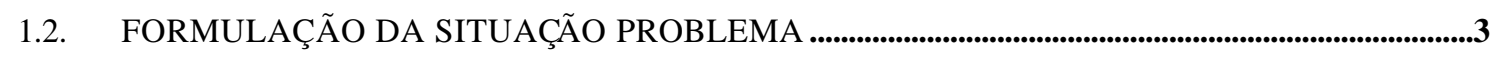

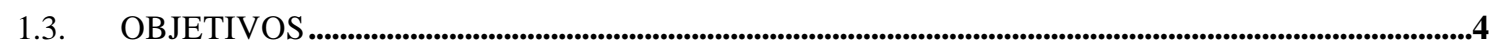

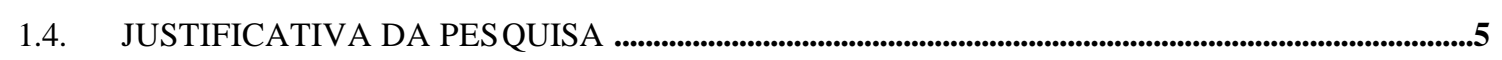

1.5. DELIMITAÇ

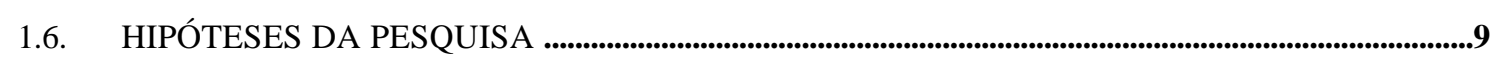

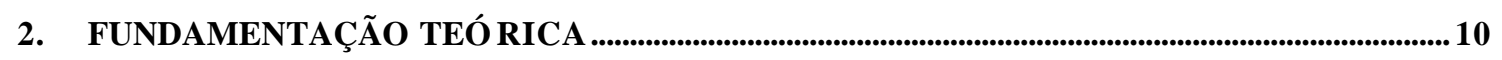

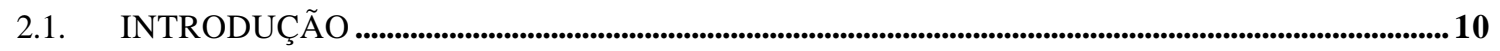

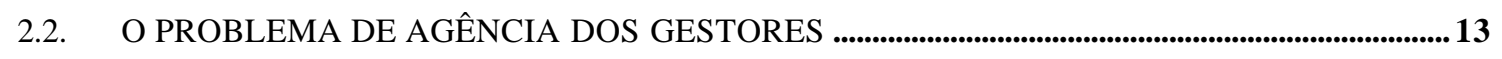

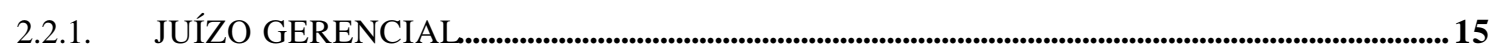

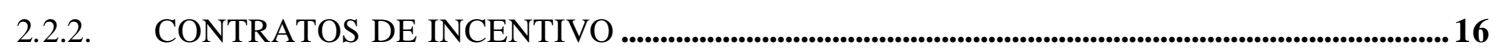

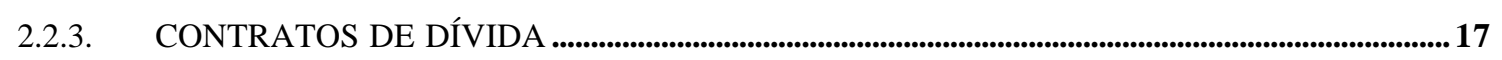

2.3. SISTEMAS DE GOVERNANÇA CORPORATIVA NO MUNDO.............................................................18

2.3.1. A GOVERNANÇA CORPORATIVA NOS ESTADOS UNIDOS ...........................................19

2.3.2. A GOVERNANÇA CORPORATIVA NO REINO UNIDO ........................................................21

2.3.3. A GOVERNANÇA CORPORATIVA NA ALEMANHA .................................................................22

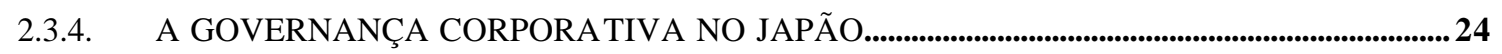

2.3.5. A GOVERNANÇA CORPORATIVA NA FRANÇA ...................................................................26

2.3.6. COMPARAÇÃO ENTRE OS SISTEMAS DE GOVERNANÇA CORPORATIVA ....................27

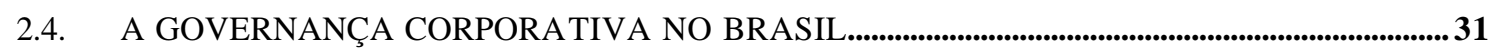

2.5. ABORDAGEM LEGAL PARA A GOVERNANÇA CORPORATIVA ..................................................41

2.6. O PAPEL DOS GRANDES INVESTIDORES ............................................................................................... 44

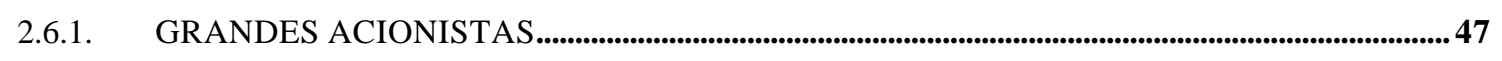

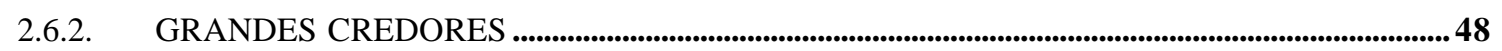

2.7. CONSELHO DE ADMINISTRAÇÃO E SEU PAPEL NA GOVERNANÇA CORPORATIVA 49

2.7.1. COMPOSIÇÃO DO CONSELHO E DESEMPENHO DA EMPRESA ..........................................51

2.7.2. TAMANHO DO CONSELHO E DESEMPENHO DA EMPRESA ....................................................55

2.7.3. CARACTERÍSTICAS DO CONSELHO E A EXECUÇÃO DE SUAS TAREFAS.....................56

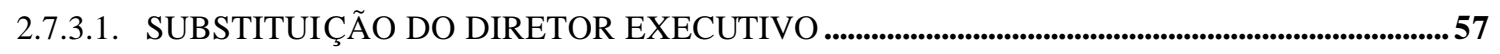

2.7.3.2. RESPOSTA À OFERTA DE AQUISIÇÃ O HOSTIL...................................................................................59

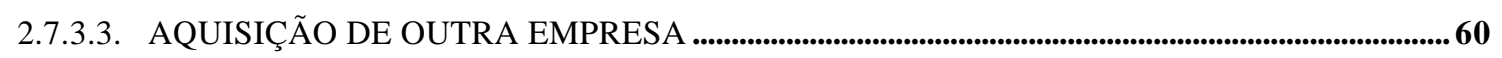

2.7.3.4. REMUNERAÇÃO DOS ALTOS EXECUTIVOS..............................................................................61

2.7.4. A RELAÇÃO ENDÓGENA ENTRE ESTRUTURA DO CONSELHO E DESEMPENHO ....62

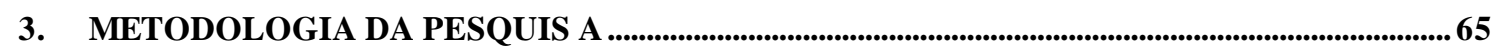

3.1. MÉTODO UTILIZADO, TRATAMENTO ESTATÍSTICO E ANÁLISE DOS DADOS .............. 65

3.2. DEFINIÇÃO TEÓRICA E OPERACIONAL DAS VARIÁVEIS ..................................................68

3.2.1. GOVERNANÇA CORPORATIVA ......................................................................................................69

3.2.2. MELHOR ESTRUTURA DE GOVERNANÇA CORPORATIVA ........................................................70 


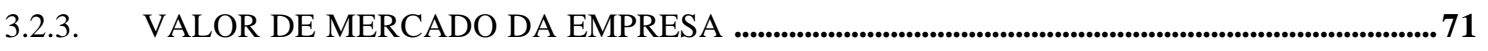

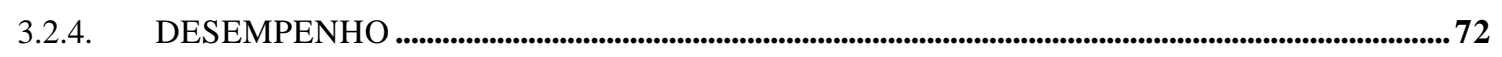

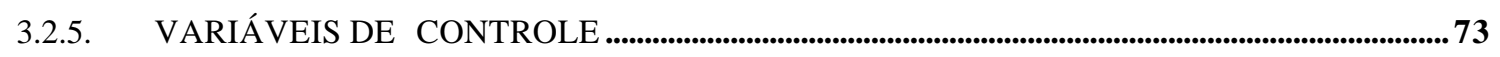

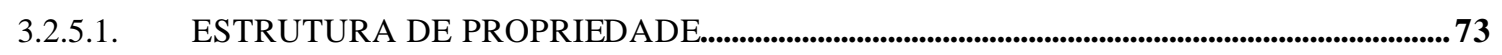

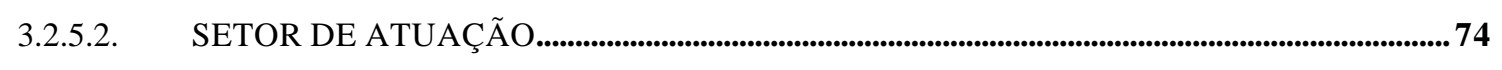

3.3. POPULAÇÃO, AMOSTRAGEM E COLETA DOS DADOS .................................................................75

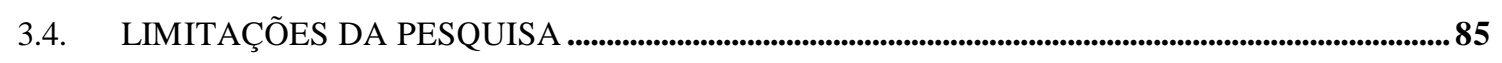

3.4.1. RELAÇÕES DE CAUSALIDADE ENTRE AS VARIÁVEIS E ENDOGENEIDADE.............85

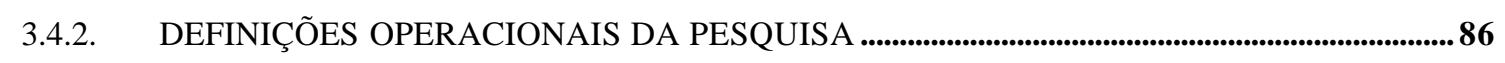

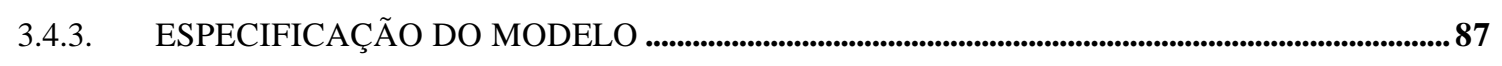

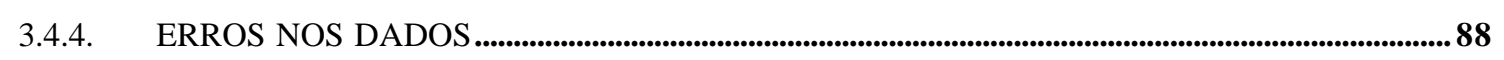

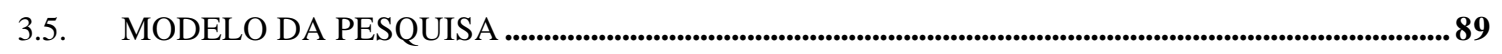

3.5.1. MODELO GERAL DA PESQUISA .......................................................................................................89

3.5.2. MODELO ESQUEMÁTICO DO TESTE DE HIPÓTESES ..........................................................................90

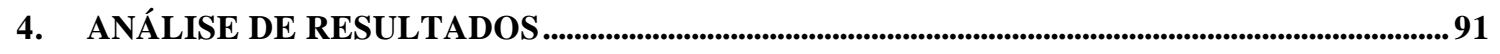

4.1. ESTRUTURA DE GOVERNA NÇA DAS COMPANHIAS A BERTAS BRASILEIRAS..............91

4.2. RESULTADOS DOS TESTES DE HIPÓTESES ..........................................................................................97

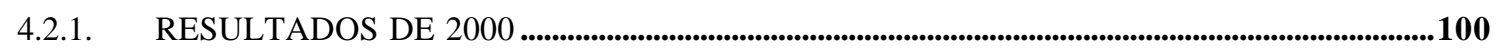

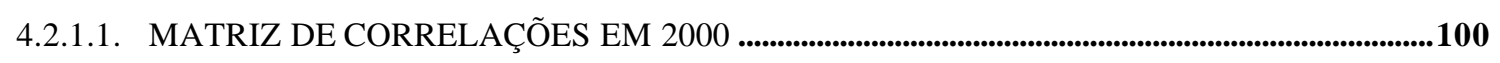

4.2.1.2. RELAÇÃO ENTRE GOVERNANÇA CORPORATIVA E VALOR EM 2000..............................102

4.2.1.3. RELAÇÃO ENTRE GOVERNANÇA CORPORATIVA E DESEMPENHO EM 2000 ...........110

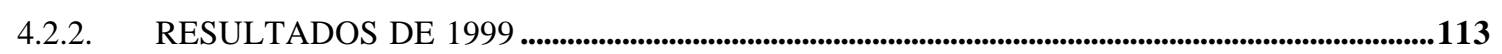

4.2.2.1. MATRIZ DE CORRELAÇÕES EM 1999 ......................................................................................113

4.2.2.2. RELAÇÃO ENTRE GOVERNANÇA CORPORATIVA E VALOR EM 1999.............................115

4.2.2.3. RELAÇÃO ENTRE GOVERNANÇA CORPORATIVA E DESEMPENHO EM 1999 ............117

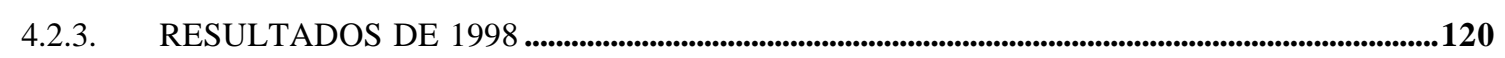

4.2.3.1. MATRIZ DE CORRELAÇÕES EM 1998 ........................................................................................................120

4.2.3.2. RELAÇÃO ENTRE GOVERNANÇA CORPORATIVA E VALOR EM 1998 ............................122

4.2.3.3. RELAÇÃO ENTRE GOVERNANÇA CORPORATIVA E DESEMPENHO EM 1998 ...........125

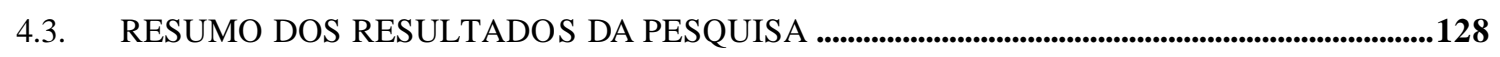

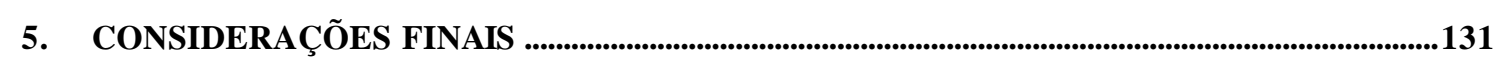

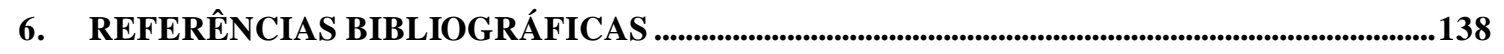

6.1. BIBLIOGRAFIA COMPLEMENTAR ........................................................................................................146 


\section{Lista de Quadros}

QUADRO 1 - CLASSIFICAÇÃO DOS SISTEMAS DE GOVERNANÇA DOS PAÍSES PELAS FONTES DE RECURSOS....28 QUADRO 2 - AVALIAÇÃO DA PROTEÇÃO LEGAL AOS INVESTIDORES DE ACORDO COM A ORIGEM DAS LEIS.. 43 QUADRO 3 - VARIÁVEIS INDEPENDENTES DO ESTUDO: GOVERNANÇA CORPORATIVA ........................................65

QUADRO 4 - VARIÁVEIS DEPENDENTES DO ESTUDO: VALOR DA EMPRESA E DESEMPENHO................................66

QUADRO 5 - VARIÁVEIS DE CONTROLE DO ESTUDO...........................................................................................66

QUADRO 6 - SISTEMAS DE INFORMAÇÕES UTILIZADOS NO ESTUDO_...............................................................

QUADRO 7 - DADOS DE GOVERNANÇA E ESTRUTURA DE PROPRIEDADE DAS EMPRESAS EM 2000 ………….....77

QUADRO 8 - VARIÁVEIS DEPENDENTES DE VALOR CALCULADAS PARA O ANO DE 1998 ..................................83

QUADRO 9 - COMPOSIÇÃO DO CONSELHO DE ADMINISTRAÇÃO DAS EMP RESAS EM 1998 ………………….......91

QUADRO 10 - COMPOSIÇÃO DO CONSELHO DE ADMINISTRAÇÃO DAS EMPRESAS EM 1999...............................91

QUADRO 11 - COMPOSIÇÃO DO CONSELHO DE ADMINISTRAÇÃO DAS EMP RESAS EM 2000 …………………....91

QUADRO 12 - PERCENTUAL DE EMPRESAS COM A MESMA PESSOA OCUPANDO OS CARGOS DE DIRETOR

EXECUTIVO E PRESIDENTE DO CONSELHO .................................................................................................94

QUADRO 13 - PERCENTUAL DE EMPRESAS COM PRESENÇA DE ACORDO DE ACIONISTAS...................................95

QUADRO 14- ESTRUTURA DE PROPRIEDADE DAS EMPRESAS EM 1998 ……………………………………......96

QUADRO 15 - ESTRUTURA DE PROPRIEDADE DAS EMPRESAS EM 1999_.............................................................96

QUADRO 16 - ESTRUTURA DE PROPRIEDADE DAS EMPRESAS EM 2000_.............................................................96

QUADRO 17 - CORRELAÇÕES ENTRE AS VARIÁVEIS DE GOVERNANÇA NO ANO DE 2000 ……..........................100

QUADRO 18 - CORRELAÇÕES ENTRE AS VARIÁVEIS DE GOVERNANÇA, ESTRUTURA DE PROPRIEDADE E

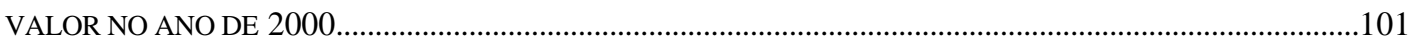

QUADRO 19 - CORRELAÇÕES ENTRE AS VARIÁVEIS DE GOVERNANÇA, ESTRUTURA DE PROPRIEDADE E

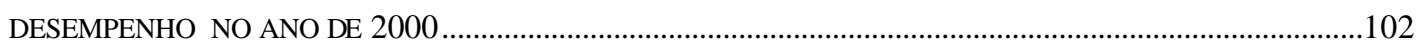

QUADRO 20 - RELAÇÃO ENTRE A VARIÁVEL VALOR DA EMPRESA SOBRE ATIVO TOTAL (FIRMVSAT) E AS VARIÁVEIS DE GOVERNANÇA EM 2000 104

QUADRO21 - RELAÇÃO ENTRE A VARIÁVEL VALOR DA EMPRESA SOBRE ATIVO TOTAL (FIRMVSAT) E AS VARIÁVEIS DE GOVERNANÇA EM 2000 SEM A UTILIZAÇÃO DA ESCALA LOGARÍTMICA P ARA A VARIÁVEL TOT .106

QUADRO 22 - RELAÇÃO ENTRE A VARIÁVEL Q DE TOBIN (Q) E AS VARIÁVEIS DE GOVERNANÇA EM 2000 .108

QUADRO 23 - RELAÇ̃̃o ENTRE A VARIÁVEL Q DE TOBIN (Q) E AS VARIÁVEIS DE GOVERNANÇA EM 2000 SEM A UTILIZAÇÃO DA ESCALA LOGARÍTMICA P ARA A VARIÁVEL TOT .109

QUADRO 24 - RELAÇÃO ENTRE A VARIÁVEL RETORNO SOBRE O ATIVO UTILIZANDO O LUCRO OPERACI ONAL PRÓPRIO (RSAPR) E AS VARIÁVEIS DE GOVERNANÇA EM 2000. . .111

QUADRO 25 - CORRELAÇÕES ENTRE AS VARIÁVEIS DE GOVERNANÇA NO ANO DE 1999 113

QUADRO 26 - CORRELAÇÕES ENTRE AS VARIÁVEIS DE GOVERNANÇA, ESTRUTURA DE PROPRIEDADE E VALOR NO ANO DE 1999.

QUADRO 27 - CORRELAÇÕES ENTRE AS VARIÁVEIS DE GOVERNANÇA, ESTRUTURA DE PROPRIEDADE E DESEMPENHO NO ANO DE 1999 
QUADRO 28 - RELAÇÃO ENTRE A VARIÁVEL Q DE TOBIN (Q) E AS VARIÁVEIS DE GOVERNANÇA EM 1999

QUADRO 29 - RELAÇÃO ENTRE A VARIÁVEL VALOR DA EMPRESA SOBRE ATIVO TOTAL (FIRMVSAT) E AS VARIÁVEIS DE GOVERNANÇA EM 1999

QUADRO 30 - RELAÇÃO ENTRE A VARIÁVEL LUCRO ANTES DOS JUROS, IMPOSTOS, DEPRECIAÇÃO E AMORTIZAÇÃO (EBITSAT) E AS VARIÁVEIS DE GOVERNANÇA EM 1999 ..............................................118

QUADRO 31 - CORRELAÇÕES ENTRE AS VARIÁVEIS DE GOVERNANÇA NO ANO DE 1998 .120

QUADRO 32 - CORRELAÇÕES ENTRE AS VARIÁVEIS DE GOVERNANÇA, ESTRUTURA DE PROPRIEDADE E VALOR NO ANO DE 1998. .120

QUADRO 33 - CORRELAÇÕES ENTRE AS VARIÁVEIS DE GOVERNANÇA, ESTRUTURA DE PROPRIEDADE E DESEMPENHO NO ANO DE 1998

QUADRO 34 - RELAÇÃO ENTRE A VARIÁVEL Q DE TOBIN (Q) E AS VARIÁVEIS DE GOVERNANÇA EM 1998

QUADRO 35 - RELAÇÃO ENTRE A VARIÁVEL VALOR DA EMPRESA SOBRE ATIVO TOTAL (FIRMVSAT) E AS VARIÁVEIS DE GOVERNANÇA EM 1998

QUADRO 36 - RELAÇÃO ENTRE O LUCRO ANTES DOS JUROS, IMPOSTOS, DEPRECIAÇÃO E AMORTIZAÇÃO SOBRE O ATIVO (EBITSAT) E AS VARIÁVEIS DE GOVERNANÇA EM 1998................................................125

QUADRO 37 - RESUMO DOS RESULTADOS DA PESQUISA .128 


\section{Lista de Figuras}

FIGURA 1 - O PROBLEMA DE AGÊNCIA DOS GESTORES E A GOVERNANÇA CORPORATIVA................................. 14

FIGURA 2 - TEMAS DO PROGRAMA DE GOVERNANÇA CORPORATIVA DA CALPERS ..........................................20

FIGURA 3 - FORMAS PELAS QUAIS AS EMPRESAS CONSEGUEM ATRAIR CAPITAL.............................................29

FIGURA 4 - CÍRCULO VICIOSO DA GOVERNANÇA CORPORATIVA NO BRASIL ......................................................39

FIGURA 5 - CÍRCULO VIRTUOSO PROPOSTO PARA A GOVERNANÇA CORPORATIVA NO BRASIL..........................40

FIGURA 6 - O PROCESSO DECISÓRIO DA ALTA GESTÃO SEGUNDO FAMA E JENSEN (1983)...............................49

FIGURA 7 - RELAÇÃO ENTRE A VARIÁVEL VALOR DA EMPRESA SOBRE ATIVO TOTAL (FIRMVSAT) E A VARIÁVEL TAMANHO DO CONSELHO (TOT) EM 2000 ................................................................................105

FIGURA 8 - RELAÇÃO ENTRE A VARIÁVEL VALOR DA EMPRESA SOBRE ATIVO TOTAL (FIRMVSAT) E A VARIÁVEL TAMANHO DO CONSELHO (TOT) EM 2000 SEM A UTILIZAÇÃO DA ESCALA LOGARÍTMICA 107 FIGURA 9 - RELAÇÃO ENTRE A VARIÁVEL VALOR DA EMPRESA SOBRE ATIVO TOTAL (RSAPR) E A VARIÁVEL TAMANHO DO CONSELHO (TOT) EM 2000

FIGURA 10 - RELAÇÃO ENTRE O LUCRO ANTES DOS JUROS, IMPOSTOS, DEPRECIAÇÃO E AMORTZAÇÃO SOBRE O ATIVO TOTAL (EBITSAT) E A VARIÁVEL TAMANHO DO CONSELHO (TOT) EM 1999 119

FIGURA 11 - RELAÇÃO ENTRE O LUCRO ANTES DOS JUROS, IMPOSTOS, DEPRECIAÇÃO E AMORTZAÇÃO SOBRE O ATIVO TOTAL (EBITSAT) E A VARIÁVEL TAMANHO DO CONSELHO (TOT) EM 1998 .126 


\title{
1. Problema de Pesquisa
}

\author{
"The directors of such [joint-stock] companies, however, being \\ the managers rather of other people's money than of their \\ own, it cannot well be expected that they should watch over \\ with the same anxious vigilance with which the partners \\ in a private copartnery frequently watch over their own. \\ Like the stewards of a rich man, they are apt to consider \\ attention to small matters as not for their master's honor, and \\ very easily give themselves a dispensation from having it. \\ Negligence and profusion, therefore, must always prevail, more \\ or less, in the management of the affairs of such a company." \\ - Adam Smith, The Wealth of Nations, apud Jensen e Meckling (1976)
}

\subsection{Introdução}

$\mathrm{Na}$ economia capitalista, as empresas que se utilizam do mercado de capitais possuem um papel primordial criação de tecnologia, aumento da produtividade e geração de riqueza. O desenvolvimento dos mercados de capitais, principalmente a partir do início do século XX, forneceu parte significativa do financiamento necessário para o crescimento das empresas privadas, propiciando um ambiente para o surgimento da chamada "grande corporação moderna", na qual o papel de gestor da empresa passou a ser exercido não necessariamente pelo proprietário. Esta separação de papéis ocorreu como conseqüência da pulverização do controle acionário, que não poderia ser correspondida por uma pulverização semelhante do poder dentro das empresas. O processo de desenvolvimento dos mercados de capitais e a conseqüente pulverização do controle das empresas foi mais rápido e acentuado nos países que, entre outros fatores, ofereceram maior proteção legal aos investidores por meio da existência e garantia de aplicação de um conjunto de leis e regras de mercado claras.

A separação da propriedade e controle entre acionistas e gestores por meio da oferta pública de ações, característica marcante das grandes corporações modernas, fez com que surgisse a necessidade da criação de mecanismos que alinhassem os interesses dos gestores aos dos acionistas, a fim de fazer com que os primeiros procurassem sempre agir no melhor interesse de todos os acionistas, entendido como a maximização da riqueza a partir do que foi investido. A governança corporativa insere-se nesta temática, podendo ser definida como o conjunto de mecanismos internos e externos que 
visam harmonizar a relação entre gestores e acionistas, dada a separação entre controle e propriedade. Como mecanismos internos para o alinhamento dos interesses, pode-se destacar a atuação do Conselho de Administração, a remuneração dos gestores e a posse de ações por parte dos executivos. Já como mecanismos externos, pode-se ressaltar a obrigatoriedade da divulgação de informações periódicas sobre a companhia, a presença de um mercado de aquisição hostil e a existência de um mercado de trabalho competitivo. O tema vem ganhando cada vez mais destaque no âmbito acadêmico e corporativo, principalmente a partir do final dos anos oitenta, com o aumento da participação ativa dos investidores institucionais e pequenos investidores individuais nos mercados bursáteis e sua exigência crescente pela garantia de que os gestores da empresa agirão sempre de acordo com o seu interesse.

Os agentes de mercado recomendam às empresas a adoção de algumas práticas para o aprimoramento da governança corporativa. Essas práticas são descritas em diversos "Códigos das Melhores Práticas de Governança Corporativa"1 que, em última instância, visam criar mecanismos corporativos para harmonizar as relações entre acionistas e gestores. Entre as principais práticas constantes da maioria dos códigos de governança, estão a necessidade de uma participação ativa e independente do Conselho de Administração, o fornecimento de informações precisas e transparentes para o mercado e igualdade de direitos entre todos os acionistas.

O senso comum indica que empresas com uma estrutura de governança corporativa mais adequada às práticas recomendadas pelos agentes de mercado obtenham melhores resultados e também sejam melhor avaliadas pelo mercado no preço das suas ações do que empresas com uma estrutura de governança não tão adequada, ceteris paribus. Desta forma, parece estar implícita a hipótese de que a estrutura de governança corporativa da empresa afeta seu desempenho e valor de mercado. Neste contexto, o objetivo do presente estudo é contribuir para esta discussão, por meio da busca da existência de uma relação quantitativa significativa entre variáveis de governança corporativa, desempenho e valor da empresa.

\footnotetext{
${ }^{1}$ A relação completa dos "Códigos das Melhores Práticas de Governança Corporativa" utilizados como referência no presente estudo se encontra no Anexo A
} 


\subsection{Formulação da Situação Problema}

O conjunto de mecanismos necessários para harmonizar a relação entre gestores e acionistas decorre da tentativa de resolução do problema de agência. O trabalho que inaugurou a linha de pesquisa sobre o problema de agência foi publicado por Jensen e Meckling (1976), que desenvolveram todo um corpo teórico tratando dos inevitáveis conflitos de interesses entre acionistas, gestores, credores e funcionários de uma empresa. O raciocínio se baseia nas relações entre "agentes" e "principais", nas quais os agentes representam, em tese, os interesses dos principais. É o caso, por exemplo, do acionista (o principal, neste caso) e do administrador (agente) de uma organização. O problema de agência ocorre quando o agente, que deveria agir sempre no melhor interesse do principal (razão pela qual é contratado), age tendo em vista o seu melhor interesse, isto é, tendo em vista maximizar sua utilidade pessoal. Como não há conflitos de interesse possíveis quando o mesmo indivíduo acumula as funções de acionista e administrador, o problema de agência surge na medida em que propriedade e controle se separam.

Dentro da perspectiva do problema de agência, Shleifer e Vishny (1997, p.737) definem governança corporativa como o "conjunto de mecanismos pelos quais os fornecedores de recursos garantem que obterão para si o retorno sobre seu investimento". O conceito de fornecedores de recursos engloba tanto os credores quanto os acionistas, sendo que a predisposição dos mesmos injetarem recursos nas empresas é proporcional à existência e aplicação de mecanismos de proteção contra expropriação por parte dos gestores e acionistas controladores. La Porta et al. (2000b p.17) corroboram esta afirmação, constatando que as grandes empresas dos países com fraca proteção legal aos investidores têm dificuldade de captação externa de recursos, sendo a bmaioria controlada pelo estado ou por famílias que as fundaram. Além disso, os autores constatam que na maior parte do mundo, incluindo o Brasil, o problema de agência fundamental não é o definido por Berle e Means (1932) entre investidores externos e gestores, mas sim entre os pequenos investidores externos e os acionistas controladores, que possuem controle quase total sobre os gestores.

Em ambas as situações de problema de agência, um dos principais mecanismos de governança corporativa é o Conselho de Administração. Ao conselho cabe a função 
de controlar a alta gestão, ratificando as decisões relevantes tomadas e monitorando a gerência. Sob esta ótica, é de se esperar que empresas com um Conselho de Administração mais independente e ativo tendam a ter melhores resultados e, consequentemente, maior criação de valor para os acionistas.

Adotando a definição de Shleifer e Vishny (1997) como referência para o tema governança corporativa, o presente estudo investiga se, nas companhias abertas brasileiras, algumas variáveis de governança relacionadas à estrutura do Conselho de Administração afe tam o desempenho e o valor da empresa, buscando sugerir se existe alguma forma mais eficiente de estruturar a direção superior da empresa para maximizar seu valor, ceteris paribus. Em suma, busca-se minimizar os custos de agência por meio de soluções estruturais internas do Conselho de Administração, expressas pela sua composição e tamanho, que poderiam indicar a existência de um arranjo ideal de governança das empresas.

\subsection{Objetivos}

A pesquisa pretende verificar se o valor de mercado e o desempenho da companhia aberta brasileira se relacionam significativamente com sua estrutura de governança corporativa, definida pelas características do seu Conselho de Administração. Como objetivos específicos, tem-se:

- verificar, estatisticamente, se existe uma relação significativa entre governança corporativa, desempenho e valor das empresas componentes das amostras analisadas, conforme as definições operacionais adotadas;

- verificar, estatisticamente, se, além de existir uma relação significativa entre as variáveis descritas acima, esta relação aponta para o sentido proposto como melhor estrutura de governança corporativa (seção 3.2.2), isto é, conforme as recomendações dos códigos de governança do Instituto Brasileiro de Governança Corporativa (IBGC) e da Comissão de Valores Mobiliários (CVM);

- contribuir para a discussão sobre governança corporativa apresentando pesquisas que representam o estado da arte sobre o tema, haja vista a 
crescente importância do assunto no país e a relativa ausência de estudos acadêmicos sobre go vernança corporativa no Brasil;

- apresentar os sistemas de governança de alguns países com mercados de capitais mais sofisticados, comparando-os a fim de servir como aprendizado para a experiência brasileira;

- apresentar o modelo de governança corporativa adotado atualmente pelas companhias abertas brasileiras componentes da amostra, descrevendo as principais iniciativas governamentais e institucionais que vêm ocorrendo no país para que as empresas aprimorem suas práticas de governança.

\subsection{Justificativa da Pesquisa}

A governança corporativa é uma ampla área de pesquisa envolvendo finanças, economia e direito. O movimento em torno do tema é algo recente, tanto na academia quanto no mercado corporativo, com os debates se intensificando a partir do final da década de oitenta. Zingales (1998, p.1) afirma que o próprio termo governança corporativa não existia na literatura de administração de empresas no início dos anos oitenta. A busca da relação entre características de governança corporativa e o valor da empresa, foco da maior parte dos estudos sobre o tema, parte do pressuposto de que a principal responsabilidade dos executivos é adicionar valor para o acionista. Esta idéia tornou-se cada vez mais aceita e difundida atualmente. Segundo Rappaport (1998, p.1), "avaliar a empresa como intuito de gerenciá-la com base na evolução do seu valor é preocupação atual de praticamente todos os principais executivos, fazendo com que nos próximos anos a criação de valor para o acionista provavelmente se torne o padrão global para mensuração do desempenho do negócio".

É importante ressaltar que a concepção da maximização da riqueza dos acionistas como principal responsabilidade dos executivos contraria o chamado modelo de equilíbrio dos interesses dos stakeholders ${ }^{2}$ como principal objetivo dos executivos. Jensen (2001, p.2) critica a teoria de equilíbrio dos interesses dos stakeholders, afirmando que "conceder o controle a qualquer outro grupo que não aos acionistas seria

\footnotetext{
${ }^{2}$ Os stakeholders são todos os públicos envolvidos com a companhia, como clientes, empregados, fornecedores, etc.
} 
o equivalente a permitir que este grupo jogasse poker com o dinheiro dos outros, criando ineficiências que levariam à possibilidade de fracasso da corporação. A negação implícita desta proposição é a falácia que se esconde por trás da chamada teoria dos stakeholders". Ainda segundo Jensen (2001, p.2), os proponentes da teoria de equilíbrio dos interesses dos stakeholders não explicam como os conflitos entre diferentes stakeholders deveriam ser resolvidos. Segundo o autor, "esta teoria deixa os executivos sem qualquer princípio para tomada de decisão, fazendo-os responsáveis por ninguém a não ser por suas preferências pessoais - ironicamente o oposto do que os defensores da teoria dos stakeholders desejam alcançar".

A hipótese da maioria das pesquisas sobre governança corporativa é buscar descobrir uma estrutura mais eficiente de governança, tentando diminuir a diferença entre o valor da companhia caso fosse operada de forma ótima e sua avaliação atual de mercado. $\mathrm{O}$ entendimento da estrutura de governança corporativa passa pelo entendimento da estrutura de propriedade da empresa, que afeta a composição do Conselho de Administração e as relações de agência.

Segundo Patterson (2002, p.4), a busca pela relação entre governança corporativa e valor das empresas pode ser considerada uma área de pesquisa madura no exterior, tendo em vista o crescimento exponencial do número de estudos sobre o tema nos últimos anos. A seção de fundamentação teórica apresenta importantes trabalhos sobre o tema, cuja maioria é constituída por testes empíricos que procuram obter uma relação estatística significativa entre diversas variáveis associadas ao desempenho e valor da empresa e variáveis associadas à estrutura de governança corporativa. No Brasil, tanto os trabalhos teóricos sobre o tema quanto os trabalhos empíricos com a busca quantitativa pelas possíveis relações são ainda escassos e não conclusivos, justificando os esforços voltados para uma compreensão melhor sobre o tema.

$\mathrm{Na}$ medida em que o mercado de capitais se torna mais sofisticado e pulverizado, a discussão sobre o tema ganha cada vez mais destaque no âmbito corporativo. Carlsson (2001) chega a sugerir que se o século XIX foi a era dos empreendedores e o século XX foi a era do gerenciamento, o século XXI será a era da governança corporativa, definida por ele como a forma pela qual o poder será exercido em todas as corporações do mundo. No Brasil, como demonstração da importância do 
tema, a Bolsa de Valores de São Paulo (Bovespa) lançou em 2001 uma classificação de "Níveis Diferenciados de Governança Corporativa" das empresas, classificando-as em nível 1 ou 2 de acordo com o grau de compromisso assumido pela empresa com relação a algumas práticas societárias. Também no Brasil, foi fundado, em 1995, o Instituto Brasileiro de Governança Corporativa, com o objetivo de difundir o tema no país. Atualmente, entidades governamentais como a Comissão de Valores Mobiliários (CVM), o Banco Nacional de Desenvolvimento Econômico e Social (BNDES) e a Secretaria de Previdência Complementar (SPC) consideram o aprimoramento das práticas de governança das empresas brasileiras algo fundamental para o desenvolvimento do mercado de capitais nacional.

Todo o movimento em torno da governança corporativa se justifica pela hipótese de que o assunto é importante para o desempenho e valor das empresas. Como é este o questionamento da pesquisa, justifica-se a contribuição para o tema dentro do campo de administração de empresas no Brasil. Em um sentido mais amplo, o entendimento da governança corporativa visa não somente ilustrar a discussão sobre melhorias marginais nas economias com mercados de capitais sofisticados, mas também poder estimular mudanças institucionais profundas em lugares onde elas precisam ser feitas. O entendimento e a adoção de melhores práticas de governança corporativa pelas empresas brasileiras poderia, caso confirmada a hipótese da sua importância, ser útil para ajudá-las a se tornarem mais eficientes e para desenvolver o mercado de capitais nacional.

\subsection{Delimitação}

A primeira delimitação importante do estudo ocorre no campo teórico. Nesta pesquisa é aplicada uma estrita perspectiva de agência, entendida como o potencial de expropriação da riqueza dos investidores pelos gestores em uma situação de separação do controle e propriedade, ou como o potencial de expropriação da riqueza dos acionistas minoritários pelos acionistas controladores em uma situação na qual os controladores exercem poder quase que total sobre os gestores. O objetivo da aplicação de tal perspectiva é saber como os investidores, tanto terceiros (credores) quanto acionistas (compradores de ações), podem aumentar a probabilidade de que os gestores 
devolvam-lhes o dinheiro aplicado com o devido retorno. O estudo não lida com os fundamentos da Teoria de Contratos, que podem ser encontrados em Hart e Holmstrom (1987) e Hart (1995). Também não aborda os elementos básicos da Economia dos Custos de Transação, que podem ser encontrados em Alchian e Demsetz (1972), Williamson (1985), Grossman e Hart (1986), Holmstrom e Tirole (1989) e Hart (1995). O estudo também não pretende realizar considerações sobre uma ampla variedade de padrões de propriedade não capitalistas, como cooperativas e organizações sem fins lucrativos. Hansmann (1996) discorre sobre a governança corporativa em organizações deste tipo.

Com relação à definição operacional de governança corporativa, o foco é dado nas características do Conselho de Administração, não abordando outros mecanismos internos importantes para diminuição dos custos de agência, como a remuneração dos gestores e a posse de ações pelos executivos. Além disso, o estudo não aborda mecanismos externos para diminuição do problema de agência, como a presença de um mercado de aquisição hostil, a existência de um mercado de trabalho competitivo e o ativismo dos investidores institucionais.

Outra delimitação importante da pesquisa é a amostra analisada, que é composta por todas companhias abertas não financeiras negociadas na Bolsa de Valores de São Paulo (Bovespa) e na Sociedade Operadora de Mercado de Ativos (SOMA) que apresentaram liquidez significativa nos anos de 1998, 1999, 2000. Para o presente estudo, entende-se como empresas com liquidez significativa as empresas que apresentaram índice de liquidez anual maior que $0,001 \%$ do índice da empresa com maior liquidez no respectivo ano. Após a aplicação do critério de liquidez mínima para definição da amostra da pesquisa, obteve-se 218 empresas nos anos de 1999 e 1998 e 215 empresas no ano de 2000. Portanto, no total foram coletados dados de 594 empresas. Os mesmos testes foram repetidos para cada ano, com objetivo de checar a persistência dos resultados. 


\subsection{Hipóteses da Pesquisa}

Relacionam-se, abaixo, as hipóteses propostas para o trabalho:

$\mathrm{H}_{0}$ (hipótese nula): não existe relacionamento significativo entre as variáveis selecionadas de governança corporativa e as variáveis de desempenho ou valor das empresas componentes da amostra.

$\mathrm{H}_{1}$ (hipótese alternativa 1): existe um relacionamento significativo entre as variáveis selecionadas de governança corporativa e as variáveis de desempenho ou valor de mercado das empresas componentes da amostra. Ademais, as empresas com melhor estrutura de governança corporativa, conforme descrito na seção 3.2.2, apresentam melhor desempenho e maior valor de mercado, ceteris paribus.

$\mathrm{H}_{2}$ (hipótese alternativa 2): existe um relacionamento significativo entre as variáveis selecionadas de governança corporativa e as variáveis de desempenho ou valor de mercado das empresas componentes da amostra. Entretanto, o tipo do relacionamento diverge daquele descrito na hipótese alternativa 1. 


\section{Fundamentação Teórica}

\subsection{Introdução}

A discussão sobre a governança corporativa envolve a criação de mecanismos internos e externos que assegurem que as decisões corporativas serão tomadas no melhor interesse dos investidores, de forma a maximizar a probabilidade dos fornecedores de recursos obterem para si o retorno sobre seu investimento. Desta forma, o entendimento sobre governança corporativa passa pela compreensão do motivo pelo qual é necessária a criação desses mecanismos, o que é explicado no presente estudo a partir da estrita perspectiva do problema de agência dos gestores.

Sob esta perspectiva, apesar dos executivos serem contratados para tomar decisões no sentido de maximizar a riqueza dos acionistas, eles muitas vezes acabam tomando decisões que maximizam sua utilidade pessoal, destruindo valor corporativo. $\mathrm{O}$ problema de agência dos gestores é, portanto, a base para o entendimento dos problemas de governança corporativa e, consequentemente, o ponto de partida para descobrir a melhor estrutura de governança a ser empregada.

A fundamentação teórica da pesquisa se inicia na seção 2.2 com a discussão do problema de agência dos gestores, visualizando a empresa como um nexo de contratos e discutindo temas como os direitos residuais de controle (juízo gerencial), formas de expropriação da riqueza dos investidores por parte dos executivos e utilização de contratos de incentivo e contratos de dívida como forma de diminuição dos custos de agência.

Após o entendimento do alicerce teórico para a questão da governança, são apresentados na seção 2.3 os sistemas de governança presentes no mundo, com ênfase nos países com maior disponibilidade de estudos sobre o assunto. Nesta seção, descreve-se a evolução das discussões sobre o tema nos últimos anos, além de ser apresentada uma comparação entre os sistemas de governança corporativa dos países. 
Em seguida, na seção 2.4, discute-se a governança corporativa no Brasil, descrevendo o modelo geral de governança das companhias abertas brasileiras e a evolução da discussão sobre o tema nos últimos anos, com ênfase nas iniciativas governamentais e institucionais para aprimoramento da governança das empresas brasileiras, como a Nova Lei das Sociedades Anônimas, os códigos de governança do Instituto Brasileiro de Governança Corporativa e da Comissão de Valores Mobiliários (CVM), o lançamento dos níveis diferenciados de governança corporativa da Bovespa e as resoluções adotadas pela Secretaria de Previdência Complementar (SPC) e pelo Banco Nacional de Desenvolvimento Econômico e Social (BNDES).

Após o entendimento conceitual do tema e um panorama sobre a evolução da sua discussão no mundo e no Brasil, é apresentada na seção 2.5 a abordagem legal para a governança corporativa. A hipótese central dessa abordagem é que o mecanismo chave para a análise das diferenças na estrutura de propriedade e nos sistemas de governança das empresas é a avaliação da eficácia da proteção legal que os investidores recebem. La Porta et al. apud Leal e Valadares (2002, p.4) reforçam essa hipótese, apontando a existência de uma forte correlação negativa entre a qualidade da proteção legal aos investidores e a estrutura de propriedade das empresas em 49 países. Sob esta ótica, a estrutura de governança das empresas, que é afetada pela sua estrutura de propriedade, seria uma resposta ao ambiente legal onde as companhias operam.

A seção 2.6 discute a estrutura de propriedade das empresas e seu impacto na governança corporativa, com destaque para o papel dos grandes investidores. Embora a maior parte da literatura sobre governança e sobre finanças corporativa estude o modelo anglo-saxão de estrutura de propriedade pulverizada, ressaltando o problema de agência entre gestores e acionistas, este modelo não é o que ocorre com mais freqüência no mundo, segundo La Porta et al. (1999c, p.494). Estudando grandes empresas de 27 países, esses pesquisadores constataram que o modelo de governança mais comum no mundo (e no Brasil), é o de estrutura de propriedade concentrada com participação ativa dos grandes acionistas, cujo principal problema de agência ocorre entre acionistas controladores e acionistas minoritários. Desta forma, comenta-se o papel dos grandes acionistas e credores, apresentando seus possíveis impactos positivos (maior monitoramento dos gestores) e negativos (maior potencial de expropriação dos minoritários) nas empresas. 
O papel do Conselho de Administração na governança corporativa é discutido na seção 2.7. O órgão é considerado o principal mecanismo interno para diminuição do problema de agência dos gestores, atuando como elo nas relações entre acionistas e gestores e entre acionistas controladores e minoritários. São descritas as principais responsabilidades do conselho e discutidas as maneiras pelas quais o órgão pode se estruturar para ser mais eficaz. Três características principais do conselho são discutidas: a separação de cargos de diretor executivo e presidente do conselho, sua composição e seu tamanho. São apresentados vários estudos acadêmicos com testes empíricos similares aos aplicados na presente pesquisa, visando investigar como a estrutura do Conselho de Administração afeta o valor e o desempenho corporativo. A descrição destes estudos corrobora a escolha feita na presente pesquisa de características do conselho para a definição operacional de governança corporativa. Por fim, é discutida a possível relação endógena entre estrutura do conselho e desempenho, haja vista que o conselho pode ser não apenas causa do desempenho corporativo, mas também conseqüência.

Em resumo, embora o Conselho de Administração seja o tema mais debatido nos trabalhos sobre governança corporativa e o teste aplicado no presente estudo envolva características do órgão, procura-se na fundamentação teórica mostrar como o assunto é bem mais amplo, envolvendo conceitos da teoria de agência, proteção legal aos investidores e estrutura de propriedade. Além desses temas, existem outras questões importantes ligadas à governança corporativa que, em virtude do foco escolhido para a pesquisa, não são discutidas, como a remuneração dos gestores, a posse de ações por parte dos executivos e conselheiros, o ativismo dos investidores institucionais, a presença de um mercado de aquisição hostil e a existência de um mercado de trabalho competitivo. 


\subsection{O Problema de Agência dos Gestores}

As discussão sobre a necessidade de aprimoramento da governança corporativa nas empresas surgiu como resposta aos diversos registros de expropriação da riqueza dos acionistas por parte dos gestores. Estes registros decorrem do problema de agência, que ocorre quando os executivos tomam decisões com o intuito de maximizar sua utilidade pessoal e não a riqueza dos acionistas, motivo pelo qual são contratados. Desta forma, o entendimento do problema de governança corporativa passa pela compreensão de como ocorre o problema de agência nas empresas e de quais mecanismos poderiam ser empregados para sua diminuição.

Jensen e Meckling (1976, p. 308), definem um relacionamento de agência como "um contrato onde uma ou mais pessoas - o principal - engajam outra pessoa - o agente para desempenhar alguma tarefa em seu favor, envolvendo a delegação de autoridade para tomada de decisão pelo agente". Segundo os autores, se ambas as partes agem tendo em vista a maximização das suas utilidades pessoais, existe uma boa razão para acreditar que o agente não agirá sempre no melhor interesse do principal. No caso da relação entre acionistas e gestores, os acionistas podem limitar as divergências monitorando as atividades dos executivos e estabelecendo incentivos contratuais apropriados eles. Desta forma, os acionistas incorrem em custos para alinhar os interesses dos gestores aos seus, que são chamados custos de agência. Segundo Jensen e Meckling (1976, p.308), os custos de agência são a soma dos:

1. custos de criação e estruturação de contratos entre o principal e o agente;

2. gastos de monitoramento das atividades dos gestores pelo principal;

3. gastos promovidos pelo próprio agente para mostrar ao principal que seus atos não serão prejudiciais ao mesmo;

4. perdas residuais, decorrentes da diminuição da riqueza do principal por eventuais divergências entre as decisões do agente e as decisões que iriam maximizar a riqueza do principal.

$\mathrm{Na}$ relação entre acionistas e gestores, os custos de agência do tipo "perdas residuais" se manifestam de forma muito clara com algumas decisões não maximizadoras de riqueza tomadas pelos gestores. O problema de agência dos gestores, com alguns dos seus principais custos, é apresentado na ilustração a seguir: 


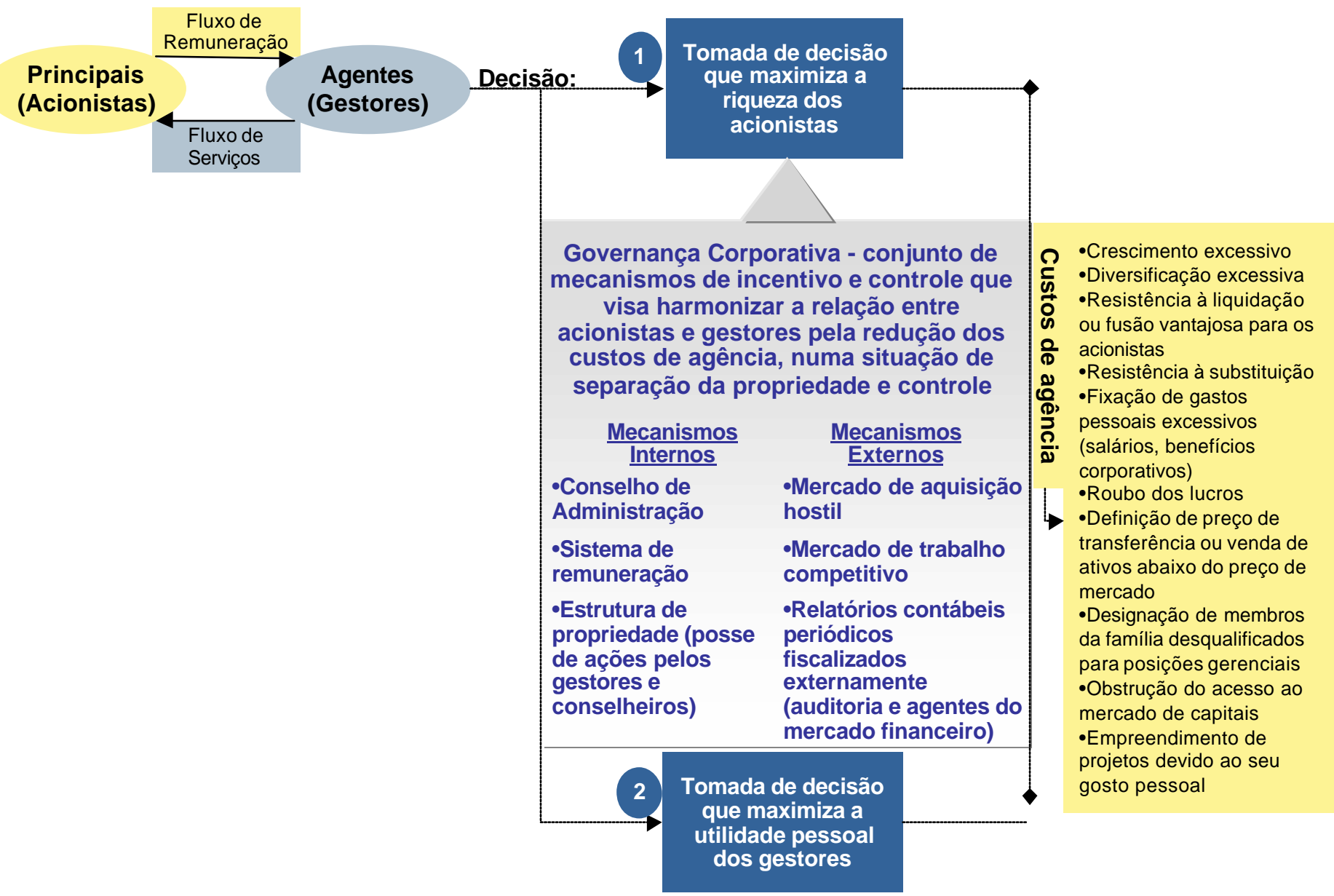

O problema de agência é um elemento essencial da chamad visão contratual da empresa, desenvolvida, entre outros, por Coase (1937), Jensen e Meckling (1976) e Fama e Jensen (1983). A essência do problema de agência é o conflito de interesses possibilitado pela separação entre a propriedade e controle, se referindo às dificuldades que os investidores tem em garantir que seus fundos não serão expropriados ou perdidos em projetos não atrativos. Segundo Jensen (2001, p.1) a visão contratual se baseia na idéia de que a firma é um nexo de contratos entre clientes, trabalhadores, executivos e fornecedores de material e capital. Sob a visão contratual, os executivos e acionistas assinam um contrato que especifica o que os gestores devem fazer com os recursos da empresa. Idealmente, os gestores deveriam assinar um contrato completo, que especificasse exatamente o que deveriam fazer a cada instante e como o excesso de caixa deveria ser alocado em cada possível contingência. O problema é que, como muitas contingências são difíceis de serem descritas e previstas, os contratos completos são tecnologicamente inviáveis. Segundo Jensen (2001, p.33), "é claro que, dada a 
ocorrência de eventos inesperados, nem todos os contratos, sejam eles explícitos ou implícitos, podem ser cumpridos". Devido a este problema na elaboração dos contratos, os investidores e gestores tem que alocar os direitos residuais de controle, isto é, os direitos de tomar decisões em circunstâncias não previstas nos contratos. Segundo Zingales (1998, p.16), não haveria necessidade do debate sobre governança caso estivéssemos em um mundo na qual todas as contingências futuras pudessem ser descritas ex ante nos contratos.

Além do conflito de agência entre gestores e acionistas, a presença de grandes acionistas gera o conflito de agência entre acionistas controladores e minoritários, causando graves problemas de governança corporativa. A compra das ações do bloco de controle das empresas com um determinado prêmio evidencia que o controle é valorizado, indicando que os controladores poderão ter acesso a benefícios especiais. Caso os acionistas minoritários recebessem os mesmos benefícios dos acionistas controladores, em tese não deveria haver o pagamento de um prêmio pelo bloco de ações que levam ao controle da empresa.

\subsubsection{Juízo Gerencial ${ }^{3}$}

Como os contratos são incompletos e os executivos possuem mais conhecimento do negócio do que os acionistas, os primeiros geralmente ficam com o direito residual de controle, isto é, com o livre arbítrio para tomada de decisão na alocação dos recursos da empresa. Esta situação dá margem para um comportamento incorreto dos executivos, tendo em vista sua utilidade pessoal. Segundo Jensen (2001, p.33 e p.57), os piores problemas de agência resultantes do juízo gerencial (livre arbítrio por parte dos gestores) ocorrem em empresas com excesso de caixa e poucas oportunidades de investimento.

Segundo Shleifer e Vishny (1997, p.746), grande parte das evidências de comportamento gerencial inadequado foram obtidas por meio de estudos de evento, na qual se mede a reação do preço das ações ao anúncio de determinadas ações dos gestores. A idéia é que a variação anormal das ações sinaliza se a atitude foi feita em

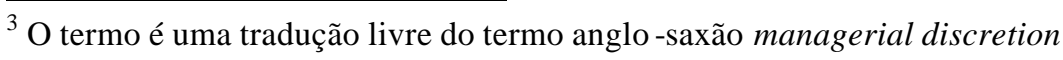


favor dos acionistas (aumento das ações) ou no interesse dos gestores (queda das ações). A principais formas pelas quais os executivos expropriam a riqueza dos investidores são:

- pela diversificação excessiva da empresa;

- pelo crescimento maior do que o necessário, com o reinvestimento do fluxo de caixa livre em projetos não agregadores de valor;

- pela determinação de remuneração abusiva para si próprios;

- pelo roubo dos lucros;

- pela venda da produção, ativos, ou títulos da empresa abaixo do preço de mercado para outra empresa das quais são controladores. Estes mecanismos de preço de transferência e desmonte de ativos são conhecidos como tunneling e, apesar de eventualmente serem legais, possuem de maneira geral o mesmo efeito que um roubo;

- pela designação de membros da família desqualificados para posições gerenciais (nepotismo);

- pelo empreendimento de projetos devido ao seu gosto pessoal e não devido à estudos técnicos de viabilidade;

- pela resistência à liquidação ou fusão vantajosa para os acionistas.

Além dessas formas de expropriação, os gestores também podem expropriar a riqueza dos acionistas pela proteção excessiva de suas posições, ficando no emprego mesmo quando não são mais competentes ou qualificados para dirigir a empresa. Os trabalho de Williamson (1985) e Grossman e Hart (1986) mostram que o oportunismo gerencial, na forma de expropriação ou má alocação dos recursos da empresa, reduz a quantidade de recursos que os investidores desejariam aplicar ex ante para financiar a empresa.

\subsubsection{Contratos de Incentivo}

Segundo Jensen e Meckling (1976, p.310), uma solução parcial para o problema do direito residual de controle dos executivos é conceder aos gestores um incentivo ex ante de longo prazo que alinhe os interesses dos executivos ao dos investidores. Fama (1980), demonstra que os contratos de incentivo podem assumir uma variedade de 
formas, incluindo distribuição de propriedade, opções para compra de ações ou ameaça de demissão se o desempenho for ruim.

Segundo Shleifer e Vishny (1997, p.745), o principal problema dos contratos de incentivo é que eles criam um enorme potencial para ganhos extras por parte dos gestores, principalmente quando eles negociam seus contratos de incentivo com conselhos de administração passivos ou por eles dominados. Como exemplos, os gestores podem definir os termos do contrato já sabendo se e quanto os lucros irão subir, ou podem manipular os números contábeis e a política de investimento para aumentar sua remuneração. Como boa parte dos contratos de incentivo entre gestores e acionistas se baseia em medidas contábeis da companhia, ressalta-se o papel fundamental da contabilidade na governança corporativa. Em resumo, devido aos problemas de estabelecimento de metas e mensuração dos resultados, não se pode afirmar que os contratos de incentivo por si só resolvem o problema de agência.

\subsubsection{Contratos de Dívida}

O estabelecimento de contratos de dívida pode ser um mecanismo na resolução dos problemas de agência. A dívida é um contrato no qual o tomador de empréstimo recebe recursos do emprestador, prometendo pagar por meio de um fluxo de caixa futuro. A característica definidora do débito é a possibilidade dos credores exercerem controle quando do não pagamento da dívida. Desta forma, caso o tomador viole algum dos termos do contrato, o emprestador pode assumir certos direitos, como ficar com algum ativo da empresa (colateral) ou levar a empresa à falência. Uma característica essencial da dívida, portanto, é que uma falha do tomador em cumprir o contrato aciona uma transferência de direitos de controle do tomador para o emprestador. Grossman e Hart (1986) e Jensen (1986) discutem o papel da dívida no comprometimento do pagamento dos fluxos de caixa livres (recursos da empresa disponíveis para reinvestimento ou distribuição de dividendos) para os investidores.

Muitos estudos modelam os custos e benefícios das dívidas. Os benefícios normalmente se dão pela redução dos custos de agência, pela diminuição do número de projetos implementados com Valor Presente Líquido (VPL) negativo, ou pela pressão 
para a venda de ativos que valem mais se aplicados em outros usos. Os principais problemas da dívida são a possibilidade das empresas deixarem de empreender bons projetos devido a compromissos contratuais de não aumentarem seu financiamento com terceiros e a obrigatoriedade imposta por credores da empresa liquidar seus ativos em situações nas quais não seria economicamente eficiente tomar essa decisão. Stulz (1990), Harris e Raviv (1991) e Hart e Moore (1995), entre outros, apresentam alguns modelos que incorporam a questão dos contratos de dívida.

\subsection{Sistemas de Governança Corporativa no Mundo}

O sistema de governança corporativa adotado pelas empresas depende, em grande parte, do ambiente institucional no qual está inserida. O Estado, através da definição dos sistemas financeiro e legal, modela a formação do mercado de capitais local e do grau de proteção dos investidores, influenciando o modelo de governança das empresas. Desta forma, os países apresentam diferenças significativas entre os sistemas de governança corporativa das suas empresas.

Segundo Shleifer e Vishny (1997, p.737), a maior parte das economias de mercado avançadas tem resolvido seu problema de governança corporativa de uma forma no mínimo razoável, garantindo enormes fluxos de recursos para as empresas e o retorno dos lucros aos fornecedores de recursos. Entretanto, conforme evidências dos problemas de governança no mercado acionário norte-americano em 2002, isto não significa que as economias desenvolvidas resolveram o problema da governança corporativa de forma ótima.

Existem diferenças acentuadas entre os melhores sistemas de governança corporativa do mundo, como o anglo-saxão, o alemão e o japonês, mas as diferenças entre eles são provavelmente menores do que as diferenças com relação aos outros países menos desenvolvidos. De acordo com Pagano, Panetta e Zingales (1998, p.40), os mecanismos de governança corporativa da Itália são tão subdesenvolvidos que retardam de forma substancial o fluxo de capitais externos para as empresas. O argumento de Barca (1995), é o de que a limitação no grau de separação entre propriedade e controle e a grande estabilidade dos controladores nas empresas 
dificultam a presença de um mercado de aquisição hostil, obstruindo as restruturações necessárias e limitando as oportunidades das pessoas. Segundo Shleifer e Vishny (1997, p.740), em países do antigo bloco socialista, os mecanismos de governança corporativa também são muito precários.

\subsubsection{A Governança Corporativa nos Estados Unidos}

A pulverização do controle acionário é uma característica das grandes empresas americanas. Segundo Roe (1994) apud Matsusaka (1996), é difícil encontrar um acionista com mais de 10 porcento das ações de uma empresa listada entre as 500 maiores do país. Como resultado, o autor afirma que os acionistas possuem pouco incentivo ou capacidade para afetar as políticas corporativas definidas pelos gestores, resultando em uma situação na qual os executivos são fortes e os proprietários são fracos.

Neste contexto, o movimento em torno da governança corporativa surgiu nos EUA, em meados da década de oitenta, como resposta a diversos casos de abuso de poder e expropriação da riqueza dos acionistas por parte dos executivos, que naquela época dominavam os Conselhos de Administração. Esta resposta foi dada em grande parte pela atuação dos investidores institucionais, principalmente fundos de pensão, cujo ativismo tornou-se sinônimo do termo governança corporativa no país. Carlsson (2001, p.25) ressalta o papel pioneiro do fundo de pensão dos funcionários públicos da Califórnia, Calpers (California Public Employees Retirement System), como grande propulsor do movimento da governança corporativa nos EUA. O fundo de pensão é um dos maiores do mundo, gerenciando, segundo Carlsson (2001, p.26), cerca de US\$ 166 bilhões de dólares no ano de 2000, com cerca de US\$ 115 bilhões investidos em ações de mais de 1500 empresas. Segundo o autor, o estopim para o movimento foi a recusa de uma oferta de compra da Texaco em 1984 pelos seus executivos, prejudicando os acionistas, em um caso típico de defesa dos empregos por parte dos gestores. Após este caso, o Calpers adotou imediatamente uma resolução afirmando que, como investidores de longo prazo, não iriam mais aceitar comportamento similar de outras empresas. O fundo elaborou uma lista de problemas a serem enfrentados, como a dependência do conselho em relação aos gestores, o aumento excessivo dos salários dos executivos e os diversos arranjos para evitar ofertas de compra hostis, denominados poison pills. 
Uma das medidas iniciais adotadas pelo Calpers foi atuar decisivamente na criação, em 1985, do Conselho dos Investidores Institucionais (CII - Council of Institutional Investors), uma associação com o objetivo de cuidar dos interesses dos investidores institucionais e que atuou como importante organismo de lobby para alterar a legislação americana, de forma a melhor resguardar os interesses dos acionistas. Em conjunto com outros investidores institucionais, o Calpers passou também a monitorar as práticas de governança corporativa das empresas, expondo na mídia as empresas que apresentavam deficiências, como conselhos passivos ou pagamento de salários excessivos aos executivos. Além disso, os investidores passaram a concentrar mais seus votos nas assembléias gerais dos acionistas, elegendo maior número de conselheiros independentes.

Segundo Carlsson (2001, p.29), o programa de governança corporativa do Calpers teve três etapas sobrepostas, que, de uma forma geral, retratam o desenvolvimento do tema governança corporativa nos Estados Unidos:

Figura 2 - Temas do Programa de Governança Corporativa da Calpers

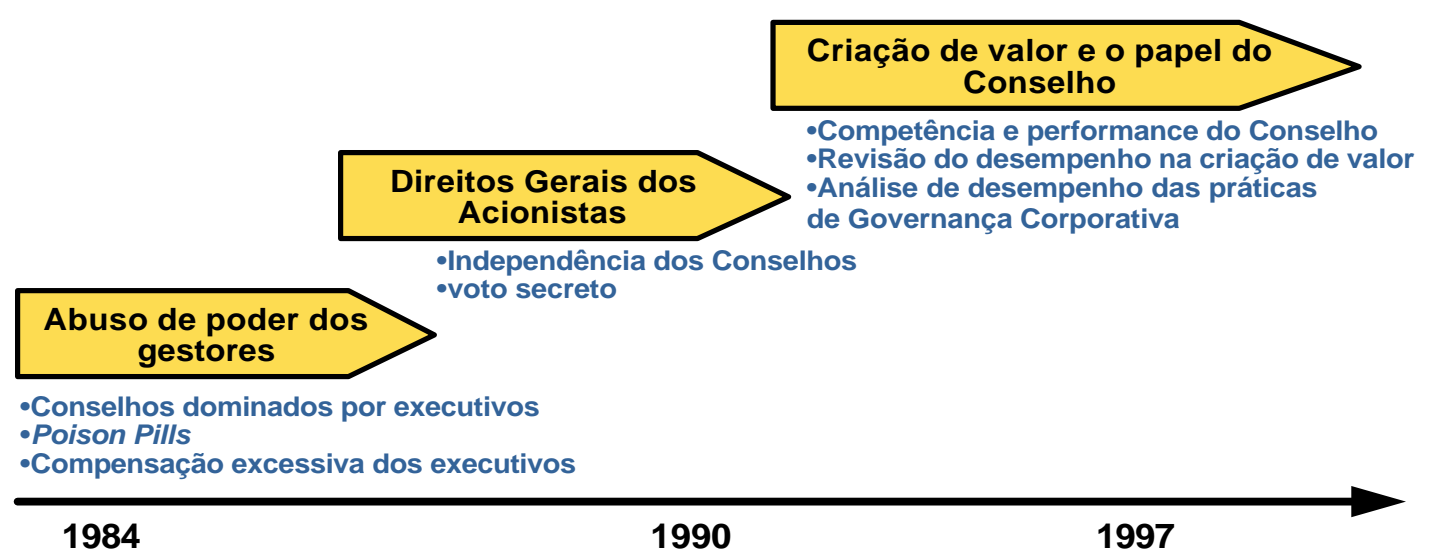

Fonte: Carlsson, R. H., "Ownership and Value Creation: Strategic Corporate Governance in the New Economy", John Wiley e Sons, EUA, 2001, pág. 29.

$\mathrm{O}$ ativismo de diversos investidores institucionais resultou em mudanças nas práticas de governança corporativa de boa parte das empresas americanas durante a década de noventa, ocasionando, por exemplo, o aumento da proporção de membros independentes nos conselhos e o aumento dos casos de demissão de diretores executivos por causa de mau desempenho. Segundo Bhagat e Black (1999, p.923), atualmente quase todas as empresas americanas possuem maioria de membros externos no conselho 
(não executivos), sendo que a maioria já possui inclusive maioria de membros independentes (conselheiros profissionais) nos conselhos. É importante ressaltar que, embora tenha tido um papel fundamental, o Calpers não mudou sozinho o panorama de governança corporativa nos EUA. Outras organizações, como o Council of Institutional Investors (CII), o Institutional Shareholder Services (ISS) e o Teachers' Insurance and Annuity Association - College Retirement Equities Fund (TIAA-CREF), maior fundo de pensão do mundo com US\$ 260 bilhões sob gestão ${ }^{4}$, também desempenharam importante papel. Essas instituições elaboraram códigos de governança corporativa que deveriam ser seguidos pelas empresas, condicionando a compra de ações ao cumprimento das diretrizes constantes dos códigos.

Como forma de mostrar aos investidores o cumprimento de algumas práticas de governança corporativa, as próprias empresas americanas começaram a elaborar suas diretrizes de governança corporativa. Uma pesquisa realizada em 1994 pelo Calpers com as 300 maiores companhias dos EUA mostrou que mais da metade estava desenvolvendo, ou já havia desenvolvido, diretrizes de governança corporativa.

\subsubsection{A Governança Corporativa no Reino Unido}

Assim como nos Estados Unidos, a pulverização do controle acionário também é uma característica da grande maioria das companhias abertas do Reino Unido, caracterizando ambos os países dentro do chamado modelo anglo-saxão de governança corporativa. Segundo Carlsson (2001, p.51), uma série de escândalos nos mercados corporativo e financeiro no final dos anos oitenta levou o governo do Partido Conservador a deixar claro que medidas legislativas iriam ser tomadas caso o próprio mercado não se estruturasse de forma a prevenir a ocorrência de novos escândalos. Como conseqüência, a bolsa de valores de Londres (London Stock Exchange), apoiada por outros organismos, formou um comitê destinado a revisar os aspectos de governança corporativa relacionados às práticas de contabilidade e aos relatórios financeiros. Este grupo de trabalho, denominado Comitê Cadbury, publicou em dezembro de 1992 um relatório que constituiu o marco inicial do movimento da

\footnotetext{
${ }^{4}$ Informação apresentada por Carlsson (2001, p.39)
} 
governança corporativa no país, intitulado The Financial Aspects of Corporate Governance.

A crescente pressão por parte dos investidores institucionais para a definição de regras sobre algumas questões importantes não abordadas no Comitê Cadbury, principalmente relacionadas à remuneração dos executivos e conselheiros, levou a formação de um grupo de trabalho denominado Comitê Greenbury em 1995, cujo relatório trouxe importantes avanços na determinação de práticas de governança ligadas à remuneração dos administradores.

Em novembro de 1995, a bolsa de valores de Londres, em conjunto com diversas entidades, formou outro grupo de trabalho destinado a elaborar altos padrões de governança corporativa. Este grupo, denominado Comitê Hampel, tinha como objetivo revisar o relatório do Comitê Cadbury e aproveitar os principais pontos do Comitê Greenbury. Além dos aspectos de responsabilidade e remuneração dos gestores e conselheiros, analisados nos comitês anteriores, o Comitê Hampel também discutiu a principal responsabilidade do Conselho de Administração, definindo-o como órgão que deve promover o aumento da prosperidade das empresas no longo prazo. Desta forma, o Comitê Hampel definiu governança corporativa dentro de uma dupla perspectiva, de responsabilidade e prosperidade do negócio. O relatório do Comitê Hampel foi publicado em janeiro de 1998 e, após o recebimento de sugestões da sociedade civil, foi alterado e lançado com título de Combined Code em julho de 1998. Este código de governança corporativa foi incorporado como uma das exigências da bolsa de valores de Londres para listagem das companhias.

\subsubsection{A Governança Corporativa na Alemanha}

Segundo Carlsson (2001, p.62), o sistema de governança corporativa alemão possui três características distintas:

- o modelo de equilíbrio dos interesses dos stakeholders (todos os públicos envolvidos com a companhia) como objetivo primordial das empresas, ao invés da maximização da riqueza dos acionistas;

- o papel limitado do mercado de capitais no fornecimento do capital de risco; 
- a gestão coletiva das empresas.

A busca pelo equilíbrio dos interesses dos stakeholders (empregados, credores, fornecedores, etc.) como objetivo das empresas é consequiência do modelo alemão de industrialização, muito regulamentado e controlado pelo estado. Atualmente, a lei exige a presença de representantes dos empregados nos conselhos da empresas alemãs (Conselho Supervisor), sendo que companhias com mais de 2000 empregados devem ter metade dos membros do Conselho Supervisor composto por representantes dos empregados. Carlsson (2001, p.63) afirma que este modelo de equilíbrio dos interesses foi reforçado por acontecimentos traumáticos ocorridos no século 20 , como as duas guerras mundiais, hiperinflação, reformas monetárias e reintegração com a Alemanha Oriental, que fizeram com que o consenso e a colaboração se tornassem importantes valores sociais.

Outra característica do sistema de governança corporativa alemão é o subdesenvolvimento do mercado de ações, quando comparado com outras economias avançadas. Segundo Carlsson (2001, p.63), a bolsa alemã (Deutsche Börse) é pequena sob todos os aspectos, com uma capitalização de mercado equivalente a metade da bolsa de Londres. Além disso, em 1998 sua capitalização em relação ao PIB alemão era de 51 porcento, contra 167 porcento da bolsa de Londres em relação ao PIB inglês. Em contrapartida a um fraco mercado de ações, o mercado de crédito é muito desenvolvido, com forte participação dos bancos nas empresas. Este desenvolvimento do mercado de crédito como substituto do mercado de ações data do século XIX, quando os grandes bancos passaram a fornecer, além do capital de curto e longo prazos, o capital de risco e a exercer as funções de proprietários ativos das empresas.

Uma terceira característica do modelo alemão é a gestão coletiva das empresas, na qual o Conselho de Gestão, responsável pela operação da companhia, indica um presidente para representar a empresa externamente e orientar o trabalho dos membros do conselho. Este presidente divide as decisões com os outros membros do conselho, não possuindo o papel de principal tomador de decisões, como no caso do diretor executivo no Brasil ou do Chief Executive Officer americano. Carlsson (2001, p.64) sugere que esta característica tem raízes históricas, advindas dos diversos problemas que a sociedade alemã enfrentou no século XX devido à líderes com poder excessivo. 
Durante os anos noventa, as forças de mercado oriundas da globalização forçaram cada vez mais as empresas alemãs a adotarem os padrões internacionais de governança corporativa. Como exemplo dessas forças de mercado, estão o acesso das empresas alemãs às bolsas de Nova Iorque (New York Stock Exchange) e de Londres (London Stock Exchange), que exigem que elas adotem certas regras de transparência e divulgação de informações. O fortalecimento do mercado de ações alemão teve grande impulso em 1997, com a criação do Novo Mercado (Neuer Market) da bolsa alemã de Frankfurt, que vem alcançando seu objetivo de canalizar capital de risco para novas empresas. Atualmente, a maioria das aberturas de capital na Alemanha acontecem no Neuer Market, que possui regras mais rígidas de proteção e transparência aos investidores. Esta iniciativa tende a fazer com que as novas empresas alemãs já se estruturem dentro de alguns padrões internacionais de governança corporativa.

\subsubsection{A Governança Corporativa no Japão}

Como decorrência da cultura coletivista da sociedade japonesa, o objetivo das empresas no Japão tem sido a busca pelo equilíbrio dos interesses dos stakeholders e a garantia de emprego vitalício para seus funcionários. Segundo Carlsson (2001, p.80), uma conseqüência da política de emprego vitalício é a priorização, por parte das empresas, de metas de crescimento absoluto e de participação no mercado ao invés da maximização dos lucros. Entretanto, a pressão internacional por maior competitividade vem fazendo com que, como forma de sobrevivência, muitas empresas japonesas tenham que abandonar a política do emprego vitalício.

Outra característica marcante do sistema corporativo japonês são os keiretsu, conglomerados de várias empresas e bancos unidos por redes de participações cruzadas entre eles. Os bancos são a principal fonte de recursos para as empresas, exercendo o papel de financiadores dos conglomerados. Como as taxas de juros no Japão são muito baixas, o reduzido custo dos recursos acaba sendo um motivo adicional para diminuição do incentivo pela priorização da lucratividade.

As empresas japonesas utilizam o conceito de um único Conselho de Administração. Segundo Carlsson (2001, p.85), o conselho típico das grandes empresas 
japonesas é composto exclusivamente por executivos da companhia, que são indicados como recompensa por serviços prestados. Desta forma, conselhos grandes, com cerca de 50 membros, são comuns nas grandes companhias japonesas. Quase sempre o homem forte do conselho é o presidente da companhia, que é responsável pela seleção dos novos conselheiros e possui mais poderes do que o presidente do conselho. Portanto, um conselho típico japonês, com número excessivo de membros e composição exclusivamente interna, tem funções meramente cerimoniais, não sendo um agente eficaz de governança corporativa.

Tendo em vista a necessidade de aprimoramento dos mecanismos de governança no país, a Federação Japonesa das Organizações Econômicas (Japanese Federation of Economic Organizations) publicou em 1997 um relatório denominado "Recomendações Urgentes com Relação à Governança Corporativa" (Urgent Recommendations Concerning Corporate Governance). Este relatório reconhece a necessidade de adaptação das empresas japonesas aos padrões internacionais de governança corporativa, como forma de manutenção da competitividade do país no século XXI. O relatório sugere às empresas japonesas a adoção de suas próprias diretrizes de governança e a busca por um melhor funcionamento do Conselho de Administração. Além disso, recomenda a ampliação da função dos auditores e melhorias na transparência das informações ao mercado.

Em 1998, foi a vez do Fórum de Governança Corporativa do Japão (Corporate Governance Forum of Japan) estabelecer um comitê de governança corporativa que elaborou um relatório denominado Princípios de Governança Corporativa - Uma Visão Japonesa (Corporate Governance Principles - A Japanese View). Este relatório, apesar de ter como base o Combined Code britânico, elaborou diretrizes mais modestas, como a necessidade de explicação formal das empresas em caso de unificação dos cargos de presidente do conselho e presidente da companhia e a recomendação para diminuição dos tamanho dos atuais conselhos de Administração, com 50 a 60 conselheiros. Segundo o relatório, o documento deve evoluir para um código de governança a ser seguido pelas empresas japonesas. Algumas empresas, como a Sony, já se anteciparam, reduzindo seu Conselho de Administração de 50 para 10 membros, se tornando um exemplo que pode ser seguido por outras corporações. 


\subsubsection{A Governança Corporativa na França}

Segundo Charkham (1994) apud Carlsson (2001, p.70), a França é um país muito peculiar na estrutura de governança das suas empresas, apresentando basicamente dois sistemas de governança corporativa, os Sistemas I e II. O Sistema I é o mais comum, sendo caracterizado por um único Conselho de Administração e pela presença de um líder da organização que combina os cargos de presidente do conselho e diretor executivo, denominado Président Directeur Générale (PDG). Neste sistema, há uma concentração de poder, pois o papel do PDG é descrito por lei e os cargos de diretor executivo e presidente do conselho não podem ser separados. O Sistema II foi uma alternativa criada pelo poder público nos anos sessenta, inspirada pelo modelo alemão. Neste sistema, utilizado apenas por um pequeno percentual das empresas, existem dois conselhos, o Conselho de Administração (Conseil de Surveillance) e o Conselho de Gestão (le Directoire).

A presença do Estado através do controle direto das empresas tem sido outra característica marcante do sistema de governança francês. Esta característica data desde o início da industrialização francesa, principalmente nos serviços de utilidade pública, como eletricidade e ferrovias. Entretanto, a forte onda de privatizações ocorrida nos anos noventa fez com que a presença do Estado nas empresas tenha se tornado cada vez menor.

De maneira geral, as características do sistema francês, de poder centralizado na figura do PDG e forte presença estatal, fazem com que a governança corporativa do país ainda não se enquadre nos padrões de transparência, responsabilidade e preocupação com todos os acionistas exigidos pela maioria dos códigos de governança. Entretanto, a tendência é que as empresas francesas rapidamente adotem melhores práticas de governança corporativa, pois, por ser um país com pequena presença de fundos de pensão domésticos e baixo investimento per capita no mercado acionário, seu mercado de capitais é muito dependente de investidores institucionais estrangeiros, que exigem um aprimoramento das práticas de governança corporativa.

Segundo Carlsson (2001, p.75), com o objetivo de aproximar a governança corporativa francesa aos padrões exigidos pelos fundos de pensão internacionais (para 
recebimento de investimentos) e pelas bolsas de valores americanas e inglesas (para listagem), foi elaborado em 1995 um relatório denominado Relatório Vienot, em homenagem ao líder da comissão e PDG do Banco Societé Generale, Marc Vienot. Este relatório foi aprimorado em 1999, com o lançamento de um segundo relatório com o mesmo nome.

Os relatórios Vienot são considerados os marcos iniciais no debate sobre governança corporativa na França. Estes relatórios abordam questões delicadas, como a proposta para separação dos cargos de presidente do conselho e presidente da diretoria, acabando com a figura do PDG. Além disso, fazem recomendações semelhantes a outros códigos das melhores práticas de governança corporativa, como a constituição de comitês no Conselho de Administração, a presença de um mínimo de conselheiros independentes e a divulgação do montante e forma de remuneração da diretoria executiva e Conselho de Administração.

\subsubsection{Comparação entre os Sistemas de Governança Corporativa}

A comparação entre os sistemas de governança corporativa dos países geralmente os diferencia a partir dos tipos de instituições que atuam como principais financiadores das empresas. Allen e Gale (2000) argumentam que esta comparação tradicional separa os sistemas de governança entre os centrados no mercado, como os dos Estados Unidos e Reino Unido, e os centrados em bancos, como os da Alemanha e Japão.

Esta forma de comparação tem sido usada para a avaliação dos regimes de governança corporativa e para a formulação de propostas políticas para sua melhoria. Nos anos oitenta, quando a economia japonesa ia bem, a governança centrada em bancos era considerada superior porque, conforme argumento de Porter (1992), os bancos não teriam uma visão tão imediatista, permitindo às empresas focarem em decisões de investimento de longo prazo. Esta idéia é corroborada por Hoshi, Kashyap e Scharfstein (1991), que afirmam que os bancos também dariam recursos para as empresas com problemas de liquidez, evitando onerosos problemas financeiros. 
Nos anos noventa, quando a economia japonesa entrou em dificuldade, o pêndulo se moveu para o outro lado. Kang e Stulz (2000, p.28) mostram que, longe de serem promotores de investimentos racionais, os bancos japoneses exigiam restrições orçamentárias muito pequenas para as empresas, emprestando demais para as que estavam em declínio e que deveriam passar por uma reestruturação total. Nesta linha, Morck e Nakamura (1999) afirmam que os bancos japoneses, ao invés de facilitar a governança, fazem conluios com gestores para deter ameaças externas ao seu controle.

Alguns estudiosos, entretanto, consideram infrutífera a comparação dos sistemas de governança entre centrados nos bancos ou no mercado, isto é, entre centrados nos mercados de crédito ou de ações, propondo classificá-los a partir dos diferentes níveis de proteção legal aos investidores. La Porta et al. (2000b p.18) são alguns destes estudiosos, afirmando que alguns países possuem ambos mercados de crédito e de ações fortes ou fracos, sendo inconsistente classificá-los meramente como centrados em bancos ou no mercado (quadro abaixo). Os autores afirmam que a diferença entre os sistemas de governança dos países é melhor explicada pelas diferenças entre os direitos dos investidores, isto é, pela eficácia da proteção legal oferecida aos fornecedores de recursos 5 .

Quadro 1 - Classificação dos sistemas de governança dos países pelas fontes de recursos

\begin{tabular}{|c|c|c|c|}
\hline País & Bancos & Mercado de Ações & Classificação \\
\hline Alemanha & Fortes & Não Desenvolvido & Centrado em Bancos \\
\hline EUA & Não Fortes & Desenvolvido & Centrado no Mercado \\
\hline Japão & Fortes & Desenvolvido & Indefinida \\
\hline França & Fracos & Não Desenvolvido & Indefinida \\
\hline Itália & Fracos & Não Desenvolvido & Indefinida \\
\hline
\end{tabular}

Fonte: La Porta, R., Shleifer, A., Lopez-De-Silanes, F. e Vishny, R.W., "Investor Protection and Corporate Governance", Journal of Financial Economics, Oct. 2000.

Tendo em vista diferentes sistemas de governança presentes no mundo, como compará-los em termos de sua eficácia na atração de recursos dos investidores para as empresas? Shleifer e Vishny (1997, p.739) descreve m como as empresas conseguem atrair capital apesar dos esperados custos de agência, sugerindo como poderia ser estruturado um sistema de governança eficaz. Segundo os autores, algumas empresas

\footnotetext{
${ }^{5}$ Esta linha de raciocínio, denominada abordagem legal para a governança corporativa, é apresentada em detalhe na seção 2.5
} 
conseguem captar recursos sem dar em troca qualquer poder aos investidores, devido apenas à sua reputação no mercado de capitais ou ao otimismo excessivo dos investidores. Esta situação, entretanto, ocorre com poucas empresas e de forma esporádica, de acordo com os ciclos no mercado financeiro. Na maioria das vezes, as empresas têm que conceder poder aos investidores em troca de recursos. Uma das formas de concessão de poder aos investidores é através de uma efetiva proteção legal contra expropriação dos gestores e acionistas controladores. Quando da ausência da proteção legal, o mecanismo alternativo é a concentração da propriedade em grandes investidores, que possuem incentivos (por terem muitos recursos alocados) e direitos de controle suficientes para diminuir o problema de agência gerencial. Desta forma, uma combinação de proteção legal aos investidores e uma certa concentração da propriedade são elementos essenciais e complementares de um bom sistema de governança corporativa e a chave para uma comparação entre os sistemas de governança. As formas pelas quais as empresas podem conseguir financiamento sugeridas por Shleifer e Vishny (1997) são resumidas na seguinte figura:

\section{Figura 3 - Formas pelas quais as empresas conseguem atrair capital}

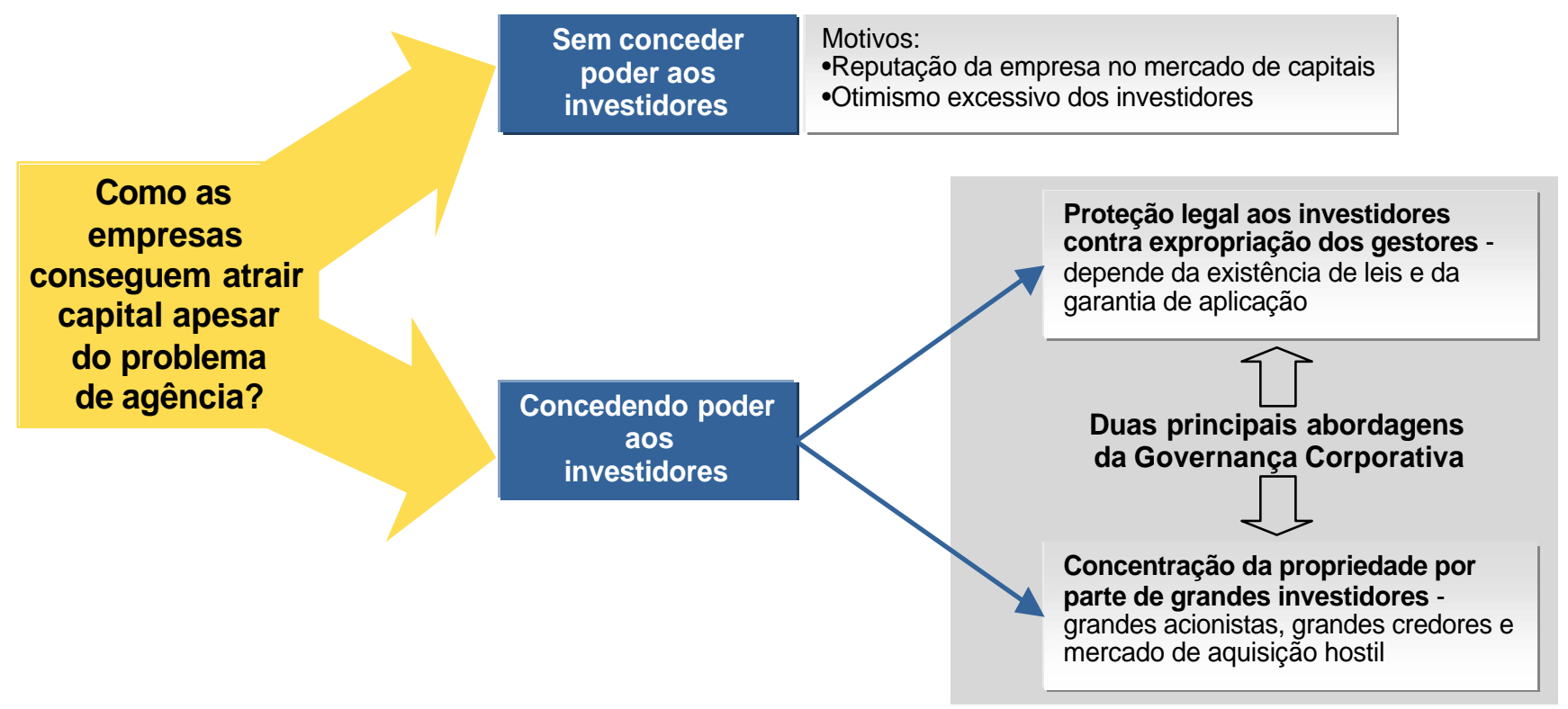

Fonte: Shleifer, A. e Vishny, R.W., “A Survey of Corporate Governance”, The Journal of Finance, Jun.1997.

Os sistemas de governança corporativa mais desenvolvidos, dos Estados Unidos, Reino Unido, Alemanha e Japão, possuem uma combinação em diferentes proporções de proteção legal aos investidores e concentração da propriedade. Segundo La Porta et al. (2000b p.23), os EUA e o Reino Unido possuem um sistema legal que garante maior proteção relativa aos acionistas do que aos credores, fomentando o mercado de capitais. 
Grandes investidores são menos freqüentes, exceto quando a propriedade é concentrada de forma temporária em processos de aquisição. Na Alemanha, os credores possuem mais direitos do que nos EUA, porém os direitos dos acionistas são mais fracos. A Alemanha, portanto, possui um sistema de governança caracterizado pelos grandes investidores (grandes acionistas e bancos), mas com baixa participação de pequenos acionistas no mercado. O Japão se situa entre os EUA e a Alemanha no grau de proteção de acionistas e credores e, como resultado, possui tanto grandes investidores de longo prazo (apesar de não tão fortes quanto na Alemanha) quanto um mercado de pequenos investidores desenvolvido. Em suma, todos esses sistemas de governança corporativa possuem méritos e, mais importante do que compará-los a fim de obter uma classificação qualitativa, deve-se ressaltar que todos possuem diferentes combinações de proteção legal aos investidores e uma certa concentração da propriedade.

Na maior parte do resto do mundo, a proteção legal aos investidores é muito menos eficaz, tanto por causa da ausência de leis apropriadas quanto pela fragilidade do sistema judiciário em fazer cumprir a lei. Como conseqüência, as empresas continuam controladas pelas famílias e, mesmo em países ricos como a Itália, têm dificuldade em levantar recursos externos, financiando a maior parte do seu investimento internamente. Pagano, Panetta e Zingales (1998, p. 28) relatam as grandes dificuldades que as empresas italianas enfrentam para captar recursos fora da Itália. Barca (1995) apud Shleifer e Vishny (1997, p. 740), sugere que também é difícil de se conseguir financiamento via bancos na Itália. A maioria dos sistemas de governança corporativa do mundo, incluindo o do Brasil, parece ser mais parecido com a Itália do que com EUA, Alemanha e Japão. Como resultado da falta de proteção legal aos investidores, o financiamento no Brasil é em sua maioria interno ou por meio de bancos estatais e existe uma grande concentração da propriedade.

Conforme exposto, as instituições econômicas e legais dos países afetam de maneira decisiva o sistema de governança corporativa adotado pelas empresas. Estas instituições podem ser alteradas através do processo político, tornando mais ou menos eficiente o sistema de governança corporativa de um determinado país. Portanto, o Estado pode atuar de forma decisiva no aprimoramento da estrutura de governança corporativa das empresas, alterando o ambiente institucional pelo aumento da proteção legal aos investidores e pelo fomento do desenvolvimento do mercado de capitais. 


\subsection{A Governança Corporativa no Brasil}

Apesar das principais formas de constituição das companhias abertas no Brasil (empresas privadas nacionais, estatais e subsidiárias de multinacionais) gerarem diferentes modelos de governança, a análise de pesquisas sobre governança corporativa no Brasil realizadas pelo IBGC (2001) e pela MCKINSEY \& COMPANY e KORN/FERRY INTERNATIONAL (2001), permite traçar um modelo geral de governança corporativa para as empresas brasileiras listadas em bolsa, com as seguintes características:

- estrutura de propriedade com forte concentração das ações com direito a voto (ordinárias) e alto índice de emissão de ações sem direito a voto (preferenciais);

- empresas com controle familiar ou compartilhado por alguns poucos investidores alinhados por meio de acordo de acionistas para resolução das questões relevantes;

- presença de acionistas minoritários pouco ativos;

- alta sobreposição entre propriedade e gestão, com os membros do conselho representando os interesses dos acionistas controladores;

- pouca clareza na divisão dos papéis entre conselho e diretoria, principalmente nas empresas familiares;

- escassez de conselheiros profissionais no Conselho de Administração;

- remuneração dos conselheiros como fator pouco relevante;

- estrutura informal do Conselho de Administração, com ausência de comitês para tratamento de questões específicas, como auditoria ou sucessão.

A forte concentração das ações com direito a voto é característica fundamental do modelo de governança das companhias abertas brasileiras, com uma ausência quase total de empresas com estruturas de propriedade pulverizadas. Segundo Monaco (2000, p.133), os acionistas controladores detêm, em média, $88 \%$ das ações com direito a voto emitidas. Já Leal e Valadares (2002, p.9) constatam que o maior acionista possui, em média, 58\% das ações ordinárias, enquanto os três maiores acionistas juntos possuem 78\% destas ações. A alta concentração da propriedade (posse de ações) e do controle (tomada de decisão) das companhias, aliada à baixa proteção legal dos acionistas, faz com que o principal conflito de agência no país se dê entre acionistas controladores e 
minoritários, e não entre acionistas e gestores, como nos países anglo-saxãos com estrutura de propriedade pulverizada.

Outra característica importante do modelo de governança das companhias abertas brasileiras é o alto índice de emissão de ações sem direito a voto (preferenciais). Segundo Leal e Valadares (2002, p.10), apenas $11 \%$ das companhias abertas não lançam mão deste artificio, que compreende, em média, $46 \%$ do capital total das companhias abertas. Como resultado, os autores argumentam que a emissão de ações preferenciais atua como o principal mecanismo de separação entre a propriedade e controle nas companhias, permitindo aos acionistas majoritários manterem o controle com uma participação menor no capital da empresa e, consequentemente, aumentando o incentivo para expropriação da riqueza dos pequenos investidores.

Desta forma, os benefícios de se ter um grande acionista controlador, principalmente como monitor mais eficaz dos gestores da companhia por ter grande parte dos seus recursos nela alocados ${ }^{6}$, são reduzidos em grande parte no Brasil pois, apesar da grande concentração das ações ordinárias, a emissão de grande percentual de ações sem direito a voto (ações preferenciais) e a utilização de esquemas piramidais (holdings que controlam holdings que controlam empresas) faz com que muitos controladores sejam, de fato, acionistas minoritários das empresas controladas, por não possuírem a maioria do capital social da empresa. Esta situação gera uma combinação de muito poder com baixa alocação de recursos próprios na empresa, diminuindo os benefícios de se ter um acionista controlador.

Como decorrência da grande concentração de poder, os membros do Conselho de Administração são em sua grande maioria indicados pelo acionista controlador. Esta situação reduz a possibilidade de uma postura ativa e independente dos conselhos, que é necessária para o cumprimento de suas atribuições legais de fixação da orientação geral dos negócios e fiscalização da gestão dos executivos em prol de todos os acionistas.

Nas empresas familiares, em geral, os conselheiros não são profissionais, sendo indicados pelo controlador por laços familiares ou pessoais, prejudicando a qualidade da

\footnotetext{
${ }^{6}$ Os benefícios de se ter um grande acionista na companhia são descritos com mais detalhes na seção 2.5.1
} 
análise das questões estratégicas da companhia. Nas companhias abertas recém privatizadas ou subsidiárias de multinacionais, o conselho em grande parte é composto por executivos estrangeiros da matriz, com pouca disponibilidade para tratamento das questões da subsidiária nacional. Nas empresas estatais, geralmente o conselho é composto por ocupantes de altos cargos públicos indicados por razões políticas, com baixa disponibilidade para tratamento das questões corporativas. A constatação de Monaco (2000, p.158), de que, em média, as estatais possuem 2,25 conselheiros a mais do que as empresas de controle privado nacional sugere um papel mais político e de representatividade a diversos segmentos nos conselhos das empresas estatais. Em todos os tipos de empresas, a maioria dos membros do conselho é composta por pessoas externas às empresas mas não profissionais, resultando em baixa quantidade de informação sobre a empresa e na presença de conflito de interesse pela defesa de algum acionista em específico. Estas características dos conselheiros prejudicam o desempenho do conselho na defesa do interesse de todos os acionistas.

A remuneração variável dos conselheiros, fator considerado importante pelos principais códigos de governa çca como motivador para um melhor desempenho do conselho, não é adotada pela grande maioria das empresas brasileiras, corroborando a hipótese de um papel mais consultivo e figurativo do que profissional por parte do órgão.

Algumas mudanças ocorridas nos anos noventa, como o aumento da competitividade decorrente da maior estabilidade econômica e abertura de mercado, além da maior dificuldade de obtenção de financiamento estatal, têm levado as empresas brasileiras a uma necessidade crescente de acesso aos mercados de capitais nacionais e internacionais. Esta necessidade de obtenção de recursos ao menor custo possível tem motivado as empresas a adotarem novas práticas de governança corporativa, pressionando o atual modelo de governança brasileiro, principalmente nos aspectos de maior consideração dos interesses dos acionistas minoritários, maior transparência das informações ao mercado e profissionalização do Conselho de Administração. 
Além dos incentivos de mercado decorrentes do aumento da competitividade, algumas iniciativas institucionais e governamentais também vêm contribuindo para a melhoria das práticas de governança pelas empresas brasileiras, entre as quais:

- a criação do Instituto Brasileiro de governança corporativa (IBGC), em 1995;

- a aprovação da lei no 10.303 de 31 de outubro de 2001, conhecida como a Nova Lei das SAs;

- a criação dos Níveis 1 e 2 de governança corporativa e do Novo Mercado pela Bolsa de Valores de São Paulo (Bovespa);

- o estabelecimento de novas regras pela Secretaria de Previdência Complementar (SPC) para definição dos limites de aplicação dos recursos dos fundos de pensão;

- a definição, pelo BNDES, da adoção de práticas de boa governança corporativa como um dos requisitos preferenciais para a concessão de financiamentos.

O Instituto Brasileiro de Governança Corporativa (IBGC) foi criado em 1995 com o objetivo de melhorar a governança corporativa no Brasil, sendo a única organização da América Latina totalmente focada na discussão do tema. Em 1995 o IBGC lançou o primeiro "Código das Melhores Práticas de Governança Corporativa" do país, abordando temas como o relacionamento entre controladores e minoritários e diretrizes para o funcionamento do Conselho de Administração.

Este código foi revisado em 2002, sendo a versão atual dividida em seis temas: propriedade, Conselho de Administração, função do Presidente, Auditoria, Conselho Fiscal e ética/conflito de interesses. O tema sobre a propriedade lida primordialmente com o combate ao desequilíbrio de poder entre os acionistas. Para amenizá-lo, o código recomenda que as empresas tenham apenas ações com direito a voto. Àquelas que já possuem grande parte do capital composto por ações preferenciais, a recomendação seria atribuir-lhes esse direito. Nas situações de transferência do controle, o IBGC sugere que a empresa estabeleça em estatuto a obrigatoriedade de que o comprador ofereça a todos os acionistas o direito de vender ações pelo mesmo preço a ser pago ao controlador, direito este conhecido como tag along. Se a intenção for fechar o capital, o código prevê que as ofertas públicas para retirada das ações do mercado sejam feitas pelo valor econômico, a partir de estudo elaborado por empresa independente. $\mathrm{O}$ código também define regras para o acordo de acionistas, com o objetivo de igualar os níveis de 
informação. Segundo o IBGC, o acordo de acionistas deve estar disponível para conhecimento de todos os acionistas.

O código do IBGC também faz diversas recomendações sobre a transparência das informações ao mercado, recomendando que a remuneração de cada um dos conselheiros e diretores deva estar expressa no relatório anual e que toda informação que possa influenciar decisões de investimento deva ser divulgada simultaneamente para todos os acionistas. O Instituto sugere ainda que as demons trações financeiras sejam apresentadas sob as normas internacionais. Com relação ao Conselho Fiscal, o IBGC trata-o como uma criação brasileira para preencher uma lacuna nas atividades do conselho, afirmando que o Conselho Fiscal não precisaria existir, caso o Conselho de Administração desempenhasse bem as suas funções. Com relação aos serviços de auditoria, o IBGC chama atenção para a possível perda de independência quando uma mesma companhia oferecer serviços simultâneos de auditoria e consultoria.

A Nova Lei das SAs, promulgada no final de 2001 e com vigência a partir de março de 2002, visa, por meio do estabelecimento de novas regras de funcionamento para as Sociedades Anônimas, promover maior proteção aos acionistas ordinaristas minoritários e preferencialistas. Entre as principais alterações, estão:

- a obrigatoriedade de oferta pública de aquisição de ações pelo valor econômico aos ordinaristas minoritários, em caso de: cancelamento do registro de companhia aberta, elevação da participação acionária à porcentagem que impeça a liquidez de mercado das ações remanescentes, ou em caso de fusão ou aquisição;

- a obrigatoriedade do adquirente do controle de companhia aberta realizar oferta pública de aquisição das ações ordinárias dos demais acionistas da companhia, em caso de alienação direta ou indireta de controle, sendo assegurado a estes acionistas minoritários preço equivalente a no mínimo $80 \%$ do valor pago pelo adquirente pelas ações representativas do bloco de controle;

- o direito dos preferencialistas elegerem um membro para o Conselho de Administração, desde que representem, no mínimo, 10\% (dez por cento) do capital social da companhia; 
- o direito dos acionistas minoritários elegerem um membro para o Conselho de Administração, desde que representem, no mínimo, 15\% (quinze por cento) do total das ações com direito a voto;

- a possibilidade de participação no Conselho de Administração de representantes dos empregados, facultada a decisão à empresa;

- A limitação da emissão de ações preferenciais a 50\% do total de ações emitidas, ao invés dos $67 \%$ anteriores, para as sociedades anônimas instituídas após a publicação da lei;

- O fortalecimento da Comissão de Valores Mobiliários (CVM), concedendo ao órgão maior independência funcional e financeira;

- a possibilidade do estatuto social prever a arbitragem como mecanismo de solução das divergências entre os acionistas e a companhia, ou entre os acionistas controladores e os acionistas minoritários, propiciando uma forma mais rápida para resolução de conflitos.

Apesar de alguns avanços, a Nova Lei das SAs teve no artigo 118 um retrocesso com relação às boas práticas de governança corporativa. Este artigo, que regulamenta o acordo de acionistas, estabelece no parágrafo oitavo que o voto do conselheiro representante do grupo ligado por acordo de acionistas não deverá ser computado quando sua decisão for contrária às premissas do acordo de acionistas, retirando a liberdade e independência do conselheiro e confundindo seu papel com o do acionista. A consolidação da figura do controlador pode ser considerado outro retrocesso na Nova Lei das SAs, com o termo aparecendo 25 vezes no projeto aprovado, mesmo número de aparições do termo nos 300 artigos da lei vigente. Em suma, a Nova Lei das SAs trouxe alguns avanços na defesa dos acionistas minoritários, mas não pode ser considerada uma legislação que causará o fomento do mercado de capitais brasileiro, principalmente após frustrar boa parte do mercado com o veto de 10 artigos e 27 parágrafos na data de sua aprovação.

A criação dos Níveis 1 e 2 de governança corporativa e do Novo Mercado pela Bolsa de Valores de São Paulo (Bovespa) visa destacar as empresas comprometidas com maior transparência e melhores práticas de governança corporativa, senda a adesão 
voluntária, via contrato entre as partes. São três níveis distintos, com um nível de exigência crescente na adoção de práticas diferenciadas de governança corporativa.

As Companhias Nível 1 se comprometem com melhorias na prestação de informações ao mercado e com a dispersão acionária. As principais práticas exigidas para inserção no Nível 1 são:

- manutenção em circulação de uma parcela mínima de ações (free float), representando $25 \%$ do capital;

- realização de ofertas públicas de colocação de ações por meio de mecanismos que favoreçam a dispersão do capital;

- melhoria nas informações prestadas trimestralmente, entre as quais a exigência de consolidação e de revisão especial;

- cumprimento de regras de transparência em operações envolvendo ativos de emissão da companhia por parte de acionistas controladores ou administradores da empresa;

- divulgação de acordos de acionistas e programas de opções de ações (stock options);

- disponibilização de um calendário anual de eventos corporativos.

As Companhias Nível 2 se comprometem, além da aceitação das obrigações contidas no Nível 1, a adotar um conjunto mais amplo de práticas de governança e de direitos adicionais para os acionistas minoritários, entre os quais:

- mandato unificado de um ano para todo o Conselho de Administração;

- disponibilização de balanço anual seguindo as normas do US GAAP ou IAS GAAP;

- extensão para todos os acionistas detentores de ações ordinárias das mesmas condições obtidas pelos controladores quando da venda do controle da companhia e de, no mínimo, 70\% deste valor para os detentores de ações preferenciais (tag along);

- direito de voto às ações preferenciais em algumas matérias, como transformação, incorporação, cisão e fusão da companhia e aprovação de contratos entre a companhia e empresas do mesmo grupo; 
- obrigatoriedade de realização de uma oferta de compra de todas as ações em circulação, pelo valor econômico, nas hipóteses de fechamento do capital ou cancelamento do registro de negociação neste Nível;

- adesão à Câmara de Arbitragem para resolução de conflitos societários.

O Novo Mercado exige que as empresas, além de se comprometerem com a adoção de todas as exigências do Nível 2, decidam emitir apenas ações ordinárias, acabando com o papel das ações preferenciais. O público alvo são as empresas interessadas em abrir o capital. Companhias abertas com ações preferenciais também podem entrar no Novo Mercado, desde que transformem todas as ações em ordinárias.

Dezenove empresas aderiram, em junho de 2001, ao Nível 1 de governança corporativa da Bovespa. Estas empresas foram agrupadas em um novo índice, denominado Índice de Governança Corporativa (IGC), que obteve um resultado melhor que o índice Ibovespa entre 25 de junho e 18 de dezembro de 2001. Neste período, enquanto o índice Ibovespa teve queda de 10,9\%, o IGC teve queda de $1,6 \%$.

Até o final de 2001, nenhuma empresa havia ingressado no Nível 2 ou no Novo Mercado da Bovespa. Existem motivos circunstanciais e estruturais para a falta de engajamento inicial das empresas no Nível 2 e no Novo Mercado da Bovespa. Pelo lado circunstancial, 2001 foi um ano caracterizado por diversas crises internas e externas, como a crise da energia elétrica, a deterioração da situação econômica na Argentina, a recessão mundial e o aumento da instabilidade internacional a partir dos ataques terroristas aos Estados Unidos. Estas crises ocasionaram uma queda generalizada das bolsas de valores, desvalorizando os papéis e inibindo a captação de recursos. Pelo lado estrutural, o risco país e a ausência de mecanismos legais de defesa dos minoritários faz com que o mercado de ações brasileiro seja caracterizado por uma distorção entre o preço das ações e o valor intrínseco das companhias, decorrente das altas taxas de desconto aplicadas. Esta sub-avaliação generalizada distancia cada vez mais empresas e mercado, desencorajando companhias fechadas a abrir o capital e companhias abertas a utilizarem com mais frequiência o mercado de ações. Forma-se então um círculo vicioso, no qual os investidores exigem grandes descontos para adquirirem ações de empresas pouco transparentes e com risco potencial de destruir valor ao longo do tempo, aplicando altas taxas de desconto a todas as empresas e causando um desestímulo nas companhias para utilização do mercado de capitais. Por fim, a falta de perspectiva na 
utilização do mercado de capitais como real alternativa para a capitalização da companhia desencoraja a busca das empresas pela adoção de melhores práticas de governança corporativa. Este círculo vicioso da governança corporativa no Brasil pode ser resumido na figura abaixo:

Figura 4 - círculo vicioso da governança corporativa no Brasil

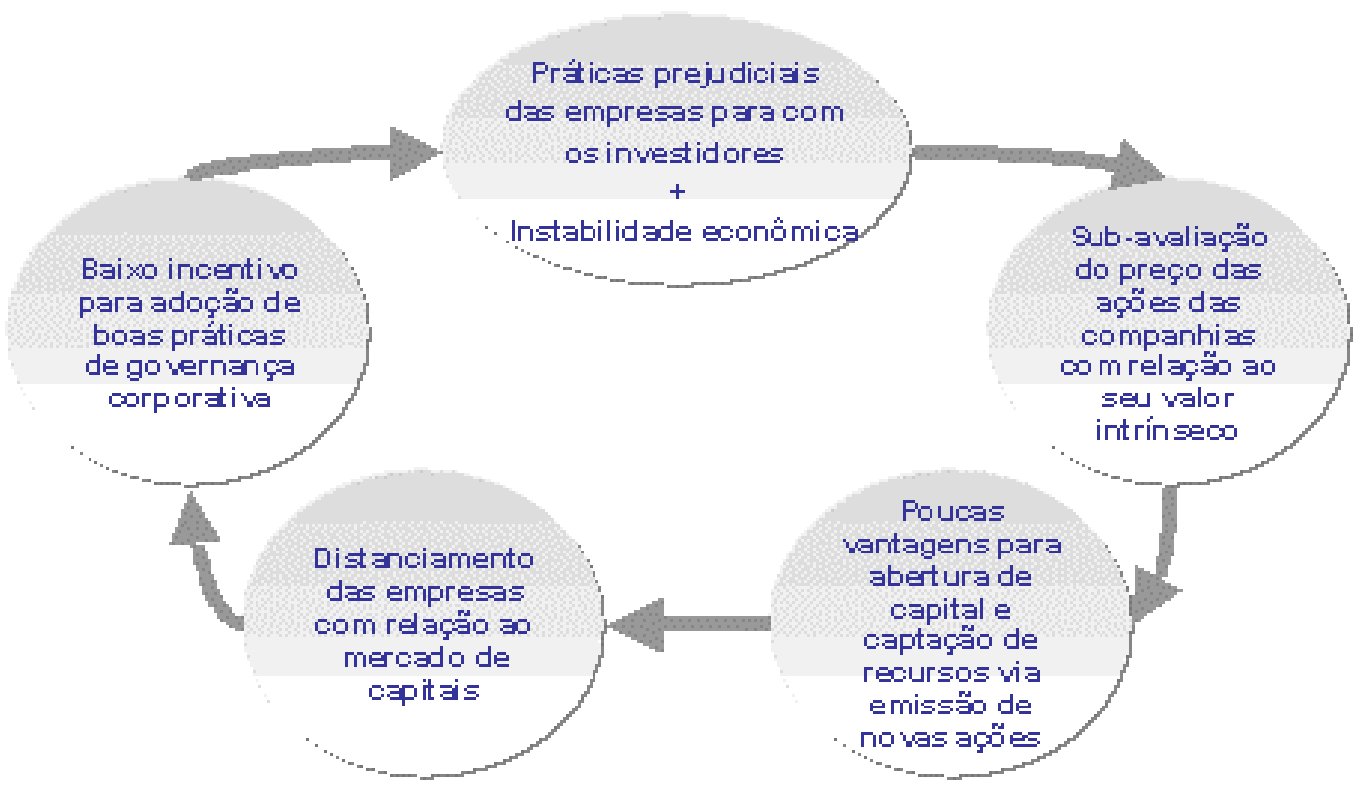

O estabelecimento de novas regras pela Secretaria de Previdência Complementar (SPC), em março de 2001, para definição dos limites de aplicação dos fundos de pensão, com base na adesão aos níveis diferenciados de governança corporativa da Bovespa, é outro importante mecanismo de estímulo para adoção de melhores práticas de governança por parte das empresas. Segundo a resolução $n^{0} 2.829 / 01$ da SPC, o percentual máximo de investimento em ações de empresas listadas no Novo Mercado da Bovespa é de $60 \%$ das reservas dos fundos com contribuição definida e de $45 \%$ para os demais planos. Já para empresas do Nível 2 da Bovespa, o limite de aplicação é de até $59 \%$ para os fundos com contribuição definida, e de até $40 \%$ para os demais. Se a empresa for listada no Nível 1, os fundos com contribuição definida poderão aplicar até $45 \%$ das reservas e os demais, até $35 \%$. Caso não esteja enquadrada em nenhum destes níveis de governança, os limites para aplicação serão apenas de 35\% dos recursos para os fundos com contribuição definida e de $25 \%$ para os demais. 
Esta medida é um estímulo adicional para a entrada das empresas nos níveis diferenciados de governança corporativa da Bovespa, haja vista o forte crescimento dos ativos dos fundos de pensão no país (cerca de $150 \%$ entre 1995 e 2001) e a necessidade de participação cada vez maior destes fundos no mercado bursátil, devido à tendência de queda das taxas reais de juros da economia no longo prazo. Segundo Savoia (2001, p.2 e p.8), em abril de 2001 havia 359 fundos de pensão no País, com patrimônio total de R\$ 140 bilhões. Deste patrimônio, 58\% estavam investidos em fundos de renda fixa, $29 \%$ em fundos de renda variável, $7 \%$ em imóveis e $6 \%$ em outras aplicações.

Em síntese, o conjunto das medidas governamentais e institucionais pode contribuir decisivamente para o fortalecimento do mercado de capitais brasileiro, criando um círculo virtuoso no qual a crescente proteção aos investidores os deixe mais seguros de que irão usufruir do retorno das companhias na mesma proporção dos controladores, aumentando sua disposição para pagar mais pelas ações e consequentemente diminuindo o custo de capital das empresas, permitindo então que as companhias utilizem cada vez mais o mercado de capitais como uma real alternativa de capitalização. Este círculo virtuoso proposto para a governança corporativa no Brasil é apresentado na figura abaixo:

Figura 5 - círculo virtuoso proposto para a governança corporativa no Brasil

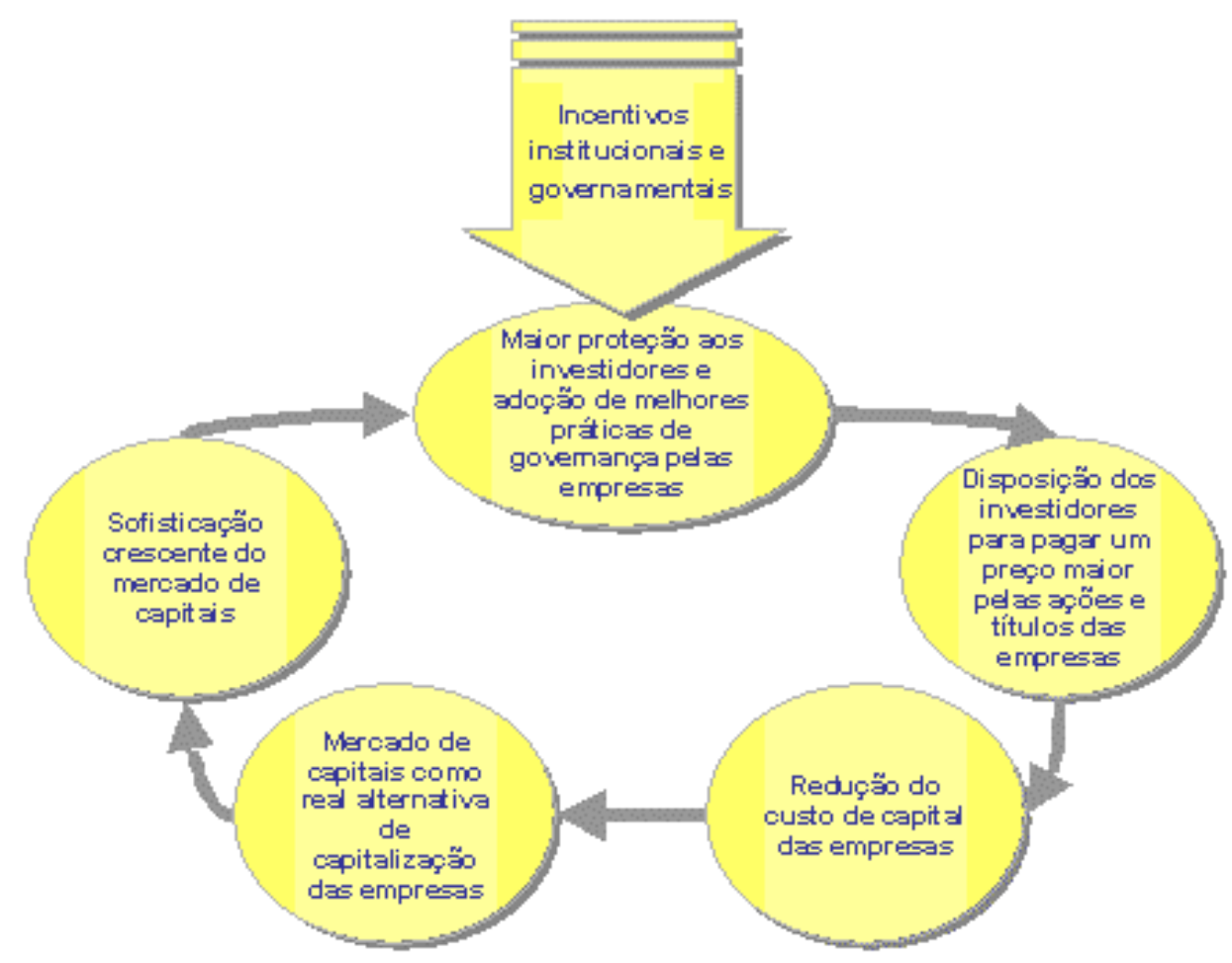




\subsection{Abordagem Legal para a Governança Corporativa}

Segundo La Porta et al. (2000b p.8), a abordagem legal para a governança corporativa é uma continuação da linha de pesquisa de avaliação de ativos que se iniciou em 1958 com as teorias de Modigliani e Miller. Segundo La Porta et al. (1998, p.1116), na visão tradicional de finanças, com base nas teorias de Modigliani e Miller (1958), os títulos são avaliados exclusivamente pelo seu fluxo de caixa. Sob este ponto de vista, um título de dívida vale o fluxo prometido de pagamento de juros e uma ação vale seu fluxo futuro de dividendos. Esta visão tradicional de finanças não explica, entretanto, como os investidores garantem que obterão para si o fluxo de recursos gerado pelos negócios das companhias e que deveriam ser usados para pagamento dos títulos de dívida ou dividendos.

Segundo La Porta et al. (2000b, p.6) uma recente linha de pesquisa, resumida em Hart (1995), define os títulos não apenas pelo fluxo de recursos que irão gerar, mas principalmente pelos direitos que eles conferem aos seus proprietários. Nesta nova corrente teórica, a idéia é modelar os instrumentos financeiros não somente de acordo com seu fluxo de caixa, mas de acordo com os direitos que eles alocam aos seus proprietários, pois os investidores irão receber dinheiro somente porque possuirão certos poderes. Como exemplo, os acionistas irão receber dividendos porque podem depor os conselheiros que não os remuneram, enquanto os credores irão receber seu pagamento porque podem exigir o recebimento de colaterais.

La Porta et al. (1998, p.1117) propõem um avanço na proposição de Hart (1995), ao afirmarem que os investidores irão receber o retorno sobre seu investimento não apenas porque possuem certos direitos, mas porque terão a garantia de que poderão exercer seus direitos. Segundo os autores, o principal fator que assegura aos investidores o retorno sobre seu investimento não é a existência de leis de proteção, mas a garantia de aplicação das leis. Desta forma, as leis e a existência de um sistema que assegure sua aplicação efetiva são elementos essenciais da governança corporativa e da própria área de finanças. Entre os direitos básicos dos credores citados pelos autores, podemos citar:

- o direito prioritário sobre o recebimento do fluxo de caixa com relação aos acionistas;

- a possibilidade de provocar falência na empresa; 
- a possibilidade de recebimento de colateral.

Já entre os direitos básicos dos acionistas, podemos citar:

- a garantia da transparência dos números da empresa por meio da aplicação de procedimentos contábeis aceitos;

- o recebimento de dividendos pró rata;

- a votação para escolha dos conselheiros;

- a possibilidade de processar conselheiros e executivos por suspeita de expropriação;

- a possibilidade de forçar o pagamento de dividendos;

- a possibilidade de liquidar a empresa e receber os recursos provenientes.

Segundo La Porta et al. (1998), o elemento decisivo para a explicação das diferenças entre os sistemas de governança corporativa nos países é o grau de proteção legal oferecido aos investidores (acionistas e credores) contra expropriação pelos gestores e acionistas controladores das empresas. Segundo esta perspectiva, chamada de abordagem legal para a governança corporativa, a estrutura de propriedade das empresas e, consequentemente, seu sistema de governança, seriam uma resposta de equilíbrio ao ambiente legal onde as empresas operam.

Como forma de corroborar a hipótese da abordagem legal, La Porta et al. (1998) examinam a existência e a garantia de aplicação de leis de proteção aos acionistas e credores em 49 países, comparando-os. Inicialmente, os autores classificam a origem das leis de cada país dentro uma das quatro tradições do direito comercial: o direito comum, o direito civil francês, o direito civil alemão e o direito civil escandinavo. $\mathrm{Na}$ sequiência, os autores criam três índices: um para medir o direito de proteção dos acionistas, outro para medir o direito de proteção dos credores e um terceiro para medir a garantia de aplicação das leis. Os resultados obtidos pelos pesquisadores são apresentados abaixo: 
Quadro 2 - Avaliação da proteção legal aos investidores de acordo com a origem das leis

\begin{tabular}{|c|l|l|l|}
\hline Colocação & $\begin{array}{c}\text { Proteção dos Acionistas } \\
\text { (pontuação) }\end{array}$ & $\begin{array}{c}\text { Proteção dos Credores } \\
\text { (pontuação) }\end{array}$ & $\begin{array}{c}\text { Garantia de Aplicação } \\
\text { das Leis (pontuação) }\end{array}$ \\
\hline $1^{0}$ & Direito Comum & Direito Comum & Direito Civil Escandinavo \\
\hline $2^{0}$ & Direito Civil Escandinavo & Direito Civil Alemão & Direito Civil Alemão \\
\hline $3^{0}$ & Direito Civil Alemão & Direito Civil Escandinavo & Direito Comum \\
\hline $4^{\circ}$ & Direito Civil Francês & Direito Civil Francês & Direito Civil Francês \\
\hline
\end{tabular}

Fonte: La Porta, R., Shleifer, A., Lopez-De-Silanes, F., Vishny, R., , "Law and Finance", Journal of Political Economy, 1998.

Em todas as análises, os países que adotam o direito civil francês (entre os quais o Brasil) apresentaram pior proteção aos investidores, mesmo controlando para o efeito da renda per capita. Por outro lado, os países que adotam o direito comum (anglosaxãos) apresentaram melhor proteção aos investidores. A hipótese de que a alta concentração da propriedade ocorre como resposta à falta de proteção legal é corroborada pelos autores, que constatam uma forte correlação negativa entre concentração da propriedade e qualidade da proteção legal aos investidores. Desta forma, os países com pior proteção legal (que adotam o direito civil francês) apresentam a maior concentração da propriedade, medida pelo percentual de ações dos três maiores acionistas. Já os países com melhor proteção legal (que adotam o direito comum) apresentam a estrutura de propriedade mais pulverizada.

La Porta et. al (1998, p.1140), também comparam a qualidade dos padrões contábeis dos países. Segundo os autores, a contabilidade possui um papel crucial na governança corporativa, já que são necessários padrões contábeis de qualidade para os investidores saberem o que se passa na companhia que estão investindo. Os resultados da avaliação dos padrões contábeis dos países foram similares aos obtidos na avaliação da garantia de aplicação das leis, com os países com direito civil francês obtendo o pior resultado.

Em sua pesquisa, La Porta et al. (1998, p.1148) fazem outras duas constatações importantes. Em primeiro lugar, diferentemente da existência de regras legais, que parece independer do nível de renda dos países, é a garantia de cumprimento das leis que diferencia a renda nos países, já que os países ricos tiveram desempenho superior em todas as medidas utilizadas para avaliar a garantia de aplicação das leis. Ademais, além de influenciar os padrões de propriedade e controle das empresas, a proteção legal 
aos investidores influencia o desenvolvimento dos mercados financeiros. La Porta et al. (1999b, p.27) e La Porta et al. (2000b, p.14) mostram que, quando comparados com países que oferecem baixa proteção legal, os países com maior proteção legal aos investidores possuem:

- maior capitalização de mercado das empresas;

- maior quantidade de companhias abertas;

- maior taxa de ofertas públicas iniciais de ações;

- maiores múltiplos P/S (preço/vendas) e P/BV (preço/valor contábil);

- maiores dividendos;

- maiores mercados de crédito.

Segundo a abordagem legal, a proteção do investidor encorajaria o desenvolvimento dos mercados de capitais porque os investidores tendem a pagar mais pelos título quando são protegidos da expropriação, tornando mais atrativa a sua emissão por parte dos empreendedores. Desta forma, o direito dos credores encorajaria o desenvolvimento do mercado de crédito e o direito dos acionistas encorajaria o desenvolvimento do mercado de ações.

\subsection{O Papel dos Grandes Investidores}

A estrutura de propriedade é um dos principais determinantes da governança corporativa. Se a proteção legal não garante direitos suficientes aos pequenos investidores de forma a induzi-los a aplicar seu dinheiro, parece haver a necessidade da presença de maiores investidores para que os acionistas tenham controle efetivo da corporação. A hipótese é que a existência de grandes investidores na companhia provoca um maior alinhamento entre os direitos sobre o fluxo de caixa (posse de ações) e os direitos de controle (votos para tomada de decisão).

Bebchuk (1999, p.2) ressalta que estruturas de propriedade pulverizadas são insustentáveis quando os investidores podem concentrar o controle sem pagar totalmente por ele, o que geralmente ocorre em países com fraca proteção legal. Bebchuk (1999, p.30) e La Porta, Lopez-De-Silanes e Shleifer (1999b, p.5) afirmam que caso dispersem o controle entre muitos investidores, os controladores acabam abrindo 
mão dos "benefícios privados do controle", que consiste na utilização dos direitos de controle para perseguir objetivos que os beneficiam ao invés de beneficiarem todos os acionistas, gerando aos controladores um ganho extra além do que seria justo pela sua fatia da propriedade. Como exemplo, Bebchuk (1999, p.2) afirma que, nos países com fraca proteção legal, uma eventual oferta pública inicial de ações propondo uma estrutura de propriedade pulverizada não seria uma situação de equilíbrio, já que provavelmente alguém iria concentrar a propriedade posteriormente tendo em vista o aproveitamento para si dos benefícios privados do controle. Bebchuk (1999, p.39) afirma que, em países onde os benefícios privados do controle são grandes, as companhias abertas tendem a ter um acionista controlador. Segundo o autor, um sistema legal que limite de forma efetiva os benefícios privados do controle poderia produzir estruturas de propriedade mais eficientes.

Segundo La Porta et al. (1999c, p.482), como a concentração da propriedade parece ser um mecanismo importante para assegurar o retorno dos investimentos nos países com menor proteção legal, os empreendedores lançam mão de diversos artifícios para aumentar o capital próprio da empresa mantendo o controle sobre ela, entre os quais:

- a venda de ações com direito de voto limitado e a posse de ações com direito de voto superior;

- a utilização de estruturas piramidais, na qual uma holding controlada pelo empreendedor vende ações de subsidiárias controladas;

- a manutenção de um grupo de empresas com uma estrutura de propriedade cruzada entre elas, tornando difícil para externos a obtenção do controle de uma empresa sem a compra de todas as outras.

Segundo La Porta et al. (1999c, p. 475), esses mecanismos para manutenção do controle são importantes para os acionistas controladores nos países com fraca proteção legal, já que uma eventual perda involuntária do controle (por meio de uma aquisição hostil ou de conluio de outros acionistas) poderia fazer com que os acionistas controladores se tornassem minoritários, perdendo os benefícios privados do controle.

La Porta et al. (2000b, p.19) enumeram vários estudos recentes que estabelecem uma ligação entre proteção ao investidor, concentração da propriedade e valor da 
empresa. Gorton e Schmid (2000) mostram que a maior concentração da propriedade por grandes acionistas é associada com maior valor dos ativos das empresas na Alemanha. Claessens, Djankov, Fan e Lang (1999, p.28) ressaltam que no Leste Asiático a maior concentração da propriedade por parte dos executivos é associada com maior valor dos ativos da corporação, ao passo que o maior controle dos votos pelos executivos é associada com menor valor dos ativos da corporação. Além disso, La Porta, Lopez-De-Silanes, Shleifer e Vishny (1999b) mostram que uma maior concentração da propriedade por parte dos executivos é associada, fracamente, com maior valor corporativo, sendo o efeito maior nos países com menor proteção aos acionistas.

De forma geral, os estudos mostram que empresas em países com fraca proteção legal precisam de controle concentrado. Bennedsen e Wolfenzon (2000, p.116) apresentam um argumento diferente. Segundo eles, quando a proteção ao investidor é fraca, é melhor para a empresa dissipar o controle entre vários grandes investidores, nenhum dos quais com poder suficiente para controlar as decisões da empresa sem a aceitação dos outros, ao invés de se ter apenas um grande investidor. Desta forma, segundo os autores, a dispersão da propriedade em grandes blocos reduziria a expropriação, resultando em uma política ótima para a maximização do valor.

Nos países com maior proteção aos acionistas, como os Estados Unidos, grandes blocos de controle são relativamente incomuns. Segundo Roe (1994), isto ocorre provavelmente devido às restrições legais sobre os bancos, fundos mútuos, companhias de seguros e outras instituições para evitar uma alta concentração da propriedade. Mesmo nos Estados Unidos, entretanto, a propriedade não é completamente dispersa, sendo a concentração de ações por famílias e indivíduos ricos mais comuns do que se acredita, conforme descrito por La Porta et al. (1999c), Demsetz (1983) e Shleifer e Vishny (1986). Além dos EUA, o Reino Unido é outro local caracterizado pela pulverização do controle acionário.

No restante do mundo, entretanto, a alta concentração de ações e a predominância do acionista controlador parecem ser a regra, corroborando a hipótese de que a concentração da propriedade em grandes investidores protege os investidores dos 
executivos em ambientes com fraca proteção legal. Basicamente, os grandes investidores podem ser constituídos por grandes acionistas ou grandes credores.

\subsubsection{Grandes Acionistas}

A forma mais direta de alinhar os direitos de controle dos acionistas com o recebimento do fluxo de caixa é concentrar a posse das ações. Uma concentração em poucos acionistas faz com que os mesmos tenham maior incentivo para coletar informações e monitorar a gerência. Grandes acionistas podem contornar o problema de agência, pois possuem tanto o interesse na maximização do valor quanto o poder suficiente para ter seus interesses respeitados. Shleifer e Vishny (1986, p.465) desenvolvem um modelo no qual a presença de grandes acionistas fornece uma solução parcial aos problemas de monitoramento dos gestores, possibilitando um aumento do valor da empresa por meio da mudança da política corporativa.

A concentração das ações em grandes acionistas, entretanto, também acarreta custos para a empresas. O custo mais óbvio, descrito por Demsetz e Lehn (1985) apud Shleifer e Visnhy (1997, p.758), é que os grandes acionistas não são diversificados, carregando, portanto, um risco excessivo. Sob este ponto de vista, como o acionista possui grande parte das sua carteira investida na empresa, ele tende a minimizar esse risco através de diversificação excessiva da empresa ou excesso de conservadorismo nos projetos empreendidos. Segundo Shleifer e Vishny (1997, p.758), outro problema importante é que os grandes investidores representam seus próprios interesses, que não necessariamente coincidem com os interesses dos outros investidores da empresa ou com os interesses dos gestores ou empregados. De forma geral, os custos potenciais de se ter grandes acionistas são a expropriação direta sobre os outros investidores, gerentes e empregados, e a expropriação pela ineficiência resultante da busca de objetivos pessoais não maximizadores de valor.

Füerst e Kang (2000, p.2), realizam um teste interessante no intuito de avaliar se a presença de grandes acionistas promove tanto uma maior criação de riqueza, indicada por um melhor desempenho, quanto a distribuição desta riqueza, indicada pelo preço das ações. A idéia do teste era medir até que ponto o maior incentivo dos grandes 
acionistas para coleta de informações e monitoramento da gerência, que pode gerar melhor desempenho, superava o efeito adverso dos grandes acionistas, que é o de colocar seus interesses acima dos outros investidores e tomar decisões sub-ótimas, que poderiam gerar impacto negativo no mercado e conseqüente redução do preço das ações. O resultado do teste de Füerst e Kang (2000, p.22) é que os grandes acionistas possuem um impacto positivo no desempenho da empresa, mas possuem um efeito adverso nos preços das ações. O resultado corrobora a idéia de que uma concentração excessiva de propriedade leva à expropriação da riqueza dos pequenos acionistas.

Grandes acionistas podem, ainda, tentar receber tratamento preferencial às custas de outros investidores e empregados. A probabilidade de recebimento deste tratamento é especialmente alta caso possuam direitos de controle significativamente maiores do que seus direitos de fluxo de caixa, isto é, poder de tomada de decisão superior ao poder de voto. Isto pode acontecer, por exemplo, caso possuam ações com direitos de votos diferenciados ou caso controlem a empresa através de uma estrutura piramidal.

Quando o alvo da expropriação por grandes acionistas são outros acionistas (minoritários), o resultado é o declínio do financiamento externo. Isto ocorre nos países que não protegem de forma satisfatória os direitos dos acionistas minoritários. Em resumo, ao mesmo tempo em que uma estrutura de governança corporativa com presença de grandes acionistas pode controlar de forma mais efetiva os gerentes, ela pode deixar os potenciais pequenos investidores desprotegidos e portanto não dispostos a investir.

\subsubsection{Grandes Credores}

Grandes credores, como bancos, também são investidores potencialmente ativos. Assim como os grandes acionistas, os grandes credores possuem substanciais investimentos na empresa e querem ver o retorno sobre seu investimento se materializar. Seu poder vem basicamente de duas formas: através de uma variedade de direitos de controle que eles recebem quando a empresa viola seus compromissos de pagamento e através dos créditos de curto prazo, que fazem com que os tomadores de empréstimos tenham que voltar de forma regular, em curtos intervalos de tempo para 
obtenção de mais recursos. Como os grandes credores possuem tanto o interesse em obter o dinheiro de volta quanto o poder para demandar este retorno, eles colocam uma pressão maior sobre os gestores, que pode gerar um melhor desempenho.

\subsection{Conselho de Administração e seu Papel na Governança Corporativa}

O Conselho de Administração tem um papel fundamental na governança corporativa das empresas, sendo o principal mecanismo interno para diminuição dos custos de agência entre acionistas e gestores, e entre acionistas controladores e minoritários. Vários agentes de mercado chegam a associar o termo governança corporativa como sinônimo de papel ativo e independente do Conselho de Administração, embora, conforme observado nas seções anteriores, o tema governança corporativa possua uma amplitude bem maior e o conselho seja somente um dos elementos componentes do sistema de governança das empresas.

Segundo Fama e Jensen (1983, p.303), o processo decisório da alta gestão envolve quatro etapas, duas das quais devem ser de exclusiva responsabilidade do conselho: a ratificação das decisões relevantes e o monitoramento da alta gestão. A estrutura do processo decisório proposta pelo autores é apresentada na seqüência.

Figura 6 - O processo decisório da alta gestão segundo Fama e Jensen (1983)

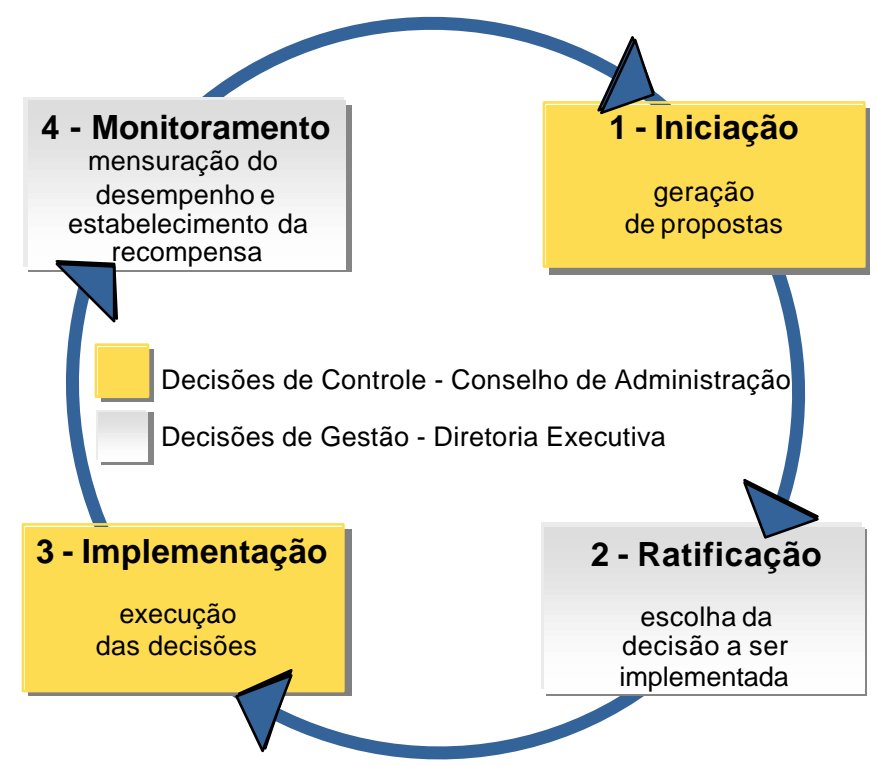

Fonte: Fama, E., Jensen, M., "Separation of ownership and control", Journal of Law and Economics, June, 1983. 
Fama e Jensen (1983, p.303) argumentam que, como as etapas de iniciação e implementação são alocadas aos mesmos agentes (executivos), ambas etapas podem ser combinadas sob a denominação decisões de gestão. Da mesma forma, as etapas de ratificação e monitoramento podem ser combinadas sob a denominação decisões de controle. Como nas companhias com separação da propriedade e controle os responsáveis pelas decisões de gestão não arcam com os efeitos totais da perda de riqueza resultante de suas decisões, é necessário que as decisões de controle sejam alocadas a outros agentes (Conselho de Administração), e que estes a executem de forma eficaz para garantir a sobrevivência da corporação. Os autores ressaltam, entretanto, que a separação das decisões de gestão das decisões de controle não precisa ser total, pois o termo significa apenas que, para uma determinada decisão, um agente não pode exercer exclusivamente os direitos de gestão e controle.

Segundo Hermalin e Weisbach (2001, p.2), a literatura sobre Conselho de Administração tem se desenvolvido no sentido inverso ao de outras áreas de estudo em finanças, pois, enquanto os artigos com base em testes empíricos são razoavelmente abundantes, os artigos teóricos sobre o tema são ainda escassos, acarretando em uma ausência de teoria formal sobre o tema. Segundo os autores, é provável que desenvolvimentos subsequentes dos estudos teóricos levem a testes empíricos mais sofisticados e com base em modelos mais robustos. Os autores afirmam que o vácuo na teoria sobre Conselho de Administração tem sido preenchido, em parte, por estudos empíricos que visam responder ao menos uma das três seguintes questões:

- como as características do conselho, como tamanho ou composição, se relacionam com o desempenho corporativo?

- como as características do conselho afetam as ações empreendidas pelo Conselho de Administração?

- quais fatores afetam a constituição do conselho e como estes fatores evoluem ao longo do tempo?

Em suma, os estudos visam associar variáveis da estrutura do Conselho de Administração, como seu tamanho, composição e distinção dos cargos de diretor executivo e presidente do conselho, com desempenho corporativo e valor da empresa. Este é o foco do presente trabalho, e nas próximas seções seguem os resultados de vários importantes estudos sobre o tema. 


\subsubsection{Composição do Conselho e Desempenho da Empresa}

Praticamente todos os códigos de governança ressaltam a importância de um Conselho de Administração composto por uma maioria de membros externos (não executivos) na companhia, como forma de melhorar a tomada de decisão e aumentar o valor da empresa. Esta recomendação reflete o senso comum de que a principal função do conselho é monitorar a gestão da empresa e que somente conselheiros externos profissionais podem ser monitores eficazes. Segundo os códigos de governança, um Conselho de Administração dominado por executivos pode atuar como um mecanismo de defesa dos gestores.

O senso comum é fortalecido por Fama e Jensen (1983, p.321), que argumentam que a inclusão de conselheiros externos profissionais aumenta a efetividade do conselho e reduz a probabilidade de conluio dos altos executivos com objetivo de expropriar a riqueza dos acionistas. Segundo os autores, os conselheiros externos teriam o incentivo de construírem suas reputações como monitores eficazes. Os próprios autores ressaltam, porém, que uma reputação como conselheiro que não cria problemas para os diretores executivos também poderia ser potencialmente valiosa para os conselheiros. Jensen (1992, p.52) reforça o argumento de que os conselheiros internos (executivos da companhia) tem menor probabilidade de monitorar o desempenho do diretor executivo, haja vista que a evolução de suas carreiras depende em boa parte do próprio diretor executivo. Segundo Jensen (2001, p.52), "como a possibilidade de uma atitude de animosidade e retribuição do diretor executivo é muito grande, é quase impossível para aqueles que se reportam diretamente ao diretor executivo participarem de forma aberta e crítica na avaliação e monitoramento do diretor executivo. Portanto, o único membro interno (executivo) do Conselho de Administração deve ser o diretor executivo".

Existem diversas pesquisas que procuram relacionar a composição do Conselho de Administração com o desempenho da empresa. Nestas pesquisas, a pergunta geral a ser respondida é "será que um conselho composto por uma maioria de membros externos (não executivos) aumenta o desempenho da empresa?". Um método utilizado tem sido examinar a correlação entre medidas contábeis de desempenho e a proporção de conselheiros externos no conselho. Bayesinger e Butler (1985) e Bhagat e Black (2000) realizam testes com esta metodologia, não obtendo em qualquer destes estudos, 
relação significativa entre medidas contábeis de desempenho e proporção de membros externos no conselho. Outro método empregado utiliza o Q de Tobin com medida de desempenho, pois, conforme Morck, Shleifer e Vishny (1988), pode-se supor que tal indicador reflete o valor agregado de fatores intangíveis, como a governança corporativa. Hermalin e Weisbach (1991) e Bhagat e Black (2000) utilizam esta abordagem, não encontrando, entretanto, relação estatística significativa entre composição do conselho e Q de Tobin.

Bhagat e Black (1999) encontram relação significativa entre composição do conselho e desempenho corporativo, constatando que os conselhos de empresas americanas com maioria de membros independentes se comportam de forma diferente dos conselhos sem esta maioria, sendo que algumas das diferenças parecem contribuir para o aumento o valor da empresa, enquanto outras parecem contribuir para a diminuição. Entretanto, ao contrário do senso comum proposto pelos diversos códigos de governança, Bhagat e Black (1999, p.948) afirmam que não existe uma evidência convincente de que uma maior independência do conselho, representada por uma maioria de conselheiros não executivos da companhia, seja correlacionada com maior lucratividade da empresa ou crescimento mais rápido.

Em seu estudo, Bhagat e Black (1999, p.950) classificam os conselheiros em três tipos: internos, afiliados externos e independentes. Os conselheiros internos são todas as pessoas que trabalham para a empresa. Os conselheiros afiliados externos são os antigos executivos, parentes de executivos e pessoas que não são funcionários da companhia, mas que provavelmente possuem relações de negócio com a empresa. Já os conselheiros independentes são os conselheiros externos sem qualquer relação com a empresa. Eles também classificam conselhos com no mínimo $50 \%$ de independentes como conselhos com maioria independente e conselhos com apenas 1 ou 2 membros internos como conselhos com super-maioria independente.

Segundo os autores, não existe apoio empírico para a proposição corrente de que as empresas devam ter uma "super-maioria de independentes no conselho", com apenas um ou dois executivos internos, conforme pregado pelos códigos de governança. Pelo contrário, os autores afirmam que existem evidências de que empresas com supermaioria independente no conselho são menos lucrativas do que outras empresas, já que 
apresentaram pior desempenho quando comparadas com outras empresas do estudo. Bhagat e Black (1999, p.953) afirmam que as empresas com maioria independente podem até ter um desempenho melhor em algumas tarefas pontuais, como substituição do diretor executivo, mas possuem um desempenho pior e outras tarefas, levando a uma vantagem líquida não significativa no desempenho geral. Como conclusão, o estudo sugere que é interessante incluir um número moderado de interno (executivos) no Conselho de Administração.

Yermack (1996) corrobora os resultados do estudo de Bhagat e Black (1999), relatando uma correlação negativa significativa entre a proporção de conselheiros independentes e o Q de Tobin, através de uma regressão múltipla. O autor não encontra, entretanto, correlação significativa entre composição do conselho e várias outras medidas de desempenho. Utilizando o mesmo tipo de teste, Agrawal e Knoeber (1996, p.395) relatam uma correlação negativa significativa ent re a proporção de conselheiros externos e o Q de Tobin.

Nenhum estudo responde de forma conclusiva se uma maioria de membros independentes constitui uma estrutura melhor para os Conselhos de Administração. Entretanto, alguns estudos fornecem pistas de uma relação curvilínea negativa entre desempenho e proporção de independentes, sugerindo que alguns conselhos podem conter membros independentes em excesso. Um destes estudos é o de Wagner, Stimpert e Fubara (1998) que, utilizando uma técnica de meta-análise ${ }^{7}$, fornecem evidências de uma relação curvilínea com coeficiente negativo entre a composição do conselho e o retorno sobre os ativos (ROA). Desta forma, seu estudo sugere que conselhos com uma proporção equilibrada entre executivos e não executivos obtêm resultados melhores. Os autores ressaltam, entretanto, que esta correlação desaparece quando o retorno sobre patrimônio líquido (ROE) é usado como medida de desempenho. Utilizando uma técnica de equações simultâneas, Barnhart e Rosenstein (1998) também encontram uma relação curvilínea, com um coeficiente negativo significativo, entre o Q de Tobin e a proporção de membros independentes no conselho, afirmando que as empresas com conselhos altamente independentes possuem valor menor, corroborando as conclusões de Bhagat e Black (1999).

\footnotetext{
${ }^{7}$ A meta-análise é uma técnica estatística que permite ao pesquisador combinar os resultados de vários estudos para estimar a relação entre duas variáveis
} 
Em outro estudo, desta vez com uma amostra maior e período mais longo de análise, Bhagat e Black (2000) testam a hipótese da correlação entre independência do Conselho de Administração e desempenho de longo prazo das grandes empresas americanas, avaliando 934 empresas durante o período de 1985 a 1995. Os autores encontram evidências de que as empresas com baixa lucratividade aumentam a proporção de conselheiros independentes, mas não encontram evidências de que esta estratégia funciona, isto é, que conselhos mais independentes aumentam a lucratividade das empresas.

Alguns estudos simplesmente não encontram qualquer relação significativa entre composição do Conselho de Administração e medidas de desempenho corporativo. Este é o caso dos estudos de Macavoy, Cantor, Dana e Peck (1983), Baysinger e Butler (1985) e Hermalin e Weisbach (1991).

As abordagens que tentam associar de forma direta a composição do conselho aos índices financeiros e valor de mercado das companhias possuem como principal aspecto positivo a facilidade de coleta e análise dos dados, pois se baseiam nas demonstrações financeiras, que são públicas e rastreáveis, assim como no preço das ações. Entretanto, estas abordagens possuem como principal aspecto negativo a dificuldade em informar como a composição do conselho realmente influencia o desempenho geral da empresa. Outra dificuldade se relaciona com a questão da endogeneidade na composição do conselho. Sob esta ótica, discutida com mais detalhe na seção 2.6.4, a composição do conselho seria, além de causa, conseqüência do desempenho corporativo. Esta é a conclusão de Hermalin e Weisbach (1998, p.97), que afirmam que a probabilidade de conselheiros independentes serem adicionados ao conselho aumenta após um desempenho ruim da companhia. Desta forma, os autores afirmam que a correlação entre composição do conselho e desempenho corporativo nas empresas tende a fazer com que as empresas com maior proporção de membros externos no conselho pareçam piores, haja vista a correlação entre proporção de conselheiros externos e fraco desempenho histórico.

Os resultados da relação entre composição do conselho, desempenho corporativo e valor da empresa são difusos, com a maioria dos estudos encontrando pouca correlação. Entretanto, é interessante notar que alguns estudos recentes relatam a 
evidência de uma relação negativa significativa entre uma alta proporção de membros independentes no conselho e o desempenho da empresa, exatamente oposto o da sabedoria convencional. Em suma, as evidências atuais sugerem uma possível correlação negativa entre conselhos com grande maioria de membros independentes e desempenho da empresa, mas não permitem afirmar com confiança que, além da correlação negativa, exista uma relação causal que comprova que conselhos com predominância de membros independentes levem a um pior desempenho das empresas.

\subsubsection{Tamanho do Conselho e Desempenho da Empresa}

Alguns estudiosos acreditam que a efetividade do Conselho de Administração diminui na medida em que ele ultrapassa um certo número de membros. Jensen (1993, p.867) argumenta que um conselho "superpovoado" possui menor probabilidade de funcionar de forma efetiva e maior probabilidade de ser controlado pelo diretor executivo. Seu argumento é consistente com a teoria de comportamento organizacional, que indica um declínio da produtividade na medida em que os grupos de trabalho vão aumentando. Segundo Jensen (2001, p.52), "os conselhos com mais de sete ou oito membros possuem uma probabilidade menor de funcionar de forma eficaz, se tornando mais fáceis de serem controlados pelo diretor executivo".

Utilizando o Q de Tobin como estimativa do valor da empresa, Yermack (1996) encontra uma relação inversa entre o tamanho do conselho e o valor da empresa, isto é, conselhos maiores relacionados com menor valor das companhias. Segundo o autor, "o resultado é robusto para muitos controles, como tamanho da empresa, setor de atuação, posse de ações por parte dos executivos, oportunidades de crescimento e estruturas de governança alternativas. Empresas com menores conselhos também apresentam melhores índices financeiros e maiores incentivos ao bom desempenho do diretor executivo, por meio de compensação e ameaça de demissão". Eisenberg, Sundgren e Wells (1998), de forma similar, encontram uma correlação negativa entre o tamanho do conselho e indicadores de rentabilidade para 900 pequenas e médias empresas finlandesas. Füerst e Kang (2000) encontram evidências de que o aumento do tamanho do Conselho de Administração possui um impacto negativo no desempenho da empresa. $\mathrm{Na}$ mesma linha de pesquisa, Brown e Maloney (1998, p. 25) afirmam que, em 
situações de aquisição hostil, conselhos menores predizem maiores retornos do preço das ações para as empresas compradoras.

Entretanto, Dalton e Daily (2000), utilizando uma técnica de meta-análise, chegam a um resultado oposto ao dos autores anteriores, concluindo que maiores conselhos são associados com melhor desempenho financeiro, independentemente de como este desempenho é medido e levando em conta a natureza da empresa. Os autores chegam a afirmar que "o tamanho do conselho é o que melhor explica a diferença no desempenho financeiro das empresas". O estudo mostra que, independentemente da proporção de conselheiros externos (não executivos), maiores conselhos são associados com melhor desempenho financeiro. Segundo os autores, as vantagens de um conselho maior são:

- aconselhamento de maior qualidade para o diretor executivo;

- possibilidade de melhor composição dos comitês do conselho, por meio da maior diversidade de experiências, atitudes e formações acadêmicas;

- possibilidade de maior informação sobre o mercado local, oriunda dos vários altos executivos no conselho com atividades em paralelo;

- maior difusão da inovação de uma empresa para outra, através da alavancagem dos contatos dos membros do conselho;

- maior probabilidade de formação de coalizões para desafiar o diretor executivo.

\subsubsection{Características do Conselho e a Execução de suas Tarefas}

Além dos estudos que buscam relacionar as características do Conselho de Administração (como composição, tamanho ou remuneração) com o desempenho corporativo, uma série de pesquisas procura examinar como as características do conselho se relacionam com a eficiência do órgão na execução das suas tarefas específicas, que segundo Bhagat e Black (1999, p.925) são:

- $\quad$ substituição do diretor executivo;

- resposta a oferta de aquisição hostil;

- aquisição de outra empresa;

- definição da compensação dos altos executivos;

- investigação sobre possíveis fraudes financeiras e de informação para o público; 
- análise sobre possível diversificação excessiva;

- definição estratégica da pesquisa e desenvolvimento da empresa;

- constituição de comitês do conselho para assuntos específicos.

Esses estudos possuem uma limitação inerente, pois dizem relativamente pouco sobre como a composição do conselho afeta o desempenho da empresa como um todo. Por exemplo, conselhos com maioria de membros independentes podem ser melhores para monitorar a gerência, como no caso da demissão de diretores executivo s, conforme Weisbach (1988), ou na tomada de decisão sobre ofertas de aquisição hostil, mas podem ser piores no aconselhamento ao diretor executivo, devido ao menor conhecimento dos conselheiros não executivos sobre a empresa e sua indústria de atuação qua ndo comparados com os conselheiros executivos.

Segundo Hermalin e Weisbach (2001, p.16), apesar dos estudos sobre a relação entre as características do conselho e a execução de suas tarefas serem limitados por não explicarem como o conselho afeta todo o desempenho da empresa, eles possuem duas grandes vantagens. Em primeiro lugar, possuem menor probabilidade de serem afetados pelo efeito da endogeneidade na formação do conselho, pois é mais clara a relação de causa e efeito entre a composição do conselho e sua tomada de decisão. Além disso, como muitos fatores influenciam o desempenho corporativo, esta abordagem possui menor propensão de ser contaminada estatisticamente por fatores não observáveis, quando comparada com a abordagem da relação direta entre características do conselho e desempenho corporativo. A eficácia do conselho no desempenho de suas tarefas específicas pode depender das suas características, principalmente da sua composição, conforme exposto nas próximas seções.

\subsubsection{Substituição do Diretor Executivo}

A tarefa primordial do Conselho de Administração, segundo diversos autores, é substituir o diretor executivo quando necessário. Sob esta ótica, ao invés de se ater à decisões operacionais sobre o negócio, o conselho deve desempenhar um papel exclusivo na seleção, monitoramento e eventual substituição do diretor executivo da 
companhia. Desta forma, Hermalin e Weisbach (2001, p.16) argumentam que uma maneira de avaliar a efetividade do conselho é analisar a qualidade dessas decisões.

O senso comum indica que conselhos com maioria de membros externos (não executivos) são mais propensos a substituir o diretor executivo do que conselhos com maioria de membros internos (executivos), haja vista a relação de subordinação dos executivos para com o diretor executivo. Weisbach (1988), realizou um estudo sobre como a decisão de demitir o diretor executivo está correlacionada com a composição do conselho. Seus resultados indicam que quando o conselho é dominado por membros externos, a substituição do diretor executivo é mais sensível ao desempenho da empresa do que quando os conselhos são dominados por executivos da companhia. Segundo o autor, os conselhos com no mínimo $60 \%$ de membros não executivos são mais propensos a demitir diretores executivos com baixo desempenho. Entretanto, o significado econômico para a empresa das demissões adicionais pelos conselhos com no mínimo $60 \%$ de não executivos é pequeno. Este resultado é consistente com a hipótese de que os conselhos dominados por externos analisam fundamentalmente o desempenho corporativo quando tomam decisões de retenção dos gestores das companhias. Em contrapartida, seus resultados corroboram a hipótese de que os conselhos dominados por executivos tomam decisões de substituição dos gestores com base em outros fatores não relacionados com o desempenho corporativo.

Apesar dos resultados de Weisbach (1988), as evidências sobre como conselhos com diferentes composições substituem o diretor executivo são difusas. Weisbach (1998) não acha uma diferença geral com base no grau de independência do conselho. Já Geddes e Vinod (1997) contrariam a sabedoria convencional, encontrando uma relação curvilínea, com um coeficiente quadrático positivo, entre a estabilidade do diretor executivo e a proporção de independentes, sugerindo que conselhos com alto percentual de membros independentes possuem menor probabilidade de substituir o diretor executivo.

Em linhas gerais, os estudos fornecem algumas evidências de que, quando da decisão de substituição do diretor executivo, conselheiros externos (não executivos) se comportam de maneira diferente do que conselheiros executivos. Entretanto, as diferenças parecem ser apenas marginais, não ficando claro a partir de que percentual os 
conselhos com maioria de membros independentes tomariam melhores ou piores decisões de substituição dos diretores executivos.

\subsubsection{Resposta à Oferta de Aquisição Hostil}

Uma outra tarefa chave do conselho é decidir se e a que preço uma companhia deve ser vendida. A defesa da companhia que é alvo de oferta de aquisição hostil pode ser usada tanto de maneira positiva para os acionistas, extraindo um preço maior do ofertante, quanto de maneira negativa, não aceitando ofertas de compra que seriam vantajosas para os acionistas. Segundo Cotter, Shivdasani e Zenner (1997, p.196), a resposta de uma empresa à oferta de aquisição hostil é um evento que cria um conflito de interesse entre acionistas e gestores, cujo comportamento dos conselheiros externos assume importância crucial para os acionis tas. O senso comum indica que conselhos com maioria de membros executivos seriam mais propensos a criar mecanismos, muitas vezes destruidores de valor, que tornassem mais difícil a venda da empresa, a fim de manter sua fonte de remuneração e posição social.

Cotter, Shivdasani e Zenner (1997, p.197) afirmam que quando uma empresa com maioria de membros independentes no conselho é alvo de oferta de aquisição hostil, ela recebe cerca de $20 \%$ a mais de retorno no preço das suas ações do que empresas similares sem maioria de membros independentes, sugerindo, portanto, que os conselheiros independentes negociam melhor a venda da companhia em favor dos acionistas do que os conselheiros internos. De forma geral, os resultados do estudo de Cotter et al. (1997, p.197) indicam que quando o conselho é independente, a resistência à aquisição hostil possui uma probabilidade maior de ser usada para aumentar o retorno para os acionistas, ao invés de ser usada para proteger os gestores da empresa alvo de aquisição hostil.

Kini, Kracaw e Mian (1995) relatam que, após a aquisição hostil de uma companhia com conselho dominado por executivos, a proporção de conselheiros independentes aumenta. Os pesquisadores também encontram a relação inversa, isto é, que empresas com maioria de membros independentes no conselho, quando adquiridas de forma hostil, diminuem a proporção de independentes. Em suma, o estudo sugere que 
a composição do conselho tende a regressar à média após uma aquisição hostil, devido a reavaliação da composição do conselho por parte do comprador.

Segundo Hermalin e Weisbach (2001, p.20), os estudos sobre o papel do conselho em empresas que são alvo de aquisição hostil fornecem evidências de que conselhos com maioria de membros independentes conseguem obter maiores preços dos ofertantes. Entretanto, não é possível concluir que conselhos com maioria de independentes produzem melhores resultados aos acionistas das empresas que são alvo de aquisição hostil.

\subsubsection{Aquisição de outra Empresa}

Segundo Bhagat e Black (1999, p.931),outro papel importante do conselho é aprovar ou rechaçar grandes decisões de investimento. Este papel é difícil de investigar, haja vista que muitas decisões não são anunciadas publicamente. Entretanto, a decisão de adquirir outra empresa é mais fácil de ser analisada, já que a comunicação ao público é exigida por lei, caso a empresa alvo seja aberta ou a aquisição seja importante para a empresa compradora. Conforme descrito anteriormente, a teoria de agência prevê que um dos seus custos mais evidentes seria a tendência dos executivos aumentarem excessivamente o tamanho da empresa, por meio de aquisições ou diversificação excessiva, a fim de aumentarem sua remuneração ou posição social. Neste contexto, poder-se-ia supor que anúncios de aquisição por parte das companhias com conselhos dominados por executivos tenham maior probabilidade de gerarem expropriação da riqueza dos acionistas, com maior probabilidade de serem mal recebidos pelo mercado. Alguns estudos sugerem essa relação negativa entre a proporção de executivos no conselho e o retorno do preço das ações no anúncio de aquisição, corroborando a hipótese de que os conselheiros independentes possuem um papel restritivo na tendência do diretor executivo construir um império corporativo a um custo excessivo.

Byrd e Hickman (1992) analisam o papel dos conselhos das empresas que realizam ofertas de aquisição de outras companhias, medindo a reação no preço das ações das empresas compradoras no anúncio da aquisição. Eles encontram uma queda anormal de $1,33 \%$ no preço das ações de todas as empresas que anunciam a aquisição de 
outras empresas. Dividindo a amostra em empresas que possuem mais que $50 \%$ de conselheiros independentes das que possuem menos de $50 \%$, os autores observam que a sub-amostra de empresas com mais de 50\% de conselheiros independentes apresenta uma pequena queda de $0,07 \%$ no preço das suas ações, enquanto que a outra subamostra, composta pelas empresas com menos de 50\% de conselheiros independentes, apresenta uma queda significativamente maior no preço de suas ações, de 1,86\%. Desta forma, o estudo conclui que empresas com conselhos de maioria de membros independentes obtêm retornos menos piores no preço das ações do que outras empresas na realização de ofertas de aquisição, provavelmente porque o mercado percebe que as empresas com conselhos mais independentes fazem aquisições menos danosas aos acionistas.

Brown e Maloney (1998, p. 31) contrapõem esta idéia, não encontrando diferença significativa na composição do conselho entre empresas que fizeram boas aquisições (medida pela variação positiva no preço das ações) das empresas que fizeram más aquisições (medida pela variação negativa no preço das ações). Subrahmanyam, Rangan e Rosenstein (1997, p.36) encontram até mesmo uma tendênc ia oposta no caso da aquisição de bancos, afirmando que uma alta proporção de conselheiros não executivos prediz um retorno menor das ações para o banco comprador.

\subsubsection{Remuneração dos altos executivos}

O estabelecimento da política de remuneração para o diretor executivo e os altos executivos da companhia é outra tarefa fundamental do Conselho de Administração. Uma visão, existente desde o trabalho de Berle e Means (1932), é que o diretor executivo pode controlar o conselho de maneira que consiga obter para si níveis "excessivos" de remuneração. Uma receita bastante adotada para evitar este problema é constituir um comitê de remuneração composto somente por membros independentes do conselho.

Core, Holthausen e Larcker (1999) estudam as relações entre composição do conselho, estrutura de propriedade e remuneração do diretor executivo, sugerindo que empresas com estruturas mais fracas de governança corporativa tendem a pagar mais 
para os diretores executivos. De forma específica, seu estudo mostra que a remuneração do diretor executivo aumenta quando aumenta: o número de conselheiros, o número de conselheiros com mais de 69 anos, o número de conselheiros externos indicados pelo diretor executivo e o número de conselheiros "ocupados", que seriam os conselheiros pertencentes a vários conselhos simultaneâmente. Yermack (1996), encontra uma relação mais forte entre desempenho corporativo e remuneração do diretor executivo nas empresas com conselhos menores, sugerindo que conselhos menores incentivam mais os diretores executivos a buscarem atingir metas de desempenho corporativo como forma de aumentar sua remuneração pessoal. Em resumo, não existe uma conclusão nos trabalhos acadêmicos se os conselheiros independentes são melhores que os conselheiros internos na determinação da remuneração dos gestores.

\subsubsection{A Relação Endógena ${ }^{8}$ Entre Estrutura do Conselho e Desempenho}

Um importante fator complicador dos trabalhos empíricos sobre Conselho de Administração, assim como de outros trabalhos empíricos sobre governança corporativa, é a dificuldade de se avaliar a endogeneidade presente nas empresas. Sob este ponto de vista, o desempenho corporativo é tanto conseqüência de atos anteriores dos conselheiros quanto causa que influencia a escolha dos próximos conselheiros. Hermalin e Weisbach (2001, p.2) afirmam que os estudos sobre conselho freqüentemente negligenciam essa questão, obtendo resultados difíceis de interpretar. Segundo Hermalin e Weisbach (1998, p.99), o problema da simultaneidade causado pelo fato da própria independência do conselho depender do desempenho corporativo torna difícil medir o efeito da independência do conselho nos resultados da empresa. Além disso, ressaltam que não existe um arcabouço conceitual para imaginar que uma composição específica do conselho seja ótima para todas as empresas.

Hermalin e Weisbach (2001, p.6) afirmam que os Conselhos de Administração são mecanismos criados de forma endógena para limitar os problemas de agência inerentes ao governo de cada organização. Segundo os autores, a qualidade das ações empreendidas pelo conselho depende, em grande parte, do seu grau de independência

\footnotetext{
${ }^{8}$ Para o presente estudo, entende-se o termo "endógeno" como algo que se origina no interior do sistema ou por fatores internos
} 
em relação ao diretor executivo. Seguindo seu raciocínio, este grau de independência depende do poder de barganha entre o conselho e o diretor executivo, que é dinâmico ao longo do tempo. Desta forma, quando o poder de barganha está do lado do diretor executivo - por exemplo, quando seu desempenho é tão bom que ele se mostra uma pessoa difícil de ser substituído à altura - a independência do conselho diminui, ao passo que quando a empresa apresenta fraco desempenho o poder de barganha do diretor executivo diminui e o conselho aumenta sua independência. $\mathrm{O}$ modelo criado por Hermalin e Weisbach (1998, p.97-98) prevê, entre outras coisas, que:

1 - um diretor executivo com fraco desempenho possui maior probabilidade de ser substituído do que um diretor executivo com bom desempenho;

2 - a substituição de pessoas no cargo de diretor executivo é mais sensível ao desempenho corporativo quando o conselho é mais independente;

3 - a probabilidade de membros independentes serem indicados para o conselho aumenta após um desempenho ruim da empresa;

4 - a independência do conselho diminui na medida que o diretor executivo aumenta sua permanência no cargo;

5 - as medidas contábeis de desempenho são variáveis que prevêem melhor a rotatividade dos gestores do que a variação no preço das ações;

6 - deve haver uma persistência de longo na governança corporativa. Em particular, mudanças que fortalecem ou enfraquecem a independência do conselho devem ser "permanentes" por alterarem o poder de barganha de longo prazo do conselho com relação aos gestores;

7 - a reação do preço das ações à mudanças no comando das empresas deve ser negativa se a demissão do diretor executivo for baseada em informações privadas, mas positiva se for baseada em informações públicas;

8 - o salário do diretor executivo não deve ter relação com o desempenho passado quando este desempenho tiver sido relativamente baixo, mas deve ser sensível ao desempenho passado quando este tiver sido acima da média.

Segundo os autores, existem fortes evidências empíricas apoiando as cinco primeiras afirmações, conforme os resultados por Weisbach (1988) e Hermalin e Weisbach (1988), entre outros estudos. Os autores também afirmam que a sexta, sétima e oitava afirmações ainda não foram testadas empiricamente. 
A abordagem endógena para análise dos conselhos de administração sugere que as empresas, a partir das suas diferentes necessidades, criam diferentes estruturas para seus conselhos, com a tendência de desenvolver estruturas que são ótimas para suas circunstâncias. Como exemplo, empresas mais maduras e geradoras de caixa teriam uma necessidade maior de terem conselhos com maioria de membros independentes, de forma a resolver problemas como o fluxo de caixa livre que não pode ser investido de maneira lucrativa no negócio da empresa.

Com base na hipótese endógena de que a composição do conselho afeta o desempenho futuro das empresas, Baysinger e Butler (1985) relatam que a proporção de membros independentes no conselho em 1970 se correlaciona com o retorno sobre o patrimônio líquido (ROE) em 1980. Este estudo apresenta a séria limitação da utilização de apenas uma medida de desempenho, além do período de defasagem muito longo. Bhagat e Black (1998) examinam se a mudança do grau de independência do conselho entre 1988 e 1991 foi correlacionado com a lucratividade ou taxa de crescimento entre 1988 e 1991 ou 1985 a 1987. De forma geral, existe pouca evidência, entretanto, de que a composição do conselho é sensível à lucratividade passada ou futura da empresa. 


\section{Metodologia da Pesquisa}

\subsection{Método Utilizado, Tratamento Estatístico e Análise dos Dados}

A pesquisa desenvolvida é quantitativa e com base em procedimentos estatísticos, objetivando produzir inferências para a população objeto a partir das amostras consideradas. Com relação ao enfoque epistemológico, a pesquisa é do tipo empírico-analítica. Segundo Martins (1994, p.26), "esta abordagem apresenta em comum a utilização de técnicas de coleta, tratamento e análise de dados marcadamente quantitativas. Têm forte preocupação com a relação causal entre as variáveis e a validação da prova científica é buscada através de testes dos instrumentos, graus de significância e sistematização das definições operacionais". Especificamente, a pesquisa utiliza uma regressão múltipla do tipo seção transversal entre as variáveis dependentes de valor da empresa e desempenho e as variáveis independentes de governança corporativa.

São utilizadas três variáveis independentes de governança corporativa, conforme a definição operacional da seção 3.2. Estas variáveis independentes são apresentadas no quadro a seguir:

Quadro 3 - variáveis independentes do estudo: governança corporativa

\begin{tabular}{|l|c|}
\hline Descrição & Legenda \\
\hline Diretor executivo como presidente do conselho & DE \\
\hline Tamanho do Conselho de Administração & TOT \\
\hline Independência do Conselho de Administração & INDEP \\
\hline
\end{tabular}


As variáveis dependentes utilizadas são relacionadas ao valor da empresa ou ao seu desempenho. Diversas definiçõoes operacionais são utilizadas, a fim de checar a consistência dos resultados. As variáveis dependentes são apresentadas abaixo:

Quadro 4 - variáveis dependentes do estudo: valor da empresa e desempenho

\begin{tabular}{|l|c|}
\hline Descrição & Legenda \\
\hline Q de Tobin & Q \\
\hline Valor da Empresa sobre ativo total (Firm Value / Ativo Total) & FIRMVSAT \\
\hline Retorno sobre ativo do lucro operacional próprio (Lucro Operacional Próprio/Ativo Total) & RSAPR \\
\hline Retorno sobre ativo do lucro operacional (Lucro Operacional /Ativo Total) & RSAOP \\
\hline Retorno sobre Pat. Líquido do lucro operacional próprio (Lucro Oper. Próprio/Pat. Líquido) & RSPLPR \\
\hline Retorno sobre Pat. Líquido do lucro operacional (Lucro Oper. Próprio/Pat. Líquido) & RSPLOP \\
\hline Lucro antes dos juros impostos depreciação e amortização sobre ativo total (LAJIRDA/AT) & EBITSAT \\
\hline
\end{tabular}

Além das variáveis independentes e dependentes, são utilizadas variáveis de controle com o objetivo de isolar sua influência sobre o relacionamento entre as variáveis de interesse mencionadas anteriormente. As variáveis de controle são descritas na seqüência:

Quadro 5 - variáveis de controle do estudo

\begin{tabular}{|l|c|}
\hline Descrição & Legenda \\
\hline Setor de Atuação & SET \\
\hline Liquidez da ação & LIQ \\
\hline Percentual de Ações Ordinárias do(s) Acionista(s) Controlador(es) & ACCONTR \\
\hline Percentual de Ações Ordinárias dos Participantes do Acordo de Acionista & ACAA \\
\hline Ativo Total (valor publicado no balanço patrimonial do respectivo ano) & AT \\
\hline Dívida total sobre ativo total & DIVTSAT \\
\hline Receita Operacional & REC \\
\hline
\end{tabular}

Conforme apresentado nas hipóteses da pesquisa (seção 1.6), pretende-se investigar a suposta existência de um relacionamento significativo entre as variáveis de governança corporativa e desempenho ou valor das empresas da amostra. Ademais, o trabalho pretende avaliar se as empresas que seguem as recomendações dos principais códigos sobre o tema no país (IBGC e CVM) e que são consideradas com melhor estrutura de governança (seção 3.2.2) foram as que obtiveram melhor avaliação de mercado e/ou desempenho no período analisado. Desta forma, os modelos gerais utilizados são: 


$$
V_{i}=\alpha_{1}+\beta_{11} * \operatorname{INDEP}_{i}+\beta_{21} * \log \left(\text { TOT }_{i}\right)+\beta_{31} *\left(\log \left(\text { TOT }_{i}\right)^{2}\right)+\beta_{41} * D E_{i}+\sum_{i=1}^{k} \beta_{i l} * V C_{i}+\varepsilon_{i 1}
$$

e

$$
D_{i}=\alpha_{1}+\beta_{12} * \operatorname{INDEP}_{i}+\beta_{22} * \log \left(\text { TOT }_{i}\right)+\beta_{32} *\left(\log \left(T O T_{i}\right)^{2}\right)+\beta_{42} * D E_{i}+\sum_{i=1}^{k} \beta_{i 2} * V C_{i}+\varepsilon_{i}
$$

Onde:

$\mathrm{V}_{i}$ - variáveis de valor da $i$-ésima empresa: Q ou FIRMVSAT;

$\mathrm{D}_{i}$ - variáveis de desempenho da $i$-ésima empresa: RSAPR, RSAOP, RSPLPR, RSPLOP ou EBITSAT;

$\mathrm{INDEP}_{i}$ - independência do Conselho de Administração da $i$-ésima empresa, conforme definido na seção 3.2.1;

TOT $_{i}$ - tamanho do Conselho de Administração da $i$-ésima empresa;

$\mathrm{DE}_{i}$ - presença de diretor executivo ocupando o cargo de presidente do conselho na $i$-ésima empresa, conforme definido na seção 3.2.1;

$\mathrm{VC}_{i}$ - variáveis de controle da $i$-ésima empresa, descritas no quadro 5;

$\varepsilon_{i}$ - termo de erro que capta o componente não sistemático, isto é, a parcela de V ou D não explicada pelo modelo.

Partindo da hipótese de que a governança corporativa é relevante para o valor ou desempenho corporativo e que as empresas que possuem melhor estrutura de governança (seção 3.2.2) apresentaram melhores resultados no período, espera-se que os valores dos coeficientes $\beta_{11}$ e $\beta_{12}$ sejam positivos e significativos estatisticamente, haja vista a hipótese de que quanto maior a independência do conselho (INDEP), maior o valor da empresa (V) e seu desempenho (D). Com relação ao tamanho do conselho (TOT), a hipótese é de que exista uma faixa ótima para os conselhos com cinco a nove membros. Para captar este comportamento proposto, optou-se por inserir um termo quadrático na variável TOT. Além disso, optou-se por inseri-la em escala logarítmica no modelo, já que a variável é eminentemente discreta e o modelo de regressão pressupõe variáveis contínuas. Para que a hipótese da faixa ótima para o tamanho do conselho se confirme, espera-se que os coeficientes $\beta_{21}, \beta_{22}$ e $\beta_{31}, \beta_{32}$ sejam significativos estatisticamente e tenham sinais positivos e negativos, respectivamente. Por fim, para que se corrobore a hipótese de que é saudável para a empresa a presença de pessoas distintas ocupando os cargos de diretor executivo e presidente do conselho, espera-se 
que os valores dos coeficientes $\beta_{41}$ e $\beta_{42}$ sejam significativos estatisticamente e negativos, apontando para uma relação inversa entre a unificação dos cargos de diretor executivo e presidente do conselho e o valor e desempenho da empresa. Caso os valores de todos os coeficientes acima se mostrem significativos estatisticamente mas com sinal inverso ao proposto, será constatada a relevância da governança corporativa, porém de forma oposta ao recomendado pelos códigos do IBGC e CVM.

A validade das inferências dependerá da qualidade estatística dos modelos adotados, que será avaliada pela sua aderência aos pressupostos de um Modelo de Regressão Linear (MRL) ${ }^{9}$. Para análise dos modelos, serão utilizados, entre outros, o teste de heterocedasticidade de White, o teste de normalidade de resíduos de JarqueBera, o cálculo do Número de Condição, o critério de informação de Schwarz e o Rquadrado ajustado.

\subsection{Definição Teórica e Operacional das Variáveis}

O estudo define governança corporativa pela estrita perspectiva da teoria de agência, com base nas definições teóricas de Shleifer e Vishny (1997), La Porta et al. (2000b) e Jensen (2001) sobre o tema.

Segundo Shleifer e Vishny (1997, p.737),"governança corporativa lida com as maneiras pelas quais os fornecedores de recursos garantem que obterão para si o retorno sobre seu investimento". Outra definição proposta pelos autores (p.743), mais detalhada, é que "governança corporativa é o conjunto de restrições que os gestores aplicam sobre si próprios, ou que os investidores aplicam sobre os gestores, de forma a reduzir a alocação errada de recursos ex post e induzir os investidores a fornecerem mais recursos ex ante".

Segundo La Porta et al. (2000b, p.3), "governança corporativa é o conjunto de mecanismos que protegem os investidores externos da expropriação pelos internos (gestores e acionistas controladores)".

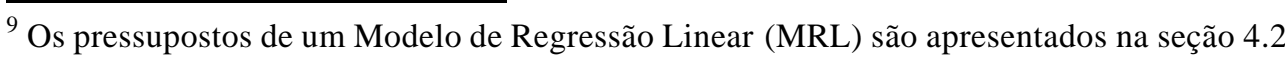


Segundo Jensen (2001, p. 58), "governança é a estrutura de controle de alto nível, consistindo dos direitos de decisão do Conselho de Administração e do diretor executivo, dos procedimentos para alterá-los, do tamanho e composição do Conselho de Administração e da compensação e posse de ações dos gestores e conselheiros".

As definições operacionais das variáveis utilizadas no estudo são:

\subsubsection{Governança Corporativa}

Como parte-se da hipótese de que as características do Conselho de Administração afetam a governança corporativa, para o presente estudo governança é a medida pela qual o Conselho de Administração consegue ser ativo e independente e representar o interesse dos acionistas, incluindo-se os minoritários. Serão utilizadas no estudo três variáveis relacionadas às características do Conselho de Administração:

- presença de diretor executivo ocupando o cargo de presidente do conselho da empresa - é representada por uma variável binária onde:

$\mathrm{DE}=1$, se os cargos de diretor executivo e presidente do conselho forem ocupados pela mesma pessoa, isto é, se os cargos forem unificados;

$\mathrm{DE}=0$, se os cargos forem ocupados por pessoas diferentes.

- independência do Conselho de Administração - é a diferença entre a proporção de membros não executivos (externos) e membros executivos (internos) ${ }^{10}$ no conselho, dada pela equação:

$I N D E P=\left(\frac{E X T}{T O T}\right)-\left(\frac{I N T}{T O T}\right)$

Onde:

INDEP - grau de independência do Conselho de Administração;

TOT - número total de membros do conselho;

EXT - número de membros não executivos da empresa (externos) no conselho;

INT - número de membros executivos da empresa (internos) no conselho.

- $\quad$ tamanho do conselho - é dado pelo total de membros do órgão (TOT).

\footnotetext{
${ }^{10} \mathrm{O}$ Anexo B (glossário) apresenta a definição utilizada na pesquisa para classificação dos conselheiros, dividindo-os em internos, externos e independentes
} 
A seção 2.6 do capítulo "Fundamentação Teórica" explica o racional para escolha destas variáveis como indicadores de governança corporativa das empresas. Essa seção apresenta os aspectos teóricos e evidências empíricas de estudos sobre o tema, justificando academicamente a escolha das variáveis.

\subsubsection{Melhor Estrutura de Governança Corporativa}

Se baseia na hipótese de que empresas com estruturas do Conselho de Administração mais adequadas ao recomendado pelo "Código das Melhores Práticas de Governança Corporativa" do Instituto Brasileiro de Governança Corporativa (IBGC) ${ }^{11} \mathrm{e}$ pela "Cartilha de Governança Corporativa" da Comissão de Valores Mobiliários $(\mathrm{CVM})^{12}$ teriam uma melhor estrutura de governança corporativa. Especificamente, o termo significa:

- pessoas distintas ocupando os cargos de diretor executivo e presidente do Conselho de Administração;

- $\quad$ empresas com maior proporção de membros não executivos no Conselho de Administração;

- $\quad$ tamanho do Conselho de Administração de cinco a nove membros.

A adoção do Código do IBGC e da Cartilha de Governança da CVM ${ }^{13}$ justificam-se por serem os principais documentos sobre o tema no Brasil, tendo sido elaborados a partir dos principais códigos de governança internacionais. Além disso, como as recomendações desses documentos servem como diretrizes para as empresas brasileiras, o teste possui aplicação prática ao checar se as empresas com estas características foram melhor avaliadas pelo mercado ou tiveram melhor desempenho nos últimos anos.

\footnotetext{
${ }^{11} \mathrm{O}$ código de governança do Instituto Brasileiro de Governança Corporativa pode ser encontrado no site: http://www.ibgc.org.br

${ }^{12}$ A Cartilha de governança corporativa da Comissão de Valores Mobiliários, lançada em Junho de 2002, pode ser encontrada no site: http://www.cvm.gov.br

${ }^{13}$ As recomendações originais dos códigos do IBGC e da CVM nos temas escolhidos para a "melhor estrutura de governança corporativa" encontram-se no Anexo C
} 


\subsubsection{Valor de Mercado da Empresa}

Existem várias definições possíveis para este conceito. No estudo serão utilizados os seguintes indicadores:

- "Q de Tobin" - este indicador foi escolhido por ter sido utilizado em vários estudos com testes empíricos sobre governança corporativa, como os de Barnhart e Rosenstein (1998), Bhagat e Black (2002) e Yermack (1996). Tobin (1958) definiu o "Q de Tobin" como:

$$
\text { Q de Tobin }=\frac{\text { Valor de Mercado das Ações }+ \text { Valor de Mercado das Dívidas }}{\text { Valor de Reposição dos Ativos }}
$$

É um indicador cada vez mais utilizado como medida de valor da empresa. Segundo Famá e Barros (2000, p.5), se o Q de Tobin for crescente, há uma indicação de aumento de uso dos recursos e conseqüente lucratividade. Entretanto, é muito difícil calcular o Q de Tobin conforme descrito no artigo original. Com exceção do valor de mercado das ações, diretamente observável pela cotação na bolsa de valores, os outros componentes da fórmula, como o valor de mercado das dívidas e o valor de reposição dos ativos da empresa, não são observáveis diretamente. Na ausência da disponibilidade de medidas diretas, apenas medidas indiretas podem ser estimadas. $\mathrm{O}$ " $\mathrm{Q}$ de Tobin" para empresas brasileiras será estimado pela aproximação simplificada proposta por Chung e Pruitt (1994, p.72), que definem o Q de Tobin como:

$$
\mathrm{Q} \text { de Tobin } \cong \frac{V M A O+V M A P+D I V T}{A T}
$$

Onde:

VMAO - valor de mercado das ações ordinárias;

VMAP - valor de mercado das ações preferenciais;

DIVT - valor contábil das dívidas de curto prazo somado ao valor contábil das dívidas de longo prazo menos o ativo circulante;

AT - ativo total da companhia.

Chung e Pruitt (1994, p.73) testaram a validade dessa fórmula simplificada, comparando os resultados obtidos em diversas empresas com os resultados obtidos nas 
mesmas empresas pelo método de Lindenberg e Ross (1981), mais preciso teoricamente e mais complexo de calcular. Utilizando uma análise de regressão do tipo seção transversal para dez anos, os autores mostram que, no mínimo, 96,6\% da variação total do "Q de Tobin" calculado pelo procedimento de Lindenberg e Ross (1981) é explicada pelo seu método simplificado, demonstrando, assim, sua adequação.

- Valor da Empresa sobre Ativo Total (FIRMVSAT) - este indicador procura ser uma alternativa ao $\mathrm{Q}$ de Tobin, sendo calculado pela equação:

$$
\text { FIRMVSAT }=\frac{\text { FirmValue }}{A T}
$$

Onde:

Firm Value - indicador calculado pelo sistema de informações Economática Ltda pela equação:

Firm Value $=$ Cotação*Total de Ações + Debêntures CP e LP + Financiamentos CP e LP + Adiantamentos Contratos de Câmbio - Disponibilidades e Investimentos de Curto Prazo;

AT - ativo total da empresa.

\subsubsection{Desempenho}

É o resultado financeiro com base em informações contábeis da empresa. Serão utilizados cinco indicadores diferentes:

- RSAPR - é o retorno sobre o ativo do lucro operacional próprio. É calculado por:

$$
\text { RSAPR }=\frac{\text { Lucro Operacional Próprio }}{\text { Ativo Total }}
$$

O lucro operacional próprio é o lucro operacional antes das receitas e despesas financeiras.

- $\quad$ RSAOP - é o retorno sobre o ativo do lucro operacional. É calculado por:

$$
\text { RSAOP }=\frac{\text { Lucro Operacional }}{\text { Ativo Total }}
$$


- $\quad$ RSPLPR - é o retorno sobre o patrimônio líquido do lucro operacional próprio. É calculado por:

$$
\text { RSPLPR }=\frac{\text { Lucro Operacional Próprio }}{\text { PatrimônioLíquido }}
$$

- RSPLOP - é o retorno sobre o patrimônio líquido do lucro operacional. É calculado por:

$$
\text { RSPLOP }=\frac{\text { Lucro Operacional }}{\text { PatrimônioLíquido }}
$$

- EBITSAT - é o lucro antes dos juros, impostos, depreciação e amortização (LAJIRDA) sobre o ativo total. É calculado por:

$$
\text { EBITSAT }=\frac{\text { LAJIRDA }}{\text { Ativo Total }}
$$

\subsubsection{Variáveis de Controle}

As variáveis de controle foram selecionadas com base na influência que exercem sobre as variáveis dependentes ( $\mathrm{V}$ e $\mathrm{D}$ ) e independentes (INDEP, TOT e DE). Caso as variáveis de controle (que são variáveis independentes) possuam correlação forte com algumas destas variáveis e sejam omitidas do modelo, a relação entre as variáveis desejadas para análise pode não ser evidenciada de forma correta. As principais variáveis de controle do estudo são as relacionadas à estrutura de propriedade e ao setor de atuação da companhia.

\subsubsection{Estrutura de Propriedade}

Segundo Hermalin e Weisbach (2001, p.31), a estrutura de propriedade da empresa afeta sua governança corporativa, já que uma empresa com estrutura de propriedade extremamente pulverizada tende a ter composição do conselho e relações de agência distintas de uma empresa com estrutura de propriedade concentrada. Um dos principais componentes para análise da estrutura de propriedade é a presença ou não de 
um acionista controlador. Portanto, três variáveis relacionadas à presença de um acionista controlador ou grupo de acionistas participantes de acordo de acionistas são consideradas:

- percentual de ações ordinárias do acionista controlador - soma do percentual de ações ordinárias do(s) acionista(s) controlador(es) da empresa;

- presença de acordo de acionistas - é representado por uma variável binária onde:

$\mathrm{AA}=1$, caso a empresa possua acordo de acionistas;

$\mathrm{AA}=0$, caso a empresa não possua acordo de acionistas.

- percentual de ações ordinárias dos participantes do acordo de acionistas - soma do percentual de ações ordinárias do(s) acionista(s) pertencente(s) ao acordo de acionistas. Caso a empresa não possua acordo de acionistas, é igual ao percentual de ações ordinárias do(s) controlador(es).

\subsubsection{Setor de Atuação}

O setor de atuação pode influenciar principalmente as variáveis dependentes de valor da empresa e desempenho, já que no período analisado alguns setores podem ter apresentado resultados sistematicamente melhores, em média, do que outros. Como forma de mitigar esta situação, foram utilizadas variáveis binárias para representar os diferentes setores. Estas variáveis atribuem valor 1 para as empresas pertencentes a um dos setores em específico e 0 para as empresas pertencentes aos demais setores. Foi adotado o critério do Standard Industrial Code (SIC) americano do tipo Division para classificação das empresas. Esta classificação é feita pelo sistema de informações Economática, que fornece a relação das empresas e dos seus respectivos setores. É uma classificação ampla, que divide as empresas em seis categorias:

- comércio atacadista (comatac);

- comércio varejista (comvar);

- construção (constr);

- manufaturados (manuf);

- mineração (miner);

- serviços de transporte, comunicação, eletricidade (serv). 


\subsection{População, Amostragem e Coleta dos Dados}

A amostra da análise é composta por todas companhias abertas não financeiras negociadas na Bolsa de Valores de São Paulo (Bovespa) e na Sociedade Operadora de Mercado de Ativos (SOMA) que apresentaram liquidez significativa nos anos de 1998, 1999, 2000. Para o presente estudo, entende-se como empresas com liquidez significativa as empresas que apresentaram índice de liquidez anual maior que $0,001 \%$ do índice da empresa com maior liquidez no respectivo ano. A escolha desta faixa de corte para a definição da amostra, ao invés da coleta de dados de todas as companhias abertas, se deve ao fato de que as empresas com liquidez muito baixa possuem uma probabilidade menor de terem suas cotações adequadas ao valor de mercado. A fórmula utilizada para o cálculo da liquidez das ações (LQ) é a utilizada pelo sistema de informações Economática Ltda, de cuja base de dados foi extraída parte dos dados da pesquisa. A liquidez é dada por:

$$
L Q=100 \times\left(\frac{p}{\mathrm{P}}\right) \times \sqrt{\left(\frac{n}{N}\right) \times\left(\frac{v}{V}\right)}
$$

Onde:

LQ - índice de liquidez da ação;

$p$ - número de dias em que houve ao menos um negócio com a ação no período analisado;

$\mathrm{P}$ - número total de dias do período analisado;

$n$ - número de negócios com a ação no período analisado;

$\mathrm{N}$ - número de negócios com todas as ações no período analisado;

$v$ - volume em dinheiro negociado com a ação no período analisado;

V - volume em dinheiro negociado com todas as ações no período analisado.

Após a aplicação do critério de liquidez mínima para definição da amostra da pesquisa, obteve-se 218 empresas nos anos de 1999 e 1998 e 215 empresas no ano de 2000. Esta amostra possui um tamanho significativo em relação ao total de empresas listadas na Bolsa de Valores de São Paulo ${ }^{14}$, podendo considerá-la como representativa das companhias abertas listadas. Entretanto, segundo Martins (1994, p.40), quando a 
amostra da pesquisa é selecionada a partir de um critério definido pelo pesquisador, não será possível generalizar os resultados para a população, já que as amostras não probabilísticas não garantem sua representatividade. No caso da pesquisa, a própria escolha de um janela temporal nos anos de 1998, 1999 e 2000 já representa uma amostragem intencional, haja vista que o objetivo é obter uma relação entre governança e valor ou desempenho corporativo para as empresas não apenas nestes anos. O segundo procedimento de amostragem intencional, do critério da liquidez mínima, apenas procurou deixar de fora as empresas com liquidez tão baixa que não poderiam ser consideradas válidas para o teste por não terem seus valores de mercado refletidos nos preços das suas ações. Como forma de contornar esta situação e dar um caráter pseudoaleatório às amostras, foram sorteadas aleatoriamente amostras de 120 empresas para cada ano, nos anos de 1998, 1999 e 2000, para o qual foram feitos os testes.

Durante a coleta dos dados, algumas empresas não apresentaram dados suficientes para a confecção de todas as variáveis, reduzindo o tamanho da amostra para 200 empresas nos anos de 1998 e 1999 e para 194 empresas no ano de 2000. No total, foram coletados dados de 594 empresas. Os mesmos testes foram repetidos para cada ano, com objetivo de checar a persistência dos resultados.

Foram utilizados dados secundários referentes ao valor de mercado das ações, informações contábeis, variáveis de governança e demais variáveis de controle. Estas informações foram disponibilizadas pelos sistemas de informações Economática Ltda, Bloomberg e Divulgação Externa ITR/DFP/IAN (DIVEXT) da Comissão de Valores Mobiliários. A coleta dos dados foi dividida da seguinte forma:

Quadro 6 - sistemas de informações utilizados no estudo

\begin{tabular}{|c|l|}
\hline Sistema de Informações & Dados Coletados \\
\hline \multirow{3}{*}{ DIVEXT - Divulgação Externa } & - Número de membros do conselho (tamanho); \\
& - Número de executivos no conselho; \\
& - Número de não- executivos no conselho; \\
& - Presença de acordo de acionistas; \\
& - Percentual de ações do acionista controlador; \\
& - Percentual de ações dos participantes do acordo de acionistas. \\
\hline
\end{tabular}

\footnotetext{
${ }^{14}$ Em junho de 2002 havia 410 empresas listadas na Bolsa de Valores de São Paulo
} 


\begin{tabular}{|l|l|}
\hline & - Índice de liquidez; \\
& - Setor de atuação; \\
& - Dados contábeis - Balanço Patrimonial e Demonstrativo de \\
& Resultados; \\
Economática & - Índice de Pay Out; \\
& - Firm Value. \\
\hline Bloomberg & - Valor de mercado das ações. \\
\hline
\end{tabular}

Os dados de governança e de estrutura de propriedade coletados no sistema DIVEXT da Comissão de Valores Mobiliários foram estruturados em planilhas eletrônicas distintas para cada ano analisado. Como exemplo, segue abaixo a planilha com os dados referentes ao ano de 2000:

Quadro 7 - dados de governança e estrutura de propriedade das empresas em 2000

\begin{tabular}{|c|c|c|c|c|c|c|c|c|}
\hline Empresas & DE é PC? & TOT & INT & EXT & INDEP & $\begin{array}{c}\text { Acordo } \\
\text { Acionista? }\end{array}$ & $\%$ ACContr & $\%$ AcAA \\
\hline Acesita & Não & $\overline{9}$ & 1 & 8 & 0.78 & Sim & $75.7 \%$ & $75.7 \%$ \\
\hline Acos Villares & Não & 7 & 1 & 6 & 0.71 & Sim & $58.4 \%$ & $87.3 \%$ \\
\hline Adubos Trevo & Não & 5 & 0 & 5 & 1.00 & Não & $51.0 \%$ & $51.0 \%$ \\
\hline Albarus & Não & 3 & 1 & 2 & 0.33 & Não & $84.2 \%$ & $84.2 \%$ \\
\hline Alpargatas & Não & 5 & 1 & 4 & 0.60 & Não & $72.9 \%$ & $72.9 \%$ \\
\hline Amadeo Rossi & Não & 3 & 1 & 2 & 0.33 & Não & $65.9 \%$ & $65.9 \%$ \\
\hline Ambev & Não & 7 & 0 & 7 & 1.00 & Sim & $68.8 \%$ & $68.8 \%$ \\
\hline Antarctica Nord & Não & 3 & 0 & 3 & 1.00 & Não & $74.8 \%$ & $74.8 \%$ \\
\hline Aracruz & Não & 10 & 0 & 10 & 1.00 & Sim & $96.5 \%$ & $96.5 \%$ \\
\hline Avipal & Sim & 4 & 1 & 3 & 0.50 & Não & $71.5 \%$ & $71.5 \%$ \\
\hline Bahia Sul & Não & 6 & 0 & 6 & 1.00 & Sim & $93.7 \%$ & $100.0 \%$ \\
\hline Bardella & Sim & 4 & 1 & 3 & 0.50 & Não & $45.0 \%$ & $45.0 \%$ \\
\hline Belgo Mineira & Não & 8 & 1 & 7 & 0.75 & Não & $59.3 \%$ & $59.3 \%$ \\
\hline Bic Caloi & Sim & 3 & 1 & 2 & 0.33 & Não & $77.0 \%$ & $77.0 \%$ \\
\hline Biobras & Não & 5 & 0 & 5 & 1.00 & Não & $74.2 \%$ & $74.2 \%$ \\
\hline Bombril & Sim & 6 & 1 & 5 & 0.67 & Não & $100.0 \%$ & $100.0 \%$ \\
\hline Bompreco & Não & 3 & 1 & 2 & 0.33 & Não & $100.0 \%$ & $100.0 \%$ \\
\hline Brasil T Par & Não & 6 & 0 & 6 & 1.00 & Não & $52.3 \%$ & $52.3 \%$ \\
\hline Brasil Telec & Não & 7 & 0 & 7 & 1.00 & Não & $98.7 \%$ & $98.7 \%$ \\
\hline Brasilit & Não & 7 & 2 & 5 & 0.43 & Não & $92.6 \%$ & $92.6 \%$ \\
\hline Brasmotor & Sim & 4 & 1 & 3 & 0.50 & Não & $60.0 \%$ & $60.0 \%$ \\
\hline Brazil Realt & Sim & 8 & 2 & 6 & 0.50 & Não & $50.0 \%$ & $50.0 \%$ \\
\hline Bunge Alimentos & Não & 9 & 2 & 7 & 0.56 & Não & $79.1 \%$ & $79.1 \%$ \\
\hline Cach Dourada & Não & 3 & 0 & 3 & 1.00 & Não & $94.3 \%$ & $94.3 \%$ \\
\hline Cacique & Não & 6 & 2 & 4 & 0.33 & Não & $50.6 \%$ & $50.6 \%$ \\
\hline Caemi Metal & Não & 10 & 2 & 8 & 0.60 & Sim & $100.0 \%$ & $100.0 \%$ \\
\hline Cambuci & Sim & 7 & 2 & 5 & 0.43 & Não & $51.0 \%$ & $51.0 \%$ \\
\hline CEB & Sim & 9 & 1 & 8 & 0.78 & Não & $89.3 \%$ & $89.3 \%$ \\
\hline CEEE Energia & Não & 8 & 1 & 7 & 0.75 & Sim & $67.0 \%$ & $99.7 \%$ \\
\hline Celesc & Sim & 11 & 1 & 10 & 0.82 & Não & $50.2 \%$ & $50.2 \%$ \\
\hline Celpe & Não & 5 & 0 & 5 & 1.00 & Não & $94.9 \%$ & $94.9 \%$ \\
\hline Cemig & Sim & 11 & 1 & 10 & 0.82 & Não & $51.0 \%$ & $51.0 \%$ \\
\hline
\end{tabular}




\begin{tabular}{|c|c|c|c|c|c|c|c|c|}
\hline Empresas & DE é PC? & TOT & INT & EXT & INDEP & $\begin{array}{c}\text { Acordo } \\
\text { Acionista? }\end{array}$ & $\%$ ACContr & $\%$ AcAA \\
\hline Cerj & Não & 5 & 0 & 5 & 1.00 & Sim & $95.0 \%$ & $95.0 \%$ \\
\hline Cesp & Não & 16 & 0 & 16 & 1.00 & Não & $83.7 \%$ & $83.7 \%$ \\
\hline Cia Hering & Não & 9 & 2 & 7 & 0.56 & Não & $51.2 \%$ & $51.2 \%$ \\
\hline Ciquine & Não & 4 & 0 & 4 & 1.00 & Sim & $87.9 \%$ & $87.9 \%$ \\
\hline Coelba & Não & 6 & 0 & 6 & 1.00 & Não & $89.8 \%$ & $89.8 \%$ \\
\hline Coelce & Não & 11 & 0 & 11 & 1.00 & Não & $91.7 \%$ & $91.7 \%$ \\
\hline Comgas & Sim & 8 & 2 & 6 & 0.50 & Não & $76.1 \%$ & $76.1 \%$ \\
\hline Confab & Sim & 8 & 2 & 6 & 0.50 & Não & $99.2 \%$ & $99.2 \%$ \\
\hline Copel & Não & 9 & 1 & 8 & 0.78 & Não & $58.6 \%$ & $58.6 \%$ \\
\hline Copene & Não & 11 & 1 & 10 & 0.82 & Sim & $58.4 \%$ & $70.0 \%$ \\
\hline Coteminas & Sim & 12 & 4 & 8 & 0.33 & Sim & $51.4 \%$ & $52.4 \%$ \\
\hline Cremer & Não & 10 & 0 & 10 & 1.00 & Não & $24.0 \%$ & $24.0 \%$ \\
\hline CRT Celular & Não & 5 & 1 & 4 & 0.60 & Sim & $80.2 \%$ & $80.2 \%$ \\
\hline Dimed & Não & 3 & 1 & 2 & 0.33 & Não & $22.8 \%$ & $22.8 \%$ \\
\hline Dixie Toga & Não & 6 & 0 & 6 & 1.00 & Sim & $88.6 \%$ & $88.6 \%$ \\
\hline Docas & Não & 5 & 0 & 5 & 1.00 & Não & $68.0 \%$ & $68.0 \%$ \\
\hline Duratex & Não & 11 & 1 & 10 & 0.82 & Não & $84.5 \%$ & $84.5 \%$ \\
\hline EBE & Não & 5 & 0 & 5 & 1.00 & Sim & $97.8 \%$ & $97.8 \%$ \\
\hline Eberle & Sim & 3 & 1 & 2 & 0.33 & Não & $93.3 \%$ & $93.3 \%$ \\
\hline EDN & Sim & 5 & 1 & 4 & 0.60 & Sim & $100.0 \%$ & $100.0 \%$ \\
\hline Electrolux & Não & 5 & 0 & 5 & 1.00 & Não & $99.9 \%$ & $99.9 \%$ \\
\hline Elektro & Sim & 7 & 3 & 4 & 0.14 & Não & $90.0 \%$ & $90.0 \%$ \\
\hline Eletrobras & Sim & 9 & 1 & 8 & 0.78 & Não & $58.4 \%$ & $58.4 \%$ \\
\hline Eletropaulo Metrop & Sim & 9 & 3 & 6 & 0.33 & Não & $31.0 \%$ & $31.0 \%$ \\
\hline EMAE & Não & 16 & 0 & 16 & 1.00 & Não & $97.4 \%$ & $97.4 \%$ \\
\hline Embraco & Não & 4 & 1 & 3 & 0.50 & Não & $97.0 \%$ & $97.0 \%$ \\
\hline Embraer & Não & 13 & 1 & 12 & 0.85 & Sim & $64.4 \%$ & $64.4 \%$ \\
\hline Enersul & Não & 7 & 0 & 7 & 1.00 & Não & $87.9 \%$ & $87.9 \%$ \\
\hline EPTE & Não & 15 & 0 & 15 & 1.00 & Não & $49.0 \%$ & $49.0 \%$ \\
\hline Escelsa & Não & 9 & 0 & 9 & 1.00 & Sim & $77.3 \%$ & $77.3 \%$ \\
\hline Estrela & Sim & 3 & 1 & 2 & 0.33 & Não & $94.7 \%$ & $94.7 \%$ \\
\hline Eternit & Não & 6 & 0 & 6 & 1.00 & Sim & $64.7 \%$ & $64.7 \%$ \\
\hline Eucatex & Sim & 5 & 2 & 3 & 0.20 & Não & $55.6 \%$ & $55.6 \%$ \\
\hline F Cataguazes & Não & 7 & 0 & 7 & 1.00 & Sim & $51.0 \%$ & $81.8 \%$ \\
\hline Ferbasa & Não & 6 & 2 & 4 & 0.33 & Não & $98.8 \%$ & $98.8 \%$ \\
\hline Ferro Ligas & Não & 3 & 1 & 2 & 0.33 & Não & $99.9 \%$ & $99.9 \%$ \\
\hline Fertibras & Sim & 7 & 2 & 5 & 0.43 & Sim & $73.0 \%$ & $100.0 \%$ \\
\hline Fertiza & Sim & 4 & 1 & 3 & 0.50 & Não & $99.9 \%$ & $99.9 \%$ \\
\hline Forjas Taurus & Sim & 6 & 2 & 4 & 0.33 & Não & $83.9 \%$ & $83.9 \%$ \\
\hline Fosfertil & Não & 9 & 0 & 9 & 1.00 & Não & $69.9 \%$ & $69.9 \%$ \\
\hline Fras-Le & Sim & 5 & 1 & 4 & 0.60 & Não & $53.1 \%$ & $53.1 \%$ \\
\hline Ger Paranapanema & Sim & 5 & 1 & 4 & 0.60 & Não & $93.1 \%$ & $93.1 \%$ \\
\hline Geradora Tiete & Sim & 9 & 3 & 6 & 0.33 & Não & $71.6 \%$ & $71.6 \%$ \\
\hline Gerasul & Não & 7 & 1 & 6 & 0.71 & Não & $77.5 \%$ & $77.5 \%$ \\
\hline Gerdau Met & Sim & 3 & 1 & 2 & 0.33 & Não & $71.8 \%$ & $71.8 \%$ \\
\hline Gerdau & Sim & 3 & 1 & 2 & 0.33 & Não & $83.0 \%$ & $83.0 \%$ \\
\hline Globex & Não & 4 & 1 & 3 & 0.50 & Não & $96.0 \%$ & $96.0 \%$ \\
\hline Globo Cabo & Não & 8 & 1 & 7 & 0.75 & Sim & $56.7 \%$ & $96.5 \%$ \\
\hline Gradiente & Sim & 9 & 3 & 6 & 0.33 & Não & $77.4 \%$ & $77.4 \%$ \\
\hline Grazziotin & Sim & 7 & 2 & 5 & 0.43 & Não & $57.3 \%$ & $57.3 \%$ \\
\hline Guararapes & Sim & 3 & 1 & 2 & 0.33 & Não & $68.1 \%$ & $68.1 \%$ \\
\hline
\end{tabular}




\begin{tabular}{|c|c|c|c|c|c|c|c|c|}
\hline Empresas & DE é PC? & TOT & INT & EXT & INDEP & $\begin{array}{c}\text { Acordo } \\
\text { Acionista? }\end{array}$ & $\%$ ACContr & $\%$ AcAA \\
\hline Inds Romi & Sim & $\overline{9}$ & 3 & 6 & 0.33 & Sim & $60.6 \%$ & $60.6 \%$ \\
\hline Inepar Energia & Não & 9 & 1 & 8 & 0.78 & Sim & $60.0 \%$ & $73.3 \%$ \\
\hline Inepar & Sim & 15 & 2 & 13 & 0.73 & Não & $60.7 \%$ & $60.7 \%$ \\
\hline lochp-Maxion & Não & 8 & 0 & 8 & 1.00 & Sim & $78.5 \%$ & $86.2 \%$ \\
\hline Ipiranga Dist & Sim & 5 & 1 & 4 & 0.60 & Não & $32.4 \%$ & $32.4 \%$ \\
\hline Ipiranga Petroleo & Sim & 5 & 1 & 4 & 0.60 & Não & $62.9 \%$ & $62.9 \%$ \\
\hline Ipiranga Ref & Não & 5 & 1 & 4 & 0.60 & Sim & $23.5 \%$ & $23.5 \%$ \\
\hline Iven & Não & 8 & 1 & 7 & 0.75 & Não & $70.0 \%$ & $70.0 \%$ \\
\hline J B Duarte & Sim & 4 & 1 & 3 & 0.50 & Não & $94.0 \%$ & $94.0 \%$ \\
\hline Karsten & Não & 10 & 2 & 8 & 0.60 & Não & $75.9 \%$ & $75.9 \%$ \\
\hline Kepler Weber & Não & 5 & 1 & 4 & 0.60 & Não & $74.7 \%$ & $74.7 \%$ \\
\hline Klabin & Não & 10 & 0 & 10 & 1.00 & Não & $57.7 \%$ & $57.7 \%$ \\
\hline Kuala & Não & 3 & 0 & 3 & 1.00 & Sim & $53.9 \%$ & $53.9 \%$ \\
\hline Latasa & Não & 5 & 0 & 5 & 1.00 & Sim & $91.4 \%$ & $91.4 \%$ \\
\hline Light & Não & 6 & 1 & 5 & 0.67 & Sim & $50.9 \%$ & $50.9 \%$ \\
\hline LightPar & Não & 6 & 1 & 5 & 0.67 & Não & $81.6 \%$ & $81.6 \%$ \\
\hline Lix da Cunha & Sim & 3 & 1 & 2 & 0.33 & Não & $89.8 \%$ & $89.8 \%$ \\
\hline Loj Americanas & Não & 4 & 1 & 3 & 0.50 & Não & $48.2 \%$ & $48.2 \%$ \\
\hline Magnesita & Sim & 7 & 2 & 5 & 0.43 & Não & $65.0 \%$ & $65.0 \%$ \\
\hline Mangels & Sim & 4 & 1 & 3 & 0.50 & Não & $99.9 \%$ & $99.9 \%$ \\
\hline Marcopolo & Sim & 7 & 3 & 4 & 0.14 & Sim & $56.3 \%$ & $56.3 \%$ \\
\hline Metal Leve & Não & 4 & 0 & 4 & 1.00 & Não & $82.2 \%$ & $82.2 \%$ \\
\hline Metisa & Sim & 7 & 2 & 5 & 0.43 & Não & $99.5 \%$ & $99.5 \%$ \\
\hline Millennium & Sim & 3 & 1 & 2 & 0.33 & Não & $99.0 \%$ & $99.0 \%$ \\
\hline Minupar & Sim & 4 & 1 & 3 & 0.50 & Não & $85.9 \%$ & $85.9 \%$ \\
\hline Mont Aranha & Não & 12 & 3 & 9 & 0.50 & Não & $49.1 \%$ & $49.1 \%$ \\
\hline Nitrocarbono & Não & 8 & 2 & 6 & 0.50 & Sim & $95.5 \%$ & $98.6 \%$ \\
\hline Oxiteno & Sim & 6 & 1 & 5 & 0.67 & Não & $65.4 \%$ & $65.4 \%$ \\
\hline Pao de Acucar & Sim & 15 & 3 & 12 & 0.60 & Sim & $60.4 \%$ & $94.9 \%$ \\
\hline Paraibuna & Não & 8 & 0 & 8 & 1.00 & Não & $99.9 \%$ & $99.9 \%$ \\
\hline Paranapanema & Não & 8 & 0 & 8 & 1.00 & Não & $55.5 \%$ & $55.5 \%$ \\
\hline Paul F Luz & Não & 13 & 0 & 13 & 1.00 & Não & $94.9 \%$ & $94.9 \%$ \\
\hline Perdigao & Não & 7 & 0 & 7 & 1.00 & Sim & $90.4 \%$ & $80.3 \%$ \\
\hline Petrobras Distrib & Não & 8 & 0 & 8 & 1.00 & Não & $99.9 \%$ & $99.9 \%$ \\
\hline Petrobras & Não & 7 & 1 & 6 & 0.71 & Não & $55.7 \%$ & $55.7 \%$ \\
\hline Petroflex & Não & 9 & 1 & 8 & 0.78 & Sim & $50.4 \%$ & $50.4 \%$ \\
\hline Petroq.Uniao & Não & 9 & 0 & 9 & 1.00 & Sim & $77.5 \%$ & $57.3 \%$ \\
\hline Petroquisa & Não & 4 & 0 & 4 & 1.00 & Não & $100.0 \%$ & $100.0 \%$ \\
\hline Pettenati & Sim & 3 & 1 & 2 & 0.33 & Não & $96.8 \%$ & $96.8 \%$ \\
\hline Polar & Não & 3 & 0 & 3 & 1.00 & Não & $97.3 \%$ & $97.3 \%$ \\
\hline Polialden & Sim & 6 & 1 & 5 & 0.67 & Sim & $66.7 \%$ & $66.7 \%$ \\
\hline Polipropileno & Não & 5 & 1 & 4 & 0.60 & Não & $75.2 \%$ & $75.2 \%$ \\
\hline Politeno & Não & 7 & 0 & 7 & 1.00 & Sim & $100.0 \%$ & $100.0 \%$ \\
\hline Portobello & Não & 9 & 3 & 6 & 0.33 & Não & $75.6 \%$ & $75.6 \%$ \\
\hline Pronor & Não & 7 & 1 & 6 & 0.71 & Sim & $57.7 \%$ & $100.0 \%$ \\
\hline Randon Part & Sim & 5 & 1 & 4 & 0.60 & Não & $77.4 \%$ & $77.4 \%$ \\
\hline Recrusul & Sim & 7 & 1 & 6 & 0.71 & Não & $77.8 \%$ & $77.8 \%$ \\
\hline Ren Hermann & Sim & 3 & 1 & 2 & 0.33 & Não & $59.1 \%$ & $59.1 \%$ \\
\hline Rhodia-Ster & Sim & 3 & 3 & 0 & -1.00 & Não & $88.5 \%$ & $88.5 \%$ \\
\hline Ripasa & Sim & 6 & 1 & 5 & 0.67 & Sim & $98.0 \%$ & $98.0 \%$ \\
\hline Rossi Resid & Sim & 7 & 2 & 5 & 0.43 & Não & $69.5 \%$ & $69.5 \%$ \\
\hline
\end{tabular}




\begin{tabular}{|c|c|c|c|c|c|c|c|c|}
\hline Empresas & DE é PC? & TOT & INT & EXT & INDEP & $\begin{array}{c}\text { Acordo } \\
\text { Acionista? }\end{array}$ & $\%$ ACContr & $\%$ AcAA \\
\hline Sabesp & Não & 8 & 1 & 7 & 0.75 & Não & $85.3 \%$ & $85.3 \%$ \\
\hline Sadia SA & Não & 11 & 1 & 10 & 0.82 & Sim & $27.8 \%$ & $27.8 \%$ \\
\hline Saint Gobain Canal & Não & 6 & 1 & 5 & 0.67 & Não & $64.1 \%$ & $64.1 \%$ \\
\hline Sansuy & Sim & 6 & 1 & 5 & 0.67 & Não & $73.7 \%$ & $73.7 \%$ \\
\hline Santista Textil & Não & 8 & 0 & 8 & 1.00 & Sim & $99.9 \%$ & $99.9 \%$ \\
\hline Saraiva Livr & Sim & 3 & 1 & 2 & 0.33 & Não & $67.9 \%$ & $67.9 \%$ \\
\hline Schulz & Sim & 6 & 3 & 3 & 0.00 & Não & $99.7 \%$ & $99.7 \%$ \\
\hline Seara Alim & Não & 7 & 1 & 6 & 0.71 & Não & $71.5 \%$ & $71.5 \%$ \\
\hline Serrana & Não & 6 & 1 & 5 & 0.67 & Não & $84.8 \%$ & $84.8 \%$ \\
\hline Sibra & Não & 3 & 1 & 2 & 0.33 & Não & $100.0 \%$ & $100.0 \%$ \\
\hline Sid Nacional & Não & 9 & 0 & 9 & 1.00 & Sim & $46.5 \%$ & $56.8 \%$ \\
\hline Sid Tubarao & Não & 8 & 0 & 8 & 1.00 & Sim & $84.9 \%$ & $84.9 \%$ \\
\hline Sola & Não & 5 & 0 & 5 & 1.00 & Sim & $100.0 \%$ & $100.0 \%$ \\
\hline Solorrico & Sim & 5 & 1 & 4 & 0.60 & Não & $94.7 \%$ & $94.7 \%$ \\
\hline Souza Cruz & Não & 10 & 2 & 8 & 0.60 & Não & $75.3 \%$ & $75.3 \%$ \\
\hline Supergasbras & Não & 4 & 1 & 3 & 0.50 & Não & $92.7 \%$ & $92.7 \%$ \\
\hline Suzano & Não & 7 & 2 & 5 & 0.43 & Não & $100.0 \%$ & $100.0 \%$ \\
\hline Tectoy & Não & 3 & 1 & 2 & 0.33 & Não & $90.1 \%$ & $90.1 \%$ \\
\hline Teka & Não & 6 & 1 & 5 & 0.67 & Não & $90.0 \%$ & $90.0 \%$ \\
\hline Telasa Celular & Não & 5 & 0 & 5 & 1.00 & Não & $97.4 \%$ & $97.4 \%$ \\
\hline Tele Celular Sul & Não & 3 & 0 & 3 & 1.00 & Não & $51.4 \%$ & $51.4 \%$ \\
\hline Tele Centroeste Cel & Não & 7 & 1 & 6 & 0.71 & Não & $53.8 \%$ & $53.8 \%$ \\
\hline Tele Leste Celular & Sim & 4 & 2 & 2 & 0.00 & Não & $58.3 \%$ & $58.3 \%$ \\
\hline Tele Nordeste Celul & Não & 3 & 0 & 3 & 1.00 & Não & $51.2 \%$ & $51.2 \%$ \\
\hline Tele Norte Celular & Sim & 11 & 1 & 10 & 0.82 & Não & $51.8 \%$ & $51.8 \%$ \\
\hline Tele Sudeste Celula & Não & 8 & 1 & 7 & 0.75 & Não & $84.0 \%$ & $84.0 \%$ \\
\hline Telebahia & Não & 5 & 1 & 4 & 0.60 & Não & $95.8 \%$ & $95.8 \%$ \\
\hline Telebrasilia Cel & Não & 5 & 1 & 4 & 0.60 & Não & $90.9 \%$ & $90.9 \%$ \\
\hline Teleceara Celular & Não & 5 & 0 & 5 & 1.00 & Não & $85.3 \%$ & $85.3 \%$ \\
\hline Telegoias Celular & Não & 5 & 1 & 4 & 0.60 & Não & $91.2 \%$ & $91.2 \%$ \\
\hline Telemar & Não & 6 & 2 & 4 & 0.33 & Sim & $50.1 \%$ & $80.1 \%$ \\
\hline Telemig Celul Part & Sim & 11 & 1 & 10 & 0.82 & Não & $51.8 \%$ & $51.8 \%$ \\
\hline Telemig Celular & Não & 5 & 0 & 5 & 1.00 & Não & $89.2 \%$ & $89.2 \%$ \\
\hline Telemig & Não & 5 & 1 & 4 & 0.60 & Não & $89.2 \%$ & $89.2 \%$ \\
\hline Telepar Celular & Não & 5 & 1 & 4 & 0.60 & Não & $87.4 \%$ & $87.4 \%$ \\
\hline Telepisa Celular & Não & 5 & 0 & 5 & 1.00 & Não & $97.9 \%$ & $97.9 \%$ \\
\hline Telerj & Não & 5 & 1 & 4 & 0.60 & Não & $95.8 \%$ & $95.8 \%$ \\
\hline Telern Celular & Não & 5 & 0 & 5 & 1.00 & Não & $92.6 \%$ & $92.6 \%$ \\
\hline Telesc Celular & Sim & 5 & 1 & 4 & 0.60 & Não & $91.6 \%$ & $91.6 \%$ \\
\hline Telesp Cel Part & Não & 19 & 5 & 14 & 0.47 & Não & $85.1 \%$ & $85.1 \%$ \\
\hline Telesp Operac & Sim & 14 & 2 & 12 & 0.71 & Não & $84.3 \%$ & $84.3 \%$ \\
\hline Telma Celular & Sim & 3 & 1 & 2 & 0.33 & Não & $89.8 \%$ & $89.8 \%$ \\
\hline Telpa Celular & Não & 5 & 0 & 5 & 1.00 & Não & $95.1 \%$ & $95.1 \%$ \\
\hline Telpe Celular & Não & 5 & 0 & 5 & 1.00 & Não & $95.1 \%$ & $95.1 \%$ \\
\hline Trafo & Sim & 9 & 2 & 7 & 0.56 & Não & $52.6 \%$ & $52.6 \%$ \\
\hline Transbrasil & Sim & 7 & 2 & 5 & 0.43 & Não & $51.0 \%$ & $51.0 \%$ \\
\hline Transmissao Paulist & Não & 16 & 0 & 16 & 1.00 & Não & $60.5 \%$ & $60.5 \%$ \\
\hline Trikem & Sim & 6 & 1 & 5 & 0.67 & Não & $64.4 \%$ & $64.4 \%$ \\
\hline Ultrapar & Sim & 6 & 2 & 4 & 0.33 & Não & $69.5 \%$ & $69.5 \%$ \\
\hline Unipar & Não & 5 & 1 & 4 & 0.60 & Não & $52.0 \%$ & $52.0 \%$ \\
\hline Usiminas & Não & 10 & 1 & 9 & 0.80 & Sim & $46.3 \%$ & $46.3 \%$ \\
\hline
\end{tabular}




\begin{tabular}{|l|c|c|c|c|c|c|c|c|}
\hline Empresas & DE é PC? & TOT & INT & EXT & INDEP & $\begin{array}{c}\text { Acordo } \\
\text { Acionista? }\end{array}$ & \% ACContr & $\%$ AcAA \\
\hline Usin C Pinto & Sim & 7 & 2 & 5 & 0.43 & Sim & $99.9 \%$ & $99.9 \%$ \\
\hline Vale Rio Doce & Não & 9 & 0 & 9 & 1.00 & Não & $42.2 \%$ & $42.2 \%$ \\
\hline Varig & Não & 7 & 1 & 6 & 0.71 & Não & $87.3 \%$ & $87.3 \%$ \\
\hline Vigor & Sim & 3 & 1 & 2 & 0.33 & Não & $98.2 \%$ & $98.2 \%$ \\
\hline Votorantim C P & Não & 7 & 2 & 5 & 0.43 & Não & $89.0 \%$ & $89.0 \%$ \\
\hline Weg & Não & 6 & 0 & 6 & 1.00 & Não & $96.9 \%$ & $96.9 \%$ \\
\hline Wetzel & Sim & 5 & 1 & 4 & 0.60 & Não & $75.2 \%$ & $75.2 \%$ \\
\hline Wiest & Sim & 4 & 1 & 3 & 0.50 & Não & $66.1 \%$ & $66.1 \%$ \\
\hline Zivi & Sim & 3 & 2 & 1 & -0.33 & Não & $65.0 \%$ & $65.0 \%$ \\
\hline
\end{tabular}

Onde:

DE é PC? - caso diretor executivo ocupe o cargo de presidente do conselho: sim; do contrário: não;

TOT - número de membros do Conselho de Administração (tamanho do conselho);

INT - número de executivos no Conselho de Administração;

EXT - número de não executivos no Conselho de Administração;

INDEP - grau de independência do Conselho de Administração, dado pela equação:

$$
I N D E P=\left(\frac{E X T}{T O T}\right)-\left(\frac{I N T}{T O T}\right)
$$

Acordo de Acionistas? (AA) - caso a empresa possua acordo de acionistas: sim; do contrário: não;

\% ACCONTR - soma do percentual de ações ordinárias do(s) acionista(s) controlador(es) da empresa;

$\%$ ACAA - soma do percentual de ações ordinárias do(s) acionista(s) pertencente(s) ao acordo de acionistas. Caso a empresa não possua acordo de acionistas, é igual ao percentual de ações ordinárias do(s) controlador(es).

Para a coleta dos dados relativos à composição do Conselho de Administração, utilizou-se o critério definido pela CVM para classificação dos conselheiros pelas empresas. Sob este critério, as empresas classificam os conselheiros como tipo 2 caso não executem funções executivas (conselheiros externos) e como tipo 3 caso sejam conselheiros e executivos da companhia (conselheiros internos). 
A análise dos dados coletados é feita no capítulo 4, com a construção de tabelas resumindo as informações sobre as variáveis de governança e estrutura de propriedade utilizadas na pesquisa.

O sistema de informações Economática foi a fonte dos dados para o cálculo das variáveis dependentes de valor Q de Tobin (Q) e Valor da empresa sobre o ativo total (FIRMVSAT). Conforme exposto na seção 3.2.3, o Q de Tobin foi calculado pela equação simplificada de Chung e Pruitt (1994, p.71):

$$
\mathrm{Q} \text { de Tobin }=\frac{V M A O+V M A P+D I V T}{A T}
$$

Onde:

VMAO - valor de mercado das ações ordinárias;

VMAP - valor de mercado das ações preferenciais;

DIVT - valor contábil das dívidas de curto prazo somado ao valor contábil das dívidas de longo prazo menos o ativo circulante;

AT - ativo total da companhia.

Conforme a seção 3.2.3, a variável valor da empresa sobre o ativo total foi calculada pela seguinte equação:

$$
\text { FIRMVSAT }=\frac{\text { FirmValue }}{A T}
$$

Onde:

AT - ativo total da empresa;

Firm Value - indicador calculado pelo sistema de informações Economática Ltda pela fórmula:

Firm Value $=$ Cotação*Total de Ações + Debêntures CP e LP + Financiamentos CP e LP + Adiantamentos Contratos de Câmbio - Disponibilidades e Investimentos de Curto Prazo.

As variáveis de valor foram estruturadas em planilhas eletrônicas distintas para cada ano analisado. Como exemplo, segue abaixo a planilha com as variáveis de valor calculadas para o ano de 1998: 
Quadro 8 - variáveis dependentes de valor calculadas para o ano de 1998

\begin{tabular}{|c|c|c|c|c|c|}
\hline Empresa & Q98 & FIRMVSAT & Empresa & Q98 & FIRMVSAT \\
\hline Acesita & 0.55 & 0.52 & Lojas Renner & 0.75 & 0.84 \\
\hline Acos Villares & 0.59 & 0.40 & Magnesita & 0.03 & 0.06 \\
\hline Adubos Trevo & 0.48 & 0.27 & Makro & 0.55 & 0.11 \\
\hline Albarus & 0.66 & 0.68 & Manasa & 0.58 & 0.71 \\
\hline Alpargatas & 0.23 & 0.30 & Mangels & 0.25 & 0.28 \\
\hline Ambev & 1.39 & 1.23 & Marcopolo & 0.22 & 0.40 \\
\hline Antarctica Nord & 0.84 & 0.77 & Marisol & 0.30 & 0.28 \\
\hline Aracruz & 0.62 & 0.71 & Metal Leve & 0.34 & 0.25 \\
\hline Avipal & 0.20 & 0.30 & Metisa & 0.24 & 0.27 \\
\hline Bahia Sul & 0.58 & 0.74 & Millennium & 0.40 & 0.35 \\
\hline Bardella & 0.06 & 0.06 & Minupar & 0.52 & 0.21 \\
\hline Belgo Mineira & 0.37 & 0.40 & Mont Aranha & 0.29 & 0.18 \\
\hline Bic Caloi & 1.36 & 0.69 & Multibras & 0.29 & 0.39 \\
\hline Biobras & 0.23 & 0.19 & Nitrocarbono & 0.75 & 0.87 \\
\hline Bombril & 0.43 & 0.40 & Oxiteno & 0.20 & 0.20 \\
\hline Bompreco & 0.82 & 0.71 & Pao de Acucar & 0.96 & 0.72 \\
\hline Brasil T Par & 0.44 & 0.47 & Paraibuna & 0.83 & 0.50 \\
\hline Brasil Telec & 0.58 & 0.51 & Paranapanema & 0.79 & 0.56 \\
\hline Brasilit & 0.38 & 0.30 & Paul F Luz & 0.95 & 0.72 \\
\hline Brasmotor & 0.26 & 0.35 & Perdigao & 0.50 & 0.48 \\
\hline Brazil Realt & 0.68 & 0.56 & Petrobras Distrib & 0.26 & 0.26 \\
\hline Bunge Alimentos & 0.39 & 0.35 & Petrobras & 0.76 & 0.80 \\
\hline Bunge Fertilizantes & 0.47 & 0.30 & Petroflex & 0.58 & 0.37 \\
\hline Cacique & 0.10 & -0.31 & Petroq.Uniao & 0.53 & 0.43 \\
\hline Caemi Metal & 0.42 & 0.38 & Petroquisa & 0.42 & 0.19 \\
\hline Cambuci & 0.32 & 0.36 & Pettenati & 0.22 & 0.12 \\
\hline CEB & 0.35 & 0.24 & Plascar & 0.40 & 0.41 \\
\hline Celesc & 0.46 & 0.35 & Polar & 0.53 & 0.44 \\
\hline Celpe & 0.48 & 0.52 & Polialden & 0.16 & 0.14 \\
\hline Cemat & 0.57 & 0.25 & Politeno & 0.23 & 0.29 \\
\hline Cemig & 0.63 & 0.54 & Portobello & 0.44 & 0.57 \\
\hline Cerj & 1.17 & 0.89 & Pronor & 0.55 & 0.91 \\
\hline Cesp & 0.47 & 0.32 & Randon Part & 0.32 & 0.42 \\
\hline Cia Hering & 0.40 & 0.45 & Recrusul & 0.30 & 0.45 \\
\hline Coelba & 0.74 & 0.56 & Ren Hermann & 0.49 & 0.44 \\
\hline Coelce & 0.89 & 0.61 & Rhodia-Ster & 0.83 & 0.84 \\
\hline Comgas & 1.33 & 1.20 & Ripasa & 0.34 & 0.29 \\
\hline Confab & 0.20 & 0.26 & Rossi Resid & 0.54 & 0.25 \\
\hline Copel & 0.66 & 0.54 & Sabesp & 0.59 & 0.58 \\
\hline Copene & 0.39 & 0.39 & Sadia SA & 0.41 & 0.44 \\
\hline Copesul & 0.57 & 0.52 & Saint Gobain Canal & 0.39 & 0.45 \\
\hline Coteminas & 0.78 & 0.61 & Saint-Gobain Vidros & 0.57 & 0.57 \\
\hline Cremer & 0.77 & 0.47 & Sansuy & 0.71 & 0.30 \\
\hline CTMR Celular & 0.14 & 0.16 & Santista Textil & 0.26 & 0.43 \\
\hline Dimed & 0.44 & 0.34 & Saraiva Livr & N.D. & 0.78 \\
\hline Dixie Toga & 0.48 & 0.46 & Schulz & 0.10 & 0.15 \\
\hline Docas & 0.64 & 0.40 & Serrana & 0.57 & 0.38 \\
\hline Duratex & 0.40 & 0.37 & Sibra & 1.21 & 1.22 \\
\hline EBE & 0.95 & 0.42 & Sid Nacional & 0.45 & 0.47 \\
\hline Eberle & 0.84 & 0.10 & Sid Tubarao & 0.38 & 0.34 \\
\hline
\end{tabular}




\begin{tabular}{|c|c|c|c|c|c|}
\hline Empresa & Q98 & FIRMVSAT & Empresa & Q98 & FIRMVSAT \\
\hline Electrolux & 0.40 & 0.39 & Solorrico & 0.45 & 0.59 \\
\hline Elektro & N.D. & 1.04 & Souza Cruz & 0.90 & 0.98 \\
\hline Eletrobras & 0.41 & 0.38 & Supergasbras & 0.36 & 0.28 \\
\hline Eletropaulo & 0.97 & 0.67 & Suzano & 0.39 & 0.43 \\
\hline Elevad Atlas & 1.78 & 1.51 & TAM & 1.06 & 0.96 \\
\hline EMAE & 0.13 & 0.04 & Tecel.S.Jose & 0.21 & 0.22 \\
\hline Embraer & 1.34 & 0.69 & Tectoy & 0.85 & 0.70 \\
\hline Embratel Part & 0.64 & 0.65 & Teka & 0.39 & 0.34 \\
\hline Encorpar & 0.04 & 0.06 & Telasa Celular & 0.27 & 0.20 \\
\hline Enersul & 0.73 & 0.59 & Tele Celular Sul & 0.49 & 0.59 \\
\hline EPTE & 0.21 & 0.07 & Tele Centroeste Cel & 0.47 & 0.49 \\
\hline Escelsa & 0.50 & 0.62 & Tele Leste Celular & 0.52 & 0.65 \\
\hline Estrela & 0.63 & 0.13 & Tele Nordeste Celul & 0.39 & 0.49 \\
\hline Eternit & 0.24 & 0.21 & Tele Norte Celular & 0.29 & 0.34 \\
\hline Eucatex & 0.80 & 0.97 & Tele Sudeste Celula & 0.87 & 1.06 \\
\hline F Cataguazes & 0.68 & 0.62 & Telebahia & 0.47 & 0.31 \\
\hline Ferbasa & 0.14 & 0.14 & Telebrasilia Cel & 0.37 & 0.38 \\
\hline Ferro Ligas & 1.35 & 1.13 & Teleceara Celular & 0.84 & 0.83 \\
\hline Fertibras & 0.38 & 0.49 & Telegoias Celular & 0.34 & 0.42 \\
\hline Fertiza & 0.42 & 0.22 & Telemar & 0.35 & 0.37 \\
\hline Forjas Taurus & 0.06 & 0.17 & Telemig Celul Part & 0.59 & 0.49 \\
\hline Fosfertil & 0.82 & 0.69 & Telemig Celular & 1.27 & 0.88 \\
\hline Fras-Le & 0.98 & 0.88 & Telemig & 0.83 & 0.82 \\
\hline Gerasul & 0.61 & 0.49 & Telepar Celular & 0.72 & 0.70 \\
\hline Gerdau Met & 0.32 & 0.33 & Telepisa Celular & 0.03 & 0.00 \\
\hline Gerdau & 0.43 & 0.41 & Telerj & 0.71 & 0.76 \\
\hline Globex & 0.33 & 0.53 & Telern Celular & 0.27 & 0.31 \\
\hline Globo Cabo & 1.11 & 0.65 & Telesc Celular & 0.64 & 0.56 \\
\hline Gradiente & 0.53 & 0.27 & Telesp Cel Part & 1.07 & 1.11 \\
\hline Grazziotin & 0.07 & 0.17 & Telesp Operac & 0.91 & 0.94 \\
\hline Guararapes & 0.16 & 0.23 & Telma Celular & 0.04 & 0.05 \\
\hline Ind Villares & 0.63 & 0.59 & Telpa Celular & 0.33 & 0.49 \\
\hline Inds Romi & 0.22 & 0.25 & Telpe Celular & 0.98 & 1.05 \\
\hline Inepar Energia & 0.96 & 1.10 & Tex Renaux & 0.32 & 0.19 \\
\hline Inepar & 0.52 & 0.42 & Trafo & 0.29 & 0.26 \\
\hline Iochp-Maxion & 0.64 & 0.50 & Transbrasil & 0.28 & 0.28 \\
\hline Ipiranga Dist & 0.26 & 0.28 & Trevisa & 0.41 & 0.19 \\
\hline Ipiranga Pet & 0.42 & 0.43 & Trikem & 0.51 & 0.51 \\
\hline Ipiranga Ref & 0.46 & 0.58 & Tupy & 0.74 & 0.53 \\
\hline Itautec & 0.31 & 0.38 & Unipar & 0.32 & 0.37 \\
\hline Iven & 0.48 & 0.52 & Usiminas & N.D. & 0.44 \\
\hline J B Duarte & 0.94 & 0.80 & Usin C Pinto & 0.52 & 0.16 \\
\hline Karsten & 0.14 & 0.19 & Vale Rio Doce & 0.64 & 0.67 \\
\hline Kepler Weber & 0.36 & 0.36 & Variq & 0.69 & 0.69 \\
\hline Klabin & 0.44 & 0.47 & Vigor & 0.25 & 0.07 \\
\hline Kuala & 0.47 & 0.34 & Votorantim C P & 0.33 & 0.32 \\
\hline Latasa & 0.47 & 0.43 & Weg & 0.69 & 0.69 \\
\hline \begin{tabular}{|l} 
Light \\
\end{tabular} & 0.79 & 0.45 & Wembley & 0.26 & 0.24 \\
\hline LightPar & 1.06 & 0.96 & Wetzel & 1.15 & 0.31 \\
\hline Loj Americanas & 0.32 & 0.24 & Wiest & 0.48 & 0.47 \\
\hline
\end{tabular}




\subsection{Limitações da Pesquisa}

A primeira limitação importante da pesquisa diz respeito ao enfoque dado exclusivamente às características do Conselho de Administração como forma de mensuração da governança corporativa nas empresas. Conforme exposto na seção 1.1, existem outros mecanismos internos importantes para reduzir o problema de agência dos gestores e aprimorar a governança das empresas, como a remuneração dos gestores e a posse de ações pelos executivos e conselheiros. Além disso, mecanismos externos importantes descritos por Jensen (1993), como a presença de um mercado de aquisição hostil e a existência de um mercado de trabalho competitivo, também não são abordados na pesquisa. Com relação ao método de investigação utilizado, importantes limitações precisam ser apontadas.

\subsubsection{Relações de causalidade entre as variáveis e endogeneidade}

O pesquisador define ao seu juízo as relações de causalidade entre as variáveis, que não podem ser consideradas corretas de antemão. Para o presente estudo, parte-se da hipótese de que a estrutura de governança corporativa, representada pela composição e tamanho do Conselho de Administração, afeta o desempenho corporativo e o valor da empresa. Desta forma, a relação de causalidade estabelecida entre as variáveis independentes de governança corporativa e as variáveis dependentes de valor da firma e desempenho, apesar de defensável do ponto de vista teórico, pode não ser a relação correta. O problema da endogeneidade, abordado na seção 2.6.4, pode afetar de forma significativa a relação entre as variáveis, haja vista que, da mesma forma que a governança corporativa pode ser causa do desempenho corporativo e valor da firma, ela também pode ser consequiência, já que as empresas podem alterar sua estrutura de governança corporativa a partir de um determinado desempenho. Portanto, o problema da relação endógena entre as variáveis constitui uma séria limitação do presente estudo. Uma possível tentativa de correção do problema da endogeneidade é a realização de testes com período de tempo defasados, nos quais busca-se relacionar a estrutura de governança das companhias em um determinado instante com o desempenho corporativo num instante anterior ou subsequente. 


\subsubsection{Definições operacionais da pesquisa}

As definições operacionais das variáveis do modelo são questionáveis. Diversas definições alternativas podem ser propostas, servindo como aproximações justificadas para o que a pesquisa pretende medir. É difícil, entretanto, determinar objetivamente qual o nível de adequação da definição operacional adotada. Uma forma de diminuir este problema é testar a consistência do modelo a diferentes definições para as mesmas variáveis, o que é realizado no presente estudo pela utilização de mais de uma definição operacional para valor e desempenho da empresa.

Um exemplo de definição operacional problemática é a variável "independência do Conselho de Administração" que constitui uma limitação crítica do presente estudo. A literatura acadêmica e de mercado sobre Conselho de Administração afirma que um fator muito importante na determinação da efetividade do Conselho de Administração é a sua independência em relação ao diretor executivo. Entretanto, é difícil avaliar de forma quantitativa a independência do conselho nas empresas, devido às interações entre os diversos agentes da companhia (acionistas, membros do conselho e executivos), que são dinâmicas ao longo do tempo.

Uma aproximação, utilizada em quase todos os testes empíricos, é medir a independência do conselho pela composição do órgão, classificando os conselheiros em internos (executivos da companhia), externos (não executivos da companhia mas com alguma relação com a empresa) e independentes (conselheiros profissionais não executivos da companhia). Sob esta ótica, quanto maior a proporção de membros independentes no conselho, maior a independência do órgão. Apesar da dificuldade de avaliar efetivamente quando um conselheiro é independente ou alinhado aos interesses dos gestores (como exemplo, um conselheiro profissional considerado independente pode ter laços com o diretor executivo da companhia), a aproximação da independência do conselho a partir da sua composição é considerada válida e utilizada na grande maioria dos testes empíricos.

Para o presente trabalho, somente foi possível classificar os conselheiros entre internos (executivos da companhia) e externos (não executivos da companhia), pois a CVM apenas exige das empresas que classifiquem seus conselheiros em uma das duas 
opções. Portanto, a variável de governança corporativa relacionada à independência do Conselho de Administração é extremamente simplificadas, já que a divisão dos conselheiros entre executivos e não executivos dificulta a identificação da independência dos conselheiros em relação aos acionistas controladores. Dada a limitação da informação pública disponível para as empresas, utilizourse a proporção de não executivos no conselho como aproximação da independência do conselho. A impossibilidade de identificação dos conselheiros profissionais (estes os com maior probabilidade de terem uma atitude independente), faz com que conselhos com alto percentual de membros externos, considerados independentes no estudo pelo indicador utilizado, possam ser totalmente passivos e alinhados ao principal executivo da companhia, haja vista que todos podem ter sido nomeados pelo acionista controlador por laços familiares ou de amizade. Apesar da fragilidade da definição operacional escolhida, esta ainda assim pode ser considerada válida, já que a mesma definição foi utilizada em outras pesquisas e é razoável argumentar que um conselho com maioria de membros externos possui maior probabilidade de supervisionar e divergir das opiniões dos executivos do que um conselho composto pelos próprios executivos.

Resumindo, conselheiros não executivos, como parentes do acionista controlador ou antigos executivos da empresa, podem apresentar conflito de interesse com relação aos acionistas minoritários, caracterizando-os como conselheiros não executivos porém não independentes. $\mathrm{O}$ ideal seria a divisão dos conselheiros em três classificações: executivos, independentes e externos. Isto diferenciaria, dentre os conselheiros não executivos, os conselheiros profissionais (sem conflitos de interesse com qualquer um dos acionistas) dos conselheiros que não são executivos mas representam os interesses de um grupo de acionistas ou executivos da empresa.

\subsubsection{Especificação do modelo}

A especificação do modelo, ou seja, a escolha das variáveis independentes para a regressão múltipla, influencia os resultados obtidos. As variáveis de controle são importantes para uma melhor especificação do modelo, pois sua omissão pode levar a inferências equivocadas. No estudo, apesar da utilização de algumas variáveis de controle para melhorar a qualidade estatística do modelo, outras variáveis de controle 
potencialmente importantes que podem afetar a governança corporativa não foram incluídas, notadamente o percentual de ações em posse dos conselheiros e dos executivos da companhia. Segundo Bhagat e Black (1999, p.945), empresas com executivos que são acionistas significativos tendem a ter conselhos menores e menos conselheiros independentes no conselho, já que esses executivos tendem a indicar pessoas de sua confiança para representar seus interesses no conselho. A possível correlação entre a concentração da propriedade por parte de executivos e desempenho corporativo implica que as pesquisas sobre a relação entre independência do conselho e desempenho devam ter o percentual de ações dos executivos como variáveis de controle. Esta importante variável não pôde ser coletada, devido à ausência da necessidade de divulgação pública dos acionistas com menos de $5 \%$ das ações por parte das empresas e da não obrigatoriedade de divulgação das ações em posse dos executivos das companhias.

\subsubsection{Erros nos Dados}

Por fim, a qualidade de alguns dados disponíveis, principalmente informações contábeis, pode ser colocada sob suspeita. Um argumento em favor da veracidade das informações contábeis seria o fato de, por serem companhias abertas, estas empresas são fiscalizadas pelos órgãos reguladores e mercado. Entretanto, os problemas ocorridos durante o ano de 2002 no mercado norte-americano ${ }^{15}$, considerado o mais sofisticado do mundo, aumentaram a percepção de que as informações contábeis talvez não reflitam fidedignamente os números das empresas. Desta forma, erros de medida, critérios contábeis pouco claros e manipulação dos números da companhia podem gerar estimativas distorcidas dos resultados obtidos pelo modelo da pesquisa.

\footnotetext{
${ }^{15}$ Durante o ano de 2002, suspeita-se que grandes empresas americanas (Enron, WorldCom, Xerox, Merck, etc.) manipularam suas informações contábeis de forma a melhorar seus resultados financeiros artificialmente, causando uma crise de confiança em todo os mercados de capitais do mundo.
} 
3.5. Modelo da Pesquisa

3.5.1. Modelo geral da pesquisa

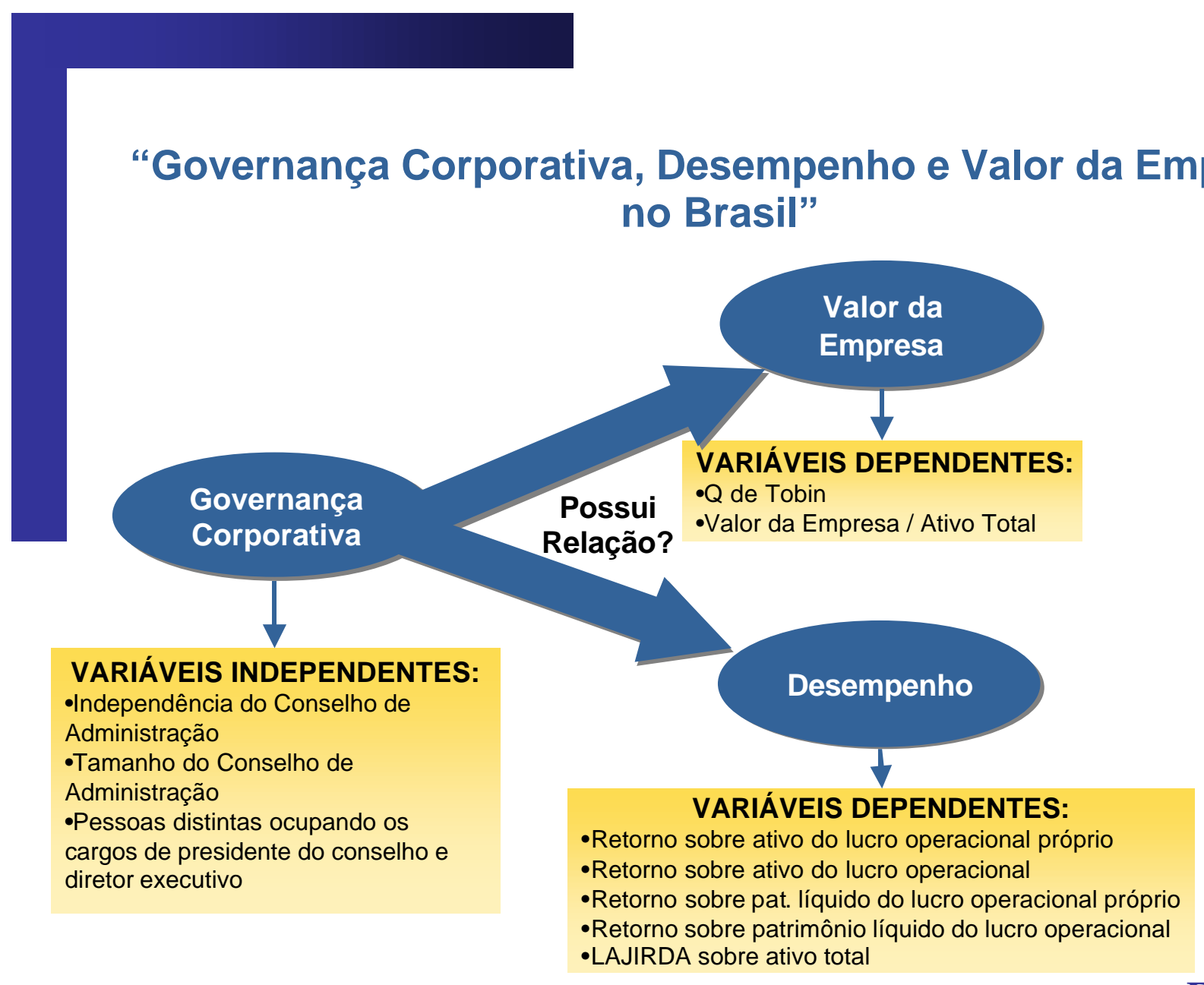

FEA-USP 


\subsubsection{Modelo Esquemático do Teste de Hipóteses}

\section{$+2$ \\ “Governança Corporativa, Desempenho e Valor da Empresa no Brasil"”}

A governança corporativa de uma empresa aberta no Brasil influencia seu valor de mercado ou desempenho?

Regressão múltipla:

\section{Teste Empírico}

1 - valor da empresa contra variáveis de governança

2 - desempenho da empresa contra variáveis de governança

Resultado: Não há relação significativa entre as variáveis Conclusão: rejeita as hipóteses alternativas de que a governança corporativa é relevante para o valor e desempenho das empresas $\left(h_{1}\right.$ e $\left.h_{2}\right)$

\section{teste de}

hipóteses

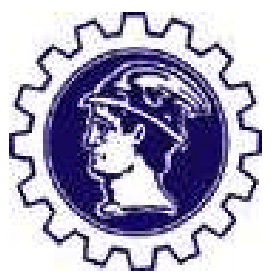

Conclusão: a governança corporativa possivelmente é relevante e as recomendações do IBGC e CVM se mostraram adequadas $\left(\mathrm{h}_{1}\right)$
Resultado: Há relação significativa entre as variáveis

Conclusão: não rejeita a hipótese de que a governança corporativa é relevante para as empresas $\left(h_{1}\right.$ e $\left.h_{2}\right)$

\section{FEA-USP}

Verifica se, em média, as empresas com melhor estrutura de governança corporativa (que seguem as recomendações do IBGC e CVM, conforme seção 3.2.2) obtiveram maior valor de mercado ou melhor desempenho

\begin{tabular}{|c|c|}
\hline \begin{tabular}{l}
\multicolumn{1}{c}{ Sim } \\
Conclusão: a governança \\
corporativa possivelmente é \\
relevante e as recomendações do \\
IBGC e CVM se mostraram \\
adequadas $\left(h_{1}\right)$
\end{tabular} & \begin{tabular}{l}
\multicolumn{1}{c}{ Não } \\
Conclusão: a governança \\
corporativa possivelmente é \\
relevante mas as recomendações \\
do IBGC e CVM não se \\
mostraram adequadas $\left(\mathrm{h}_{2}\right)$
\end{tabular} \\
\hline
\end{tabular}




\section{Análise de Resultados}

\subsection{Estrutura de Governança das Companhias Abertas Brasileiras}

Os dados relativos às variáveis de governança foram resumidos com o objetivo de identificar o perfil da estrutura de governança corporativa das companhias abertas brasileiras:

Quadro 9 - composição do Conselho de Administração das empresas em 1998

\begin{tabular}{|c|c|c|c|c|c|c|c|c|}
\hline \multirow[b]{2}{*}{ Categoria } & \multirow[b]{2}{*}{ Mediana } & \multirow{2}{*}{$\begin{array}{l}\text { Média } \\
\text { (Desvio) }\end{array}$} & \multirow[b]{2}{*}{ Mín. } & \multicolumn{4}{|c|}{ Percentis } & \multirow[b]{2}{*}{ Máx. } \\
\hline & & & & 10 & 30 & 70 & 90 & \\
\hline Conselheiros Internos & 1 & $1,1(0,9)$ & 0 & 0 & 1 & 1 & 2 & 5 \\
\hline Conselheiros Externos & 5 & $5,6(2,86)$ & 2 & 3 & 4 & 7 & 9 & 16 \\
\hline Tamanho do Conselho & 6 & $6,7(2,9)$ & 3 & 3 & 5 & 8 & 11 & 17 \\
\hline Percentual Internos & $18,2 \%$ & $17,6 \%(0,13)$ & $0 \%$ & $0 \%$ & $11 \%$ & $25 \%$ & $33 \%$ & $50 \%$ \\
\hline Percentual Externos & $81,8 \%$ & $82,4 \%(0,13)$ & $50 \%$ & $66 \%$ & $75 \%$ & $89 \%$ & $100 \%$ & $100 \%$ \\
\hline INDEP & 0,64 & $0,65(0,26)$ & 0 & 0,33 & 0,50 & 0,78 & 1,00 & 1,00 \\
\hline
\end{tabular}

Quadro 10 - composição do Conselho de Administração das empresas em 1999

\begin{tabular}{|c|c|c|c|c|c|c|c|c|}
\hline \multirow[b]{2}{*}{ Categoria } & \multirow[b]{2}{*}{ Mediana } & \multirow{2}{*}{$\begin{array}{c}\text { Média } \\
\text { (Desvio) }\end{array}$} & \multirow[b]{2}{*}{ Mín. } & \multicolumn{4}{|c|}{ Percentis } & \multirow[b]{2}{*}{ Máx. } \\
\hline & & & & $\mathbf{1 0}$ & 30 & 70 & 90 & \\
\hline Conselheiros Internos & 1 & $1,1(0,88)$ & 0 & 0 & 1 & 1 & 2 & 5 \\
\hline Conselheiros Externos & 5 & $5,6(2,94)$ & 1 & 2 & 4 & 6 & 10 & 16 \\
\hline Tamanho do Conselho & 6 & $6,7(2,93)$ & 3 & 3 & 5 & 8 & 11 & 16 \\
\hline Percentual Internos & $20,0 \%$ & $18,3 \%(0,13)$ & $0 \%$ & $0 \%$ & $11 \%$ & $25 \%$ & $33 \%$ & $67 \%$ \\
\hline Percentual Externos & $80,0 \%$ & $81,7 \%(0,13)$ & $33 \%$ & $67 \%$ & $75 \%$ & $89 \%$ & $100 \%$ & $100 \%$ \\
\hline INDEP & 0,60 & $0,63(0,27)$ & $-0,3$ & 0,33 & 0,50 & 0,78 & 1,00 & 1,00 \\
\hline
\end{tabular}

Quadro 11 - composição do Conselho de Administração das empresas em 2000

\begin{tabular}{|l|c|c|c|c|c|c|c|c|}
\hline & & Média & & \multicolumn{4}{|c|}{ Percentis } & 90 \\
Categoria & Mediana & Des vio) & Mín. & 10 & $\mathbf{3 0}$ & $\mathbf{7 0}$ & $\mathbf{9 0}$ \\
\hline Conselheiros Internos & 1 & $1,0(0,90)$ & 0 & 0 & 1 & 1 & 2 & 5 \\
Conselheiros Externos & 5 & $5,7(2,96)$ & 0 & 2 & 4 & 7 & 10 & 10 \\
Tamanho do Conselho & 6 & $6,7(3,04)$ & 3 & 3 & 5 & 8 & 11 & 19 \\
\hline Percentual Internos & $16,7 \%$ & $17,0 \%(0,15)$ & $0 \%$ & $0 \%$ & $9 \%$ & $25 \%$ & $33 \%$ & $0 \%$ \\
Percentual Externos & $83,3 \%$ & $83,0 \%(0,15)$ & $100 \%$ & $67 \%$ & $75 \%$ & $91 \%$ & $100 \%$ & $100 \%$ \\
INDEP & 0,67 & $0,66(0,30)$ & $-1,00$ & 0,33 & 0,50 & 0,82 & 1,00 & 1,00 \\
\hline
\end{tabular}


Segundo as informações acima, o conselho médio da companhia aberta brasileira é composto em sua grande maioria por conselheiros externos, que não desempenham atividades executivas na companhia. Em 1998, em média, 82,4\% dos conselheiros das companhias abertas brasileiras eram externos. Este percentual caiu para $81,7 \%$ em 1999, voltando a subir para 83,0\% em 2000. Como consequiência direta das informações, o problema da existência de um Conselho de Administração dominado pelos internos (executivos da companhia) nas decisões do órgão, tema muito abordado nos trabalhos sobre o sistema anglo-saxão de governança, praticamente não ocorre nas companhias abertas brasileiras.

A primeira vista, a alta proporção de conselheiros externos nas companhias abertas brasileiras pode ser interpretada como uma adequação das companhias ao que é recomendado pelos principais códigos de governança, isto é, à separação das funções do conselho e da diretoria pela presença de pessoas distintas nos respectivos órgãos. Da mesma forma, a alta proporção de conselheiros externos conduz à percepção inicial de que os conselhos das empresas brasileiras podem ser considerados muito independentes. Entretanto, a aparente independência dos conselhos das companhias abertas brasileiras deve ser questionada por alguns fatores.

Em primeiro lugar, o alto índice de externos era esperado, haja vista que a Lei das Sociedades por Ações (Lei no 6.404, de 15 de dezembro de 1976) define que no máximo um terço do conselho pode ser composto por diretores da companhia (parágrafo $1^{\mathrm{o}}$ do artigo 143$)^{16}$. Desta forma, já existe uma determinação legal de que os conselhos brasileiros devam ser compostos com maioria de membros externos. Aplicando o limite legal máximo de um terço de internos na fórmula utilizada para cálculo da independência do conselho (INDEP), era de se esperar que todas as empresas apresentassem um INDEP mínimo de 0,33. Entretanto, 5,5\% das empresas em 1998 apresentaram INDEP menor que 0,33, caracterizando-as como empresas em situação irregular, por apresentarem maior proporção de diretores no Conselho de Administração do que o permitido pela lei. Este percentual de empresas irregulares diminuiu para 4,0\% em 1999 e para 3,6\% em 2000.

\footnotetext{
${ }^{16}$ Segundo o texto original da Lei, "Os membros do conselho de administração, até o máximo de um terço, poderão ser eleitos para cargos de diretores".
} 
Outro fator importante é que a alta proporção de conselheiros externos não significa necessariamente uma maior independência do conselho. Nos conselhos das companhias abertas brasileiras, a maioria dos membros externos é composta por conselheiros indicados pelo acionista controlador para representar seus interesses, e não por conselheiros profissionais sem vínculos com a companhia. Esta situação ocorre como conseqüência da forte concentração das ações com direito a voto, apresentada nos quadros 14,15 e 16 , que faz com que o acionista controlador tenha poder para indicar a maioria dos conselheiros e, portanto, decidir sobre as questões corporativas mais importantes. Como a definição operacional de independência do conselho utilizada na pesquisa leva em conta apenas os conselheiros externos e internos, a existência de conselheiros externos porém não independentes constitui uma séria limitação do estudo, conforme descrito na seção 3.3 .

Com relação ao tamanho do Conselho de Administração, em média, os conselhos das companhias abertas brasileiras têm 6,7 membros. Este tamanho é adequado ao recomendado pelos códigos de governança do IBGC e da CVM, que sugerem que o conselho deva ter de cinco a nove membros.

Um aspecto importante a ser lembrado é que a Lei das Sociedades por Ações (Lei no 6.404, de 15 de dezembro de 1976) define que os conselhos devam ser compostos por, no mínimo, três membros (artigo 140). Desta forma, é razoável supor que as empresas que adotam um conselho com apenas três membros o fazem em grande parte para o simples atendimento da lei. Além disso, estes conselhos possuem menor probabilidade de atuação efetiva, haja vista a dificuldade de um grupo formado por apenas três pessoas cumprir todos os papéis atribuídos ao conselho de uma grande empresa. Somando esta dificuldade de se ter um conselho eficiente com apenas três pessoas às recomendações dos principais códigos e ao aumento da discussão em torno da governança corporativa nos últimos anos, era de esperar que a proporção de empresas com apenas três membros no conselho diminuísse ao longo do tempo. Surpreendentemente, entretanto, este percentual subiu de $12 \%$ em 1998 para $14 \%$ em 1999 e para $14,4 \%$ em 2000.

A análise da evolução da composição e tamanho dos conselhos mostra que os números permanecem praticamente constantes ao longo dos anos, não apresentando 
uma tendência clara de aumento ou diminuição da proporção de conselheiros externos ou tamanho do conselho. Isto se deve em grande parte ao fato das empresas componentes das amostras de cada ano terem sido quase as mesmas (devido ao fato de ter havido pouca mobilidade entre as empresas que apresentaram maior liquidez na Bovespa e na SOMA) e alterarem pouco a composição e tamanho dos seus Conselhos de Administração.

Outra informação importante sobre a governança nas empresas brasileiras, apresentada no quadro 12, é relacionada à separação dos cargos de diretor executivo e presidente do conselho. Os estudos acadêmicos e códigos de governança recomendam que os cargos sejam ocupados por pessoas distintas, de forma a evitar que o principal executivo detenha um poder excessivo, se "entrincheirando" na posição.

Quadro 12 - percentual de empresas com a mesma pessoa ocupando os cargos de diretor executivo e presidente do conselho

\begin{tabular}{|l|c|c|c|}
\hline Ano & 1998 & 1999 & 2000 \\
\hline $\begin{array}{l}\text { Percentual de empresas com cargos unificados de } \\
\text { diretor executivo e presidente do conselho }\end{array}$ & $\mathbf{4 1 , 5 \%}$ & $\mathbf{4 1 , 5 \%}$ & $\mathbf{3 7 , 1 \%}$ \\
\hline
\end{tabular}

As informações do quadro acima permitem constatar que em cerca de $40 \%$ das companhias abertas brasileiras os cargos de diretor executivo e presidente do conselho são ocupados pela mesma pessoa. Levando em conta as informações dos quadros 9, $10 \mathrm{e}$ 11 de que, em média, apenas 17,6\% dos conselheiros são executivos das empresas, esta se torna uma informação importante, pois sugere que o diretor executivo consegue eleger-se presidente do conselho graças à sua posição como acionista controlador, e não à sua posição como diretor executivo. Desta forma, a variável apresentada no quadro 12 se mostra mais apropriada para diferenciar as empresas em termos de concentração de poder do que a proporção de externos no conselho, deixando claro em quais empresas o acionista controlador possui posição ativa como principal executivo da companhia. Com relação à evolução deste indicador, nota-se uma pequena diminuição do percentual de empresas com unificação dos cargos de diretor executivo e presidente do conselho, na direção das recomendações acadêmicas e de mercado.

O acordo de acionistas representa um consenso dos acionistas controladores sobre a forma pela qual algumas questões corporativas importantes devem ser 
resolvidas. Sua presença pode aumentar o potencial de expropriação dos acionistas minoritários, já que exclui a possibilidade de sua interferência nos temas definidos no acordo. São apresentadas no quadro 13 as informações referentes à presença do acordo de acionistas nas companhias abertas brasileiras.

Quadro 13 - percentual de empresas com presença de acordo de acionistas

\begin{tabular}{|r|c|c|c|}
\hline Ano & 1998 & 1999 & 2000 \\
\hline Percentual de empresas com acordo de acionistas & $\mathbf{2 2 , 0 \%}$ & $\mathbf{2 4 , 0 \%}$ & $\mathbf{2 3 , 7 \%}$ \\
\hline
\end{tabular}

Segundo as informações acima, em média, 23\% das empresas brasileiras possuem acordo de acionistas, um percentual significativo que não apresenta qualquer tendência clara de evolução.

As variáveis relacionadas à estrutura de propriedade são importantes nas pesquisas sobre governança corporativa. No presente estudo, duas foram calculadas para utilização como variáveis de controle no modelo de forma a melhorar a qualidade estatística dos resultados. O percentual de ações dos acionistas controladores foi calculado pela soma do percentual das ações ordinárias dos acionistas identificados pelas empresas como controladores nos relatórios anuais para a CVM. Da mesma forma, o percentual de ações dos acionistas participantes do acordo de acionistas foi calculado pela soma da ações ordinárias dos acionistas identificados pelas empresas como participantes do acordo de acionista. Conforme apresentado na seção 3.3, o cálculo de outras variáveis de controle relacionadas à estrutura de propriedade (como o percentual de ações em posse dos executivos e dos conselheiros da empresa) seria importante para o aprimoramento do modelo da pesquisa. Entretanto, as empresas não são obrigadas a divulgar estas informações, impossibilitando a coleta dos dados. 
Quadro 14- estrutura de propriedade das empresas em 1998

\begin{tabular}{|c|c|c|c|c|c|c|c|c|}
\hline & & Média & & \multicolumn{4}{|c|}{ Percentis } & \\
\cline { 5 - 7 } & Mediana & (Desvio) & Mín. & $\mathbf{1 0}$ & $\mathbf{3 0}$ & $\mathbf{7 0}$ & $\mathbf{9 0}$ & Máx. \\
\hline $\begin{array}{c}\text { \% Ações acionistas } \\
\text { controladores }\end{array}$ & $75,8 \%$ & $73,8 \%(0,2)$ & $23 \%$ & $50 \%$ & $60 \%$ & $89 \%$ & $99 \%$ & $100 \%$ \\
$\begin{array}{c}\text { \% Ações participantes } \\
\text { acordo de acionistas }\end{array}$ & $77,4 \%$ & $75,0 \%(0,2)$ & $23 \%$ & $50 \%$ & $65 \%$ & $90 \%$ & $100 \%$ & $100 \%$ \\
\hline
\end{tabular}

Quadro 15 - estrutura de propriedade das empresas em 1999

\begin{tabular}{|c|c|c|c|c|c|c|c|c|}
\hline \multirow[b]{2}{*}{ Categoria } & \multirow[b]{2}{*}{ Mediana } & \multirow{2}{*}{$\begin{array}{c}\text { Média } \\
\text { (Desvio) }\end{array}$} & \multirow[b]{2}{*}{ Mín. } & \multicolumn{4}{|c|}{ Percentis } & \multirow[b]{2}{*}{ Máx. } \\
\hline & & & & 10 & 30 & 70 & 90 & \\
\hline $\begin{array}{c}\% \text { Ações acionistas } \\
\text { controladores }\end{array}$ & $77,3 \%$ & $74,5 \%(0,2)$ & $23 \%$ & $50 \%$ & $60 \%$ & $89 \%$ & $99 \%$ & $100 \%$ \\
\hline $\begin{array}{l}\text { \% Ações participantes } \\
\text { acordo de acionistas }\end{array}$ & $80,7 \%$ & $76,2 \%(0,2)$ & $23 \%$ & $50 \%$ & $65 \%$ & $91 \%$ & $100 \%$ & $100 \%$ \\
\hline
\end{tabular}

Quadro 16 - estrutura de propriedade das empresas em 2000

\begin{tabular}{|c|c|c|c|c|c|c|c|c|}
\hline \multirow[b]{2}{*}{ Categoria } & \multirow[b]{2}{*}{ Mediana } & \multirow{2}{*}{$\begin{array}{c}\text { Média } \\
\text { (Desvio) }\end{array}$} & \multirow[b]{2}{*}{ Mín. } & \multicolumn{4}{|c|}{ Percentis } & \multirow[b]{2}{*}{ Máx. } \\
\hline & & & & 10 & 30 & 70 & 90 & \\
\hline $\begin{array}{l}\text { \% Ações acionistas } \\
\text { controladores }\end{array}$ & $77,4 \%$ & $75,6 \%(0,19)$ & $23 \%$ & $51 \%$ & $64 \%$ & $90 \%$ & $99 \%$ & $100 \%$ \\
\hline $\begin{array}{l}\text { \% Ações participantes } \\
\text { acordo de acionistas }\end{array}$ & $81,0 \%$ & $77,1 \%(0,19)$ & $23 \%$ & $51 \%$ & $66 \%$ & $92 \%$ & $100 \%$ & $100 \%$ \\
\hline
\end{tabular}

Os quadros 14, 15 e 16 mostram uma forte concentração da propriedade nas companhias abertas brasileiras, com os acionistas controladores possuindo em média $74,6 \%$ das ações com direito a voto. Poder-se-ia esperar que, em uma economia em desenvolvimento, a propriedade das empresas se tornasse mais difusa ao longo dos anos, em virtude da necessidade de captação de recursos por parte das empresas e do desenvolvimento do mercado de capitais. Entretanto, a tendência apresentada no Brasil é inversa, com um aumento na concentração das ações ordinárias em posse dos acionistas controladores de 73,8\% em 1998 para 75,6\% em 2000. Da mesma forma, o percentual de ações ordinárias em posse dos acionistas participantes do acordo de acionista também aumenta, de 75,0\% em 1998 para 77,1\% em 2000. Os valores encontrados permitem constatar que a companhia aberta brasileira possui acionistas controladores com forte poder de decisão e que esta situação não tende a ser alterada no curto prazo. Esta constatação corrobora o ceticismo de La Porta et al. (1999c, p.507) em relação à idéia bastante difundia de que o padrão da estrutura de propriedade das empresas tende a evoluir para o modelo de Berle e Means (1932) com estrutura de propriedade pulverizada e separação clara de acionistas e executivos. Segundo La Porta 
et al. (1999c, p.507), a pulverização da estrutura de propriedade teria que ocorrer como conseqüência de um aperfeiçoamento do sistema legal, que acarretasse maior proteção aos acionistas. Entretanto, nos países com fraca proteção legal, o aperfeiçoamento do sistema legal diminuiria os benefícios privados do controle dos acionistas controladores (utilização dos direitos de controle para gerar aos controladores um ganho extra além do que seria justo pela sua fatia da propriedade), acarretando na diminuição do valor de controle das empresas e na transferência de riqueza dos controladores para os minoritários. Como os acionistas controladores possuem maior poder de persuasão político nesses países e não parecem apoiar as reformas legais para uma maior proteção aos minoritários, os autores sugerem que esta situação não tende a ser alterada.

A análise dos percentis permite observar que em cerca de 30\% das companhias abertas os acionistas controladores possuem mais que $90 \%$ das ações ordinárias, conferindo-lhes poder quase que total sobre as decisões corporativas. Quando esta forte concentração de propriedade das ações ordinárias é somada à alta proporção de ações preferenciais emitidas (sem direito a voto) e à freqüente utilização de estruturas piramidais nas companhias (holdings que controlam empresas que controlam subsidiárias), tem-se uma situação na qual os controladores possuem direitos de decisão maiores que seus direitos sobre o fluxo de caixa (sua fatia sobre o capital total da companhia), acarretando numa maior probabilidade de expropriação dos demais acionistas.

\subsection{Resultados dos testes de hipóteses}

Os resultados obtidos em cada ano pesquisado foram divididos em três tópicos:

1. matriz de correlações;

2. relação entre governa nça corporativa e valor;

3. relação entre governança corporativa e desempenho.

O tópico "matriz de correlações" consiste em uma análise preliminar do sentido e magnitude das relações lineares entre as variáveis. Apesar de ser uma análise extremamente simplista e pouco conclusiva, é uma ferramenta útil, dando sensibilidade ao pesquisador sobre as relações entre as variáveis e auxiliando-o na construção do 
modelo. A análise da matriz de correlações mostrou, de maneira geral, uma correlação fraca entre as variáveis. São comentadas as correlações significativas estatisticamente, mesmo que com baixo valor absoluto.

O tópico "relação entre governança corporativa e valor" apresenta os modelos que se mostraram mais adequados aos pressupostos de um Modelo de Regressão Linear (MRL) na relação entre as variáveis de governança corporativa e valor da empresa, conforme a equação da seção 3.1:

$V_{i}=\alpha_{1}+\beta_{11} * I N D E P_{i}+\beta_{21} * \log \left(\right.$ TOT $\left._{i}\right)+\beta_{31} *\left(\log \left(\text { TOT }_{i}\right)^{2}\right)+\beta_{41} * D E_{i}+\sum_{i=1}^{k} \beta_{i 1} * V C_{i}+\varepsilon_{i 1}$

O tópico "relação entre governança corporativa e desempenho" apresenta os modelos que se mostraram mais adequados aos pressupostos de um Modelo de Regressão Linear (MRL) na relação entre as variáveis de governança corporativa e desempenho, conforme a equação da seção 3.1 :

$D_{i}=\alpha_{1}+\beta_{12} * \operatorname{INDEP}_{i}+\beta_{22} * \log \left(T_{O} T_{i}\right)+\beta_{32} *\left(\log \left(\text { TOT }_{i}\right)^{2}\right)+\beta_{42} * D E_{i}+\sum_{i=1}^{k} \beta_{i 2} * V C_{i}+\varepsilon_{i}$

Segundo Pyndick e Rubinfeld (1998, p.86), os pressupostos de um Modelo de Regressão Linear (MRL) para uma regressão múltipla são:

1 - o relacionamento entre a variável dependente e as variáveis independentes é linear e dado pela equação:

$$
Y_{i}=\beta_{1}+\beta_{2} * X_{2 i}+\beta_{3} * X_{3 i}+\ldots+\beta_{k} * X_{k i}+\varepsilon_{i}
$$

onde:

$Y$ - variável dependente;

$X^{\prime}$ s - variáveis independentes, com $X_{2 i}$ representando a i-ésima observação sobre a variável independente (explanatória) $X_{2}$;

$\beta_{l}$ - termo constante, ou intercepto, da equação;

$\varepsilon_{i}$ - termo de erro aleatório;

2 - as variáveis $X^{\prime}$ s são não estocásticas. Ademais, não existe um relacionamento linear exato entre duas ou mais variáveis independentes;

3 - o termo de erro possui valor esperado igual a zero para todas as observações: $\mathrm{E}(\boldsymbol{\varepsilon})=0$ 
4 - o termo de erro possui variância constante para todas as observações;

5 - os erros das diferentes observações são independentes e, portanto, não correlacionados;

6 - o termo de erro possui distribuição Normal.

A análise da adequação dos modelos aos pressupostos de um Modelo de Regressão Linear (MRL) foi feita pela aplicação do teste de heterocedasticidade de White, do teste da normalidade dos resíduos de Jarque-Bera e do cálculo do Número de Condição. O teste de White pode ser considerado um teste geral, já que mede a adequação do modelo à três pressupostos de um MRL (pressupostos 1, 4 e 5): a especificação linear correta das variáveis, a homocedasticidade dos termos de erro ${ }^{17}$ e a independência dos resíduos em relação aos regressores. O teste de Jarque-Bera mede a adequação do modelo com relação à distribuição Normal dos termos de erro (pressuposto 6). O cálculo do Número de Condição (NC) analisa se o modelo não apresenta problemas de multicolinearidade (pressuposto 2), que ocorre quando duas ou mais variáveis independentes são altamente correlacionadas. O pressuposto 3 , segundo Pyndick e Rubinfeld (1998, p.59), não é restritivo para a qualidade estatística do modelo, pois caso o termo de erro não tenha média igual a zero, o modelo corrigido será análogo ao modelo original, porém com um intercepto $\left(\beta_{l}\right)$ diferente. Por fím, como o teste não envolve séries temporais, a análise da autocorrelação dos termos de erro não demandou análise específica.

A seleção do melhor modelo foi feita com base nos níveis de significância estatística dos regressores (valor da probabilidade associado à estatística $t$ ), no Rquadrado ajustado e no Critério de Informação de Schwarz. O Rquadrado indica em que medida o modelo construído explica o comportamento da variável dependente. $\mathrm{O}$ Critério de Informação de Schwarz dá uma idéia da significância econômica das variáveis, priorizando variáveis que podem ter um nível de significância estatística menor mas que podem ser mais interessantes para o modelo em virtude do valor absoluto dos seus coeficientes.

${ }^{17}$ A condição de homocedasticidade significa que a variância dos termos de erro do modelo é constante. 
Foram omitidos os modelos que obtiveram adequação inferior aos pressupostos de um MRL e resultados menos importantes, haja vista o grande número de modelos testados e a limitação de espaço do trabalho. Para todos os modelos, foram analisadas as observações extremas (outliers) que mostravam valores das variáveis muito discrepantes do conjunto das empresas. Optou-se por retirar as observações extremas que prejudicavam a qualidade estatística dos modelos, mas que não comprometiam as principais conclusões. As principais conclusões se mantiveram inalteradas em todos os modelos, com e sem as observações extremas, e os modelos sem observações extremas apresentaram uma qualidade estatística bem superior. Apesar de terem sido feitas regressões das variáveis de governança de forma isolada contra variáveis dependentes (ex. DE vs Q), esses modelos não são reportados, haja vista que os resultados não se mostraram muito diferentes dos obtidos no modelo original, com todas as variáveis simultaneamente.

\subsubsection{Resultados de 2000}

\subsubsection{Matriz de Correlações em 2000}

Apesar das correlações diretas terem se mostrado fracas, o sentido do relacionamento entre as variáveis leva à algumas considerações:

Quadro 17 - correlações entre as variáveis de governança no ano de 2000

\begin{tabular}{lccl}
\hline & INDEP & TOT & \multicolumn{1}{c}{ DE } \\
\hline INDEP & 1.0000 & 0.2796 & -0.5493 \\
\hline TOT & & 1.0000 & -0.1152 \\
\hline DE & & & 1.0000 \\
\hline
\end{tabular}

As correlações acima indicam que:

1. quanto maior a independência do conselho (INDEP), menor a probabilidade dos cargos de diretor executivo e presidente do conselho (DE) serem ocupados pela mesma pessoa, corroborando a hipótese de que um conselho independente tende a indicar como seu presidente um membro que não seja o diretor executivo da companhia, de forma a proporcionar um maior equilíbrio de poder;

2. quanto maior a probabilidade dos cargos de presidente do conselho e diretor executivo (DE) serem ocupados pela mesma pessoa, menor o tamanho do conselho (TOT). Isto reforça a hipótese de que as empresas com um forte acionista 
controlador (com maior probabilidade de ocupar simultaneamente os cargos de diretor executivo e presidente do conselho) tendem a ter conselhos menores, muitas vezes com o tamanho mínimo estabelecido por lei, com propósito meramente formal.

Quadro 18 - correlações entre as variáveis de governança, estrutura de propriedade e valor no ano de 2000

\begin{tabular}{|c|c|c|c|c|c|c|c|c|}
\hline & INDEP & TOT & DE & ACCONTR & AA & ACAA & Q00 & FIRMVSAT \\
\hline INDEP & 1.0000 & 0.2749 & -0.5441 & 0.0258 & 0.2376 & 0.0291 & -0.0243 & 0.0506 \\
\hline TOT & & 1.0000 & -0.1077 & -0.2271 & 0.1666 & -0.1866 & -0.0518 & 0.0390 \\
\hline $\mathrm{DE}$ & & & 1.0000 & -0.0820 & -0.2025 & -0.1070 & -0.1246 & -0.2094 \\
\hline ACCONTR & & & & 1.0000 & -0.0858 & 0.9330 & -0.0310 & -0.0508 \\
\hline AA & & & & & 1.0000 & 0.0525 & 0.0743 & 0.1241 \\
\hline ACAA & & & & & & 1.0000 & 0.0267 & 0.0100 \\
\hline Q00 & & & & & & & 1.0000 & 0.8680 \\
\hline FIRMVSAT & & & & & & & & 1.0000 \\
\hline
\end{tabular}

As correlações do quadro 18 indicam que:

1. quanto maior a independência do conselho (INDEP), maior a probabilidade da existência de acordo de acionistas (AA). Este resultado pode sugerir que, como acordo de acionistas já define o mecanismo de resolução das decisões corporativas importantes, os acionistas participantes do acordo se sentiriam mais predispostos a indicar membros externos para o conselho (que seguirão suas orientações nas votações);

2. quanto maior a concentração de ações ordinárias pelos controladores (ACCONTR), menor o tamanho do conselho (TOT). Isto corrobora o comentário 2 do quadro 17, indicando que, quanto maior o poder do acionista controlador, menor é o tamanho do conselho que ele tende a constituir, talvez como forma de diminuir custos e evitar opiniões divergentes no órgão;

3. quanto maior a unificação dos cargos de diretor executivo e presidente do conselho (DE), menor o valor da empresa (Q e FIRMVSAT). Esta informação corrobora a hipótese da pesquisa de que a ocupação dos dois principais cargos da companhia pela mesma pessoa não é saudável para a companhia;

4. quanto maior a presença de acordo de acionistas (AA), maior o valor da empresa (FIRMVSAT). Esta é uma informação surpreendente, pois a presença de acordo de acionistas poderia ser entendida como um aumento do potencial de expropriação aos minoritários (por deixá-los de fora das decisões importantes) que poderia levar a um menor valor corporativo; 
5. quanto maior a unificação dos cargos de diretor executivo e presidente do conselho (DE), menor a presença de acordo de acionistas (AA). Isto sugere que, nas empresas onde os cargos de diretor executivo e presidente do conselho são ocupados pela mesma pessoa, o acionista controlador possui um percentual tão alto das ações ordinárias que torna dispensável a celebração de acordo de acionistas.

Quadro 19 - correlações entre as variáveis de governança, estrutura de propriedade e desempenho no ano de 2000

\begin{tabular}{|c|c|c|c|c|c|c|c|c|c|c|c|}
\hline & INDEP & TOT & DE & ACCONTR & AA & ACAA & RSAOP & RSAPR & RSPLOP & RSPLPR & EBISAT1 \\
\hline INDEP & 1.0000 & 0.2134 & -0.5428 & 30.0833 & 0.1986 & 0.0752 & 0.0723 & 0.1222 & 0.0032 & 0.0118 & 0.0275 \\
\hline TOT & & 1.0000 & -0.0830 & -0.2011 & 0.1968 & -0.1592 & 0.1176 & 0.0669 & 0.0069 & 0.0100 & -0.0834 \\
\hline $\mathrm{DE}$ & & & 1.0000 & -0.1151 & -0.1929 & -0.1345 & -0.0500 & -0.1408 & 0.0411 & -0.0559 & -0.1365 \\
\hline ACCONIR & & & & 1.0000 & -0.1086 & 0.9255 & 0.0544 & 0.0418 & 0.0647 & -0.0727 & 0.0644 \\
\hline AA & & & & & 1.0000 & 0.0420 & 0.0869 & 0.1051 & -0.1383 & 0.1485 & 0.1240 \\
\hline ACAA & & & & & & 1.0000 & 0.0145 & 0.0050 & -0.0457 & 0.0358 & 0.0651 \\
\hline RSAOP & & & & & & & 1.0000 & 0.6882 & 0.0926 & -0.0506 & 0.4102 \\
\hline RSAPR & & & & & & & & 1.0000 & 0.0352 & 0.0231 & 0.6390 \\
\hline RSPLOP & & & & & & & & & 1.0000 & -0.9897 & 0.0492 \\
\hline RSPLPR & & & & & & & & & & 1.0000 & -0.0096 \\
\hline EBITSAT1 & & & & & & & & & & & 1.0000 \\
\hline
\end{tabular}

As correlações do quadro 19 indicam que:

1. quanto maior a independência do conselho (INDEP), maior o retorno sobre o ativo com base no lucro operacional próprio (RSAPR). Esta relação corrobora a hipótese da pesquisa de que a independência do conselho é saudável para a companhia;

2. a relação entre o tamanho do conselho (TOT) e as variáveis de desempenho é ambígua, sem uma relação definida;

3. quanto maior a unificação dos cargos de diretor executivo e presidente do conselho (DE), pior o desempenho da empresa (RSAPR e EBITSAT). Esta informação corrobora a hipótese da pesquisa de que a ocupação dos dois principais cargos da companhia pela mesma pessoa não é saudável para a companhia.

\subsubsection{Relação entre governança corporativa e valor em 2000}

A variável diretor executivo como presidente do conselho (DE) foi a variável de governança com os resultados mais importantes no ano de 2000, apresentando uma correlação negativa significante estatisticamente no nível de $1 \%$ (valor da probabilidade associado à estatística $t$ ) contra as variáveis dependentes de valor $\mathrm{Q}$ de Tobin $(\mathrm{Q}) \mathrm{e}$ valor da empresa sobre o ativo total (FIRMVSAT). Em ambos os casos, os resultados indicam claramente que as empresas que tiveram pessoas distintas ocupando os cargos 
de diretor executivo e presidente do conselho obtiveram, em média, maior valor de mercado, corroborando a hipótese de que a adoção das recomendações do IBGC e CVM para separação dos cargos é saudável para as empresas. Com relação ao tamanho do conselho (TOT), foi obtida uma relação quadrática negativa no nível de significância de 10\% contra a variável FIRMVSAT, e uma ausência de relação estatística significativa contra a variável Q. Ademais, foram construídos modelos sem a utilização da escala logarítmica para a variável TOT. Os resultados foram semelhantes, com uma relação significante a $10 \%$ contra FIRMVSAT e uma ausência de relação quadrática significante contra Q. Com relação aos sinais dos coeficientes de TOT, era esperado que o sinal do coeficiente linear fosse positivo e que o sinal do coeficiente quadrático fosse negativo (indicando uma concavidade para baixo da curva), de forma a corroborar as recomendações do IBGC e CVM de que existe uma faixa ótima para o tamanho do conselho. Esse foi exatamente o resultado obtido no modelo que apresentou significância estatística (contra FIRMVSAT), com os sinais dos coeficientes de TOT indicando uma relação curvilínea negativa com uma faixa ótima para o tamanho do conselho. $\mathrm{O}$ resultado foi o mesmo na variante do modelo sem a utilização da escala logarítmica para a variável TOT. Foram construídos dois gráficos para visualizar a faixa ótima obtida para o tamanho do conselho. No modelo original do trabalho, obteve-se uma faixa ótima de cinco a seis membros, com o valor máximo de FIRMVSAT correspondendo a um conselho com 5,15 membros. Na variante do modelo, sem a escala logarítmica para TOT, obteve-se uma faixa ótima de cinco a sete membros para o tamanho do conselho, com o valor máximo de FIRMVSAT correspondendo a um conselho com 6,16 membros. Mais importante do que o número específico de conselheiros que resultou em valor máximo no período, é constatar a existência de uma relação quadrática significativa com concavidade negativa da variável TOT e a presença de uma faixa ótima para o tamanho do conselho, conforme as recomendações do IBGC e CVM. Por fim, em 2000 a variável independência do conselho (INDEP) não apresentou relação estatística significativa contra as variáveis de valor. Os resultados dos principais modelos são apresentados na sequiência. 
Quadro 20 - Relação entre a variável valor da empresa sobre ativo total (FIRMVSAT) e as variáveis de governança em 2000

\begin{tabular}{crrrr}
\hline \hline Variável & Coeficiente & \multicolumn{1}{c}{$\begin{array}{c}\text { Erro } \\
\text { Padrão }\end{array}$} & Estatística t & Prob. \\
& \multicolumn{4}{c}{ Par } \\
C & 0.129728 & 0.192304 & 0.674599 & 0.5009 \\
DE & -0.125321 & 0.031199 & -4.016879 & $\mathbf{0 . 0 0 0 1}$ \\
INDEP & -0.032955 & 0.052086 & -0.632709 & 0.5279 \\
LOG(TOT) & 0.381585 & 0.215447 & 1.771129 & $\mathbf{0 . 0 7 8 5}$ \\
LOG(TOT)^2 $^{\text {SORV }}$ & -0.116358 & 0.058388 & -1.992859 & $\mathbf{0 . 0 4 8 0}$ \\
SERT & 0.097172 & 0.029009 & 3.349673 & 0.0010 \\
DIVTSAT & 0.005077 & 0.000802 & 6.332191 & 0.0000 \\
& & & & \\
\hline \hline R-quadrado & 0.370514 & Critério de Schwarz & -0.732829 \\
R-quadrado ajustado & 0.345989 & Prob(estatística F) & 0.000000 \\
& & & & \\
\hline \hline
\end{tabular}

Equação:

$================$

FIRMVSATO0 $=0.1297279343-\mathbf{0 . 1 2 5 3 2 0 6 6 5 9} * \mathrm{DE}-0.0329551214^{*}$ INDEP +

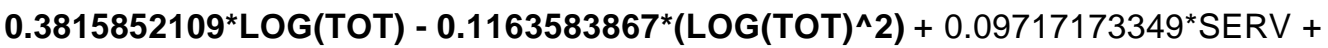
$0.005076743352^{*}$ DIVTSAT

Teste de Heterocedasticidade de White:

\begin{tabular}{lllr}
\hline \hline \# Obs * R-quadrado & 23.12244 & Probabilidade & 0.512580
\end{tabular}

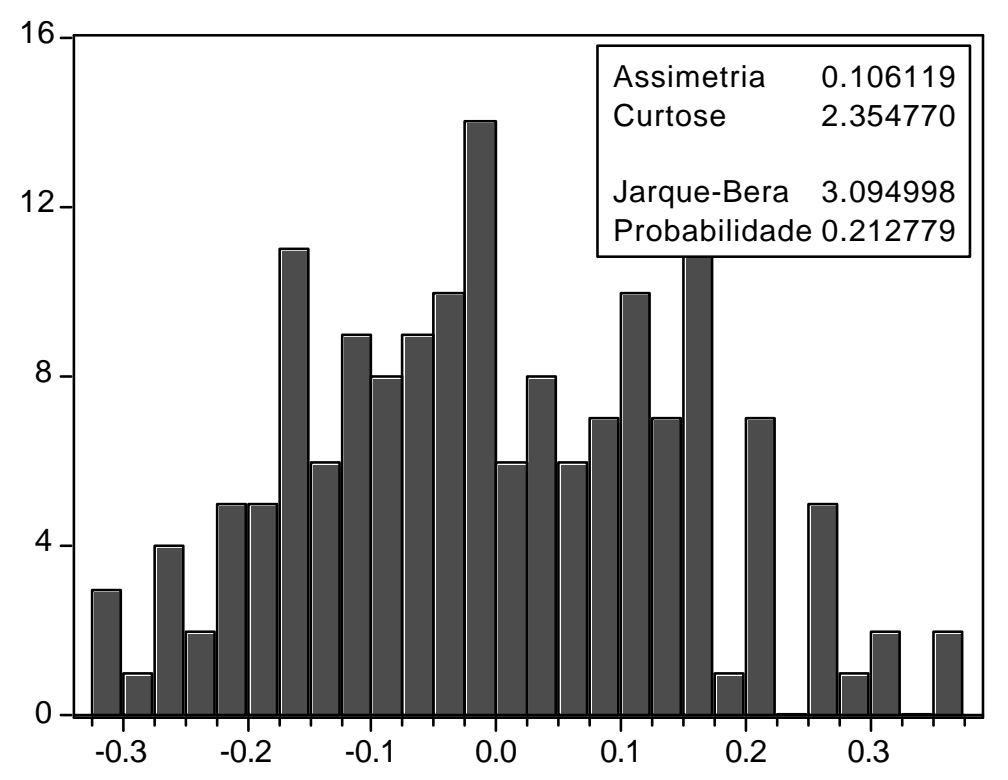




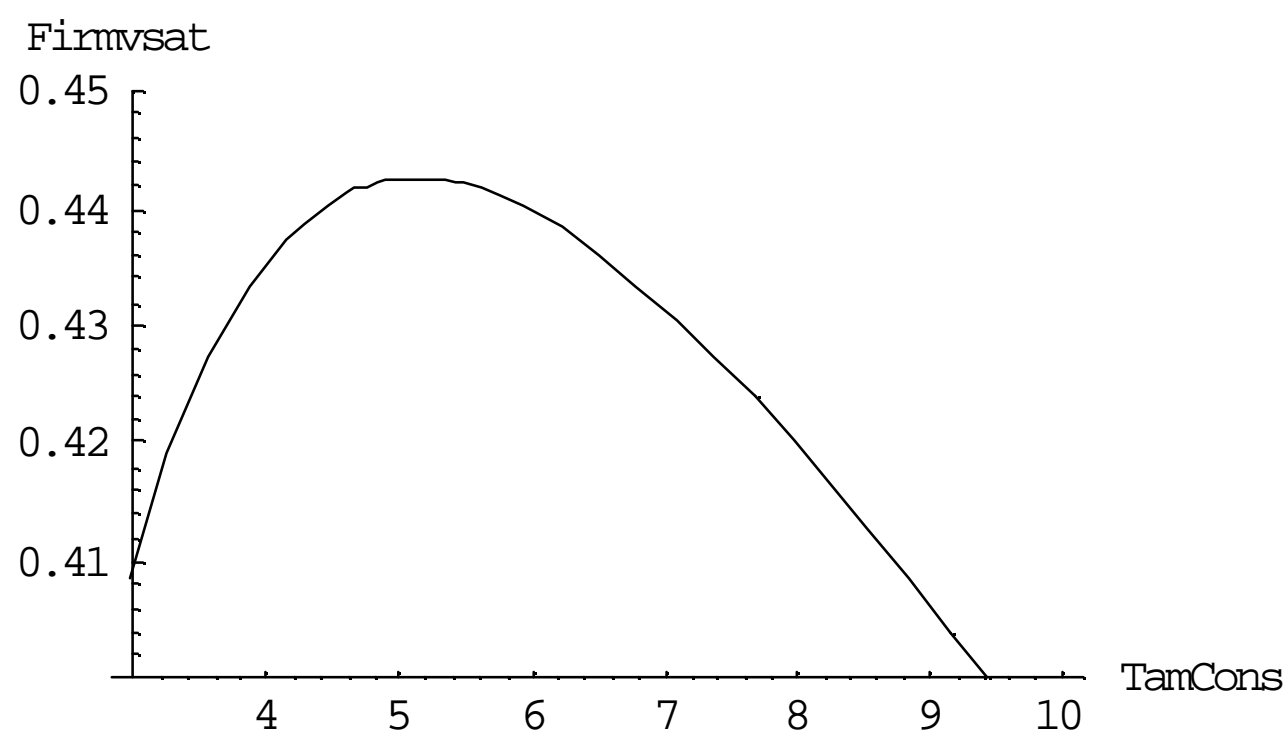

Tamanho ótimo do conselho para FIRMVSAT em 2000 - 5,15 membros

O teste de heterocedasticidade de White na regressão entre FIRMVSAT e as variáveis de governança em 2000 apresentou um resultado aceitável (valor de probabilidade 0,51 ), não rejeitando a hipótese nula da homocedasticidade do modelo (um número muito próximo de zero seria algo negativo para a qualidade estatística do modelo por rejeitar a hipótese nula da homocedasticidade). O R-quadrado ajustado de 0,35 pode ser considerado razoável, tendo em vista que o principal objetivo do teste não é elaborar um modelo preditivo do comportamento da variável dependente, mas sim analisar a significância de uma determinada variável independente na composição da variável dependente. $\mathrm{O}$ teste da normalidade dos resíduos de Jarque-Bera não rejeitou a hipótese nula de que os termos de erro se distribuem como uma Normal (valor de probabilidade 0,21). Caso o valor da probabilidade no teste de Jarque-Bera ficasse muito próxima de zero, seria rejeitada a hipótese nula da normalidade dos resíduos e o modelo seria considerado inadequado, devendo ser reespecificado. Com relação à questão da multicolinearidade, a utilização de duas variáveis intrinsecamente relacionadas $\left(\right.$ TOT e TOT $^{2}$ ) resultou em um Número de Condição (NC) alto (maior que 20) para todos os modelos, o que indicaria problemas de multicolinearidade. Essa multicolinearidade, entretanto, não afeta os resultados das outras variáveis, conforme comprovado pela construção de modelos sem o coeficiente quadrático de TOT, que apresentaram baixo NC (menor que 20) e resultados de direção, magnitude e nível de 
significância das outras variáveis praticamente inalterados. Como a utilização de TOT em escala quadrática é fundamental para testar a hipótese da faixa ótima para o tamanho do conselho e a multicolinearidade somente é causada pelas variáveis TOT e TOT $^{2}$ (não contaminando os resultados dos outros coeficientes), a questão da multicolinearidade não foi considerada um problema para todos os modelos.

Quadro21 - Relação entre a variável valor da empresa sobre ativo total (FIRMVSAT) e as variáveis de governança em 2000 sem a utilização da escala logarítmica para a variável TOT

\begin{tabular}{crrrr}
\hline \hline Variável & Coeficiente & $\begin{array}{c}\text { Erro } \\
\text { Padrão }\end{array}$ & Estatística t & Prob. \\
\hline \hline C & 0.353469 & 0.076318 & 4.631552 & 0.0000 \\
DE & -0.123506 & 0.031052 & -3.977373 & $\mathbf{0 . 0 0 0 1}$ \\
INDEP & -0.026072 & 0.051510 & -0.506159 & 0.6135 \\
TOT & 0.025642 & 0.017885 & 1.433704 & $\mathbf{0 . 1 5 3 7}$ \\
TOT^2 & -0.002081 & 0.001048 & -1.985989 & $\mathbf{0 . 0 4 8 8}$ \\
SERV & 0.101740 & 0.028900 & 3.520462 & 0.0006 \\
DIVTSAT & 0.004966 & 0.000802 & 6.192401 & 0.0000 \\
& & & & \\
\hline \hline R-quadrado & 0.377221 & Critério de Schwarz & -0.743540 \\
R-quadrado ajustado & 0.352956 & Prob(estatística F) & 0.000000 \\
& & & \\
& &
\end{tabular}

Equação:

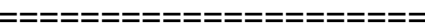

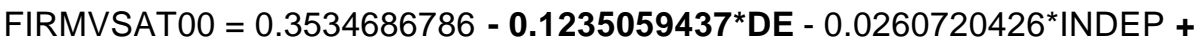

$0.02564182427^{\star}$ TOT $-0.002080595036^{\star}\left(\right.$ TOT $\left.^{\wedge} 2\right)+0.1017396566^{\star} \mathrm{SERV}+$ $0.004965818856 *$ DIVTSAT

Teste de Heterocedasticidade de White:

\begin{tabular}{llll}
\hline \hline \# Obs * R-quadrado & 21.67472 & Probabilidade & 0.598675
\end{tabular}




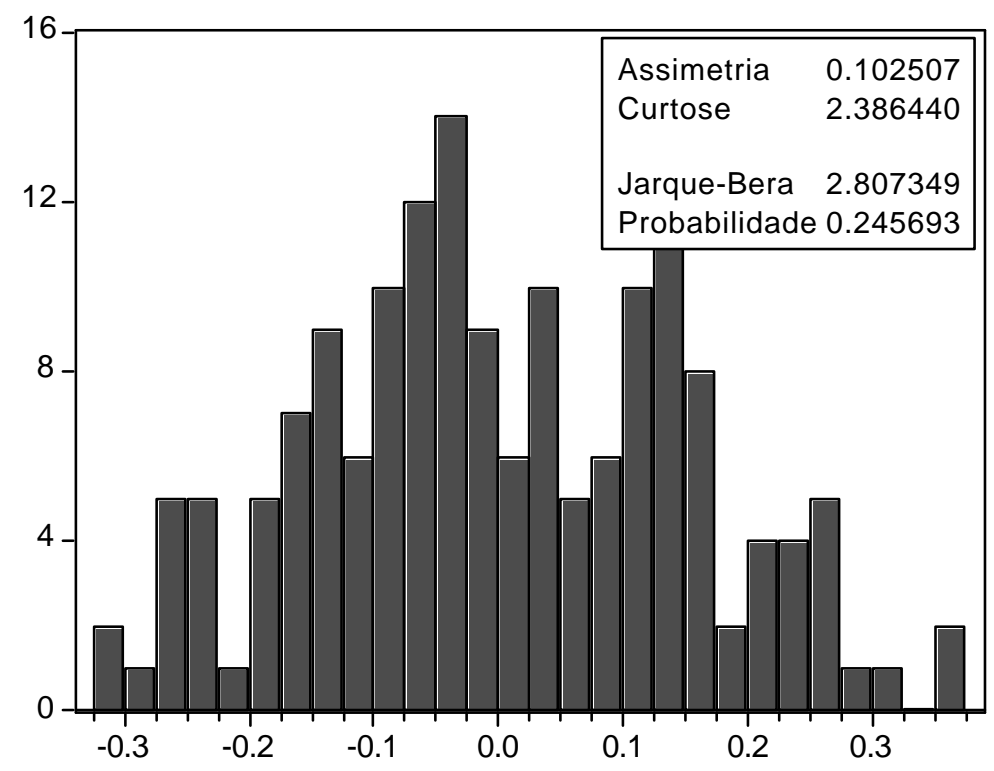

Figura 8 - Relação entre a variável valor da empresa sobre ativo total (FIRMVSAT) e a variável tamanho do conselho (TOT) em 2000 sem a utilização da escala logarítmica

Firmvsat

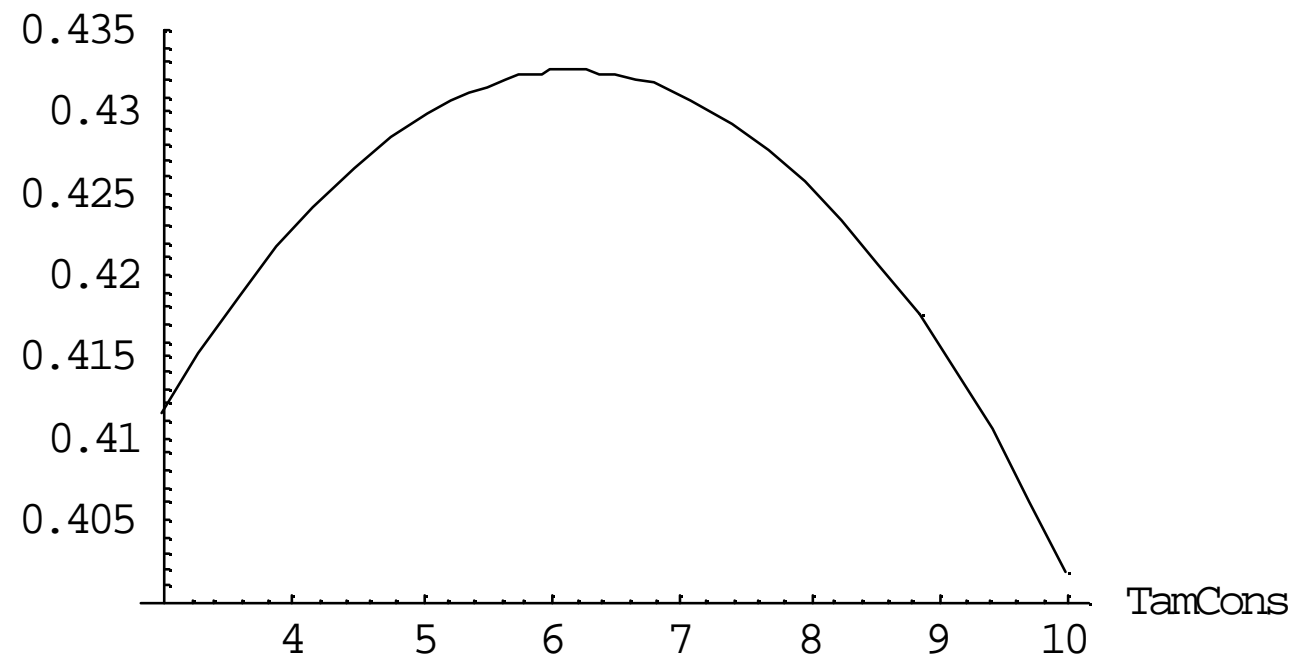

Tamanho ótimo do conselho para FIRMVSAT no modelo sem utilização da escala logarítmica em 2000 - 6,16 membros

Na variante do modelo FIRMVSAT contra as variáveis de governança em 2000 sem a utilização da variável TOT em escala logarítmica, o teste de heterocedasticidade de White apresentou um resultado aceitável (probabilidade 0,60), não rejeitando a hipótese nula da homocedasticidade do modelo. O R-quadrado ajustado de 0,35 também pode ser considerado aceitável. O teste da normalidade dos resíduos de Jarque-Bera não 
rejeitou a hipótese nula de que os termos de erro se distribuem como uma Normal (valor de probabilidade 0,24$)$. Assim como o modelo original com TOT em escala logarítmica, esta variante também pode ser considerada um modelo adequado aos pressupostos de um Modelo de Regressão Linear.

Quadro 22 - Relação entre a variável $Q$ de Tobin $(Q)$ e as variáveis de governança em 2000

\begin{tabular}{crrrr}
\hline \hline Variável & Coeficiente & $\begin{array}{c}\text { Erro } \\
\text { Padrão }\end{array}$ & Estatística t & Prob. \\
\hline \hline C & 0.715994 & 0.245812 & 2.912771 & 0.0041 \\
DE & -0.163405 & 0.039794 & -4.106228 & $\mathbf{0 . 0 0 0 1}$ \\
INDEP & -0.011203 & 0.067749 & -0.165362 & 0.8689 \\
LOG(TOT) & -0.118685 & 0.276261 & -0.429611 & 0.6681 \\
LOG(TOT)^2 & -0.007985 & 0.075279 & -0.106074 & 0.9157 \\
DIVTSAT & 0.008226 & 0.000834 & 9.868334 & 0.0000 \\
& & & & \\
\hline \hline R-quadrado & 0.463767 & Critério de Schwarz & -0.209281 \\
R-quadrado ajustado & 0.447010 & Prob(estatística F) & 0.000000 \\
& & & \\
\hline \hline
\end{tabular}

Equação:

$===============$

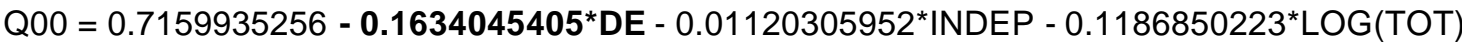

$-0.007985154537^{\star}\left(\right.$ LOG $\left.(\text { TOT })^{\wedge} 2\right)+0.008226055888^{\star}{ }^{\text {DIVTSAT }}$

Teste de Heterocedasticidade de White:

\begin{tabular}{llll}
\hline \hline \# Obs * R-quadrado & 25.86655 & Probabilidade & 0.102849
\end{tabular}

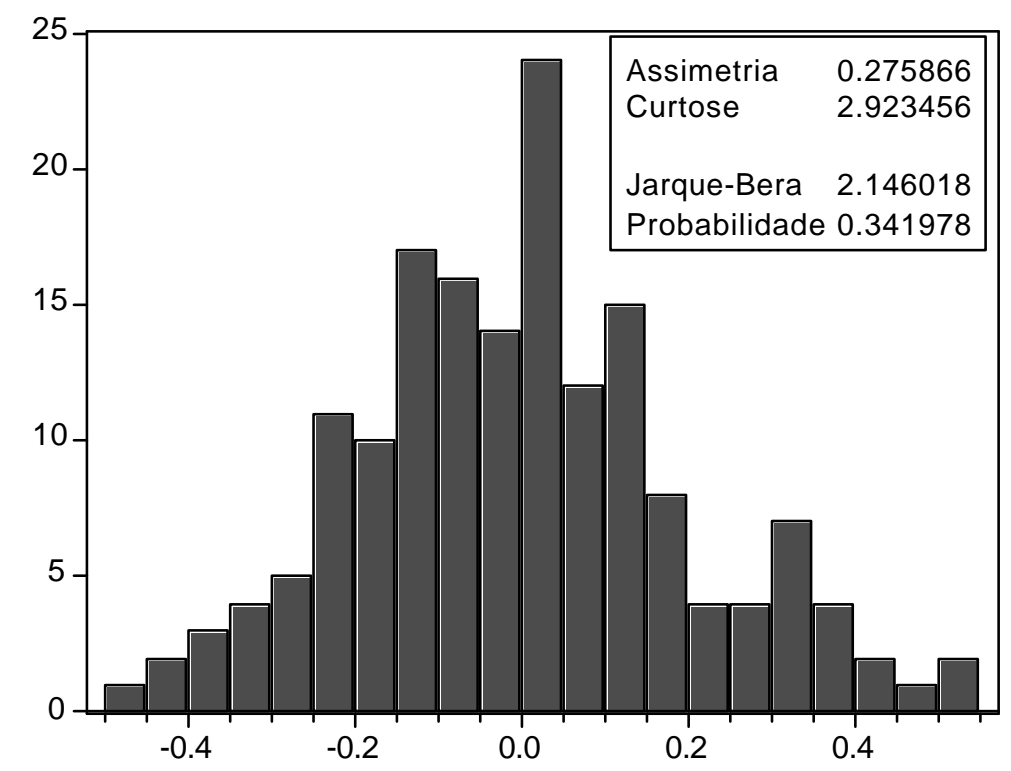


O teste de heterocedasticidade de White na regressão entre Q e as variáveis de governança em 2000 apresentou um resultado razoável (probabilidade 0,10), não rejeitando a hipótese nula da homocedasticidade dos dados no nível de $10 \%$ de significância. O R-quadrado ajustado de 0,45 também pode ser considerado aceitável. Além disso, o teste da normalidade dos resíduos de Jarque-Bera não rejeitou a hipótese nula de que os termos de erro se distribuem como uma Normal (valor de probabilidade $0,34)$, confirmando a qualidade estatística do modelo.

Quadro 23 - Relação entre a variável $Q$ de Tobin $(Q)$ e as variáveis de governança em 2000 sem a utilização da escala logarítmica para a variável TOT

\begin{tabular}{crrrr}
\hline \hline Variável & Coeficiente & $\begin{array}{c}\text { Erro } \\
\text { Padrão }\end{array}$ & Estatística t & Prob. \\
\hline \hline C & 0.670925 & 0.097045 & 6.913518 & 0.0000 \\
DE & -0.163543 & 0.039832 & -4.105819 & $\mathbf{0 . 0 0 0 1}$ \\
INDEP & -0.015116 & 0.067317 & -0.224543 & 0.8226 \\
TOT & -0.037016 & 0.022934 & -1.614017 & 0.1085 \\
TOT^2 & 0.000983 & 0.001354 & 0.725775 & 0.4690 \\
DIVTSAT & 0.008238 & 0.000838 & 9.825923 & 0.0000 \\
& & & & \\
\hline \hline R-quadrado & 0.462917 & Critério de Schwarz & -0.207698 \\
R-quadrado ajustado & 0.446134 & Prob(estatística F) & 0.000000 \\
& & & & \\
\hline \hline
\end{tabular}

Equação:

$================$

$\mathrm{Q} 00=0.6709247037-\mathbf{0 . 1 6 3 5 4 3 1 7 9}{ }^{\star} \mathrm{DE}-0.01511565023^{\star}$ INDEP $-0.03701643305^{*} \mathrm{TOT}+$ $0.0009827774562^{*}\left(\right.$ TOT $\left.^{\wedge} 2\right)+0.008238194191^{*}$ DIVTSAT

Teste de Heterocedasticidade de White:

\begin{tabular}{llll}
\hline \hline \#Obs. ${ }^{*}$ R-quadrado & 20.54239 & Probabilidade & 0.303125
\end{tabular}




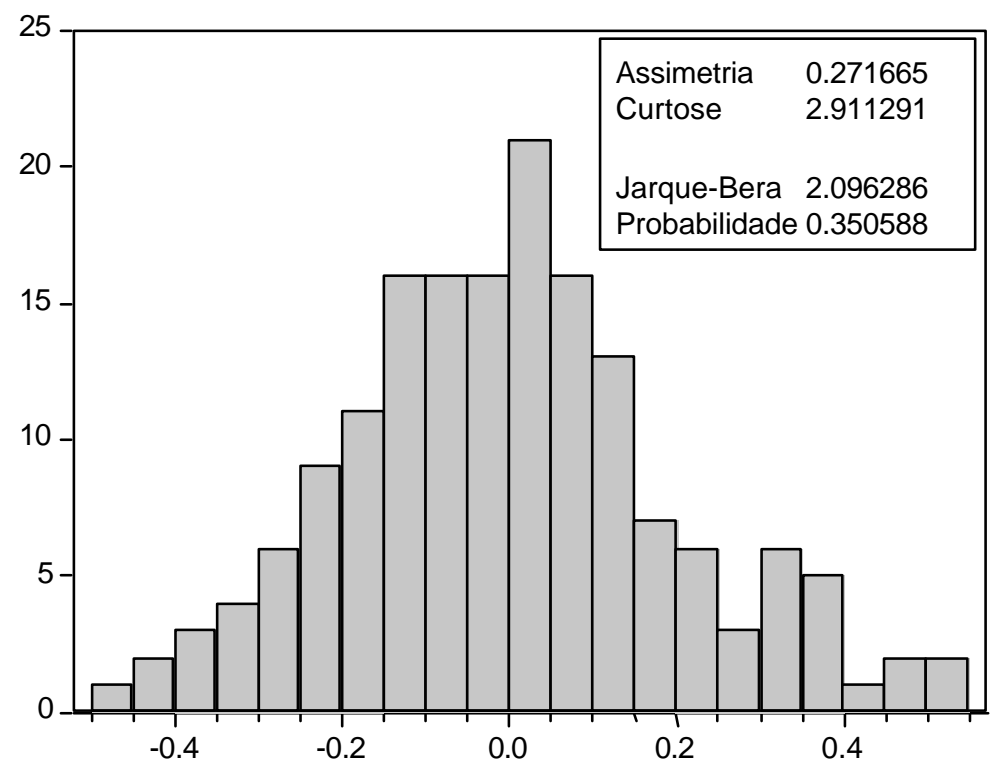

$\mathrm{Na}$ variante do modelo Q contra as variáveis de governança em 2000 sem a utilização da variável TOT em escala logarítmica, o teste de heterocedasticidade de White apresentou um resultado razoável (probabilidade 0,30), não rejeitando a hipótese nula da homocedasticidade dos dados. O R-quadrado ajustado de 0,45 também pode ser considerado aceitável. Além disso, o teste da normalidade dos resíduos de Jarque-Bera não rejeitou a hipótese nula de que os termos de erro se distribuem como uma Normal (valor de probabilidade 0,35 ), confirmando a qualidade estatística do modelo.

\subsubsection{Relação entre governança corporativa e desempenho em 2000}

O retorno sobre o ativo utilizando o lucro operacional próprio (RSAPR) foi a variável de desempenho que obteve o melhor resultado contra as variáveis de governança em 2000. Na regressão contra RSAPR, a variável diretor executivo como presidente do conselho (DE) apresentou uma correlação negativa no nível de significância de 10\%, indicando que as empresas que tiveram pessoas distintas ocupando os cargos de diretor executivo e presidente do conselho obtiveram, em média, melhor RSAPR no período. Desta forma, corroboroutse a hipótese de que a adoção das recomendações do IBGC e CVM neste tema resulta em uma melhor estrutura de governança, que pode levar a um melhor resultado financeiro para a companhia. Outro resultado importante foi a significância estatística (probabilidade de 5\%) da variável 
independente tamanho do conselho (TOT) contra o RSAPR. Além da relação significativa, esta variável apresentou um comportamento igual ao previsto nas recomendações do IBGC e CVM (que sugerem uma faixa ótima de tamanho para o conselho), com sinal do coeficiente linear positivo e sinal do coeficiente quadrático negativo, indicando a existência de uma faixa de tamanho ótimo que maximizaria o RSAPR no período. Foi construído um gráfico para visualizar a faixa ótima obtida para o tamanho do conselho, obtendo-se uma faixa ótima de seis a oito membros, com o valor máximo de RSAPR correspondendo a um conselho com 7,22 membros. Neste período, a variável independência do conselho (INDEP) não apresentou relação estatística significativa contra as variáveis de desempenho.

Quadro 24 - Relação entre a variável retorno sobre o ativo utilizando o lucro operacional próprio (RSAPR) e as variáveis de governança em 2000

\begin{tabular}{crrrr}
\hline \hline Variável & Coeficiente & $\begin{array}{c}\text { Erro } \\
\text { Padrão }\end{array}$ & Estatística t & Prob. \\
\hline \hline C & -0.046692 & 0.067436 & -0.692386 & 0.4896 \\
DE & -0.020871 & 0.011488 & -1.816723 & $\mathbf{0 . 0 7 0 9}$ \\
INDEP & 0.006327 & 0.020013 & 0.316127 & 0.7523 \\
LOG(TOT) & 0.156368 & 0.075200 & 2.079371 & $\mathbf{0 . 0 3 9 0}$ \\
LOG(TOT)^2 & -0.039536 & 0.020205 & -1.956738 & $\mathbf{0 . 0 5 1 9}$ \\
SERV & -0.036566 & 0.010507 & -3.480315 & 0.0006 \\
RECEITA & $3.82 E-09$ & $1.37 E-09$ & 2.780057 & 0.0060 \\
DIVTSAT & -0.000805 & 0.000208 & -3.874698 & 0.0001 \\
& & & & \\
\hline \hline R-quadrado & 0.192913 & Critério de Schwarz & -2.489806 \\
R-quadrado ajustado & 0.162209 & Prob(estatística F) & 0.000001 \\
& & & & \\
\hline \hline
\end{tabular}

Equação:

$==================$

RSAPRO0 $=-0.04669194797-\mathbf{0 . 0 2 0 8 7 1 1 2 7 1}$ *DE + 0.00632667146*INDEP +

$0.1563682198^{\star}$ LOG(TOT) - 0.03953606526*(LOG(TOT)^2) - $0.03656596834^{\star} \mathrm{SERV} \mathrm{+}$ 3.816284901e-09*RECEITA - 0.0008047417746 *DIVTSAT

Teste de Heterocedasticidade de White:

\begin{tabular}{llll}
\hline \hline \# Obs * R-quadrado & 38.30672 & Probabilidade & 0.204980
\end{tabular}




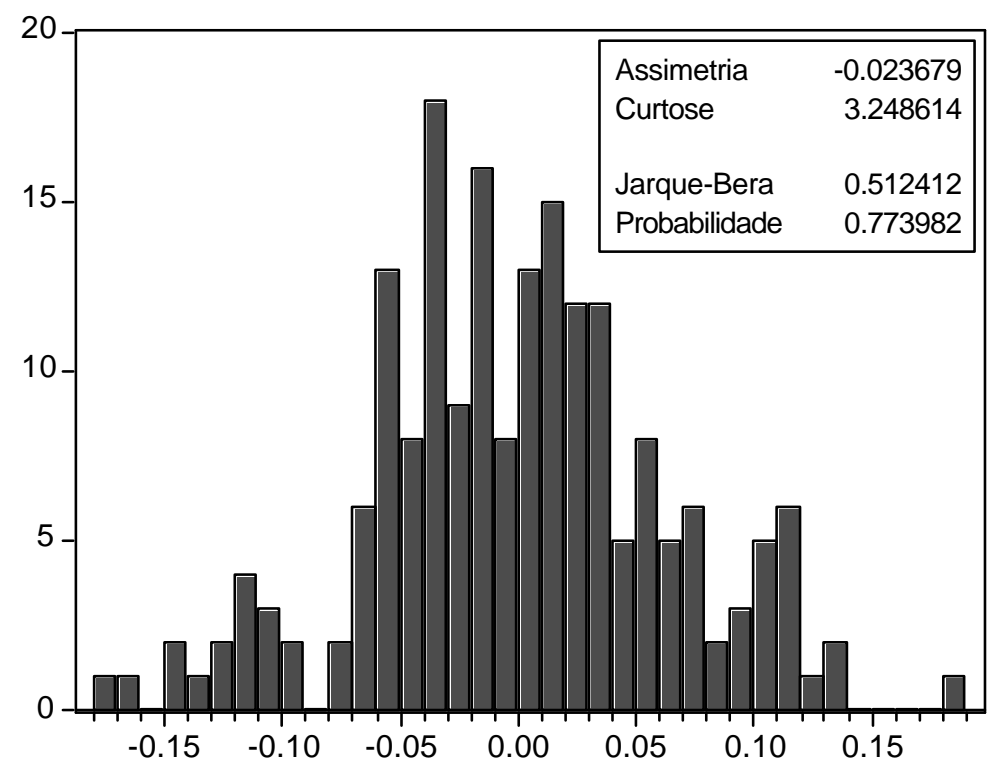

Figura 9 - Relação entre a variável valor da empresa sobre ativo total (RSAPR) e a variável tamanho do conselho (TOT) em 2000

RSAPR

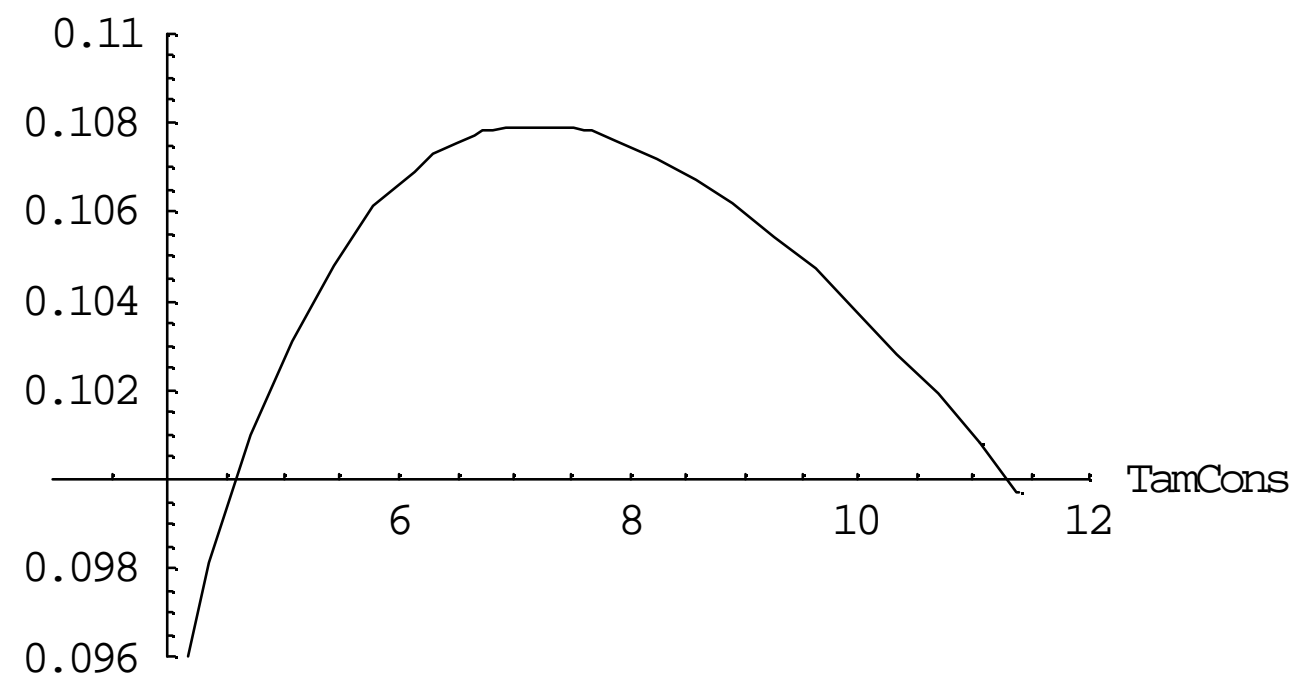

Tamanho ótimo do conselho para RSAPR em 2000 - 7,22 membros

O teste de heterocedasticidade de White na regressão RSAPR contra as variáveis de governança em 2000 apresentou um resultado razoável (probabilidade 0,20), não rejeitando a hipótese nula da homocedasticidade dos dados. Por outro lado, o Rquadrado ajustado foi de apenas 0,16 , sendo considerado baixo. $O$ teste da normalidade dos resíduos de Jarque-Bera apresentou um resultado positivo para a qualidade 
estatística do modelo (probabilidade 0,77), não rejeitando a hipótese nula de que os resíduos são normais.

\subsubsection{Resultados de 1999}

\subsubsection{Matriz de Correlações em 1999}

As correlações obtidas em 1999 foram consistentes com as encontradas em 2000. Como forma de evitar repetição dos comentários, quando as correlações entre as variáveis se mostrarem semelhantes às de 2000, serão indicados os comentários da seção 4.2.1.1.

Quadro 25 - correlações entre as variáveis de governança no ano de 1999

\begin{tabular}{lccc}
\hline & INDEP & TOT & DE \\
\hline INDEP & 1.0000 & 0.3861 & -0.5564 \\
\hline TOT & & 1.0000 & -0.2601 \\
\hline DE & & & 1.0000 \\
\hline
\end{tabular}

As correlações do quadro 25 indicam que:

1. quanto maior a independência do conselho (INDEP), menor a probabilidade dos cargos de diretor executivo e presidente do conselho (DE) serem ocupados pela mesma pessoa - vide comentário 1 do quadro 17;

2. quanto maior a probabilidade dos cargos de diretor executivo e presidente do conselho (DE) serem ocupados pela mesma pessoa, menor o tamanho do conselho (TOT) - vide comentário 2 do quadro 17.

Quadro 26 - correlações entre as variáveis de governança, estrutura de propriedade e valor no ano de 1999

\begin{tabular}{|c|c|c|c|c|c|c|c|c|}
\hline & INDEP & TOT & DE & ACCONTR & AA & ACAA & Q99 & FIRMVSAT \\
\hline INDEP & 1.0000 & 0.3797 & -0.5539 & -0.0379 & 0.3077 & -0.0014 & 0.0879 & 0.0739 \\
\hline TOT & & 1.0000 & -0.2542 & -0.1940 & 0.2339 & -0.1476 & 0.0123 & 0.0544 \\
\hline $\mathrm{DE}$ & & & 1.0000 & 0.0346 & -0.1586 & 0.0371 & -0.2186 & -0.1997 \\
\hline ACCONTR & & & & 1.0000 & -0.1324 & 0.9220 & -0.0306 & -0.0903 \\
\hline AA & & & & & 1.0000 & 0.0195 & 0.0648 & 0.1367 \\
\hline ACAA & & & & & & 1.0000 & 0.0026 & -0.0103 \\
\hline Q99 & & & & & & & 1.0000 & 0.7601 \\
\hline FIRMVSAT & & & & & & & & 1.0000 \\
\hline
\end{tabular}

As correlações do quadro 26 indicam que:

1. quanto maior a independência do conselho (INDEP), maior a probabilidade da existência de acordo de acionistas (AA) - vide comentário 1 do quadro 18; 
2. quanto maior a independência do conselho (INDEP), maior o valor da firma (Q e FIRMVSAT). Embora muito fracamente correlacionados, o sentido da relação entre as variáveis tende a corroborar a hipótese de que a independência do conselho é saudável para as empresas, aumentando seu valor de mercado;

3. quanto maior a concentração de ações ordinárias pelos controladores (ACCONTR), menor o tamanho do conselho (TOT) - vide comentário 2 do quadro 18;

4. quanto maior a unificação dos cargos de diretor executivo e presidente do conselho (DE), menor o valor da empresa (Q e FIRMVSAT) - vide comentário 3 do quadro 18 ;

5. quanto maior a unificação dos cargos de presidente do conselho e diretor executivo (DE), menor a presença de acordo de acionistas (AA) - vide comentário 5 do quadro 18.

Quadro 27 - correlações entre as variáveis de governança, estrutura de propriedade e desempenho no ano de 1999

\begin{tabular}{|c|c|c|c|c|c|c|c|c|c|c|c|}
\hline & INDEP & TOT & DE & ACCONTR & AA & ACAA & RSAOP & RSAPR & RSPLOP & RSPLPR & EBTSAT \\
\hline INDEP & 1.0000 & 0.3721 & -0.5467 & -0.0398 & 0.3172 & 0.0023 & 0.0965 & 0.1937 & 0.0118 & 0.0531 & 0.0950 \\
\hline TOT & & 1.0000 & -0.2486 & -0.2058 & 0.2603 & -0.1552 & 0.1067 & 0.0729 & -0.0741 & 0.0673 & -0.0245 \\
\hline $\mathrm{DE}$ & & & 1.0000 & 0.0338 & -0.1826 & 0.0241 & -0.0155 & -0.1088 & 0.0748 & -0.0420 & -0.0517 \\
\hline ACCONTR & & & & 1.0000 & -0.1639 & 0.9284 & 0.0076 & -0.0503 & -0.0290 & 0.0400 & -0.0750 \\
\hline AA & & & & & 1.0000 & -0.0287 & -0.0515 & 0.0264 & -0.0628 & 0.0479 & 0.0969 \\
\hline ACAA & & & & & & 1.0000 & -0.0365 & -0.0937 & -0.0898 & 0.0199 & -0.0475 \\
\hline RSAOP & & & & & & & 1.0000 & 0.6151 & -0.0160 & 0.1643 & 0.3832 \\
\hline RSAPR & & & & & & & & 1.0000 & 0.0819 & 0.4552 & 0.7285 \\
\hline RSPLOP & & & & & & & & & 1.0000 & -0.2908 & -0.0064 \\
\hline RSPLPR & & & & & & & & & & 1.0000 & 0.3365 \\
\hline EBITSAT & & & & & & & & & & & 1.0000 \\
\hline
\end{tabular}

As correlações do quadro 27 indicam que:

1. quanto maior a independência do conselho (INDEP), maior o retorno (baseado no lucro operacional próprio) sobre o ativo (RSAPR) - vide comentário 1 do quadro 19;

2. a relação entre o tamanho do conselho (TOT) e as variáveis de desempenho é ambígua, sem uma relação definida;

3. quanto maior a unificação dos cargos de diretor executivo e presidente do conselho (DE), pior o desempenho da empresa (RSAPR) - vide comentário 3 do quadro 19. 


\subsubsection{Relação entre governança corporativa e valor em 1999}

Em 1999, nenhuma variável de governança obteve significância estatística no nível de 5\% (probabilidade associada à estatística $t$ ) contra as variáveis dependentes de valor $\mathrm{Q}$ de Tobin (Q) e valor da empresa sobre ativo btal (FIRMVSAT). Deve-se ressaltar, entretanto, que a variável diretor executivo como presidente do conselho (DE) teve um resultado consistente com os obtidos em 2000, apresentando uma correlação negativa $(15 \%)$ contra as variáveis de valor. Este resultado indica que as empresas que tiveram pessoas distintas ocupando os cargos de presidente do conselho e diretor executivo obtiveram, em média, maior valor de mercado no período, corroborando as recomendações do IBGC e CVM neste tema. A variável tamanho do conselho (TOT) não apresentou relação significativa contra as variáveis de valor. A variável independência do conselho (INDEP) apresentou uma correlação positiva significativa $(10 \%)$ contra a variável de valor Q de Tobin, indicando que as empresas com maior proporção de externos no conselho obtiveram, em média, maior Q de Tobin em 1999.

Quadro 28 - Relação entre a variável Q de Tobin $(Q)$ e as variáveis de governança em 1999

\begin{tabular}{crrrr}
\hline \hline Variável & Coeficiente & $\begin{array}{c}\text { Erro } \\
\text { Padrão }\end{array}$ & Estatística t & Prob. \\
& \multicolumn{4}{c}{. } \\
\hline C & 0.261386 & 0.244459 & 1.069241 & 0.2865 \\
DE & -0.051573 & 0.037351 & -1.380777 & $\mathbf{0 . 1 6 9 2}$ \\
INDEP & 0.121457 & 0.071674 & 1.694569 & $\mathbf{0 . 0 9 2 0}$ \\
LOG(TOT) & 0.023583 & 0.270400 & 0.087215 & 0.9306 \\
LOG(TOT)^2 & -0.020165 & 0.073429 & -0.274619 & 0.7839 \\
DIVTSAT & 0.008051 & 0.000803 & 10.02144 & 0.0000 \\
SERV & 0.186988 & 0.034527 & 5.415629 & 0.0000 \\
& & & & \\
\hline \hline R-quadrado & 0.438809 & Critério de Schwarz & 0.553410 \\
R-quadrado ajustado & 0.419002 & Prob (estatística F) & 0.000000 \\
& & & \\
\end{tabular}

Equação:

$===================$

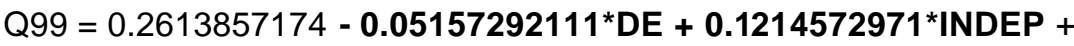
$0.02358281308^{\star}$ LOG(TOT) $-0.02016498704^{*}\left(\right.$ LOG $\left.(\text { TOT })^{\wedge} 2\right)+0.008050994524{ }^{*}$ DIVTSAT + $0.1869880213^{\star}$ SERV

Teste de Heterocedasticidade de White:

\begin{tabular}{llll}
\hline \hline \# Obs * R-quadrado & 15.21723 & Probabilidade & 0.914241
\end{tabular}




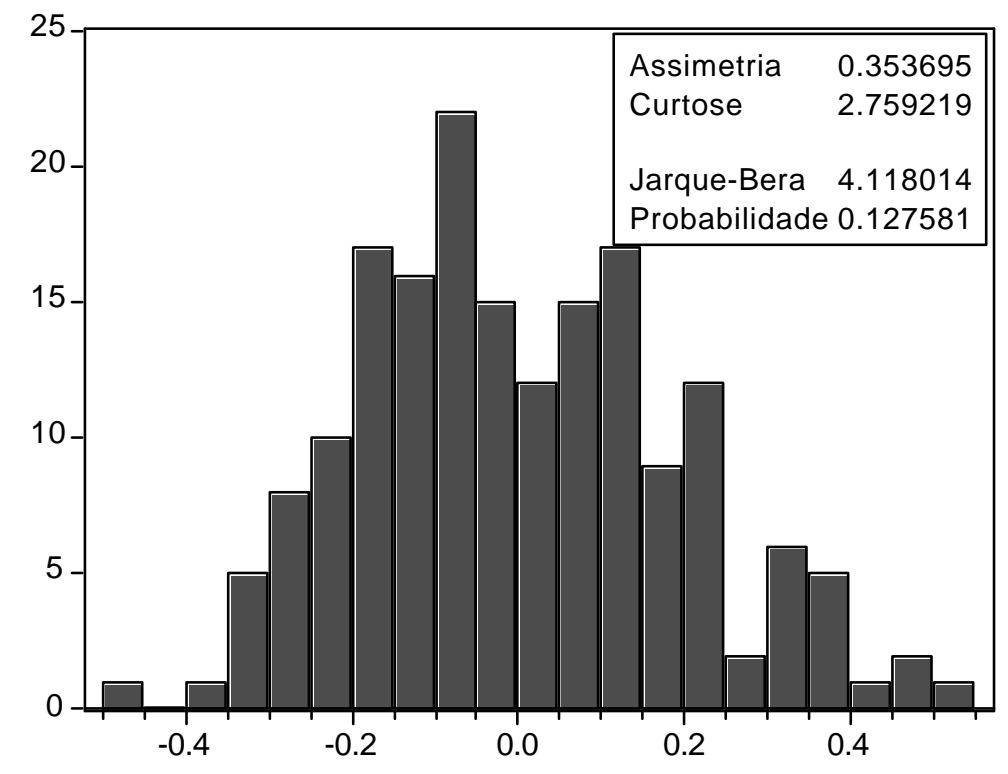

O teste de heterocedasticidade de White na regressão entre Q e as variáveis de governança em 1999 (probabilidade 0,91) não rejeitou a hipótese nula da homocedasticidade do modelo. O R-quadrado ajustado $(0,42)$ pode ser considerado razoável. O teste da normalidade dos resíduos de Jarque-Bera não rejeitou a hipótese nula da normalidade na distribuição dos termos de erro (valor de probabilidade 0,12 ), confirmando a qualidade estatística do modelo.

Quadro 29 - Relação entre a variável valor da empresa sobre ativo total (FIRMVSAT) e as variáveis de governança em 1999

\begin{tabular}{crrrr}
\hline \hline Variável & Coeficiente & $\begin{array}{c}\text { Erro } \\
\text { Padrão }\end{array}$ & Estatística t & Prob. \\
\hline \hline C & 0.542852 & 0.180029 & 3.015361 & 0.0030 \\
DE & -0.041194 & 0.028366 & -1.452241 & $\mathbf{0 . 1 4 8 3}$ \\
INDEP & 0.018996 & 0.054762 & 0.346880 & 0.7291 \\
LOG(TOT) & -0.283902 & 0.201263 & -1.410605 & 0.1602 \\
LOG(TOT)2 & 0.059243 & 0.055152 & 1.074178 & 0.2843 \\
DIVTSAT & 0.007594 & 0.000556 & 13.66491 & 0.0000 \\
SERV & 0.146527 & 0.026866 & 5.453991 & 0.0000 \\
& & & & \\
\hline \hline R-quadrado & 0.575376 & Critério de Schwarz & -0.796452 \\
R-quadrado ajustado & 0.560028 & Prob (estatística F) & 0.000000 \\
& & & & \\
\hline \hline
\end{tabular}

\section{Equação:}

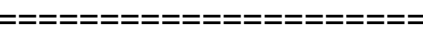

FIRMVSAT99 $=0.5428517245-\mathbf{0 . 0 4 1 1 9 4 4 6 1 3 4}$ *DE $+0.0189958731^{*}$ INDEP -

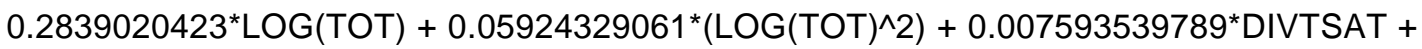
$0.146526876 *$ SERV 
Teste de Heterocedasticidade de White:

\begin{tabular}{lccc}
\hline \hline \# Obs * R-quadrado & 23.60712 & Probabilidade & 0.484237 \\
\hline \hline
\end{tabular}

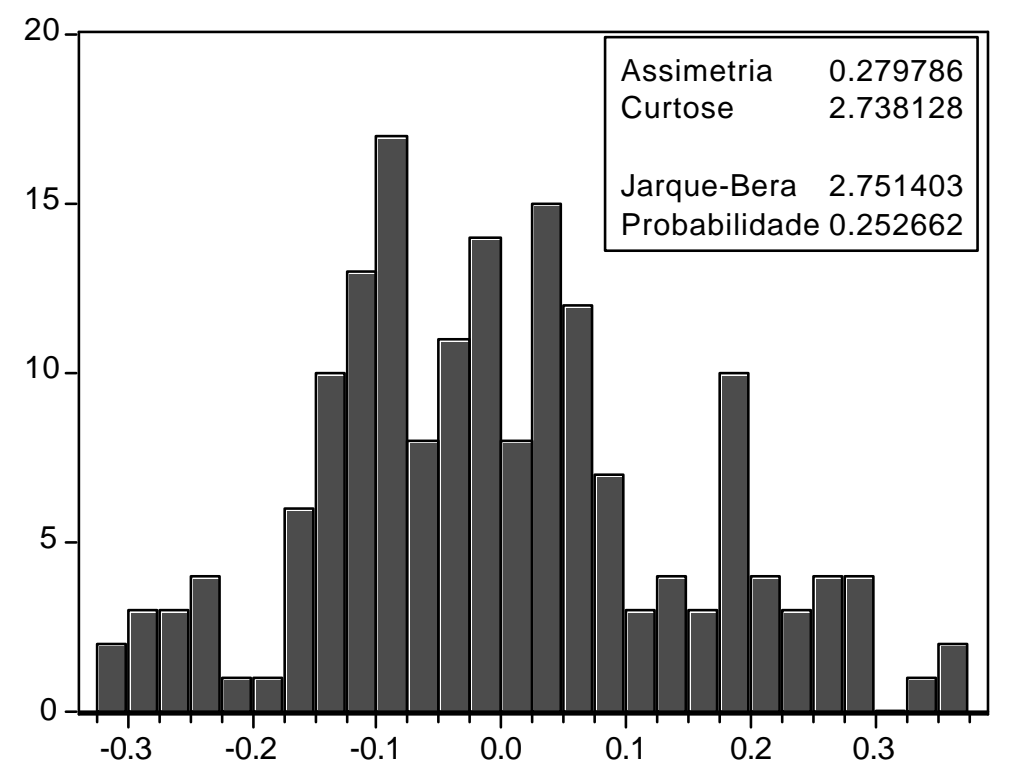

O teste de heterocedasticidade de White na regressão entre FIRMVSAT e as variáveis de governança em 1999 (probabilidade 0,48) não rejeitou a hipótese nula da homocedasticidade do modelo. O R-quadrado ajustado $(0,56)$ pode ser considerado bastante razoável. O teste da normalidade dos resíduos de Jarque-Bera não rejeitou a hipótese nula de que os erros se distribuem como uma Normal (valor de probabilidade 0,25), confirmando a qualidade estatística do modelo.

\subsubsection{Relação entre governança corporativa e desempenho em 1999}

A variável tamanho do Conselho de Administração (TOT) foi a única variável de governança com resultados significativos no ano de 1999 contra as variáveis de desempenho, apresentando uma correlação negativa significante no nível de 5\% contra a variável dependente lucro antes dos juros, impostos, depreciação e amortização sobre o ativo (EBITSAT). Os sinais dos coeficientes foram consistentes aos obtidos em 2000 (sinal do coeficiente linear positivo e sinal do coeficiente quadrático negativo), conforme as recomendações do IBGC e CVM da existência de uma faixa ótima para o tamanho do conselho. Foi construído um gráfico para visualizar a faixa ótima obtida 
para o tamanho do conselho, obtendo-se uma faixa ótima de cinco a sete membros, com o valor máximo de EBITSAT correspondendo a um conselho com 5,96 membros. Neste período, as variáveis diretor executivo como presidente do conselho (DE) e independência do conselho (INDEP) não apresentaram relação estatística significativa contra as variáveis de desempenho.

Quadro 30 - Relação entre a variável lucro antes dos juros, impostos, depreciação e amortização (EBITSAT) e as variáveis de governança em 1999

\begin{tabular}{crrrr}
\hline \hline Variável & Coeficiente & $\begin{array}{c}\text { Erro } \\
\text { Padrão }\end{array}$ & Estatística t & Prob. \\
\hline \hline C & -0.068405 & 0.113310 & -0.603692 & 0.5468 \\
DE & -0.008069 & 0.018039 & -0.447296 & 0.6552 \\
INDEP & 0.031234 & 0.034437 & 0.906980 & 0.3657 \\
LOG(TOT) & 0.263151 & 0.125455 & 2.097582 & $\mathbf{0 . 0 3 7 4}$ \\
LOG(TOT)^2 & -0.073669 & 0.034071 & -2.162230 & $\mathbf{0 . 0 3 2 0}$ \\
DIVTSAT & -0.001091 & 0.000362 & -3.011486 & 0.0030 \\
SERV & -0.023718 & 0.016931 & -1.400828 & 0.1630 \\
& & & & \\
\hline \hline R-quadrado & 0.089032 & Critério de Schwarz & -1.650552 \\
R-quadrado ajustado & 0.057799 & Prob(estatística F) & 0.011295 \\
& & & \\
& & & \\
\hline \hline
\end{tabular}

Equação:

$================$

EBITSAT99 $=-0.06840456536-0.008068728134^{*} \mathrm{DE}+0.031233637^{*} \mathrm{INDEP}+$

$0.2631512107^{\star}$ LOG(TOT) $-0.07366930385^{\star}\left(\right.$ LOG(TOT) $\left.{ }^{\wedge} 2\right)-0.001091485884^{\star}$ DIVTSAT -

$0.02371757502 *$ SERV

Teste de Heterocedasticidade de White:

\begin{tabular}{llll}
\hline \hline \# Obs * R-quadrado & 35.76640 & Probabilidade & 0.057817
\end{tabular}




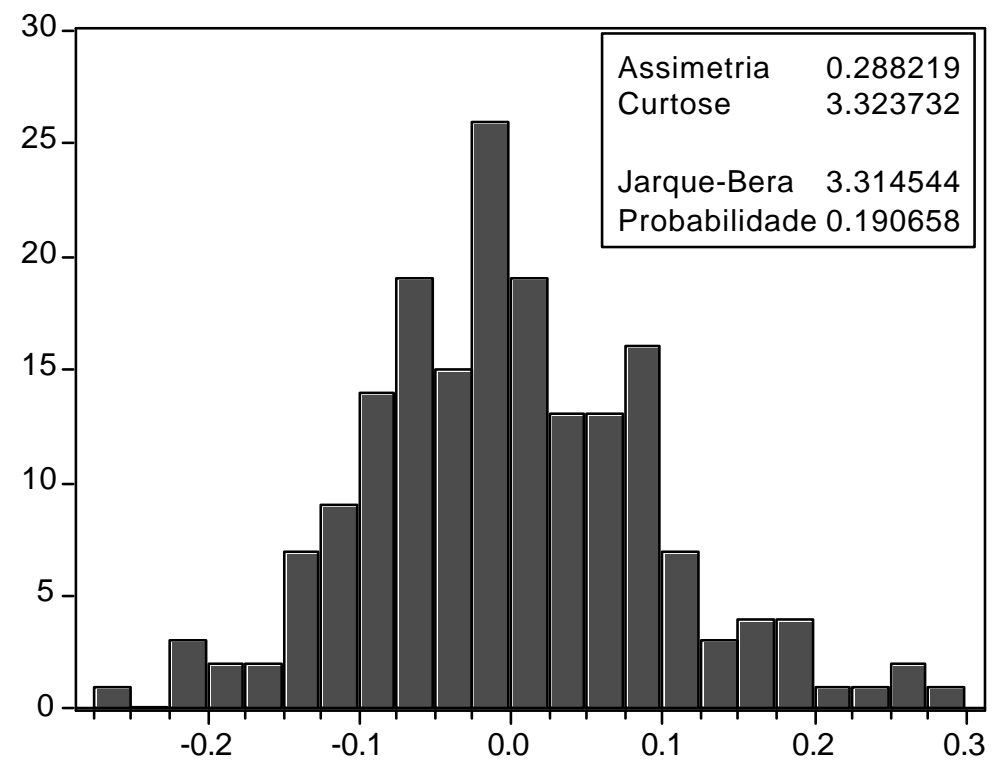

Figura 10 - Relação entre o lucro antes dos juros, impostos, depreciação e amortização sobre o ativo total (EBITSAT) e a variável tamanho do conselho (TOT) em 1999

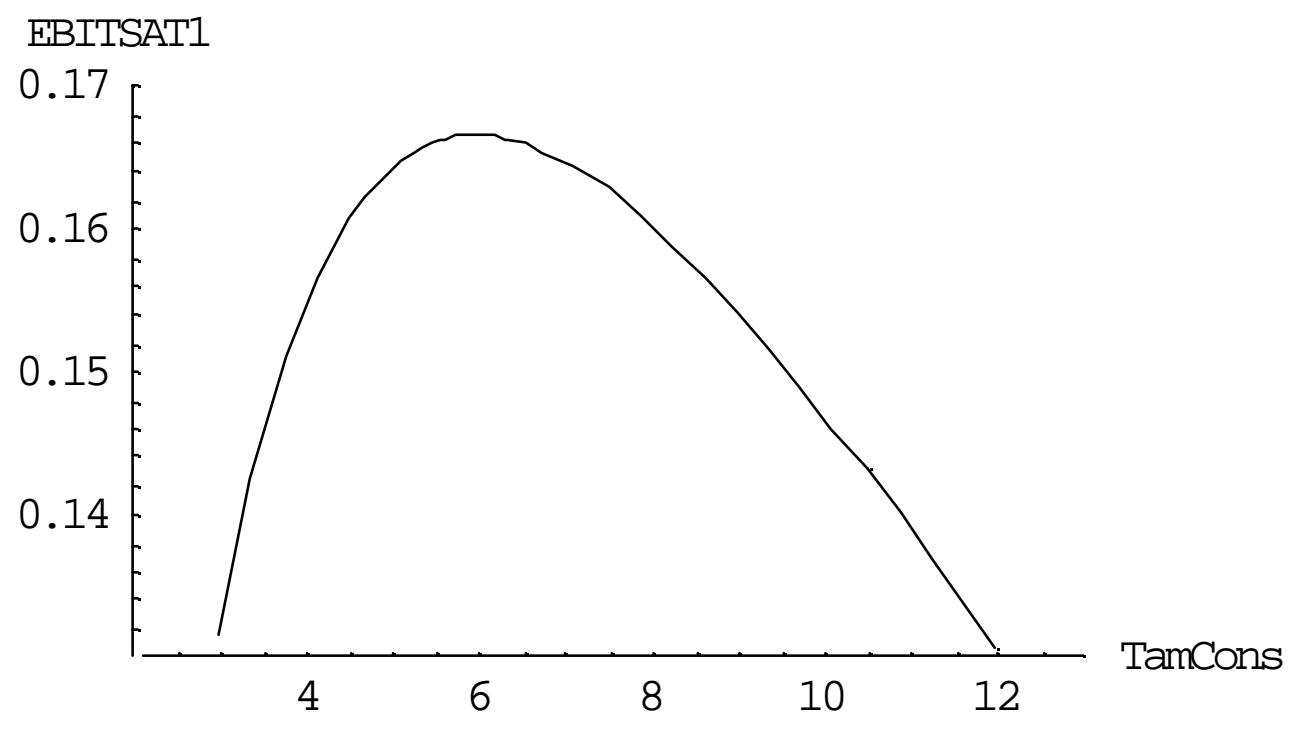

Tamanho ótimo do conselho para EBITSAT em 1999 - 5,96 membros

Esse modelo apresentou uma qualidade estatística inadequada, pois o teste de heterocedasticidade de White (probabilidade de 0,06) rejeitou a hipótese nula da homocedasticidade dos dados a um nível de significância de $10 \%$. Como o teste de White é um teste geral que mede a adequação do modelo à três pressupostos de um MRL (a homocedasticidade dos termos de erro, a especificação linear correta das variáveis e a independência dos resíduos com relação aos regressores), sua rejeição faz com que o modelo seja considerado inadequado. Além disso, o R-quadrado ajustado de 
0,06 também se mostrou muito baixo. O teste da normalidade dos resíduos de JarqueBera (probabilidade 0,19) não rejeitou a hipótese nula de resíduos normais.

\subsubsection{Resultados de 1998}

\subsubsection{Matriz de Correlações em 1998}

A magnitude e sentido das correlações obtidas em 1998 também são consistentes com as obtidas em 2000 e 1999. Como forma de evitar repetição dos comentários, quando as correlações entre as variáveis se mostrarem semelhantes às de 2000 , serão indicados os comentários da seção 4.2.2.1.

Quadro 31 - correlações entre as variáveis de governança no ano de 1998

\begin{tabular}{lccc}
\hline & INDEP & TOT & DE \\
INDEP & 1.0000 & 0.3292 & -0.6310 \\
\hline TOT & & 1.0000 & -0.2785 \\
\hline DE & & & 1.0000 \\
\hline
\end{tabular}

As correlações do quadro 31 indicam que:

1. quanto maior a independência do conselho (INDEP), menor a probabilidade dos cargos de diretor executivo e presidente do conselho (DE) serem ocupados pela mesma pessoa - vide comentário 1 do quadro 17;

2. quanto maior a probabilidade dos cargos de diretor executivo e presidente do conselho (DE) serem ocupados pela mesma pessoa, menor o tamanho do conselho (TOT) - vide comentário 2 do quadro 17.

Quadro 32 - correlações entre as variáveis de governança, estrutura de propriedade e valor no ano de 1998

\begin{tabular}{|c|c|c|c|c|c|c|c|c|}
\hline & INDEP & TOT & DE & ACCONTR & AA & ACAA & Q98 & FIRMVSAT \\
\hline INDEP & 1.0000 & 0.3217 & -0.6297 & -0.1177 & 0.1929 & -0.1021 & 0.1039 & 0.1136 \\
\hline TOT & & 1.0000 & -0.2721 & -0.2520 & 0.1990 & -0.2110 & 0.1045 & 0.1073 \\
\hline $\mathrm{DE}$ & & & 1.0000 & 0.0836 & -0.1194 & 0.0909 & -0.1649 & -0.1706 \\
\hline ACCONTR & & & & 1.0000 & -0.0452 & 0.9401 & 0.0397 & 0.0310 \\
\hline AA & & & & & 1.0000 & 0.0730 & 0.0222 & 0.0409 \\
\hline ACAA & & & & & & 1.0000 & 0.0428 & 0.0488 \\
\hline Q98 & & & & & & & 1.0000 & 0.8257 \\
\hline FIRMVSAT & & & & & & & & 1.0000 \\
\hline
\end{tabular}

As correlações do quadro 32 indicam que:

1. quanto maior a independência do conselho (INDEP), maior a probabilidade da existência de acordo de acionistas (AA) - vide comentário 1 do quadro 18; 
2. quanto maior a independência do conselho (INDEP), maior o valor da firma (Q e FIRMVSAT). Esta relação tende a corroborar a hipótese de que a independência do conselho é saudável para as empresas, aumentando seu valor de mercado;

3. quanto maior a concentração de ações ordinárias pelos controladores (ACCONTR), menor a independência do conselho (INDEP). Esta relação corrobora a hipótese de que quanto maior o poder do acionista controlador, menor a independência do Conselho de Administração;

4. quanto maior a concentração de ações ordinárias pelos controladores (ACCONTR), menor o tamanho do conselho (TOT) - vide comentário 2 do quadro 18;

5. quanto maior o tamanho do conselho (TOT), maior o valor da empresa (Q e FIRMVSAT). Esta relação contraria os resultados obtidos por Yermack (1996), de que empresas com conselhos menores possuem maior valor de mercado;

6. quanto maior a unificação dos cargos de diretor executivo e presidente do conselho (DE), menor o valor da empresa (Q e FIRMVSAT) - vide comentário 3 do quadro 18 ;

7. quanto maior a unificação dos cargos de diretor executivo e presidente do conselho (DE), menor a presença de acordo de acionistas (AA) - vide comentário 5 do quadro 18.

Quadro 33 - correlações entre as variáveis de governança, estrutura de propriedade e desempenho no ano de 1998

\begin{tabular}{|c|c|c|c|c|c|c|c|c|c|c|c|}
\hline & INDEP & TOT & DE & ACCONTR & $\mathbf{A A}$ & ACAA & RSAOP & RSAPR & RSPLOP & RSPLPR & EBITSAT \\
\hline INDEP & 1.0000 & 0.3517 & -0.6234 & -0.0919 & 0.2024 & -0.0764 & 0.0142 & 0.0298 & -0.0553 & -0.0058 & 0.0402 \\
\hline TOT & & 1.0000 & -0.2796 & -0.2375 & 0.2337 & -0.1936 & 0.0680 & 0.0332 & -0.0194 & 0.0798 & -0.0201 \\
\hline $\mathrm{DE}$ & & & 1.0000 & 0.0549 & -0.1167 & 0.0650 & 0.0984 & 0.0012 & -0.0708 & -0.1707 & 0.0310 \\
\hline ACCONIR & & & & 1.0000 & -0.0623 & 0.9402 & -0.0822 & -0.0701 & 0.0535 & -0.1344 & -0.1144 \\
\hline AA & & & & & 1.0000 & 0.0498 & -0.0483 & -0.0662 & -0.0257 & -0.0394 & -0.0226 \\
\hline ACAA & & & & & & 1.0000 & -0.1010 & -0.0970 & 0.0399 & -0.1523 & -0.1219 \\
\hline RSAOP & & & & & & & 1.0000 & 0.7148 & 0.0176 & 0.0989 & 0.6624 \\
\hline RSAPR & & & & & & & & 1.0000 & 0.1379 & 0.2769 & 0.8859 \\
\hline RSPLOP & & & & & & & & & 1.0000 & 0.1539 & 0.1132 \\
\hline RSPLPR & & & & & & & & & & 1.0000 & 0.1993 \\
\hline EBITSAT & & & & & & & & & & & 1.0000 \\
\hline
\end{tabular}

As correlações do quadro 33 indicam que:

1. a independência do conselho (INDEP) não apresenta relação clara com o desempenho da empresa no período analisado;

2. a relação entre o tamanho do conselho (TOT) e o desempenho é ambígua, sem uma relação definida; 
3. quanto maior a unificação dos cargos de diretor executivo e presidente do conselho (DE), pior o desempenho da empresa (RSPLPR) - vide comentário 3 do quadro 19;

4. quanto maior a concentração de ações ordinárias pelos controladores (ACCONTR), pior o desempenho medido pelo RSPLPR e EBITSAT.

\subsubsection{Relação entre governança corporativa e valor em 1998}

A variável diretor executivo como presidente do conselho (DE) foi a única variável de governança com significância estatística em 1998, apresentando uma correlação negativa no nível de $10 \%$ (probabilidade da estatística $t$ ) contra ambas as variáveis dependentes de valor $\mathrm{Q}$ de Tobin $(\mathrm{Q})$ e valor da empresa sobre o ativo total (FIRMVSAT). Os resultados foram consistentes com os obtidos em 2000 e 1999, indicando que a separação dos cargos de diretor executivo e presidente do conselho é saudável para as companhias, conforme as recomendações do IBGC e CVM. As variáveis tamanho do conselho (TOT) e independência do conselho (INDEP) não apresentaram relação estatística significativa contra as variáveis de valor. De maneira geral, este foi o ano no qual os resultados se mostraram mais instáveis e menos significativos, provavelmente devido às turbulências de mercado ocorridas naquele período (crise da Rússia e eleição presidencial no Brasil). Os resultados dos principais modelos são apresentados na seqüência.

Quadro 34 - Relação entre a variável Q de Tobin $(Q)$ e as variáveis de governança em 1998

\begin{tabular}{crrrr}
\hline \hline Variável & Coeficiente & $\begin{array}{c}\text { Erro } \\
\text { Padrão }\end{array}$ & Estatística t & Prob. \\
\hline \hline C & 0.442377 & 0.196703 & 2.248963 & 0.0261 \\
DE & -0.053944 & 0.030139 & -1.789863 & $\mathbf{0 . 0 7 5 6}$ \\
INDEP & -0.004570 & 0.059435 & -0.076882 & 0.9388 \\
LOG(TOT) & -0.224941 & 0.224690 & -1.001119 & 0.3185 \\
LOG(TOT)^2 & 0.062654 & 0.063153 & 0.992097 & 0.3228 \\
SERV & 0.188560 & 0.026555 & 7.100654 & 0.0000 \\
DIVTSAT & 0.006661 & 0.000675 & 9.863646 & 0.0000 \\
& & & & \\
\hline \hline R-quadrado & 0.501125 & Critério de Schwarz & -0.980605 \\
R-quadrado ajustado & 0.480046 & Prob (estatística F) & 0.000000 \\
& & & \\
\hline \hline
\end{tabular}


Equação:

$==================$

$\mathrm{Q} 98=0.4423774721-\mathbf{0 . 0 5 3 9 4 4 4 0 2 2 2}{ }^{*} \mathrm{DE}-0.004569528731^{*}$ INDEP -

$0.2249413899^{*}$ LOG(TOT) $+0.06265439667^{\star}\left(\right.$ LOG $\left.(\text { TOT })^{\wedge} 2\right)+0.1885604685^{\star}$ SERV +

$0.006660689062^{*}$ DIVTSAT

Teste de Heterocedasticidade de White:

\begin{tabular}{llll}
\hline \hline \# Obs * R-quadrado & 28.36794 & Probabilidade & 0.244827
\end{tabular}

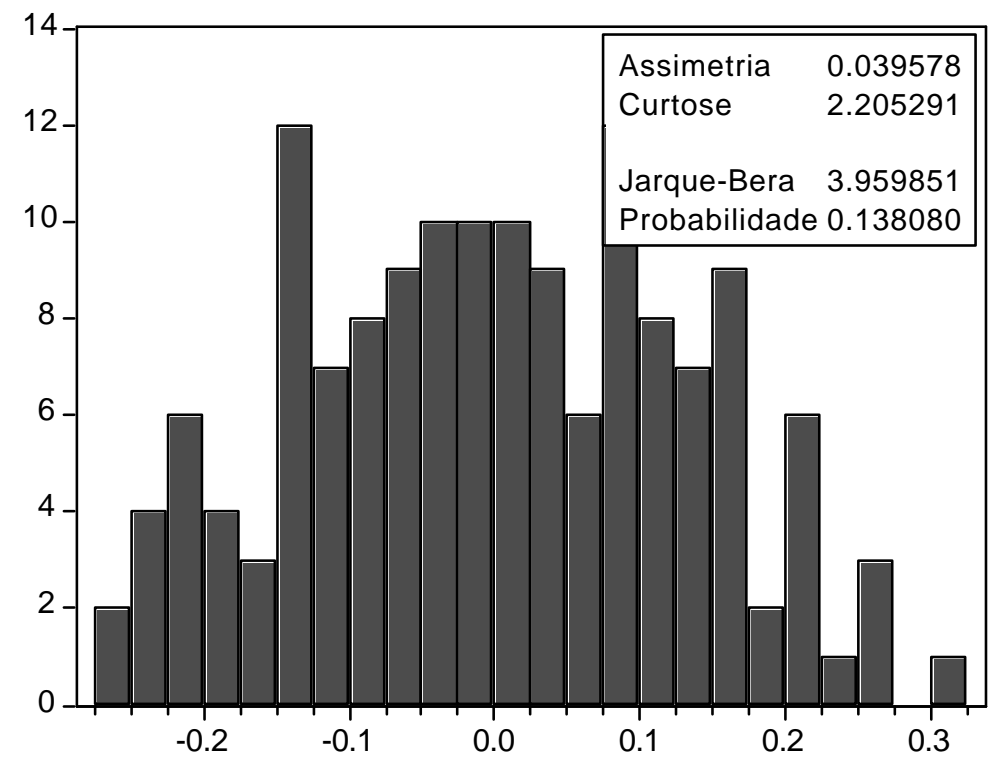

O teste de heterocedasticidade de White na regressão entre Q e as variáveis de governança em 1998 (probabilidade 0,24) não rejeitou a hipótese nula da homocedasticidade do modelo. O R-quadrado ajustado $(0,48)$ pode ser considerado razoável. O teste da normalidade dos resíduos de Jarque-Bera não rejeitou a hipótese nula de que os erros se distribuem como uma Normal (valor de probabilidade 0,13), confirmando a qualidade estatística do modelo. 
Quadro 35 - Relação entre a variável valor da empresa sobre ativo total (FIRMVSAT) e as variáveis de governança em 1998

\begin{tabular}{crrrr}
\hline \hline Variável & Coeficiente & $\begin{array}{c}\text { Erro } \\
\text { Padrão }\end{array}$ & Estatística t & Prob. \\
\hline \hline C & 0.228448 & 0.166342 & 1.373361 & 0.1718 \\
DE & -0.042147 & 0.024553 & -1.716569 & $\mathbf{0 . 0 8 8 2}$ \\
INDEP & -0.065909 & 0.049995 & -1.318314 & 0.1895 \\
LOG(TOT) & -0.058554 & 0.190803 & -0.306883 & 0.7594 \\
LOG(TOT)^2 & 0.020037 & 0.053332 & 0.375700 & 0.7077 \\
SERV & 0.177545 & 0.021818 & 8.137488 & 0.0000 \\
EBITSAT2 & 0.409029 & 0.118289 & 3.457885 & 0.0007 \\
DIVTSAT & 0.006926 & 0.000544 & 12.72523 & 0.0000 \\
& & & & \\
\hline \hline R-quadrado & 0.606759 & Critério de Schwarz & -1.313128 \\
R-quadrado ajustado & 0.587373 & Prob (estatística F) & 0.000000 \\
& & & & \\
\hline \hline
\end{tabular}

Equação:

$================$

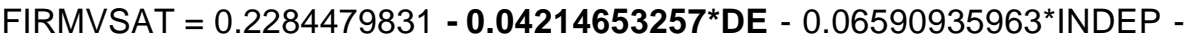

$0.05855421489^{*} \mathrm{LOG}(\mathrm{TOT})+0.02003691406^{*}\left(\mathrm{LOG}(\mathrm{TOT})^{\wedge} 2\right)+0.1775451734^{*} \mathrm{SERV}+$ $0.4090286515^{\star} \mathrm{EBITSAT2}+0.006926260156 *$ DIVTSAT

Teste de Heterocedasticidade de White:

\begin{tabular}{llll}
\hline \hline \# Obs * R-quadrado & 36.96086 & Probabilidade & 0.250437
\end{tabular}

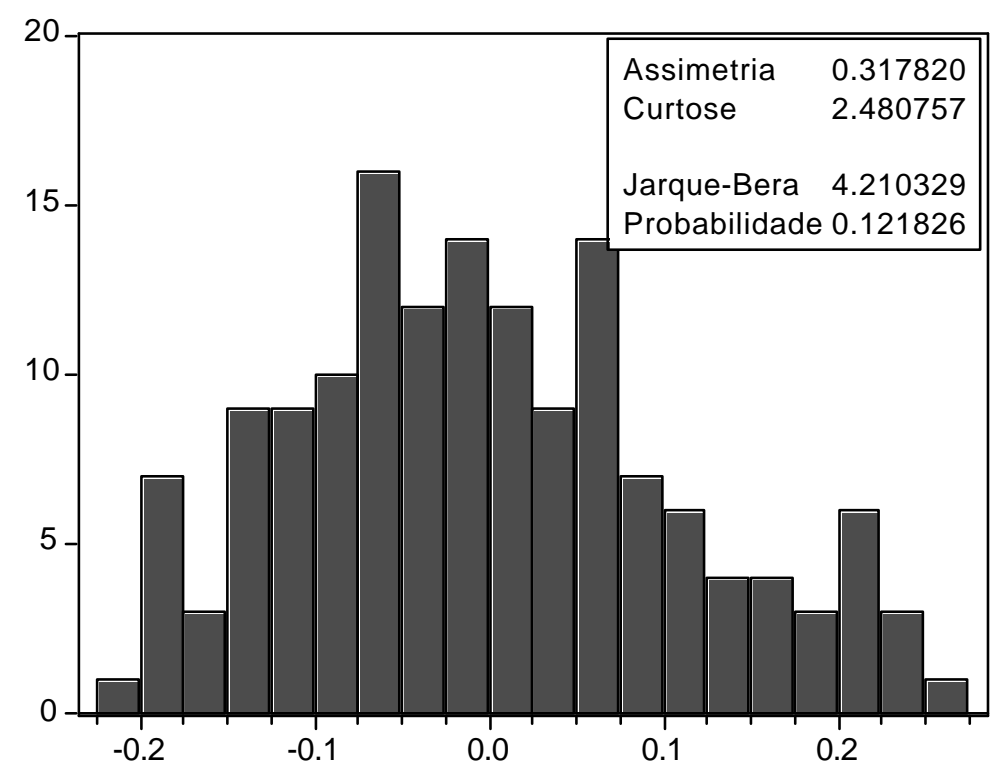

O teste de heterocedasticidade de White na regressão entre FIRMVSAT e as variáveis de governança em 1998 (probabilidade 0,25) não rejeitou a hipótese nula da homocedasticidade do modelo. O R-quadrado ajustado $(0,58)$ pode ser considerado bastante razoável. O teste da normalidade dos resíduos de Jarque-Bera não rejeitou a 
hipótese nula de que os erros se distribuem como uma Normal (valor de probabilidade 0,12), confirmando a qualidade estatística do modelo.

\subsubsection{Relação entre governança corporativa e desempenho em 1998}

Apenas um dos modelos construídos apresentou relação significativa das variáveis de governança contra as variáveis de desempenho em 1998. Nesse modelo, utilizando o lucro antes dos juros, impostos, depreciação e amortização (EBITSAT), a variável tamanho do conselho (TOT) apresentou uma relação quadrática negativa significante no nível de $5 \%$. Os sinais dos coeficientes foram consistentes com os obtidos em 2000 e 1999 (sinal do coeficiente linear positivo e sinal do coeficiente quadrático negativo), conforme as recomendações do IBGC e CVM da existência de uma faixa ótima para o tamanho do conselho. Foi construído um gráfico para visualizar a faixa ótima obtida para o tamanho do conselho, obtendo-se uma faixa ótima de quatro a seis membros, com o valor máximo de EBITSAT correspondendo a um conselho com 4,98 membros. Neste período, as variáveis diretor executivo como presidente do conselho (DE) e independência do conselho (INDEP) não apresentaram relação estatística significativa contra as variáveis de desempenho.

Quadro 36 - Relação entre o lucro antes dos juros, impostos, depreciação e amortização sobre o ativo (EBITSAT) e as variáveis de governança em 1998

\begin{tabular}{crrrr}
\hline \hline Variável & Coeficiente & $\begin{array}{c}\text { Erro } \\
\text { Padrão }\end{array}$ & Estatística t & Prob. \\
\hline \hline C & 0.003423 & 0.091456 & 0.037427 & 0.9702 \\
DE & -0.007281 & 0.015177 & -0.479738 & 0.6320 \\
INDEP & 0.023804 & 0.028836 & 0.825500 & 0.4103 \\
LOG(TOT) & 0.168317 & 0.102947 & 1.634985 & $\mathbf{0 . 1 0 4 0}$ \\
LOG(TOT)^2 & -0.052416 & 0.028424 & -1.844069 & $\mathbf{0 . 0 6 7 0}$ \\
DIVTSAT & -0.001608 & 0.000321 & -5.005050 & 0.0000 \\
SERV & 0.037786 & 0.013509 & 2.797116 & 0.0058 \\
& & & & \\
\hline \hline R-quadrado & 0.220532 & Critério de Schwarz & -2.217568 \\
R-quadrado ajustado & 0.192188 & Prob (estatística F) & 0.000000 \\
& & & & \\
\hline \hline
\end{tabular}

Equação:

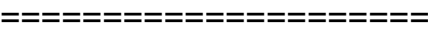

EBITSAT1 $=0.003422915959-0.007280927885^{\star} \mathrm{DE}+0.02380431244^{\star}$ INDEP +

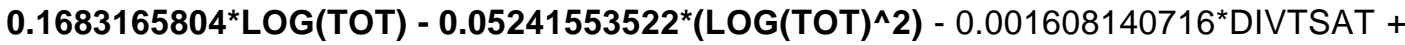
$0.03778593351 *$ SERV 
Teste de Heterocedasticidade de White:

\begin{tabular}{lccc}
\hline \hline \# Obs * R-quadrado & 27.81073 & Probabilidade & 0.268104 \\
\hline \hline
\end{tabular}

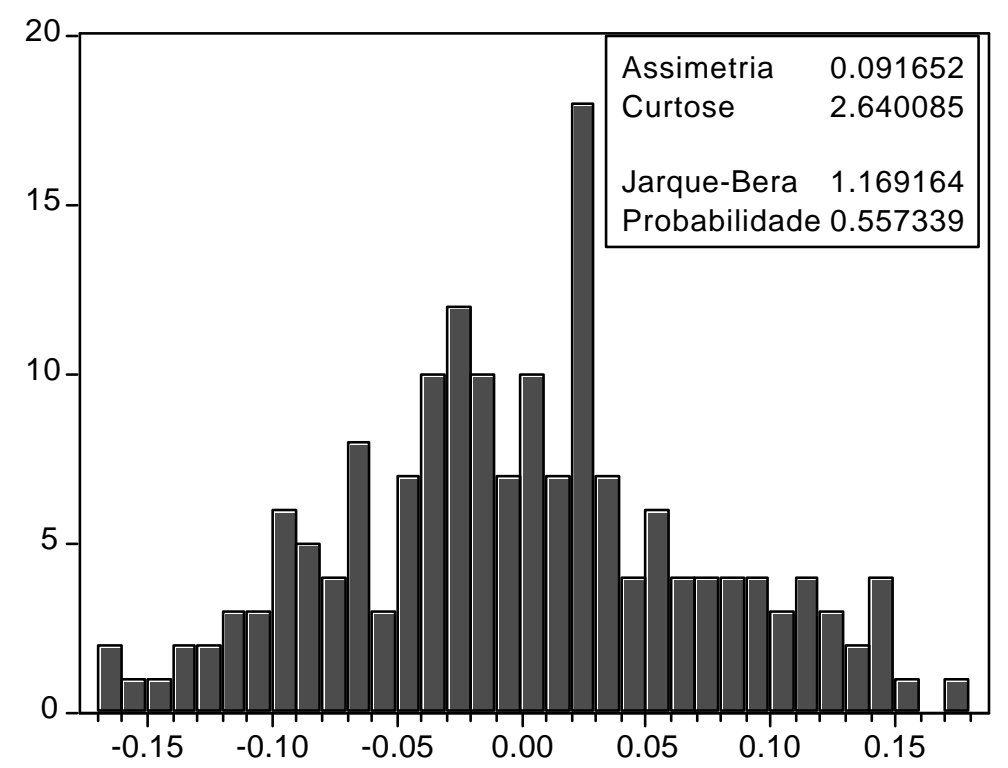

Figura 11 - Relação entre o lucro antes dos juros, impostos, depreciação e amortização sobre o ativo total (EBITSAT) e a variável tamanho do conselho (TOT) em 1998

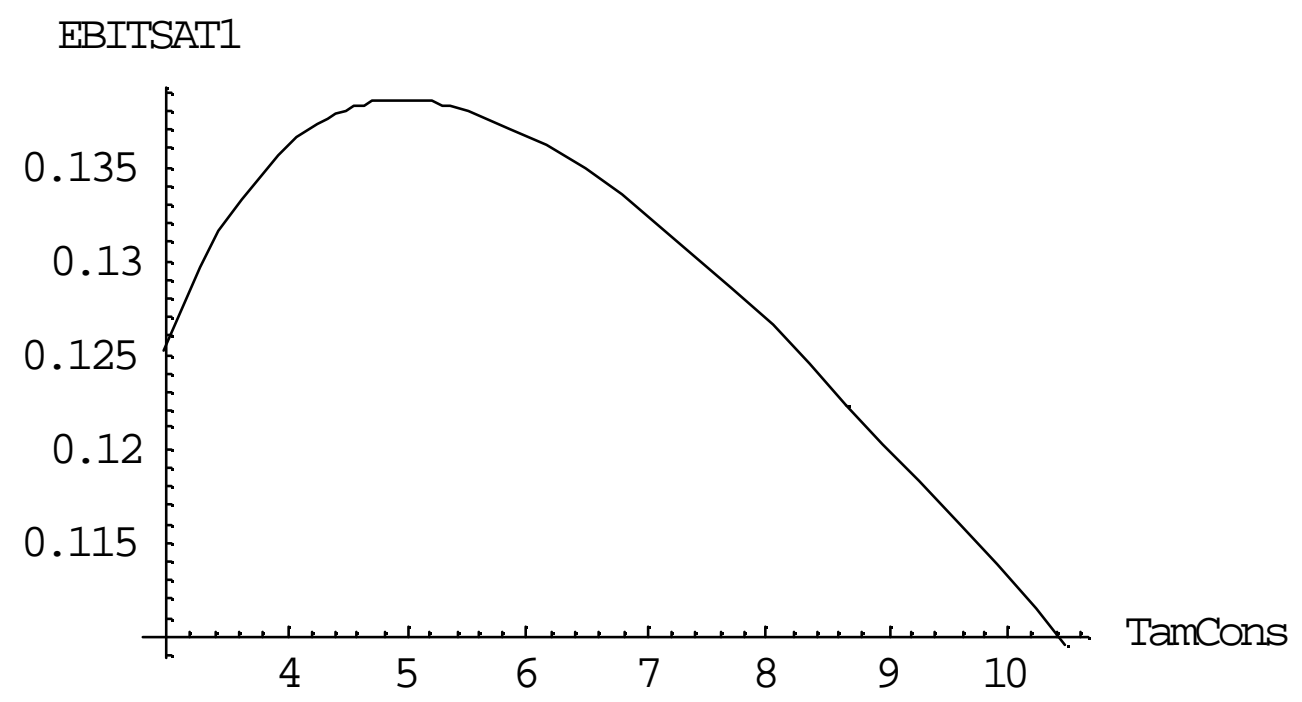

Tamanho ótimo do conselho para EBITSAT em 1998 - 4,98 membros

O teste de heterocedasticidade de White na regressão entre FIRMVSAT e as variáveis de governança em 1998 (probabilidade 0,27) não rejeitou a hipótese nula da homocedasticidade do modelo. O R-quadrado ajustado $(0,19)$ pode ser considerado 
baixo. O teste da normalidade dos resíduos de Jarque-Bera não rejeitou a hipótese nula de que os erros se distribuem como uma Normal (valor de probabilidade 0,55), confirmando a qualidade estatística do modelo. 


\subsection{Resumo dos Resultados da Pesquisa}

Os principais resultados obtidos com relação à significância estatística dos coeficientes são resumidos no quadro abaixo. O sinal entre parênteses representa o sinal do coeficiente obtido no modelo, enquanto o percentual representa o nível de significância estatística do coeficiente com base na estatística "t".

Quadro 37 - Resumo dos resultados da pesquisa

\begin{tabular}{|c|c|c|c|c|c|}
\hline & & láveis de & rnança ( & endent & \\
\hline & & DE & TOT & TOT $^{2}$ & INDEP \\
\hline e & Q00 & (-) $1 \%$ & & & \\
\hline हैं & FIRMVSAT00 & (-) $1 \%$ & (+) $10 \%$ & (-) $5 \%$ & \\
\hline$\ddot{\theta}$ & Q99 & (-) $15 \%$ & & & (+) $10 \%$ \\
\hline נֶ) & FIRMVSAT99 & (-) $15 \%$ & & & \\
\hline$\sum_{i}^{\infty}$ & Q98 & (-) $10 \%$ & & & \\
\hline$>$ & FIRMVSAT98 & (-) $10 \%$ & & & \\
\hline$\approx \approx z$ & RSAPR00 & (-) $10 \%$ & (+) $5 \%$ & (-) $5 \%$ & \\
\hline ¿ & EBITSAT99 & & (+) $5 \%$ & (-) $5 \%$ & \\
\hline$>\stackrel{0}{\circ}$ & EBITSAT98 & & (+) $10 \%$ & (-) $5 \%$ & \\
\hline 융 & $\begin{array}{l}\mathrm{H}_{\mathrm{o}} \text { - irrelevância } \\
\text { da governança } \\
\text { corporativa }\end{array}$ & & & & \\
\hline 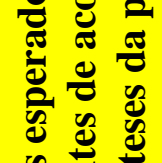 & $\begin{array}{l}\mathrm{H}_{1} \text { - confirmação } \\
\text { recomendações } \\
\text { do IBGC e CVM }\end{array}$ & - & + & - & + \\
\hline 昰 & $\begin{array}{l}\mathrm{H}_{2} \text { - sentido } \\
\text { oposto às } \\
\text { recomendações } \\
\text { do IBGC e CVM }\end{array}$ & + & - & + & - \\
\hline
\end{tabular}


Conforme o quadro acima, a variável diretor executivo como presidente do conselho (DE) foi a variável de governança que apresentou os resultados mais importantes da pesquisa. A variável DE apresentou uma correlação negativa significante estatisticamente nos níveis de $1 \%, 15 \%$ e $10 \%$ (valor da probabilidade associado à estatística $t$ ) contra ambas as variáveis dependentes de valor Q e FIRMVSAT nos anos de 2000, 1999 e 1998, respectivamente e significante a 10\% contra a variável de desempenho RSAPR em 2000. Os resultados se mostraram consistentes em todos os casos onde houve significância, principalmente em 2000, apresentando uma forte evidência de que as empresas que tiveram pessoas distintas ocupando os cargos de diretor executivo e presidente do conselho obtiveram, em média, maior valor de mercado. Este resultado corrobora a hipótese de que a adoção das recomendações do IBGC e CVM de separação dos cargos de diretor executivo e presidente do conselho é saudável para as empresas. A relação foi mais forte com as variáveis de valor Q de Tobin (Q) e valor da firma sobre o ativo total (FIRMVSAT) do que com as variáveis de desempenho, sugerindo que a separação dos cargos causa mais uma percepção positiva no mercado do que propriamente um melhor desempenho resultante das atividades operacionais da companhia. Como resultado, pode-se rejeitar a hipótese nula de que DE é irrelevante para o valor das empresas, assumindo como resultado a hipótese alternativa 1 da pesquisa. A relação entre DE e desempenho também foi consistente com a hipótese alternativa 1 , porém não tão forte estatisticamente.

A variável tamanho do conselho (TOT) apresentou uma relação quadrática negativa significante estatisticamente no nível de $10 \%$ (probabilidade da estatística $t$ ) contra a variável de valor FIRMVSAT em 2000 e no nível de 5\% contra as variáveis de desempenho RSAPR e EBITSAT em 2000, 1999 e 1998. Tendo em vista as recomendações do IBGC e da CVM (hipótese alternativa 1), era esperada a existência de uma faixa ótima para o tamanho do conselho. Isto seria refletido pela presença de um coeficiente linear (TOT) positivo e um coeficiente quadrático (TOT ${ }^{2}$ ) negativo, indicando uma concavidade para baixo da curva. Este foi o resultado obtido em todos os modelos com significância estatística contra as variáveis de valor e desempenho, sugerindo que é saudável para as empresas a adoção de um conselho com um número intermediário de membros, conforme as recomendações do IBGC e CVM. O gráfico da relação quadrática de TOT contra a variável de valor FIRMVSAT em 2000 indicou que as empresas com cinco a sete membros obtiveram, em média, maior valor no período. 
Os gráficos da relação quadrática de TOT contra as variáveis de desempenho em 2000, 1999 e 1998 indicaram que as empresas com quatro a oito membros alcançaram, em média, melhor desempenho. A relação foi mais forte com as variáveis de desempenho do que com as variáveis de valor, sugerindo que um conselho com tamanho intermediário é melhor para o desempenho financeiro da companhia mas isso não é tão percebido pelo mercado. Em resumo, pode-se rejeitar a hipótese nula da irrelevância de TOT em relação ao desempenho, assumindo como resultado a hipótese alternativa 1 para os modelos com significância. Entretanto, não se pode rejeitar a hipótese nula da irrelevância de TOT para o valor da empresa. Como outro resultado importante, constatou-se um relacionamento claramente não linear de TOT contra as variáveis dependentes, já que as regressões objetivando captar um relacionamento linear não se mostraram significantes.

A variável INDEP apresentou significância estatística (10\%) somente contra a variável de valor Q de Tobin em 1999, no sentido proposto pela hipótese alternativa 1 da pesquisa, sugerindo que as empresas com maior INDEP (proporção de conselheiros externos no conselho) apresentaram, em média, maior Q de Tobin em 1999. Entretanto, como apenas nesse modelo a variável apresentou significância e esta correlação se mostrou fraca estatisticamente, pode-se considerar a variável INDEP como irrelevante para o valor e desempenho corporativo, não rejeitando a hipótese nula da pesquisa para INDEP. 


\section{Considerações finais}

O objetivo principal da pesquisa foi verificar, estatisticamente, se existe uma relação significativa entre governança corporativa, valor da empresa e desempenho nas companhias abertas brasileiras, conforme as definições operacionais adotadas. Três variáveis de governança foram testadas contra as variáveis de desempenho e valor corporativo:

- presença de pessoas distintas ocupando os cargos de diretor executivo e presidente do conselho (DE);

- tamanho do Conselho de Administração (TOT);

- independência do Conselho de Administração (INDEP).

A variável diretor executivo como presidente do conselho (DE) foi a variável de governança que apresentou os resultados mais importantes da pesquisa. A variável DE apresentou uma correlação negativa significante estatisticamente no nível de $1 \%, 15 \%$ e $10 \%$ (valor da probabilidade associado à estatística $t$ ) contra ambas as variáveis dependentes de valor $Q$ de Tobin (Q) e valor da empresa sobre o ativo total (FIRMVSAT) nos anos de 2000, 1999 e 1998, respectivamente, e significante a 10\% contra variáveis de desempenho em 2000. Os resultados foram consistentes em todos os casos onde houve significância, principalmente em 2000, apresentando uma forte evidência de que, em média, as empresas que tiveram pessoas distintas ocupando os cargos de diretor executivo e presidente do conselho obtiveram maior valor de mercado. Este resultado corrobora a hipótese de que a adoção das recomendações do IBGC e CVM de separação dos cargos de diretor executivo e presidente do conselho é saudável para as empresas. A relação foi mais forte com as variáveis de valor do que com as variáveis de desempenho, sugerindo que a separação dos cargos causa mais uma percepção positiva no mercado do que propriamente um melhor desempenho resultante das atividades operacionais da companhia. A relação entre $\mathrm{DE}$ e as variáveis dependentes se mostrou mais forte no ano de 2000, indicando que o mercado pode recentemente ter se tornado mais sensível às recomendações dos códigos de governança e recompensado mais as empresas com separação de cargos. Além disso, a diminuição do percentual de empresas com unificação dos cargos de diretor executivo e presidente do conselho entre 1998 e 2000 (quadro 12) sugere que as próprias empresas também 
tenham percebido a necessidade da separação de cargos e estejam se adequando mais às recomendações dos códigos de governança.

A variável tamanho do conselho (TOT) também apresentou resultados consistentes e importantes. A variável TOT apresentou uma relação quadrática negativa significante estatisticamente no nível de $10 \%$ (probabilidade da estatística $t$ ) contra a variável de valor FIRMVSAT em 2000 e no nível de 5\% contra variáveis de desempenho em 2000, 1999 e 1998. Era esperada, a partir das recomendações do IBGC e da CVM, a existência de uma faixa ótima para o tamanho do conselho. Na regressão, isto seria refletido em um comportamento quadrático da variável TOT, com sinal do coeficiente linear positivo e com sinal do coeficiente quadrático negativo, indicando uma concavidade para baixo da curva. Este foi o resultado obtido em todos os modelos com significância estatística contra as variáveis de valor e desempenho, sugerindo que é saudável para as empresas a adoção de um conselho com um número intermediário de membros, conforme as recomendações do IBGC e CVM. O gráfico da relação quadrática de TOT contra a variável de valor FIRMVSAT em 2000 indicou que as empresas com cinco a sete membros obtiveram, em média, maior valor no período. Os gráficos da relação quadrática de TOT contra as variáveis de desempenho em 2000,1999 e 1998 indicaram que as empresas com quatro a oito membros alcançaram, em média, melhor desempenho. De maneira inversa aos resultados obtidos com a variável DE, a relação de TOT foi mais forte com as variáveis de desempenho do que com as variáveis de valor, sugerindo que um conselho com tamanho intermediário é melhor para o desempenho da companhia mas isso não é tão percebido pelo mercado. Como outro resultado importante, constatou-se um relacionamento claramente não linear contra as variáveis dependentes, já que as regressões objetivando captar um relacionamento linear não se mostraram significantes.

A variável independência do conselho (INDEP) apresentou significância estatística (10\%) somente contra a variável de valor Q de Tobin em 1999, indicando que as empresas com maior proporção de conselheiros externos obtiveram, em média, maior Q de Tobin em 1999. Entretanto, como apenas nesse modelo a variável apresentou significância e esta se mostrou fraca estatisticamente, não se pode considerar INDEP relevante para o valor ou desempenho corporativo. É importante ressaltar, todavia, que a definição operacional adotada para a independência do conselho, a única possível de ser 
obtida com base em dados secundários, fragilizou a análise da relação da independência do conselho com o desempenho e valor corporativo.

Duas variáveis de controle se mostraram importantes para o aprimoramento da qualidade estatística dos modelos e merecem ser destacadas para possível utilização em estudos posteriores:

- dívida de longo prazo / ativo total (DIVTSAT): por ser muito correlacionada com o valor e desempenho das empresas, se mostrou importante para todos os modelos construídos. Além disso, constatourse que as empresas nas quais os cargos de diretor executivo e presidente do conselho eram ocupados pela mesma pessoa se apresentaram menos endividadas. Esta constatação sugere que as empresas com um acionista controlador muito forte e que possuem maior probabilidade de ter o diretor executivo como presidente do conselho (como a maioria das empresas familiares) tendem a ser mais conservadoras na política de endividamento;

- setor de serviços de transporte, comunicação e eletricidade (SERV): Dentre todos os setores utilizados como variáveis de controle por meio de variáveis binárias, apenas o setor de serviços apresentou, eventualmente, relação significativa contra as variáveis dependentes, indicando que as empresas pertencentes a este setor obtiveram, em média, maior valor de mercado porém, paradoxalmente, pior desempenho.

Os resultados obtidos foram consistentes para todos os anos da pesquisa, porém mais instáveis e menos significantes no ano de 1998. A maior instabilidade dos resultados em 1998 ocorreu devido à grande variância dos resultados de valor e desempenho das empresas, provavelmente em razão das turbulências de mercado ocorridas naquele período (crise da Rússia e eleição presidencial no Brasil). Houve uma evolução anual da significância estatística das variáveis de governança de 1998 a 2000, principalmente contra as variáveis de valor, sugerindo uma percepção crescente do mercado com relação à importância da adequação das empresas ao recomendado como melhor estrutura de governança pelo IBGC e CVM. De maneira geral, as variáveis de valor tiveram relação mais forte com as de governança do que as variáveis de desempenho, sugerindo que a estrutura de governança afeta mais a percepção dos 
investidores e sua conseqüente avaliação de mercado do que o desempenho financeiro resultante das operações da companhia.

Em resumo, a relação entre governança e valor é diferente daquela entre governança e desempenho, sendo mais forte com o valor da empresa. Não é exagero afirmar que as empresas que têm pessoas distintas ocupando os cargos de diretor executivo e presidente do conselho são mais valorizadas, embora não se possa afirmar com convicção que tenham desempenho superior. O tamanho do conselho apresenta uma relação certamente não linear com valor e desempenho, sendo mais forte com o desempenho, sugerindo que as empresas com um número intermediário de conselheiros alcançam um melhor desempenho financeiro. A independência do conselho, conforme definida operacionalmente, não parece importante.

O presente trabalho pretende contribuir para as discussões qualitativas e quantitativas sobre a governança corporativa no Brasil. O tema, apesar da sua importância e crescente discussão, ainda possui literatura teórica muito escassa e quase inexistência de testes empíricos publicados no país. O trabalho não pretende esgotar a busca pela relação entre governança corporativa, valor da empresa e desempenho nas companhias abertas brasileiras, mas sim pretende suscitar interesse nessa linha de pesquisa. A corroboração (ou contestação) dos resultados obtidos nesta pesquisa por outros trabalhos pode aprimorar as recomendações sobre uma melhor estrutura de governança corporativa, caso haja alguma, para as empresas brasileiras, contribuindo, em última instância, para uma melhor gestão das empresas e para o desenvolvimento do mercado de capitais brasileiro.

Novos estudos podem ser feitos na busca da relação entre governança e valor ou desempenho corporativo, utilizando um horizonte de tempo maior ou distinto do utilizado nesta pesquisa. Ademais, testes estatísticos alternativos podem ser aplicados, bem como outras definiçõos operacionais para as variáveis. Como exemplos de testes estatísticos alternativos, poder-se-ia aplicar o modelo de equações simultâneas ou a análise de dados de painel. Como exemplo de outra definição operacional para as variáveis, poder-se-ia utilizar apenas o valor de mercado das ações ordinárias como variável dependente, dada a peculiaridade do mercado acionário brasileiro e visando 
observar a percepção dos minoritários ordinaristas em relação ao potencial de expropriação de riqueza pelo acionistas controlador.

Dada a amplitude da linha de pesquisa, outros estudos podem ser desenvolvidos, procurando responder questões como:

- existem mecanismos eficazes de governança corporativa que podem ser adotados por companhias inseridas em um ambiente com fraca proteção legal de forma a oferecer maior proteção aos investidores e reduzir o custo de captação de recursos? Quais são estes mecanismos de governança (ex. emissão de ADRs, adesão aos níveis diferenciados de governança da Bovespa)?

- quais são os fatores endógenos que afetam a governança corporativa e a proteção ao investidor em empresas sujeitas a um mesmo ambiente regulador e legal?

- como é possível avaliar a independência do Conselho de Administração em relação aos executivos e/ou acionistas controladores?

- como a composição do conselho afeta a execução de suas tarefas (remuneração dos executivos, demissão do diretor executivo, aquisição de outras empresas, etc.)?

- quais fatores afetam a composição do conselho e como estes fatores evoluem ao longo do tempo?

- qual a relação entre a mudança da composição do Conselho de Administração e o valor ou desempenho da empresa?

- qual a relação entre a presença de comitês do conselho e o valor ou desempenho da empresa?

- como pode ser modelada a relação endógena entre Conselho de Administração e desempenho, haja vista o dinamismo da relação de causalidade entre as variáveis?

Além destas questões, deve-se questionar se a própria busca por uma estrutura de governança que minimizasse os custos de agência é valida, pois as empresas poderiam simplesmente desenvolver estruturas ótimas de governança de acordo com 
suas circunstâncias (estágio de vida da empresa, posicionamento competitivo, setor de atuação).

Dentro da discussão sobre melhores estruturas de governança, é preciso comentar a crise de confiança dos investidores ocorrida em 2002 no mercado de capitais norte-americano, o mais sofisticado do mundo e tido como referência para os mercados menos desenvolvidos na adoção de melhores práticas de governança. Neste episódio, várias empresas com estruturas de governança adequadas às principais recomendações do mercado (como separação de cargos de diretor executivo e presidente do conselho, maioria de conselheiros independentes e tamanho adequado do conselho), prejudicaram gravemente seus investidores ao divulgar informações contábeis enganosas e omitir sérios conflitos de interesse de alguns dirigentes. Uma das lições que pode ser extraída dessa crise de confiança generalizada é a necessidade de desenvolver novos critérios para a avaliação da governança corporativa nas empresas, além da mera análise da estrutura estática do Conselho de Administração. Esses novos critérios poderiam contemplar, entre outras coisas, o entendimento da dinâmica da relação entre os principais agentes corporativos e a avaliação da eficácia dos processos de governança da alta administração.

Outra observação para aprimoramento dos estudos sobre governança corporativa no Brasil, resultante da fase de coleta dos dados, diz respeito à necessidade de que o órgão regulador do país exija das companhias abertas a divulgação de informações adicionais sobre sua estrutura de governança, entre as quais:

- a classificação dos conselheiros entre internos, externos e independentes, ao invés da mera divisão entre executivos e não executivos. Esta modificação faria com que as empresas identificassem os conselheiros profissionais (independentes) presentes nos seus conselhos;

- a divulgação do percentual de ações em posse dos executivos e conselheiros, mesmo que inferior a $5 \%$ do capital total;

- a divulgação da presença de comitês do conselho, com a identificação dos seus membros componentes e dos potenciais conflitos de interesse;

- a divulgação da forma de remuneração dos conselheiros e executivos, incluindo seus eventuais programas de opções de ações (stock options); 
- o esclarecimento de todos os laços financeiros dos conselheiros com a companhia (incluindo eventuais serviços de consultoria, doações da empresa para instituições da qual é participante, etc.).

A publicação das informações acima pelas empresas aumentaria o entendimento sobre a estrutura de governança das companhias e possibilitaria aos pesquisadores a realização de experiências com outras variáveis importantes, facilitando o desenvolvimento de estudos sobre governança corporativa no Brasil. 


\section{Referências Bibliográficas}

AGRAWAL, Anup, KNOEBER, Charles. Firm performance and mechanisms to control agency problems between managers and shareholders. Journal of Financial and Quantitative Analysis, v. 31, p. 377-397, September, 1996.

ALCHIAN, Armen., DEMSETZ, Harold. Production, information costs and economic organization. American Economic Review, v. 62, p. 777-795, 1972.

ALLEN, Franklin, GALE, Douglas. Comparing financial systems. 1. ed. Cambridge MA: MIT Press, cap. 1, 2000. 519p.

BARROS, Lucas Ayres Barreira de Campos, "Estrutura de Capital e Valor da Empresa no Contexto da Assimetria de Informações e Relações de Agência: Um Estudo Empírico", São Paulo, 2001. 182p. Dissertação (Mestrado) - Faculdade de Economia, Administração e Contabilidade da Universidade de São Paulo.

BARCA, Fabrizio. On Corporate governance in Italy: issues, facts and agency. Unpublished Working Paper, Bank of Italy, Rome, 1995.

BARNHART, Scott, ROSENSTEIN, Stuart. Board composition, managerial ownership and firm performance: an empirical analysis. The Financial Review, n. 33, p. 1-16, November, 1998.

BAYSINGER, B., BUTLER, H. Corporate governance and the board of directors: performance effects of changes in board composition. Journal of Law, Economics and Organization, v. 1, p. 101-124, 1985.

BHAGAT, Sanjai, BLACK, Bernard. The uncertain relationship between board composition and firm performance. Business Lawyer, v. 54, p. 921-963, 1999.

BHAGAT, Sanjai, BLACK, Bernard. Board independence and long term firm performance. Journal of Corporation Law (Forthcoming), v. 27, n.1, 2002.

BEBCHUK, Lucian. A rent protection theory of corporate ownership and control. NBER Working Paper No. W7203, Harvard Law School, Cambridge, MA, July, 1999.

BENNEDSEN, Morten, WOLFENSON, Daniel. The balance of power in closely held corporations. Journal of Financial Economics, v. 58, n. 1-2, p. 113-139, 2000. 
BERLE, Adolf Jr., MEANS, Gardiner. The modern corporation and private property. 1. ed. New York: Macmillan Publishing Company, cap. 1, 1932. 396p.

BRASIL, Lei n. 6.404, de 15 de dezembro de 1976. Dispõe sobre as Sociedades por Ações. Disponível em 〈http://www.cvm.gov.br>.

BRASIL, Lei n. 10.303, de 31 de outubro de 2001 Altera e acrescenta dispositivos na Lei $\mathrm{n}^{\circ}$ 6.404, de 15 de dezembro de 1976, que dispõe sobre as Sociedades por Ações, e na Lei $n^{\circ}$ 6.385, de 7 de dezembro de 1976, que dispõe sobre o mercado de valores mobiliários e cria a Comissão de Valores Mobiliários. Disponível em < http://www.cvm.gov.br>.

BROWN, William, MALONEY, Michael. Exit, voice, and the role of corporate directors: evidence from acquisition performance. Unpublished Working Paper, 1998.

BYRD, John, HICKMAN, Kent. Do outside directors monitor managers? evidence from tender offer bids. Journal of Financial Economics, v. 32, p.195-222, 1992.

CARLSSON, Rolf. Ownership and value creation: strategic corporate governance in the new economy. 1.ed. New York: John Wiley \& Sons, 2001. 307 p.

CHARKHAM, Jonathan. Keeping good company: a study of corporate governance in five countries. Oxford: Clarendon Press, cap. 5, 1994. 408p.

CHUNG, Kee, PRUITT. Stephen. A simple approximation of Tobin's Q. Financial Management, v.23, n. 3, p. 70-74, Autumn, 1994.

CLAESSENS, Stijn, DJANKOV, Simeon, FAN, Joseph, LANG, Larry. Expropriation of minority shareholders in East Asia. Unpublished Working Paper, The World Bank: Washington, DC, 1999.

COASE, Ronald. The nature of the firm. Economica, v.4, p. 386-405, 1937.

COASE, Ronald. The problem of social cost. Journal of Law and Economics, n. 3, p. 144, 1961.

CORE, John, HOLTHAUSEN, Robert, LARCKER, David. Corporate governance, chief executive officer compensation, and firm performance. Journal of Financial Economics, v. 51 p. 371-406, 1999. 
COTTER, James, SHIVDASANI, Anil, ZENNER, Marc. Do independent directors enhance target shareholder wealth during tender offers? Journal of Financial Economics, v. 43, p. 195-218, 1997.

DALTON, Dan, DAILY, Catherine. The board and financial performance: bigger is better. NACD Director's Monthly, p.1-5, August, 2000.

DEMSETZ, Harold. The structure of ownership and the theory of the firm. Journal of Law and Economics, v. 26, p. 375-393, June, 1983.

DEMSETZ, Harold, LEHN, Kennet. The structure of corporate ownership: causes and consequences. Journal of Political Economy, v. 93, p. 1155-1177, 1985.

EISENBERG, Theodore, SUNDGREN, Stefan, WELLS, Martin. Larger board size and decreasing firm value in small firms. Journal of Financial Economics v. 48, p. 35$54,1998$.

FAMA, Eugene, JENSEN, Michael. Separation of ownership and control. Journal of Law and Economics, v. 26, p. 301-327, June, 1983.

FAMA, Eugene. Agency problems and the theory of the firm, Journal of Political Economy, v. 88, n.2, p. 288-307, 1980.

FAMÁ, Rubens, BARROS, Lucas. $Q$ de Tobin e seu uso em finanças: aspectos metodológicos e conceituais. Caderno de Pesquisas em Administração, v.7, n. 4, outubro/dezembro, 2000.

FÜERST, Oren, KANG, Sok-Hyon. Corporate governance, expected operating performance, and pricing. Working in Progress, v.2.2, Yale School of Management, New Haven, CT, 2000.

GEDDES, Richard, VINOD, H. CEO age and outside directors: a hazard analysis. Review of Industrial Organization, n.12, p. 767-780, December, 1997.

GORTON, Gary, SCHMID, Frank. Universal banking and the performance of German firms. Journal of Financial Economics, v.58, p. 29-80, 2000.

GROSSMAN Sanford, Hart, Oliver. The cost and benefit of ownership: a theory of lateral and vertical integration. Journal of Political Economy, v. 94, p. 691-719, 1986. 
HAIR, Joseph, ANDERSON, Rolph, TATHAM, Ronald, BLACK, W. Multivariate data analysis. 5. ed., New Jersey: Prentice Hall, 1998. cap 1-3. 768p.

HANSMANN, Henry. The ownership of enterprise. 1. ed. Cambridge: Harvard University Press, cap. 4, 1996. 384p.

HARRIS, Milton, RAVIV, Arthur. The theory of capital structure. The Journal of Finance, v. XLVI, n.1, p.297-355, March, 1991.

HART, Oliver, HOLMSTROM, Bengt. The theory of contracts. In: Advances in Economic Theory, Fifth World Congress, ed. Tim Bewley, Cambridge University Press, 1987.

HART, Oliver, MOORE, John. Property rights and the nature of the firm. Journal of Political Economy, v. 98, n. 6, p.1119-1158, 1990.

HART, Oliver, MOORE, John. Debt and seniority: an analysis of the role of hard claims in constraining management. American Economic Review, v. 85, p. 567-585, 1995.

HART, Oliver. Firms, Contracts and Financial Structure. 1. ed. Oxford: Oxford University Press, cap. 1, 1995.

HERMALIN, Benjamin, WEISBACH, Michael. The effect of board composition and direct incentives on firm performance. Financial Management, v. 21, n.4, p. 101$112,1991$.

HERMALIN, Benjamin, WEISBACH, Michael. Endogenously chosen boards of directors and their monitoring of the CEO", American Economic Review, v. 88, n.1, p. $96-118,1998$.

HERMALIN, Benjamin, WEISBACH, Michael. Board of Directors as an endogenously determined institution: a survey of the economic literature. NBER Working Paper $n$. 8161, Cambridge, Massachusetts, 2001.

HOLMSTROM, Bengt, TIROLE, Jean. The theory of the firm. In: R. Schmalansee and R. Willings. (Org.) Handbook of Industrial Organization, Amsterdam: ed. Elsevier Science Pub. Co., vol.1, n.10, p. 61-133, 1989.

HOSHI, Takeo, KASHYAP, Anil, SCHARFSTEIN, David. Corporate structure, liquidity and investment: evidence from Japanese industrial groups. Quarterly Journal of Economics, n. 106, p. 33-60, February, 1991. 
IBGC. Pesquisa sobre governança corporativa. Novembro, 2001. Disponível em < http://www.ibgc.org.br>. Acesso em: 18 jul. 2002

JENSEN, Michael, MECKLING, William. Theory of the firm: managerial behavior, agency costs and ownership structure. Journal of Financial Economics, v.3, p. 305360, October, 1976.

JENSEN, Michael. Agency costs of free cash flow, corporate finance and takeovers. American Economic Review, v. 76, p. 323-329, May, 1986.

JENSEN, Michael. The modern industrial revolution, exit, and the failure of internal control systems. Journal of Finance, v. 48, p. 831-880, 1993.

JENSEN, Michael. A theory of the firm: governance, residual claims, and organizational forms. 1. ed. Harvard University Press, 2001. 320p.

KANG, Jun-Koo, STULZ, René. Do banking shocks affect borrowing firm performance? An analysis of the Japanese experience. Journal of Business, n. 73, p. 1-23, 2000.

KINI, Omesh, KRACAW, WILLIAM, Mian, Shehzad. Corporate takeovers, firm performance, and board composition. Journal of Corporate Finance, v. 1, p.383412, 1995.

LA PORTA, Rafael, SHLEIFER, Andrei, LOPEZ-DE-SILANES, Florencio, VISHNY, Robert. Law and finance. Journal of Political Economy, v. 106, p. 1113-1155, 1998.

LA PORTA, Rafael, SHLEIFER, Andrei, LOPEZ-DE-SILANES, Florencio, VISHNY, Robert. The quality of government. Journal of Law, Economics and Organization, n.15, p. 222-279, 1999a.

LA PORTA, Rafael, SHLEIFER, Andrei, LOPEZ-DE-SILANES, Florencio, VISHNY, Robert. Investor protection and corporate valuation. NBER Working Paper 7403Forthcoming in the Journal of Finance 2002, Cambridge MA, 1999b.

LA PORTA, Rafael, SHLEIFER, Andrei, LOPEZ-DE-SILANES, Florencio. Corporate ownership around the world. Journal of Finance, v. 54, p. 471-517, 1999c.

LA PORTA, Rafael, SHLEIFER, Andrei, LOPEZ-DE-SILANES, Florencio, VISHNY, Robert. Agency problems and dividend policies around the world. Journal of Finance, v. 55, p. 1-33, 2000a. 
LA PORTA, Rafael, SHLEIFER, Andrei, LOPEZ-DE-SILANES, Florencio, VISHNY, Robert. Investor protection and corporate governance. Journal of Financial Economics, v. 58, p. 3-27, October, 2000b.

LEAL, Ricardo, VALADARES, Sílvia, Ownership and control structure of Brazilian companies. Unpublished Working Paper. Disponível em < http://www.coppead.ufrj.br/ricardoleal/publications.html>. Acesso em: 18 jul. 2002

MACAVOY, Paul, CANTOR, Scott, PECK, Sarah. ALI proposals for increase control of the corporation by the Board of Directors: an economic analysis. In: Statement of the business roundtable on the American Law Institute's. Proposed "Principles of Corporate Governance and Structure: Restatement and Recommendations, exhibit C-1, February, 1983.

MARTINS, Gilberto de Andrade. Manual para elaboração de monografias $e$ dissertações. 2. ed. São Paulo: Atlas, 1994.116p.

MATSUSAKA, John G., Strong managers, weak owners: the political roots of American corporate finance by Mark J. Roe. The Independent Review - Journal of Political Economy. v.1, n.2, fall, 1996. Disponível em <http://www.independent.org/tii/content/pubs/review/TIR12.html>. Acesso em: 05 ago. 2002

MCKINSEY \& COMPANY, KORN/FERRY INTERNATIONAL. Panorama de Governança Corporativa no Brasil. São Paulo, 2001. 44p.

MONACO, Douglas Cláudio, "Estudo da Composição dos Conselhos de Administração e Instrumentos de Controle das Sociedades por Ações no Brasil", São Paulo, 2000. 177p. Dissertação (Mestrado) - Faculdade de Economia, Administração e Contabilidade da Universidade de São Paulo.

MORCK, Randall, SHLEIFER, Andrei, VISHNY, Robert. Management ownership and market valuation: an empirical analysis. Journal of Financial Economics, v. 20, p. 293-315, 1988.

MORCK, Randall, NAKAMURA, Masao. Banks and corporate control in Japan. Journal of Finance, v. 54, n.1, p. 319-340, February, 1999. 
PAGANO, Marco, PANETTA, Fabio, ZINGALES, Luigi. Why do companies go public? An empirical investigation. Journal of Finance, v.53, p. 27-64, February, 1998.

PATTERSON REPORT. The link between corporate governance \& performance - in collaboration with the conference board. Disponível em < http://www.thecorporatelibrary.com/link/>. Acesso em: 25 jul. 2002

PINDYCK, Robert, RUBINFELD, Daniel, Econometric Models and Economic Forecasts. 4ed. Nova York: Irvin/McGraw-Hill, cap. 1-7, 1998. 634p.

PORTER, Michael. Capital disadvantage: America's falling capital investment system. Harvard Business Review, n. 46, p. 65-72, September/October, 1992.

RAPPAPORT, Alfred. Creating shareholder value: a guide for managers and investors. 2. ed. New York: The Free Press, cap.1-3, 1998.205p.

ROE, Mark. Strong managers weak owners: the political roots of American corporate finance. 2. ed. Princeton, Nova Jersey: Princeton University Press, cap.1, 1994. $324 \mathrm{p}$.

SAVOIA, José Roberto. O processo de reformas da previdência no Brasil: uma visão dos fundos de pensão. Boletim de Previdência Complementar, v.1, n.10, maio/junho, 2001.

SHLEIFER, Andrei, VISHNY, Robert. Large shareholders and corporate control. Journal of Political Economy, n. 94, p. 461-488, 1986.

SHLEIFER, Andrei, VISHNY, Robert. Asurvey of corporate governance. Journal of Finance, v. 52, n. 2, p. 737-783, 1997.

STULZ, René. Managerial discretion and optimal financing policies. Journal of Financial Economics, v. 26, p. 3-26, 1990.

SUBRAHMANYAM, Vijaya, RANGAN, Nanda, ROSENSTEIN, Stuart. The role of outside directors in bank acquisitions. Financial Management, autumn, v.26, p. 2346, 1997.

TOBIN, James. Liquidity preferences as behavior towards risk. Review of Economic Studies, n. 65-86, February,1958. 
WAGNER, John, STIMPERT, Larry, FUBARA, Edward. Board composition and organizational performance: two studies of insider/outsider effects. Journal of Management Studies, n.35, p. 655-677, 1998.

WEISBACH, Michael. Outside directors and CEO turnover. Journal of Financial Economics, n. 20, p. 431-460, 1988.

WILLIAMSON, Oliver. The economic institutions of capitalism, New York: Free Press, cap. $1,1985.468$ p.

YERMACK, David. Higher market valuation of companies with a small board of Directors. Journal of Financial Economics, v. 40, n.3, p. 185-213, 1996.

ZINGALES, Luigi. Corporate governance. In: NEWMAN, Peter (editor). The New Palgrave Dictionary of Economics and the Law. New York, NY: Macmillan, 1998. 2210p. 


\subsection{Bibliografia Complementar}

ALCHIAN, Armen. Uncertainty, evolution and economic theory. Journal of Political Economy, v. 58, p. 211-221, June, 1950.

ANG, James, COLE, Rebel, LIN, James. Agency costs and ownership structure. Journal of Finance, v. 55, n. 1, p. 81-106, February, 2000.

ARCHER, Stephen, D'AMBROSIO, Charles. The theory of business finance: a book of readings. 3. ed. New York: The Macmillan Company, 1983.

BARNHART, Scott, MARR, Wayne, ROSENSTEIN, Stuart. Firm performance and board composition: some new evidence. Managerial \& Decision Economics, v. 15, n. 4, p. 329-340, 1994.

BALAKRISHNAN, Srinivasan, FOX, Isaac. Asset specificity, firm heterogeneity and capital structure. Strategic Management Journal, n. 9, p. 623-632, 1993.

BESLEY, David, KUH, Edwin, WELSCH, Roy. Regression diagnostics: identifying influential data and sources of collinearity. 1. ed. New York: John Wiley \& Sons, 1980. 320p.

BOA prática de gestão valoriza ações. Gazeta Mercantil, São Paulo, 19 dez. 2001.

COPELAND, Thomas, WESTON, Fred. Financial theory and corporate policy. 3a ed., New York: Addison-Wesley Publishing Company, 1988. 946 p.

COPELAND, Thomas, KOLLER, Tim, MURRIN, Jack. Valuation: measuring and managing the value of companies. 3 ed. New York: John Willey \& Sons Inc., 2000. $592 p$.

DAMODARAN, Aswath. Damodaran on valuation: security analysis for investment and corporate finance. 1 ed. New York: John Willey \& Sons Inc., 1994. 464p.

DANIELSON, Morris. A simple valuation model and growth expectations. Financial Analysts Journal, v. 54, n. 3, p. 50-57 March-June, 1998.

DENIS, David, SARIN, Atulya. Ownership and board structures in publicly traded corporations. Journal of Financial Economics, v. 52, p. 187-223, 1999. 
EDWARDS, Jeremy, FISHER, Klaus. Banks, finance and investment in west germany Since 1970. 1. ed. Cambridge, UK: Cambridge University Press, cap. 3, 1994.

FACCIO, Mara, LASFER, Ameziane. Managerial ownership, board structure and firm value: the UK evidence. Unpublished Working Paper, September, 1999.

GRINBLATT, Mark, TITMAN, Sheridan. Financial markets and corporate strategy. 1. ed. New York: R. D. Irwin e MacGraw Hill, 1998. 912 p.

HARRIS, Milton, RAVIV, Arthur. Corporate governance: voting rights and majority rules. Journal of Financial Economics, v. 20, p. 203-236, 1998.

KAPLAN, Steven, REISHUS, David. Outside directorships and corporate performance. Journal of Financial Economics, v. 27, p. 389-410, October, 1990.

KLEIN, April. Firm performance and board committee structure. Journal of Law and Economics, v. 41, p. 275-303, 1998.

KLEIN, April. An empirical analysis of the relation between board of directors' composition, firm performance, and the degree of CEO domination over the Board of Directors. Working Paper New York University, Stern School of Business, 1999.

KOENKER, Roger, BASSET, Gilbert. Regression Quantiles. Econometrica, v. 46, p. 33-50, 1978.

LINDENBERG, Eric, ROSS, Stephen. Tobin's q ratio and industrial organization. The Journal of Business, The Graduate School of Business of the University of Chicago, v. 54, n. 1, p. 1-32, January, 1981.

JENSEN, Michael, WARNER, Jerold. The distribution of power among corporate managers, shareholders, and directors. Journal of Financial Economics, v. 3, p. 305360, January-March, 1988.

JENSEN, Michael, MECKLING, William. The nature of man. Journal of Applied Corporate Finance, v. 7, n. 2, p. 4-19, Summer 1994.

JENSEN, Michael. Foundations of organizational strategy. Harvard University Press, 2001. $432 \mathrm{p}$.

JENSEN, Michael. A theory of the firm: governance, residual claims, and organizational forms. 1. ed. Harvard University Press, 2001. 320p. 
MCCONNEL, John, SERVAES, Henri. Additional evidence on equity ownership and corporate value. Journal of Financial Economics, v. 27, p. 595-612, 1990.

MODIGLIANI, Franco, Miller, Merton. The cost of capital, corporation finance, and the theory of investment. American Economic Review, v. 48, n. 3, p. 261-297, June 1958.

MODIGLIANI, Franco, MILLER, Merton. The cost of capital, corporation finance, and the theory of investment: reply. American Economic Review, v. 49, n. 4, p. 655-669, September 1959.

MODiGLIANI, Franco, MILLER, Merton. Corporate income taxes and the cost of capital: a correction. American Economic Review, v. 53, p. 433-443, June, 1963.

MORCK, Randall, SHLEIFER, Andrei, VISHNY, Robert. Management ownership and market valuation: an empirical analysis. Journal of Financial Economics, v. 20, p. 293-315, 1988.

NEW YORK UNIVERSITY. Damodaran on Valuation. Disponível em $<$ http//equity.stern.nyu.edu/ adamodar>. Acesso em: 20 out. 2001.

PORTER, Michael. Competitive strategy: techniques for analyzing industries and competitors. New York: The Free Press, 1980. 432p.

ROSENSTEIN, Stuart, WYATT, Jeffrey. Outside directors, board independence, and shareholder wealth. Journal of Financial Economics, v. 26, p. 175-191, 1990.

SIMON, Herbert. A behavioral model of rational choice. Quarterly Journal of Economics, v. 69, p. 99-118, February 1955.

STULZ, René. Managerial control of voting rights: financing policies and the market for corporate control. Journal of Financial Economics, v. 21, p. 25-54, 1988.

STERN, Joel, CHEW, Donald. The revolution in corporate finance. 3.ed. Cambridge: Blackwell, 1998. 520p.

STIGLER, G. The theory of price. 4. ed. New York: Prentice Hall College Division, January, 1997.

STULZ, René. Managerial control of voting rights: financing policies and the market for corporate control. Journal of Financial Economics, v. 20, p. 25-54, January/March,1988. 
WAGNER, John, STIMPERT, Larry, FUBARA, Edward. Board composition and organizational performance: two studies of insider/outsider effects. Journal of Management Studies, v. 35, p. 655-677, 1998.

WESTON, Fred, CHUNG, Kwang, SIU, Juan. Takeovers, restructuring and corporate governance. 2 ed. Prentice Hall, 1998. 564p.

WILLIAMSON, Oliver. Corporate finance and corporate governance. Journal of Finance, v. 43, p. 567-591, July, 1988.

WILLIAMSON, Oliver. The mechanisms of governance. Oxford: Oxford University Press, 1999. 439p.

ZINGALES, Luigi. Inside ownership and the decision to go public. Review of Economic Studies, v. 62, p. 425-448, 1995. 


\section{ANEXO A - CÓDIGOS DAS MELHORES PRÁTICAS UTILIZADOS NA PESQUISA}

\begin{tabular}{|c|c|c|c|c|}
\hline País & Título do Código & Instituição & Ano & Disponível em: \\
\hline Brasil & $\begin{array}{c}\text { Código das Melhores Práticas de } \\
\text { Governança Corporativa }\end{array}$ & IBGC & 2002 & $\underline{\text { www.ibgc.org.br }}$ \\
\hline Brasil & Cartilha de Governança Corporativa & CVM & 2002 & www.cvm.gov.br \\
\hline EUA & $\begin{array}{c}\text { Corporate Governance Core } \\
\text { Principles \& Guidelines }\end{array}$ & CALPERS & 1998 & $\begin{array}{c}\frac{\text { www.calpers- }}{\text { governance.org/princip }} \\
\text { les/domestic }\end{array}$ \\
\hline EUA & $\begin{array}{c}\text { Global Corporate Governance } \\
\text { Principles }\end{array}$ & CALPERS & 1999 & $\begin{array}{c}\frac{\text { www.calpers- }}{\text { governance.org/princip }} \\
\text { les/international/ }\end{array}$ \\
\hline EUA & $\begin{array}{c}\text { TIAA-CREF Policy Statement on } \\
\text { Corporate Governance }\end{array}$ & TIAA-CREF & 2000 & $\frac{\text { www.ecgi.de/codes } / \mathrm{me}}{\text { nu americas.htm }}$ \\
\hline EUA & Corporate Governance Policies & $\begin{array}{c}\text { Council of } \\
\text { Institutional } \\
\text { Investors (CII) }\end{array}$ & 2001 & $\frac{\text { www.ecgi.de/codes/me }}{\text { nu americas.htm }}$ \\
\hline EUA & $\begin{array}{c}\text { Statement on Corporate } \\
\text { Governance }\end{array}$ & $\begin{array}{l}\text { The Business } \\
\text { Roundtable }\end{array}$ & 1997 & $\frac{\text { www.ecgi.de/codes/me }}{\text { nu americas.htm }}$ \\
\hline $\begin{array}{l}\text { Reino } \\
\text { Unido }\end{array}$ & $\begin{array}{l}\text { Report of the Committee on the } \\
\text { Financial Aspects of Corporate } \\
\text { Governance - Cadbury Report }\end{array}$ & $\begin{array}{l}\text { London Stock } \\
\text { Exchange }\end{array}$ & 1992 & $\frac{\frac{\text { www.ecgi.de/codes/me }}{\text { nu europe.htm }}}{\text { no }}$ \\
\hline $\begin{array}{l}\text { Reino } \\
\text { Unido }\end{array}$ & Greenbury Recommendations & & 1995 & $\frac{\text { www.ecgi.de/codes/me }}{\text { nu europe.htm }}$ \\
\hline $\begin{array}{l}\text { Reino } \\
\text { Unido }\end{array}$ & $\begin{array}{c}\text { Committee on Corporate } \\
\text { Governance - Hampel Report }\end{array}$ & $\begin{array}{l}\text { London Stock } \\
\text { Exchange }\end{array}$ & 1998 & $\frac{\text { www.ecgi.de/codes/me }}{\text { nu europe.htm }}$ \\
\hline $\begin{array}{l}\text { Reino } \\
\text { Unido }\end{array}$ & $\begin{array}{l}\text { The Combined Code - Principles of } \\
\text { Good Governance and Code of Best } \\
\text { Practice }\end{array}$ & $\begin{array}{l}\text { London Stock } \\
\text { Exchange }\end{array}$ & 2000 & $\frac{\frac{\text { www.ecgi.de/codes/me }}{\text { nu europe.htm }}}{\text { nut }}$ \\
\hline $\begin{array}{l}\text { União } \\
\text { Européia }\end{array}$ & $\begin{array}{c}\text { Euroshareholders Corporate } \\
\text { Governance Guidelines }\end{array}$ & $\begin{array}{c}\text { Eurosharehold } \\
\text { ers }\end{array}$ & 2000 & $\frac{\text { www.ecgi.de/codes/me }}{\text { nu europe.htm }}$ \\
\hline OECD & $\begin{array}{l}\text { OECD Principles of Corporate } \\
\text { Governance } \\
\end{array}$ & OECD & 1999 & $\underline{\text { www.oecd.org }}$ \\
\hline Alemanha & $\begin{array}{c}\text { Code of Best Practice for German } \\
\text { Corporate Governance }\end{array}$ & $\begin{array}{c}\text { German Panel } \\
\text { on Corporate } \\
\text { Governance }\end{array}$ & 2000 & $\frac{\text { www.ecgi.de/codes/me }}{\text { nu europe.htm }}$ \\
\hline Alemanha & $\begin{array}{l}\text { German Code of Corporate } \\
\text { Governance }\end{array}$ & $\begin{array}{l}\text { Berlin initiative } \\
\text { Group }\end{array}$ & 2000 & $\frac{\text { www.ecgi.de/codes/me }}{\text { nu europe.htm }}$ \\
\hline França & $\begin{array}{l}\text { Recommendations of the } \\
\text { Committee on Corporate } \\
\text { Governance - Vienot Report }\end{array}$ & $\begin{array}{c}\text { Association } \\
\text { Francaise Des } \\
\text { Entreprises } \\
\text { Privers - AFEP }\end{array}$ & 1999 & $\frac{\text { www.ecgi.de/codes/me }}{\text { nu europe.htm }}$ \\
\hline Japão & $\begin{array}{l}\text { Corporate Governance Principles - } \\
\text { A Japanese View (Interim Report) }\end{array}$ & $\begin{array}{l}\text { Corporate } \\
\text { Governance } \\
\text { Forum of } \\
\text { Japan }\end{array}$ & 1997 & $\frac{\underline{\text { www.ecgi.org } / \text { codes } / \mathrm{m}}}{\text { enu asia pacific.htm }}$ \\
\hline
\end{tabular}




\section{ANEXO B - GLOSSÁRIO DOS TERMOS UTILIZADOS NA PESQUISA}

Conselheiros Externos - são os conselheiros que não trabalham na empresa, mas não são independentes.

Conselheiros Independentes - são os conselheiros que:

- não possuem qualquer vínculo com a empresa, exceto eventual participação de capital;

- não são cônjuges ou parentes até segundo grau de algum diretor ou gerente da empresa;

- não foram indicados pelo acionista controlador para representar exclusivamente seus interesses;

- não oferecem serviço ou produto à empresa;

- não recebem outra remuneração da empresa além dos honorários de conselheiro e eventuais dividendos (se for também proprietário);

- não são empregados de entidade que esteja oferecendo serviço ou produto à empresa;

- não são empregados de alguma empresa na qual o diretor executivo atue como conselheiro;

- não são afiliados a organizações sem fins lucrativos que recebem contribuições significativas da empresa;

- não foram empregados da empresa ou de alguma de suas subsidiárias.

Conselheiros Internos - são os conselheiros que são diretores ou empregados da empresa.

Códigos das Melhores Práticas de Governança Corporativa - são documentos criados por agentes de mercado (investidores institucionais, organismos internacionais, bolsas de valores, associações) que estabelecem regras ou diretrizes para as empresas de forma a aprimorarem sua governança corporativa.

Diretor Executivo - é o principal executivo da companhia, geralmente chamado de CEO (Chief Executive Officer) no exterior.

Gestores - são os altos executivos da companhia. No Brasil, são definidos legalmente como os diretores da empresa. 


\section{ANEXO C - TEXTOS ORIGINAIS DO IBGC E CVM NOS ITENS SELECIONADOS PARA DEFINIÇÃO DA "MELHOR ESTRUTURA DE GOVERNANÇA CORPORATIVA"}

\section{Instituto Brasileiro de Governança Corporativa (IBGC) - Código das \\ Melhores Práticas de Governança Corporativa}

\subsection{Tamanho}

O tamanho do Conselho de Administração deve variar em função do perfil da empresa, entre 5 e 9 membros.

\subsection{Conselheiros internos e externos}

O conselho fiscaliza a gestão dos diretores. Fiscalizar a si mesmo é uma situação típica de conflito de interesses. Por conseguinte, deve-se evitar acumulação de cargos entre conselheiros e diretores.

\subsection{Presidente do conselho e presidente da diretoria}

Deve-se buscar a separação dos cargos do presidente do conselho e do presidente da diretoria (executivo principal - CEO).

\section{Cartilha da CVM - Recomendações da CVM sobre governança corporativa}

II.1 O Conselho de Administração deve ter de cinco a nove membros tecnicamente qualificados, com pelo menos dois membros com experiência em finanças e responsabilidade de acompanhar mais detalhadamente as práticas contábeis adotadas. $\mathbf{O}$ conselho deve ter $\mathbf{o}$ maior número possível de membros independentes da administração da companhia. Para companhias com controle compartilhado, pode se justificar um número superior a nove membros. O mandato de todos os conselheiros deve ser unificado, com prazo de gestão de um ano, permitida a reeleição.

II.4 Os cargos de presidente do Conselho de Administração e presidente da diretoria (executivo principal) devem ser exercidos por pessoas diferentes. 